\title{
Ecological, social and economic determinants in cocoa production systems in southern Cameroon
}

\author{
Dissertation \\ to obtain the Ph. D. degree \\ in the International Ph. D. Program for Agricultural Sciences in Goettingen \\ (IPAG) \\ at the Faculty of Agricultural Sciences, \\ Georg-August-University Göttingen, Germany
}

presented by

Bisseleua Daghela Hervé Bertin

born in Bafang, Cameroon

Göttingen, September 2007 
1. Name of supervisor:

2. Name of co-supervisor:

Date of dissertation:
Prof. Dr. Stefan Vidal

Prof. Dr. Teja Tscharntke

November 15, 2007 


\section{To my entire Family "Good Things come to those who wait"}




\section{CHAPTER 1}

Plant biodiversity and vegetation structure in traditional cocoa forest gardens in southern Cameroon under different management Hervé D. B. Bisseleua and Stefan Vidal

\section{CHAPTER 2}

Perception of cocoa agroforest management by farmers after introducing IPM in Farmer's organizations in southern Cameroon Hervé D. B. Bisseleua and Stefan Vidal

\section{CHAPTER 3}

Women Perception of traditional cocoa forest garden management in southern Cameroon

Hervé D. B. Bisseleua and Stefan Vidal

CHAPTER 4

Impact of Cocoa farmers' management practices on the incidence of pests, diseases and yield in traditional cocoa forest gardens in southern Cameroon

Hervé D. B. Bisseleua and Stefan Vidal

\section{CHAPTER 5}

Sampling and temporal distribution of Salhbergella singularis

(Haglung) (Hemiptera: Miridae) on cocoa

Hervé D. B. Bisseleua and Stefan Vidal 
Mutually exclusive interactions between a mirid bug and a plant pathogen on Cocoa trees

Hervé D. B. Bisseleua and Stefan Vidal

\section{CHAPTER 7}

Impact of ants on black pod disease incidence in cocoa plantations in the humid Rainforest area of Cameroon

Hervé D. B. Bisseleua and Stefan Vidal

CHAPTER 8

Predatory activity of ants in cocoa plantations under different management regimes: The insurance hypothesis

Hervé D. B. Bisseleua and Stefan Vidal

CHAPTER 9

180

Biodiversity, yield, net income and vegetation structure in traditional cocoa forest gardens in southern Cameroon

Hervé D. B. Bisseleua and Stefan Vidal 


\section{Summary}

More diversified and species rich systems relate to functional consequences, which in turn will influence ecosystem processes, reducing outbreaks. This has been shown for landscape management practices and for intercropping systems. However, the role of biodiversity in biological control still remains uncertain. I studied the relationship between biodiversity and biological control of cocoa pests and diseases, the social implications and the associated cost-benefit ratios under different management regimes in 17 traditional cocoa forest gardens (TFGs) in southern Cameroon. I hypothesized that increasing biodiversity, measured as plant and ant species richness, will enhance biological control of the main cocoa pests and diseases and will thus contribute to increase in farmer incomes and sustainability of TFGs. The results of this study aim to understand the ecological, social and economic determinants in cocoa production systems in southern Cameroon.

In a survey of 400 cocoa farmers, they described a complex situation ranging from biological, institutional to socio-economic production constraints affecting their cocoabased livelihoods. The survey also revealed that with rising land values, women have created new access and new rights to land.

The floristic surveys showed that land-use management as practiced in traditional cocoa forest gardens in southern Cameroon, following a gradient of intensification from extensive cocoa forest gardens with high floristic diversity to intensive ones, strongly impacts plant diversity, above ground plant biomass and to some extend carbon storage, respectively, with possible negative consequences on biodiversity. Significant differences were found associated with the different managements with regard to species richness and abundance of ants. Ecosystem functioning showed a significant responses to shade cover reductions in TFGs for herbivory.

Biotic interactions were studied by looking at the population dynamics of mirid bugs: Salhbergella singularis (SS), the interactions between SS and black pod disease caused by Phytophthora megakarya (BPD), predation by ants and interactions between ants and

BPD. Based on my surveys, I have developed and recommend a sequential sampling plan based on counts of mirid bugs. I observed that the interaction between the mirid bugs and black pod disease was found to be mutually exclusive in space and time independent of 
management regimes. These findings release SS from the popular notion of being a vector of BPD. Our results also support the insurance hypothesis and suggest an important role for ants in controlling pest and disease outbreaks in TFGs. Moreover, I provide evidence for the first time that ants, although generally regarded as beneficial, do contribute to the incidence of black pod disease given a low diversity of ant species on cocoa trees. However, if ant communities become more diverse and niche structure more restricted on these trees, incidences of BPD significantly decrease.

My findings result in a set of non-linear relationships between yield and ant species richness in TFGs. I provide a direct measurable assessment of the biodiversity-net income relationships in cocoa. My model describes a concave relationship between biodiversity and profitability and highlights the importance of the Management Index (MI) in certification procedures. Economic incentives are required to prevent further intensification of cacao production systems beyond ecologically acceptable shade cover percentages. Finally, my study identifies potential determinants that researchers and policy makers need to focus their attention to, to facilitate the development of coherent innovations in cocoa production. 


\section{Introduction}

"The clearance of pristine natural forest habitats for commodities production systems remains one of the greatest threats to global biodiversity. However, the level of management can play an important part in determining the resulting loss of biodiversity" Paul F. Donald, 2004

The "chocolate tree" Theobroma cacao (Malvaceae) originated in South America's Amazon basin and has been part of human culture since 2000 years. It is a world economic crop cultivated in the humid tropics of West-Africa (Côte d'Ivoire, Cameroon, Ghana, Nigeria, Liberia, Sierra-Leone, Togo and Sao Tome), South-East Asia Indonesia, Malaysia), South-America (Brazil, Colombia, Costa Rica, Ecuador, Mexico and Peru) and the Caribbean (Belize, Trinidad and Tobago, Dominican Republic) by 40 to 50 millions smallholder farmers totaling a world annual production of 3.6 millions tones with a market value of US\$ 7 billion (ICCO 2005, Lass 2004). Seventy two percent of the world production is supplied by West-Africa (ICCO 2005) where cocoa is essentially a smallholder crop, cultivated on about 5.2 million ha of land ranging in size from 0.5 to 7 ha (Clay 2004).

Cocoa was introduced in Southern and Eastern Cameroon from Sao Tome and Principe in the nineteenth century (Nya Ngatchou, 1981) and in Western Cameroon in 1886 by the German colonial administration. In the mid 1920s, cocoa cultivation has shifted from plantations owned by foreign to indigenous growers who are mainly smallholders (Gockowski and Dury 1999). About $80 \%$ of the production is in three provinces namely the South West (35\%), the Centre (28\%) and the South (16\%) and accounts for around $6 \%$ of Cameroon's exports, and is of crucial importance for their economy. An estimated 450,000 rural households (more than a third of the total number of rural households) earned the larger part of their cash income from cocoa (Sonwa et al. 2001, Gockowski and Ndoumbe 2004). The total acreage under cocoa cultivation in Cameroon was roughly about 420,000 hectares with current production level averages 168,000 metric tonnes per 
annum (ICCO 2005) and aims of raising this to 300,000 metric tonnes by the year 2010 . However, despite the economic importance of cocoa and farmers' sustained interest in production, yields of cocoa continue to be lower averaging $300 \mathrm{~kg} / \mathrm{ha}$. Reasons for the low productivity are the ageing of the trees (mainly in Southern Cameroon where $40 \%$ of cocoa trees were planted before 1960), poor farm maintenance practices, planting of lowyielding varieties, ravages caused by pests' such as mirids (Salhbergella singularis H.)(Mpé, 2002), diseases (Phytophthora species: P. megakarya; causing 80-90\% losses without chemical control) (Gregory et al., 1985; Nyasse, 1992) and poor soil fertility caused by prolonged cultivation on farmlands. Other causes include removal of agricultural subsidies, increased costs of chemicals and spraying equipments and the low prices paid to Cameroonian cocoa farmers (Sonwa et al., 2002).

The genetic diversity (origin and type of material grown) of cultivated cocoa remains largely unknown. However, it is suggested to be constituted mainly of traditional varieties, notably the so-called "German Cocoa" which is the result of natural hybridization between Trinitario and Amelonado types (first populations introduced in the country); and populations introduced from Ghana (Upper Amazon origin) (Efombagn et al. 2006); and hybrid varieties, resulting from the locally selected Trinitario types and also introduced Upper Amazon clones (UPA and T-clones). Smallholder cocoa farmers are presently not very satisfied with the hybrid varieties, because of tree mortality ("dieback" of which the cause is not well identified) and the reported higher susceptibility to diseases and pests. Therefore, in general, the farmers harvest cocoa pods on their grown trees to obtain seeds for new plantings (farm extension or replacement of dead trees).

In southern Cameroon, cocoa agroforests are cultivated in association with forest and exotic tree species on land of about $0.5-4$ ha, resulting primarily from the clearing of some large forest trees in either secondary or primary forests. Other large trees are left during the establishment of the plantation and crops such as banana and plantain are used as shade for seedlings. The forest seed banks promote the regeneration of some native trees species while useful exotic and local tree species are planted by the farmers. In general, this results in a multi-strata and multi-species agroforest whose species reflect the need of local people (Sonwa et al. 2001; Schroth et al. 2004 and Perfecto et al. 2005). 
These type of agroforestry systems, combining a mixture of natural forest tree species such as fruit tree species, timber, semi-cultivated woody plants (Elaeis guineensis) and cultivated plants (cocoa and bananas), present higher levels of plant diversity (overall richness of 206 tree species)(Sonwa et al. 2007) as compared to other cocoa production region in West-Africa and Latin America. Such agroforests systems have become part of complex traditional forest gardens management systems (TFGs) (Guyer 1984, Laird et al. 2007, Sonwa et al. 2007). However, in comparison with other land-uses, TFGs with diverse and structurally complex shade canopies are among the agricultural land uses that are most likely to conserve a significant portion of the original forest biodiversity (Rice and Greenberg 2000, Zapfack et al. 2002, Bobo et al. 2007, Laird et al. 2007).

Considerable scientific and public attention has been dedicated to shade coffee systems for their ability to maintain biodiversity (Perfecto et al. 1996, Moguel and Toledo 1999, Perfecto et al. 2005, Philpott et al. 2006). However, only few papers have reported the role of biodiversity within cocoa agroforestry systems (Faria et al. 2006, Delabie et al. 2007, Sonwa et al. 2007). The current trend of simplifying the shade canopies of TFGs and converting them into more intensive systems without any shade or to other agricultural land uses (such as annual crops that are generally less compatible with biodiversity conservation) has similarly received little attention despite the potential negative impacts on the biodiversity of the tropical forest landscape where cocoa is grown. Research has provided evidence that cocoa agroforests with a high floristic and structural diversity may help in regulating pests and diseases and allow for efficient adaptation to changing ecological and socio-economic conditions (Schroth et al. 2004, Dahlquist et al. 2007, Delabie et al. 2007, Merijn et al. 2007).

Recently, more and more research has been conducted on the health and nutritional attributes of cocoa and chocolate in preventing cancer (Lee et al. 2003), diabetes and stress (ICCO 2005), hypertension (Taubert el al. 2007), heart disease and stroke (Mink et al. 2007) or stimulating brain activity (Bayard et al. 2007),. Based on current findings on the benefit of chocolate, it is expected that the world chocolate demand will more than double by 2050 (Donald 2004). Such incentives associated with the current trend to reduce or eliminate shade cover in cocoa and the international price recovery (ICCO 2005) suggests that cocoa production in southern Cameroon is likely to remain a major 
contribution to deforestation at the forest-agriculture interface where much pristine forest remains.

However, since the late $1980 \mathrm{~s}$, the cacao sector has been subjected to several major economic shocks that have led to new institutional and organizational frameworks in southern Cameroon (Duguma et al. 2001, Sonwa et al. 2002). The drastic fall in world prices of cacao and other commodities during this time period contributed to substantial domestic economic problems. Cacao farmers responded to the crisis by increasing their activity in food crop production to compensate for the lost income (Sonwa 2004). This in turn led to a very significant increase in forest clearing with its entailed profound negative environmental, economic and political consequences, respectively.

There are very few studies on the trade-offs between biodiversity loss and agricultural intensification (Perfecto et al. 2005, Gordon et al. 2007 and Steffan-Dewenter et al. 2007). Two opposing models are proposed concerning the value of intensification for conservation; either wildlife-friendly farming on the cost of agricultural yields (Philpott and Dietsch 2003, Dietsch et al. 2004) or land sparing by agricultural intensification to minimize the demand for natural habitat (O’Brien and Kinnaird 2003, Rappole et al. 2003a,b). However, Green et al. (2005) showed that the best type of farming for species persistence depends on the relationship between species richness and yields.

Due to the sociopolitical and economic dimensions of cocoa, policy makers and smallholder cocoa farmers need to be familiar with the role of biodiversity in cocoa farming and the cost-benefit ratio associated (Donald 2004, Steffan-Dewenter 2007, Franzen and Mudler 2007). Greenberg (1998) argues that the conservation of shadegrown cocoa plantations needs to entail financial incentives for the grower and ecosystem services for the consumer. The incentives could be derived in four ways: (1) if the market is willing to purchase more environmentally-friendly products; (2) if the financial benefits of the ecological services arising from shade production is acknowledged; (3) if the income derived from non-crop plants is valued; and (4) if there are national or international programs to subsidize low-intensity management. Examples of synergistic interactions between biodiversity and profitability have been found in many agroecosystems, and include the control of pest populations by a diverse community of 
predatory, or "beneficial", arthropods, increased pollination services to crop plants by native pollinating insects, increased soil nitrogen availability by the $\mathrm{N}$-fixing microbes of leguminous plants and increased carbon sequestration (Kotto-Same et al. 1993, Vandermeer 1995, Pimentel et al. 1997, Romero-Alvarado et al. 2002, Soto-Pinto et al. 2002, Klein et al. 2003a,b Perfecto et al. 2004, Philpott et al. 2006, Steffan-Dewenter et al. 2007, Delabie et al. 2007).

Steffan-Dewenter et al. (2007) provided evidence for the complexity of the relationship between biodiversity and profitability in cocoa agroecosystems in Indonesia. This relationship may include synergies as well as trade-offs. If the two parameters are well understood in cocoa, land-use management, agronomic practices and policies can be planned to generate significant returns for smallholder cocoa farmers and help to implement efficient and successful tropical rainforests biodiversity conservation programs. 


\section{Objectives}

We used traditional cocoa forest gardens in southern Cameroon to evaluate the ecological and social consequences of agricultural intensification on species richness and ecosystem functions and the following economic implications. Specifically we addressed:

1. the impact of land-use management intensity on structural and functional biodiversity of TFGs in southern Cameroon. This impact was evaluated by analyzing species richness, vegetation structure, carbon sequestration and above ground biomass

2. farmers' socio-economic background and farming practices with focus on gaining an understanding farmers' awareness of the ecological and economic changes brought about as a result of liberalization of the cocoa sector

3. the mechanisms regulating gender access to productive assets and modern technology and its implication on productivity and income

4. pattern and processes regulating biotic interactions in TFGs by studying the population dynamics of mirid bugs, the epidemiology of black pod disease and analysing the interactions between the two damaging agents. Moreover, we quantified herbivory in general.

5. the functional and economic implications of maintaining biodiversity in traditional cocoa forest gardens. 


\title{
Plant biodiversity and vegetation structure in traditional cocoa forest gardens in southern Cameroon under different management
}

\author{
${ }^{1,2}$ Hervé D. B. Bisseleua and ${ }^{1}$ Stefan Vidal \\ ${ }^{1}$ Georg-August-University Goettingen, Department of Crop Sciences, Entomological \\ Section, Grisebachstr. 6, 37077 Goettingen, Germany; ${ }^{2}$ Institute of Agricultural Research \\ for Development (IRAD), Nkolbisson Regional Research Centre, BP 2067, Yaoundé, \\ Cameroon.
}

Corresponding author: Hervé D. B. Bisseleua; email: hbissel@gwdg.de

\begin{abstract}
Floristic surveys were performed in 17 traditional cocoa forest gardens under different management regimes in the humid forest area of southern Cameroon, to assess the impact of intensification on plant biodiversity. This impact was evaluated by analyzing species richness, vegetation structure, carbon sequestration and above ground biomass. We hypothesize that: (i) plant (tree and herbs) species richness is negatively correlated to management intensity and (ii) vegetational density predictably change with management intensity. Our results show that management as practiced in traditional cocoa forest gardens in southern Cameroon following a gradient of intensification from extensive cocoa forest gardens with high floristic diversity to intensive ones strongly impacts plant diversity, plant biomass and to some extend carbon storage with possible negative consequences on biodiversity. Great differences in species richness, species composition, and, for trees, diameter at breast height and basal area were evident among the five types of traditional cocoa forest garden systems investigated. In terms of plant species richness, we found a decreasing gradient of plant species numbers from extensive forest gardens to intensive ones. This study also highlights the importance of the Management Index (MI) for quantifying differences in the management; this index could be used to standardize certification procedures and assess conservation progress and
\end{abstract}


success. Our findings support the idea that traditional cocoa forest gardens can help to protect many forest species, sustains smallholder production and offer more scope for conservation of biodiversity, at both species-level and landscape-level. Moreover, diverse traditional cocoa forest gardens may help in regulating pests and diseases and allow for efficient adaptation to changing socioeconomic conditions.

Keywords: Agroecology; Biodiversity conservation; Cocoa agroforest; Intensification; Management index; management regime; Southern Cameroon

\section{Introduction}

Agroforestry involves either the incorporation of trees in agricultural cropping systems or the incorporation of crops in forest systems. Traditionally, agroforestry research has focused on the first development pathway (the incorporation of trees in agricultural cropping systems) with less attention on multi-strata cropping systems that mimic the structure of natural forests (Lefroy et al. 1999; Muschler and Beer 2001). In southern Cameroon the structure of the landscape is characterized by natural rainforest, forest gardens (mixed tree plantations surrounding or at some distance from villages, usually less intensively tended than homegardens and they include a higher percentage of native trees (Wiersum 2004), homegardens and annual field crops (Degrande and Duguma 2000). Several research projects have focused on homegardens with little attention to other types of agroforests such as traditional forest gardens (TFGs) (Guyer 1984; Ruf and Schroth 2004; Gockowski et al. in press). It is only since several years that these “intermediate" management systems (Michon and De Foresta 1997) are gradually receiving increasing interest (Laird et al. 2007; Sonwa et al. 2007). In such systems tree composition is adapted to local needs, and their structure is close to that of natural forests. Their management practices are influenced by their relationship to the other components of the land-use system and are oriented at using a combination of multiple forest resources (Sonwa et al. 2001; Schroth et al. 2004 and Perfecto et al. 2005). Their adaptive nature offers options for combining biodiversity conservation and production for human benefits (Greenberg et al. 2000; Reitsma et al. 2001; Perfecto et al. 2004; MCNeely and Schroth 2006; Gordon et al. 2007; Steffan-Dewenter et al. 2007). TFGs are developed as 
a result of the interactions between local communities and forests and reflect various forms of human creativity in dealing with forest resources. They could be regarded as a mixture of natural forest tree species such as fruit tree species, timber species, semicultivated woody plants (Elaeis guineensis) and cultivated plants (cocoa and bananas), presenting a high level of plant diversity, and potentially be of high conservation value (Zapfack et al. 2002; Bobo et al. 2006; Merijn et al. 2007; Sonwa et al. 2007). They form a dynamic component of an integrated local land-use system, providing supplementary products such as fruits, cash crops, firewood and/or medicines. Moreover, TFGs provide opportunities in developing new approaches in conservation of tropical rainforests and biodiversity, as well as increased recognition of indigenous land-use systems as a possible way for sustainable development (Gordon et al. 2007; Steffan-Dewenter et al. 2007).

This paper aims to demonstrate the impact of management intensity on plant diversity and vegetation structure of TFGs in southern Cameroon. This impact can be evaluated by analyzing species richness, vegetation structure, carbon sequestration and above ground biomass. We hypothesize that: (i) plant (tree and herbs) species richness and management intensity are negatively related (ii) vegetational density predictably change with management intensity.

\section{Material and method}

\section{Study sites}

Our surveys were conducted in the semi-deciduous rainforest region in five major cocoagrowing regions within 17 cocoa farms in southern Cameroon. The study areas are located between $2^{\circ} 35^{\prime} \mathrm{N}$ and $4^{\circ} 15^{\prime} \mathrm{N}$ and $11^{\circ} 48^{\prime}$ and $11^{\circ} 15^{\prime} \mathrm{E}$. The altitude varies between 450 and $715 \mathrm{~m}$ above sea level and is characterized by a sub-equatorial climate, with a bimodal rainfall regime. The mean annual temperature is around $25{ }^{\circ} \mathrm{C}$ with a relatively small thermal variation. The mean annual rainfall is around $1900 \mathrm{~mm}$. The soils are Oxisols/Ultisols, which make up about $80 \%$ of the soils in the humid forest region of Cameroon and the $\mathrm{pH}$ of the soil varies from 4.29 to 5.43 (Kotto-Same et al. 1997; Kanmegne et al. 2006). 
The five regions may be characterized as follows: (1) Ngomedzap is in the south around the Mbalmayo forest reserve, which is partially logged due to a low population density with old cocoa forest gardens ( $\sim 50$ years and more) near the forest margin or in the dense forest; (2) Obala in the centre, with no original forests remaining because of very high human population density and relatively old cocoa forest gardens ( $\sim 40$ years and more), located in strongly degraded semi-deciduous forest near houses and villages; (3) Bakoa and (4) Kedia in the northern extreme west with old ( $\sim 30$ years and more) and young ( 8 - 15 years) cocoa forest gardens respectively, in forest galleries at the forest-savannah transition zones; and (5) Talba in the northern extreme east with mature cocoa forest gardens ( $\sim 15-20$ years) in or near the forest. The Ngomedzap area is considered by cocoa farmers to be less technified (more dense and diverse shade, fewer chemical inputs) and could be compared to the "rustic" cocoa areas (Greenberg et al. 2000) reported in Latin America. The Kedia and Talba areas are considered to be more technified (less dense and diverse shade, high chemical inputs) and are seen as the pioneer front in cocoa cultivation in southern Cameroon.

Five Union of GICs (Common Initiative Group) and four federations of cocoa farmers within the five regions were identified and selected for the study, regrouping 41 GIC with a total of 2597 cocoa farmers (Chapter 2). In each region, the process started with a community meeting with the help of ASPA (Appui aux Stratégies Paysannes et à la Professionnalisation de l'Agriculture) of the Ministry of Agriculture and Rural Development (MINADER) to inform all cocoa farmers and the respective "Common Initiative Group" (GIC) about the objectives of the study and to ask for their participation and action planning. During the pilot phase, 20 cocoa farms were inspected per union. We selected the farms according to a land-use intensity gradient based on density, plant diversity, height of shade trees, percent of shade and herb cover and the age of cocoa trees (Phipott et al. 2006). The selected farms represented individual land holdings. Ngomedzap was considered as an extensively managed old traditional cocoa forest garden (EO), Bakoa as an extensively managed young traditional cocoa forest garden (EY), and Obala as a home garden cocoa forest (HG), because all plantations are located very close to the houses in the village. Talba was considered to be an intensively managed mature traditional cocoa forest gardens (IM) and Kedia as an intensively managed young traditional cocoa forest gardens (IY). The management practices in 
Bakoa were similar to that of Ngomedzap, but with less dense and diverse shade and moderate chemical inputs. Farmers in Bakoa claimed to have trained those of Talba in proper management of their cocoa plantations that resulted in their higher production. The rate of pesticides application, insecticides applied, the main used of plant species and intentionally introduced tree species were assessed through individual interviews with selected farmers. In all our study sites cocoa production was the main cash crop, occupied most of the landscape and accounted for more than half of the total cocoa production in southern Cameroon, with $28 \%$ of the total production of the whole country (Anon. 2002).

\section{Plant survey and estimation of tree biomass}

The ecological survey was performed between July and December 2005 in five cocoa growing regions in the humid forest area of southern Cameroon, which include both evergreen and deciduous rainforest. We selected 17 cocoa plantations (sites) within five types of traditional cocoa forest gardens (TFGs) namely EO, EY, HG, IM, and IY as follows: two EO (Ngomedzap), four EY (Bakoa), IM (Talba) and IY (Kedia) respectively, and three HG (Obala). Vegetation characteristics were determined within $600 \mathrm{~m}^{2}$ plots $(20 \times 30 \mathrm{~m})$ in each site. For each site, all non-cocoa trees with diameter at breast height $(\mathbf{d b h}) \geq 10 \mathrm{~cm}$ were individually counted, numbered, identified and their density per plot estimated. Their crown class, dbh, as well as their full height was measured and the basal area (BA) was calculated. The BA per quadrate $\left(600 \mathrm{~m}^{2}\right)$ was calculated as follows: BA $\left(\mathrm{m}^{2} / \mathrm{ha}\right)=\Sigma 0.00007854 \mathrm{D}^{2}$, where $\mathrm{D}$ is the dbh per tree. The BA is included to give a rough approximation of plant biomass production, which usually increases with age (Carrière et al. 2002). The above ground tree biomass was calculated using the equation $\ln B=-3.375+0.948 * \ln \left(D^{2} * H\right)($ Steffan-Dewenter et al. 2007), where $\mathrm{B}$ is the aboveground biomass, $\mathrm{D}$ is the $\mathrm{dbh}$ and $\mathrm{H}$ is the total tree height, respectively.

Herb species were sampled and counted in 15 quadrates of $2 \times 1 \mathrm{~m}$ in each plot per TFG. Scientific and vernacular names (the latter given by local cocoa farmers and local traditional practitioners) were recorded. The uses of each species (nutritive, timber, medicinal plants, fertilizers etc...) were also determined. Species that could not be identified in the field were collected, pressed in between newspaper for later 
identification at the National Herbarium of Cameroon (Yaoundé). Also, within each site, cocoa tree parameters (i.e. spacing between cocoa trees, tree density, cocoa tree height, girth, crown depth and width, height of branching, and the number of chupons per tree, respectively) were monitored to assess management practices. These 17 study sites had a minimum size of 1 ha and a minimum distance to the nearest neighbour of $500 \mathrm{~m}$. Sampling was standardized and performed on a spatial unit size comparable to typical management unit to avoid correction of richness data by rarefaction or through estimators. Diurnal temperature $\left({ }^{\circ} \mathrm{C}\right)$ and relative humidity $(\%)$ were measured under standardized conditions (sunny days, 8-10 am) in each plot. A combine Electronic handheld hygro-thermometer (TECPEL CO LTD, Taiwan: Model DTM 321_DTM 322) was used to measure temperature and relative humidity while daily rainfall was measured using a plastic pluviometer (Littoclime S.A, France). Canopy cover was measured at 10 points per site using a hand-held spherical densiometer (R.E. Lemmon Forest Densiometers, USA) to estimate shading intensity.

A management index (MI) (Mas and Dietsch 2003; Philpott et al. 2006) was used to summarize vegetation variables per site in each region whereby all variables subjected to be affected by management were converted to a scale from 0 to 1 and then summed. We divided values for each variable in each site by the highest overall value, and then subtracted this from 1. All values were summed for a total possible of 7 (since seven vegetative variables were included in the index), where 7 is most and 0 is leastintensively managed site.

\section{Diversity indices and statistical analysis}

The number of species $S$ (species richness) (Samways, 1984; Krebs, 1989), the Shannon index of diversity $H^{\prime}$ (Colwell and Huston, 1991), the Berger-Parker index of dominance $d$ (Magurran, 1988), and index of evenness $E$ (Shannon and Weaver, 1949) were selected to examine $\alpha$-diversity within all sites and habitat (TFG). We also used the Jaccard index (1) of plant similarity to examine $\beta$-diversity among the habitats.

$$
\mathrm{JI}=\mathrm{Sij} /(\mathrm{Si}+\mathrm{Sj}-\mathrm{Sij})
$$

Where $\mathrm{Sij}=$ shared species; $\mathrm{Si}=$ richness in first site; and $\mathrm{Sj}=$ richness in second site. Data were analyzed using either Systat 11 or SPSS version 11.0 (SPSS Inc. 2004). 
When necessary, logarithm, arcsine-square or square root-transformed variables were used to achieve normal distribution. We analyzed diversity data by comparing measures of $\alpha$-diversity per site to estimate heterogeneity. A two-factor (sites, habitats) unbalanced nested design was used for an ANOVA on each of the dependent variables $(S, H, d$ and $E$ ). The unbalanced design was necessary as a result of different numbers of sites for each habitat type. Diversity was compared within sites and sites nested within habitats. When the model found statistically significant differences in habitats and sites, Tukey's posthoc tests were used to determine which were significantly different. Data on species richness were analyzed by simple polynomial regression against canopy, aboveground biomass and herbaceous cover, respectively.

\section{Results}

\section{General description}

A total of 102 non-cocoa (companion) tree species and 260 herbaceous species were identified within the five traditional cocoa forest gardens. Species sampled belonged to 169 plant families; 56 families of trees and 113 families of the herbs. The richest families were Moraceae (11 species) and Mimosaceae (6) in trees and the Acanthaceae (23 species), Commelinaceae (12), Poaceae (10), Araceae (8), Rubiaceae (6) and Asteraceae (4) in the herbs. There was a significant difference $(\mathrm{p}<0.01)$ in the average number of tree $(\mathrm{F}=7.30, \mathrm{df}=4)$ and herbaceous $(\mathrm{F}=15.97, \mathrm{df}=4)$ families observed per TFG with $\mathrm{HG}$ recording the highest number of families from both plant groups and IM the lowest (Table 1). The most common tree species were Albizia adianthifolia and Ficus exasperata (17\% of the total species respectively) followed by Ficus mucuso and Discoglypremna caloneura (11\%) in EO; Ceiba pentandra in IY; Ficus exasperata and Newbouldia lewis in EY; Terminalia superba in IM and Pterocarpus soyauxii in HG. Most of them were intentionally introduced as shade trees specifically in EY and IY. Herbaceous species were dominated by Nephrolepis bisserata (Nephrolepideae) in EO; Chromolaema odorata, Oplismenus hirtellus, Laportia avalifolia and Commelina sp in IY; O. hirtellus, L. ovalifolia and Dicliptera verticillata in EY; Commelina sp, Acanthus montanus, Cythula prostata, Desmodium abscendens and L. ovalifolia in IM and 
Psychotria sp and O. hiertellus in HG. All the herb species sampled depend on the period of the year because weeding is practiced throughout the cropping season.

\section{Floristic diversity and habitat description}

The plant species richness, Shannon-Weaver index, Shannon evenness and the BergerParker index of dominance for each TFG are presented in Table 1. A significant difference $(p<0.01)$ was observed between TFGs when analyzing tree species and herbaceous species richness, respectively. The average tree species richness was two fold higher in EO (11.0) as compared to IY (5.3). IM recorded the lowest herbaceous species richness and herbaceous cover. The Shannon-Weaver index between TFGs ranged from 1.54 to 2.23 for tree species and from 2.45 to 3.10 for herbaceous species. A significant difference was observed between TFGs for both two variables. Nevertheless, EO was the most diverse TFGs when considering the plant diversity indices (Table 1).

When taking into consideration the Jaccard Index (JI), the floristic similarity between TFGs decreased with increasing intensification (Table 2). Therefore, $\beta$-diversity was lower between sites under different land-use management. However, the highest similarity in floristic composition occurred between EY and IY.

When looking at the management practices in different TFGs, we observed that spacing between cocoa trees varied from $1.3 \mathrm{~m}(\mathrm{SE}=0.1)$ in $\mathrm{HG}$ to $2.1 \mathrm{~m}(\mathrm{SE}=0.0)$ in IM (Table 3). Spacing significantly differed $(\mathrm{p}<0.01)$ between TFGs. The average cocoa tree height ranged from $6.4 \mathrm{~m}(\mathrm{SE}=0.0)$ in $\mathrm{EO}$ to $8.6 \mathrm{~m}(\mathrm{SE}=0.5)$ in $\mathrm{IM}$. Tree height did not show any significant difference between TFGs as did tree girth, crown width and height at branching. However, a significant difference $(p<0.01)$ was observed between TFGs on crown depth of cocoa trees and the mean number of chupons per cocoa tree. This value ranged from $0.1(\mathrm{SE}=0.0)$ in $\mathrm{EO}$ to $0.9(\mathrm{SE}=0.2)$ in $\mathrm{HG}$ while crown depth ranged from $2.6 \mathrm{~m}(\mathrm{SE}=0.3)$ in $\mathrm{EO}$ to $5.7 \mathrm{~m}(\mathrm{SE}=1.0)$ in $\mathrm{HG}$. There was a significant difference $(\mathrm{p}<0.01)$ in cocoa tree density between TFGs with HG having the highest density and IM the lowest with 1075 tree/ha (Table 3). The rate of pesticides application per cropping season significantly differed $(\mathrm{p}<0.001)$ between TFGs with the extensive cacao production systems having fewer pesticide applications as compared to the intensive ones (Figure 1). Insecticide application was found to be significantly different $(\mathrm{F}=17.21, \mathrm{df}=$ 4, $\mathrm{P}<0.001$ ) between TFGs with EO applying less insecticides (Figure 1). Of the 
insecticides applied $43 \%$ were Organochlorine, 20\% Carbamate, 17\% organophosphate, $14 \%$ nicotinoid and $4 \%$ pyrethroids.

\section{Vegetation structure}

Based on a one way-ANOVA, density of non-cocoa tree significantly differed $(\mathrm{p}<0.001)$ among TFGs with the density recorded in EO two-fold higher than that observed in IY (Figure 2). Diameter at breast height ( $\mathrm{dbh}$ ) and tree height of non-cocoa trees in TFGs are summarized in Figure 3. Both parameters significantly varied $(p<0.001)$ between TFGs. Mean dbh ranged from $62.25 \mathrm{~cm}(\mathrm{SE}=2.90)$ in $\mathrm{EO}$ to $135.85(\mathrm{SE}=13.46)$ in IM. Mean dbh was $93.49 \mathrm{~cm}(\mathrm{SE}=1.47)$ in $\mathrm{EY}, 124.42 \mathrm{~cm}(\mathrm{SE}=10.91)$ in $\mathrm{HG}$ and 115.97 $\mathrm{cm}(\mathrm{SE}=5.86)$ in IY. Average height value of non-cocoa was higher in older systems than in younger ones. This value was $43.90 \mathrm{~m}(\mathrm{SE}=3.35)$ in $\mathrm{EY}, 44.16 \mathrm{~m}(\mathrm{SE}=1.51)$ in $\mathrm{IY} ; 55.50 \mathrm{~m}(\mathrm{SE}=3.26)$ in $\mathrm{EO}, 64.04 \mathrm{~m}(\mathrm{SE}=3.61)$ in $\mathrm{HG}$ and $65.64 \mathrm{~m}(\mathrm{SE}=2.91)$ in IM. Finally, we found a weak, although non-significant relationship between $\mathrm{dbh}$ and tree height.

\section{Basal area (BA) and Biomass production}

Management had a significant $(\mathrm{p}<0.001)$ effect on BA with IY recording the lowest BA $\left(9.5 \mathrm{~m}^{2} / \mathrm{ha}\right)$. IM recorded the highest BA value $\left(46.7 \mathrm{~m}^{2} / \mathrm{ha}\right)$. Mean BA in HG was about two fold that of EY (Figure 4). Standing tree biomass significantly $(\mathrm{p}<0.001)$ decreased with intensification, with IY recording four fold lower trees biomass than IM and EO respectively. IM recorded the highest mean biomass per standing tree species with 374 $\mathrm{kg} /$ tree (Figure 4). We observed a positive relationship between standing non-cocoa tree biomass and canopy cover $\left(\mathrm{R}^{2}=0.37, \mathrm{p}<0.05\right)$. We also found a positive relationship between standing non-cocoa tree biomass and tree species richness, however this relationship was not statistically significant.

\section{Ethnobotany}

Farmers normally preserve either medicinal species, fertilizers, nutritive and/or timber species in their TFGs. Many non-timber forest products were observed in the TFGs

analyzed. These included the Sterculiaceae from plant genus Cola, used as "Kola" and aphrodisiacs. Ricinodendron heudelotii (Euphorbiaceae) and Mondia whitei 
(Periplocaceae) are used as spices. Fruits of several tree species, such as Voacanga africana, Ricinodendron heudelotii, Dacryodes edulis, Irvingia gabonensis, Mangifera indica and Psidium guayava are sold to the local market. A few plant species, such as Gnetum africanum (Okok) (specifically in HGs) are also preserved for local consumption as a staple vegetable. About $60 \%$ of the bark of tree species in EO, $45 \%$ in EY, and 1\% in IM, IY and HG, respectively, are peeled off for medicinal purposes.

\section{Management Index (MI)}

The one-way ANOVA of the mean Management Index (MI) values for each TFG revealed statistically significant differences among the five management systems $\left(F_{4,16}=\right.$ 7.94, $\mathrm{df}=4, \mathrm{p}<0.002$ ) (Table 4). A Tukey's multiple comparison test indicated EO to be significantly different as compared to the other four systems. IY contained the least shaded cacao production sites while EO contained the most shaded; HG and EY were intermediate. Based on the MI we found that plant diversity and biomass of standing tree species significantly decreased with intensification.

\section{Discussion}

\section{Floristic diversity and habitat description}

Our study documents that management as practiced in traditional cocoa forest gardens in southern Cameroon following a gradient of intensification from extensive cocoa forest gardens with high floristic diversity to intensive ones strongly impacts plant diversity, plant biomass and to some extends carbon storage with possible negative consequences on biodiversity (Kottto-Same et al. 1997; Greenberg et al. 2000; Reitsma et al. 2001). Great differences in species richness and composition were evident among the five traditional cocoa forest gardens. In terms of plant species richness, we found a decreasing gradient of plant species numbers from extensive forest gardens to intensive ones. However, the species richness in cocoa forest home gardens (HG) exceeds all other numbers in the study area. What could be currently observed is the proliferation of pioneers or early secondary trees and poor conditions for the establishment of late secondary and climax species, resulting, consequently, in a lowering of tree diversity. 
This could be explained by the current management practices, specifically where undergrowth is cleared out twice annually in extensive systems and more in intensive ones. Such clearing are not selective, and all regenerating trees are eliminated and only a few arboreal plants happen to escape the cuttings. On the other hand, this could also be explained by the fact that before the cocoa crisis (Duguma et al. 2001), cocoa farmers were encouraged by the Societé de devéloppement du Cacao (SODECAO) to plant leguminous tree species such as the Albizia spp in cocoa plantations to enhance soil fertility. Ficus spp., Ceiba pentandra, Terminalia superba and Milicia excelsa actively kept by the farmers, promote quick shading of the cocoa trees and are refuge for birds (Greenberg et al. 2000); beneficial insects (Philpott and Armbrecht 2006) and mammals (Rolim and Chiarello 2004). The young systems (EY and IY) present even higher densities of exotic tree species (Khaya senegalensis). On the other hand, the presence and conservation of secondary forests species in traditional cocoa forest gardens suggest that TFG could help to maintain biodiversity in landscapes where forest habitat is decreasing due to land-use pressure or may help to conserve endangered species (Zapfack et al. 2002; Schulze et al. 2004; Asare 2006; Bobo et al. 2006).

Herb species diversity was dominated by light-demanding herbs, specifically Acanthaceae, Commelinacea, Poaceae and Asteraceae in patches and may function as indicators of the type of management.

The relatively low Jaccard Indices suggest a high $\beta$-diversity due to a high species turnover. This is exemplified by the low proportion of shared species among the traditional cocoa forest gardens, specifically between EO and IY.

\section{Vegetation structure}

The average density of non-cocoa trees with $\mathrm{dbh} \geq 10 \mathrm{~cm}$ in traditional cocoa forest garden may be considered low (126 \pm 41.7 trees/ha) as compared to the less disturbed forest as reported by Zapfack et al. (2002). However, if compared to other cocoa systems such as the cabruca system in Brazil (Rolim and Chiarello 2004), this value is high. According to other studies (Steffan-Dewenter et al. 2007), planting of cocoa is economically viable at low tree density and thinning. Such practices may explain the type of land-use applied in intensive young systems (IY) resulting in poor plant diversity. However, farmers in these systems are concerned about the importance of tree as shade 
but lack appropriate technology in tree domestication or are not able to identify appropriate trees for shade.

The value of dbh in extensive TFGs were the lowest as compare to other TFGs and could be explained by a massive and selective logging during the cocoa crisis and the fall in market prices after 1992 (Duguma et al. 2001). Food diversification in HG (a combination of diverse fruit tree species in cocoa plantations), of similar age, has helped in preventing massive logging and plantations still possess timber tree species with significant dbh.

\section{Basal area (BA) and biomass production}

BA of timber species present in traditional cocoa forest gardens clearly decreased from young to old systems. The basal area of $46.7 \mathrm{~m}^{2} /$ ha from our mature systems, was higher than what was found by Zapfack et al. (2002) (i.e. $39.2 \mathrm{~m}^{2} /$ ha) and close to the value (i.e. $48.7 \mathrm{~m}^{2} / \mathrm{ha}$ ) recorded by Bobo et al. (2006) in primary forests in Southern Cameroon. It was also higher than the values $\left(11.9-20.5 \mathrm{~m}^{2} /\right.$ ha) obtained in cocoa plantations in Indonesia by Merijn et al. (2007) or elsewhere in the South province of Cameroon (29.7$42.6 \mathrm{~m}^{2} / \mathrm{ha}$ ) where some large trees $(\mathrm{e} . \mathrm{g} . \mathrm{dbh}=143 \mathrm{~cm})$ can still be found despite ancient selective logging activities (van Gemerden 2004). Our results suggest a good stock of remnant forest tree species such as Terminalia superba, Milicia excelsa, Mansonia altissima, Entandrophragma cylindricum and planted multi-purpose trees such as oil palms Elaeis guineensis, plum Dacryodes edulis and kola Cola acuminate in TFGs.

The large differences in above ground tree biomass among old and young TFGs are a good indication of the rate of intensification where farmers aimed at maximum cocoa productivity. Such practice may results in a significant loss of carbon (Kotto-Same et al. 1997; Steffan-Dewenter et al. 2007). According to Steffan-Dewenter et al. (2007) the removal of shade trees increased soil surface temperature by about $4^{\circ} \mathrm{C}$ and reduced relative air humidity at $2 \mathrm{~m}$ above ground by about $12 \%$. These factors may have significant impact on the incidence of pests and diseases. We can also predict that the rate of biomass accumulation will probably decline as stands age because the dominant tree species are of economic importance and could be sold if there is a drastic drop of cocoa

price at the international market. But TFGs will be profitable and sustainable if diversification of both crop and non-crop commodities such as non-timber forest products 
and fruit tree species is advocated (Zapfack et al. 2002; Bobo et al. 2006; Sonwa et al. 2007).

\section{Management Index (MI) and vegetation variables}

The results of vegetative sampling and analysis of the Management Index (Table 4) clearly demonstrate that significant and measurable differences of MI can be quantified between different management systems of traditional cocoa forest gardens. Richness of non-cocoa tree species, herbaceous species, the average tree height, percentage of canopy and herbaceous cover were the principal variables explaining these differences. These results suggest the importance of TFGs as refuge areas for biodiversity, and subsequent structural diversity.

Three significantly different management systems could be identified among the traditional cocoa forest gardens studied: (1) The extensively managed cocoa forest gardens (EO), with the lowest MI and higher shade cover, as well as tree species richness; (2) the intermediate forest gardens (EY and $\mathrm{HG}$ ) with intermediate $\mathrm{MI}$; and (3) the intensively managed systems (IM and IY) with the highest MI and lowest shade cover and tree species diversity (Table 1 and 4). Such approach using a management index (MI) could be used for research and certification in the cocoa growing regions of the tropics, specifically in West and Central Africa where such indices do not exit. Traditional cocoa forest gardens in southern Cameroon are protected land-use systems where medicinal and edible plants, timber species and non-timber forest products are collected.

\section{Conclusion}

The results of this study documents that management as practiced in traditional cocoa forest gardens in southern Cameroon following a gradient of intensification from extensive cocoa forest gardens with high floristic diversity to intensive ones strongly impacts plant diversity, plant biomass and to some extends carbon storage with possible negative consequences on biodiversity. However, domestication of forest species within the TFGs is one of the best options for satisfying certain social and economic needs and sustains smallholder production for increased social, economic and environmental benefits. Such multiresource land-use practices that create new landscape elements offer 
more scope for conservation of biodiversity, at both species-level and landscape-level, may help in regulating pests and diseases and allows for efficient adaptation to changing socioeconomic conditions. This study also highlights the importance of the Management Index (MI) for quantifying differences in the management of shade-grown cocoa. MI in relation to biodiversity, productivity and net income was assessed (Bisseleua and Vidal, In press) and we argue that MI could be used to standardize vegetation sampling protocols in certification and biodiversity evaluations and monitoring or to measure conservation progress and success. Such a certification scheme is well established for shade-grown coffee in Mesoamerica (Dietsch et al. 2004; Perfecto et al. 2005 and Gordon et al. 2007) but does not exist for cocoa in West and Central Africa. Therefore, it would be very useful to combine the application of this MI with data on the faunal richness (birds, mammals, beneficial insects) to assess the impact on pests and diseases as well as for the conservation of biodiversity based on the type of management.

\section{Acknowledgements}

We thank the University of Goettingen (IPAG "International PhD Programme in Agricultural Sciences in Goettingen") for financial support. We are grateful to the staff of the laboratory of Entomology of IRAD, Nkolbisson (Yaoundé) for support during field work and farmers and their respective federations in Ngomedzap, Bakoa, Nkolombang, Talba and Kedia for their active collaboration during field work. We also tank our colleagues of the Cameroon National Herbarium (Yaoundé) for their help on plant identification and conservation. 


\section{References}

Annon. (2002) Rapport Annuel du Ministère de l'Agriculture et du Développement Rural. pp 70.

Asare R. (2006) A review on cocoa agroforestry as a means for biodiversity conservation. Forest and Landscape Denmark, p 17.

Bobo S.K., Waltert M., Sainge M.N., Njokagbor J., Fermon H., Mühlenberg M. (2006) From forest to farmland: species richness patterns of trees and understorey plants along a gradient of forest conversion in Southwestern Cameroon. Biodiv. and Conserv. 15:40974117

Carrière M.S., Letourmy P. and Mckey D.B. (2002) Effects of remnant trees in fallows on diversity and structure of forest regrowth in a slash-and-nurn agricultural system in southern Cameroon. J. Trop. Ecol. 18: 375 - 396.

Colwell, R.K. and Huston, M.A. (1991) Conceptual framework and research issues for species diversity at the community level. In: Solbrig OT (ed) From genes to ecosystems: a research agenda for diversity. International Union of Biological Sciences, Paris, France.

Degrande A. and Duguma B. (2000) Adoption potential of rotational hedgerow intercropping in the humid lowlands of Cameroon. AgREN 103: 1 - 12.

Dietsch, T., Philpott, S.M., Rice, R., Greenberg, R., Bichier, P. (2004) Conservation policy in coffee landscapes. Science 303: 625.

Duguma B. (1993) Description of land use systems in the humid lowlands of Cameroon. In: Kiki A and Tiki-Manga T. (ed) Biophysical and socio-economical characterization of the humid forest zone of Cameroon. Proceedings of the National Symposium of the Cameroon ASB Project, 6 - 8 December 1993, Kribi, Cameroon. 
Duguma, B., Gockowski, J. and Bakala, J. (2001) Smallholder cacao (Theobroma cacao Linn.) cultivation in agroforestry systems of West and Central Africa: Challenges and opportunities. Agroforest. Syst. 51: $177-188$.

Gordon C., Manson R., Sundberg J. and Cruz Angón A. (2007) Biodiversity, profitability, and vegetation structure in a Mexican coffe agroecosystem. Agr. Ecosyst. Environ. 118: 256 - 266.

Greenberg R. Bichier P. and Cruz Angón A. (2000) The conservation value for birds of cacao plantations with diverse planted shade in Tabasca, Mexico. Anim. Conserv. 3: 105 -112 .

Guyer J.I. (1984) Family and farm in Southern Cameroon. African Research Studies No 15. Boston University African Studies Center, Boston.

Kanmegne J., Smaling E.M.A., Brussaard L., Gansop-Kouomegne A. and Boukong A. (2006) Nutrient flows in smallholder production systems in the humid forest zone of southern Cameroon. Nutr. Cycl. Agroecosys. 76: 233-248.

Kotto-Same J., Woomer P.L., Moukam A. and Zapfack L. (1997) Carbon dynamics in slash-and-burn agriculture and land use alternatives of the humid forest zone in Cameroon. Agr. Ecosys. Environ. 65: 245 - 256.

Krebs, C.J. (1989) Ecological methodology. Harper and Row, New York, New York, USA.

Lefroy E.C., Hobbs R.J., O’Connor M.H. and Pate J.S. (1999). Agriculture as a mimic of natural ecosystems. Agroforest. Syst. 31: $275-436$.

Letouzey (1985) Notice de la carte phytogéographique du Cameroun au 1:500 000. Institut de la carte international de la végétation, Toulouse, France. 
Magurran, A.E. (1988) Ecological diversity and its measurement. Princeton University Press, Princeton, New Jersey, USA.

Mas H.A. and Dietsch V.T. (2003) An index of management intensity for coffee agroecosystems to evaluate butterfly species richness. Ecol. Appl. 13: 1491 - 1501.

MCNeely J.A. and Schroth G. (2006) Agroforestry and biodiversity conservationtraditional practices, present dynamics, and lessons for the future. Biodiv. Conserv. 15: $549-554$.

Merijn M. B., Steffan-Dewenter, I. and Tscharntke T. (2007) The contribution of cacao agroforests to the conservation of lower canopy ant and beetle diversity in Indonesia. Biodiv. Conserv. 16: $2429-2444$.

Michon G. and De Foresta H. (1997) Agroforest: pre-domestication of forest trees or true domestication of forest ecosystems? Neth. J. Agr. Sci. 45: $451-462$.

Muschler R. and Beer J. (2001) Multistrata agroforest systems with perenial crops. Agroforest. Syst. 53: $85-245$.

Laird, S. A., Leke Awung, G. and Lysinge, R. J. (2007) Cocoa farms in the Mount Cameroon region: biological and cultural diversity in local livelihoods. Biodiv. Conserv. 16: $2401-2427$.

Perfecto I., Vandermeer J.H., Bautista G.L., Ibarra Nuñez G., Greenberg R., Bichier P., and Langridge S. (2004) Greater predation in shaded coffee farms: The role of resident neotropical birds. Ecology 85: 2677 - 2681.

Perfecto I., Vandermeer J., Mas A., and Soto Pinto L. (2005) Biodiversity, yield, and shade coffee certification. Ecol. Econ. 54: 435- 446 
Philpott S. and Armbrecht I. (2006) Biodiversity in tropical agroforests and the ecological role of ants and ant diversity in predatory function. Ecol. Entomol. 31: $369-377$.

Philpott S. M., Perfecto I. amd Vandermeer J. (2006) Effects of management intensity and season on arboreal ant diversity and abundance in coffee agroecosystems. Biodivers. Conserv. 15: $139-155$.

Reitsma R., Parrish J.D. and McLarney W. (2001) The role of cocoa plantations in maintaining forest avian diversity in southeastern Costa Rica. Agroforest. Syst. 53: 185 193.

Rolim G.S. and Chiarello G.A. (2004) Slow-death of Atlantic forest trees in cocoa agroforest in southern Brazil. Biodivers. Conserv. 13: 2679 - 2694.

Ruf F. and Schroth G. (2004) Chocolate forests and monocultures: a historical review of cocoa growing and its conflicting role in tropical deforestation and forest conservation. In: Schroth G, da Fonseca GAB, Harvey CA, Gascon C, Vasconcelos HL, Izac AMN (eds) Agroforestry and biodiversity conservation in tropical landscapes. Island Press, Washington, pp 107-134.

Samways M.J. (1984) Community structure of ants (Hymenoptera: Formicidae) in a series of habitats associated with citrus. J. Appl. Ecol. 20: 833-847.

Schroth G., da Fonseca G.A.B., Harvey C.A., Gascon C., Vasconcelos H.L., Izac A-M.N. (2004) Agroforestry and Biodiversity Conservation in Tropical Landscapes. Island, Washington, DC.

Schulze C.H., Waltert M., Kessler P.J.A., Pitopang R., Shahabuddin, Veddeler D., Mühlenberg M., Gradstein R.S., Leuschner C., Steffan-Dewenter I. and Tscharntke T. (2004) Biodiversity indicator groups of tropical land-use systems: comparing plants, birds, and insects. Ecol. Appl. 14: 1321 - 1333 
Shannon, C.E. and Weaver, W. (1949) The mathematical theory of communication. University of Illinois Press, Urbana, Illinois, USA.

Sonwa, D.J., Weise, S. F., Tchatat, M., Nkongmeneck, B.A., Adesina, A.A., Ndoye, O. and Gockwoski, J. (2001) The role of cocoa agroforests in rural and community forestry in southern Cameroon. RDFN Paper. 25: 1 - 10.

Sonwa, D. J., Nkongmeneck, B. A., Weise, S. F., Tchatat, M., Adesina, A.A. and Jansens, M. J. J. (2007) Diversity of plants in cocoa agroforests in the humid forest zone of Southern Cameroon. Biodivers. Conserv. 16: 2485 - 2400.

SPSS Inc. (2004) Systat 11 for Windows. SPSS Inc., Chicago.

Steffan-Dewenter I., Kessler M., Barkmann J, Bos M., Buchori D., Erasmi S., Faust H., Gerold G., Glenk K., Gradstein R.S., Guhardja E., Harteveld M., Hertel D., Höhn P., Kappas M., Köhler S., Leuschner C., Maertens M., Marggraf R., Migge-Kleian S., Mogea J., Pitopang R., Schaefer M., Schwarze S., Sporn G.S., Steingrebe A., Tjitrosoedirdjo S.S., Tjitrosoemito S., Twele A., Weber R., Woltmann L., Zeller M., Tscharntke T. (2007) Tradeoffs between income, biodiversity, and ecosystem functioning during tropical rainforest conversion and agroforestry intensification. PNAS 104: 4973 4978

van Gemerden B.S. (2004) Disturbance, Diversity and Distributions in Central African Rain Forest. PhD thesis, Wageningen University, The Netherlands.

Wiersum K.F. (2004) Forest gardens as an 'intermediate' land-use system in the natureculture continuum: Characteristics and future potential. Agroforest. Syst. 61: 123-134.

Zapfack L., Engwald S., Sonke B., Achoundong G., and Birang M. (2002) The impact of land conversion on plant biodiversity in the forest zone of Cameroon. Biodivers. Conserv. 11: $2047-2061$. 


\section{List of Figures}

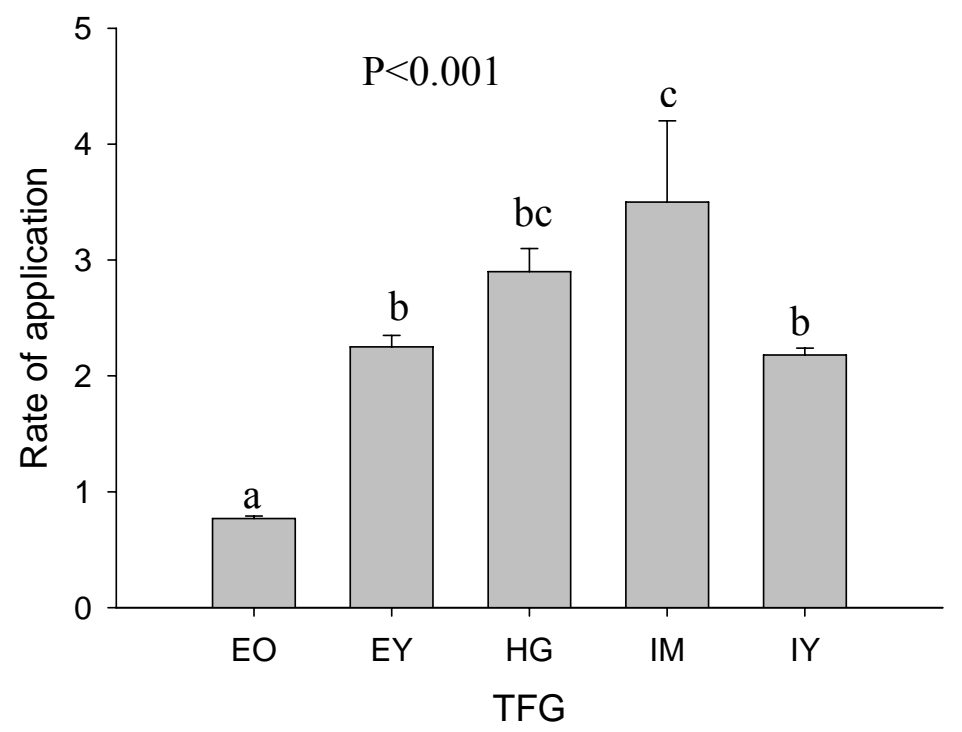

Figure 1. Rate of Insecticides application in different traditional cocoa forest gardens $(\mathrm{F}=17.21, \mathrm{~d} . \mathrm{f}=4, \mathrm{n}=17)$

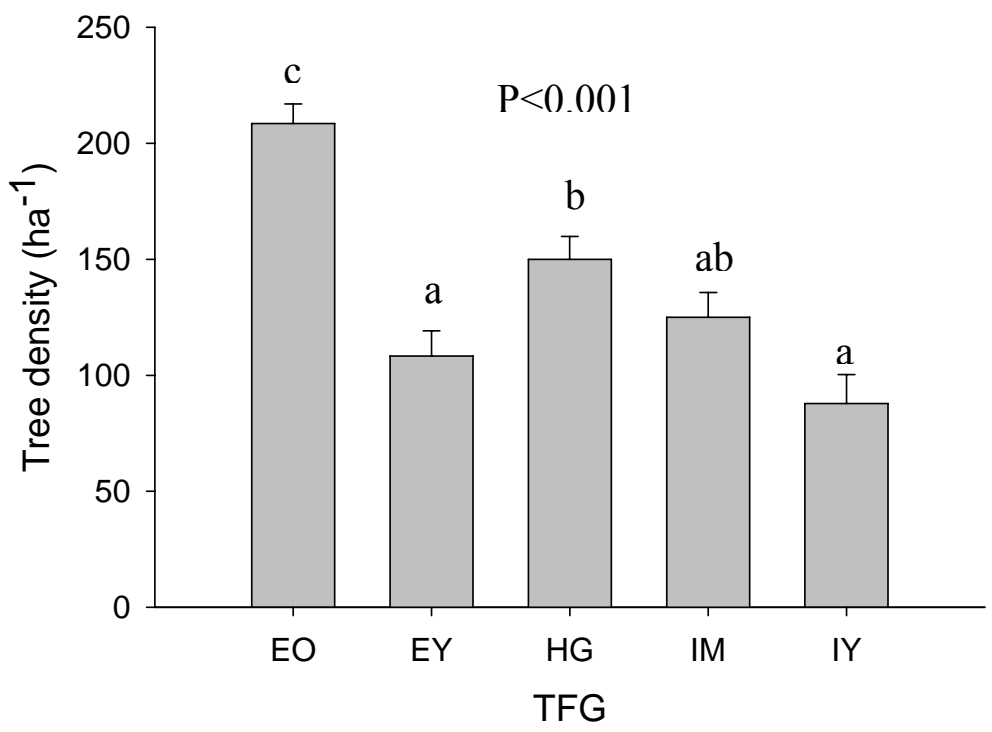

Figure 2. Average tree density $\left(\mathrm{ha}^{-1}\right)$ in different traditional cocoa forest gardens 

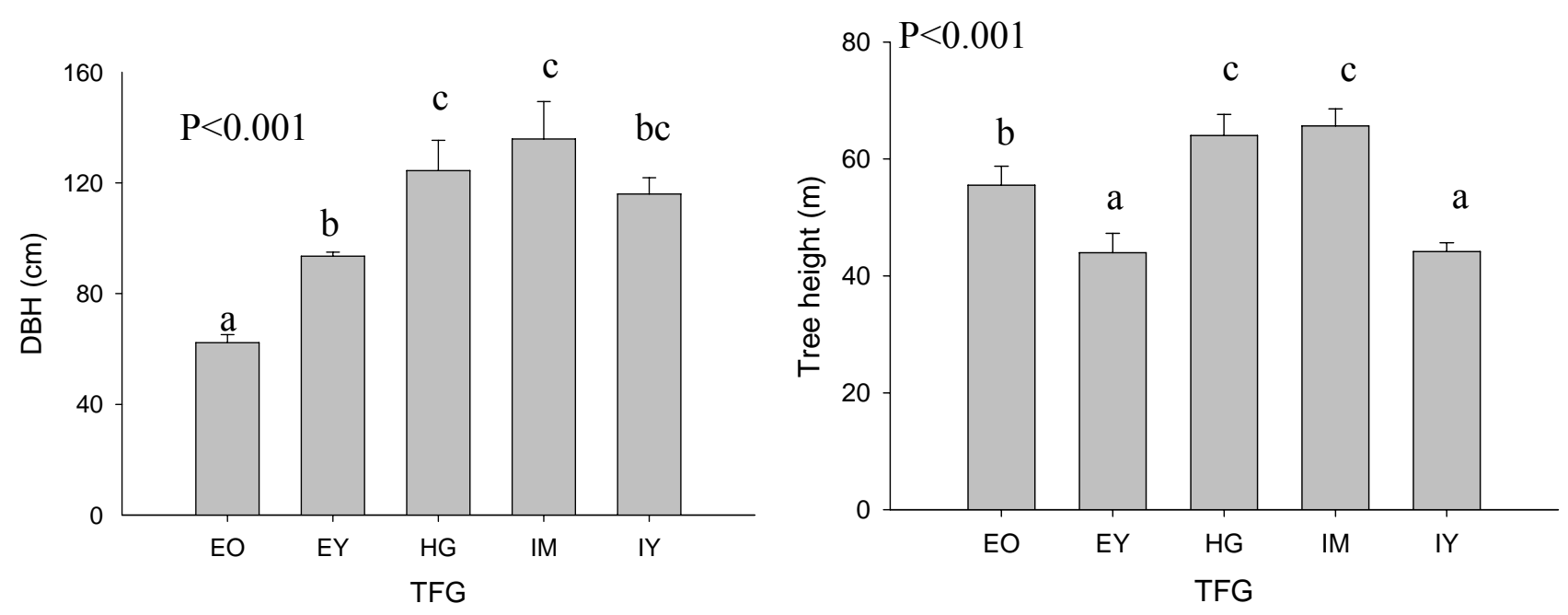

Figure 3. Diameter at breast height $(\mathrm{cm})$ and tree height $(\mathrm{m})$ of non-cocoa trees in five land-use systems of traditional cocoa forest gardens in southern Cameron
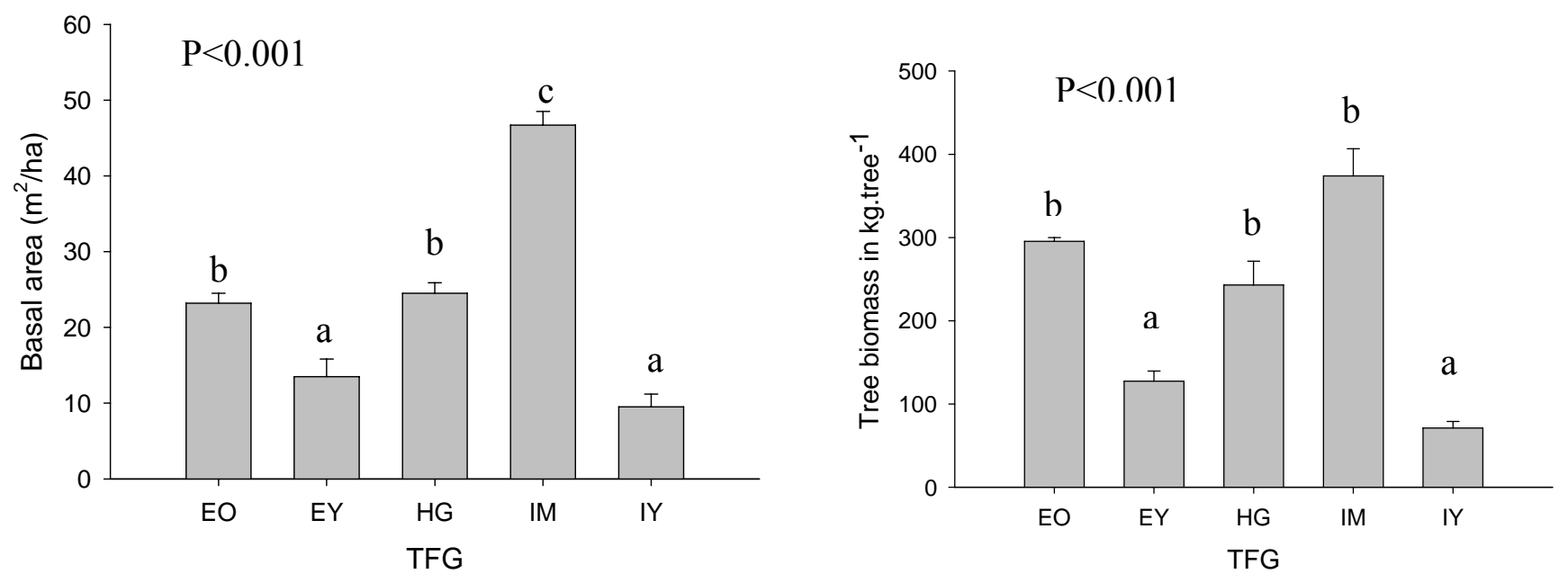

Figure 4. Basal area $\left(\mathrm{m}^{2} / \mathrm{ha}\right)$ and tree biomass $(\mathrm{kg} / \mathrm{tree})$ of non-cocoa tree species in five TFG 


\section{List of Tables}

Table 1. Floristic (Non-cocoa tree and herbaceous) species diversity indices in the different traditional cocoa forest gardens (TFG)

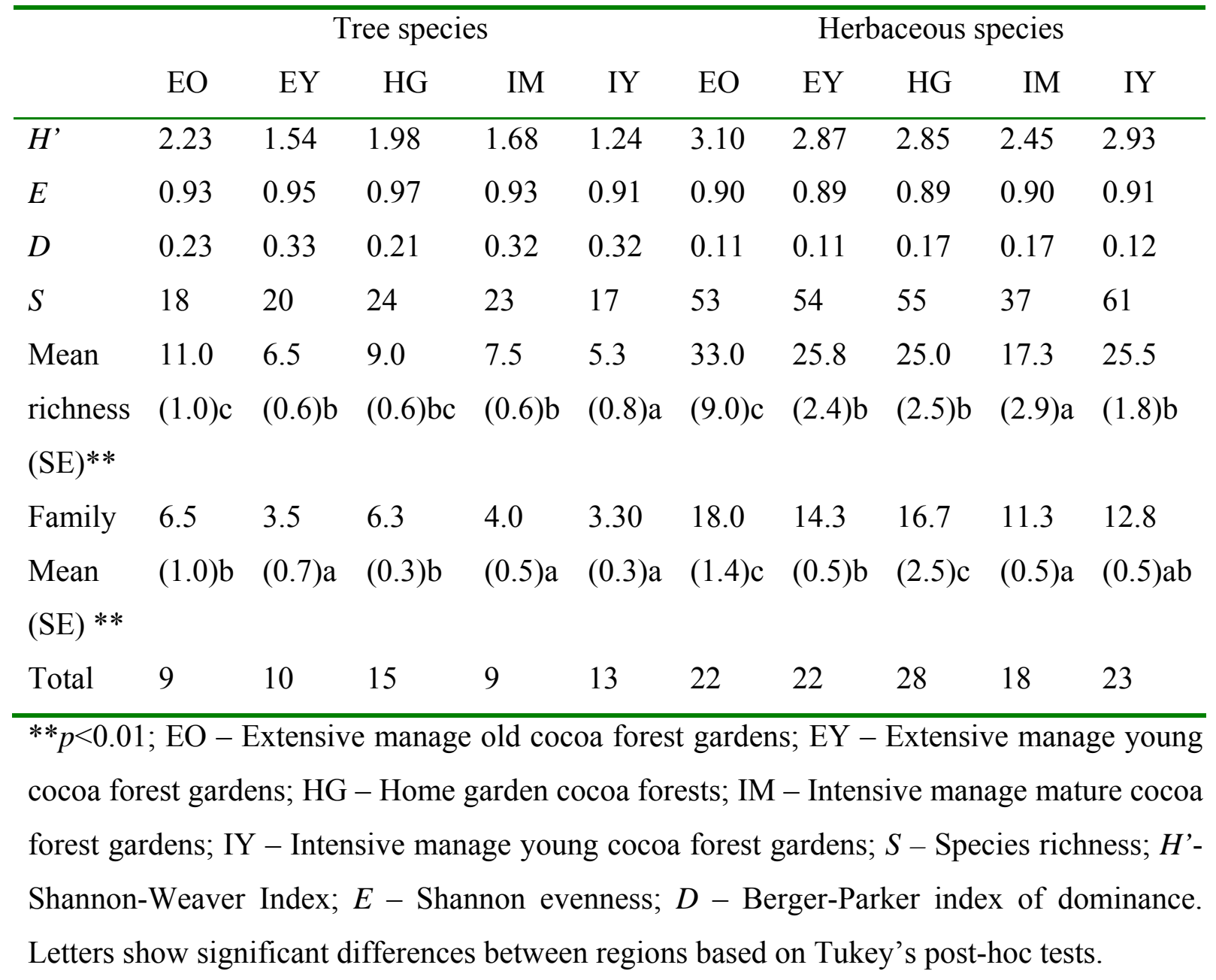


Table 2. Percent similarity in non-cocoa (companion) trees species for all traditional cocoa forest gardens (TFG).

\begin{tabular}{cccccc}
\hline \multicolumn{5}{c}{ Non-cocoa tree species } \\
TFG & EO & EY & HG & IM & IY \\
\hline EO & & 17 & 12 & 11 & 12 \\
EY & & 12 & 15 & 33 \\
HG & & & 14 & 15 \\
IM & & & & 19 \\
\hline \multicolumn{7}{r}{ Herbaceous species } \\
EO & EO & EY & HG & IM & IY \\
EY & & 34 & 27 & 10 & 16 \\
HG & & 28 & 25 & 28 \\
IM & & & 17 & 16 \\
\hline
\end{tabular}

Table 3. Management practices applied and cocoa trees parameters in different TFG

\begin{tabular}{|c|c|c|c|c|c|c|c|c|}
\hline Locality & $\mathrm{DCC}(\mathrm{m})$ & ATH (m) & TG (m) & CW (m) & $\mathrm{CD}(\mathrm{m})$ & AHB (m) & NBT & $\begin{array}{c}\text { ATD } \\
\text { (Tree/ha) }\end{array}$ \\
\hline EO & $1.7(0.2) b$ & $6.4(0.0)$ & $0.3(0.0)$ & $2.2(0.0)$ & $2.6(0.3) \mathrm{a}$ & $1.5(0.1)$ & $0.2(0.0) \mathrm{a}$ & $1250(50) \mathrm{ab}$ \\
\hline EY & $1.8(0.2) \mathrm{c}$ & $9.4(0.7)$ & $0.5(0.0)$ & $2.5(0.2)$ & $5.6(0.5) \mathrm{c}$ & $0.5(0.2)$ & $0.5(0.1) \mathrm{ab}$ & $1183(80.5) \mathrm{a}$ \\
\hline HG & $1.3(0.1) \mathrm{a}$ & $9.9(0.8)$ & $0.5(0.1)$ & $2.5(0.2)$ & $5.7(1.0) \mathrm{c}$ & $1.1(0.6)$ & $0.9(0.2) \mathrm{b}$ & $1600(208.2) b$ \\
\hline IM & $2.1(0.0) \mathrm{c}$ & $8.6(0.5)$ & $0.4(0.0)$ & $2.4(0.3)$ & $5.5(0.4) \mathrm{c}$ & $1.6(0.2)$ & $0.3(0.1) \mathrm{a}$ & $1075(96.8) \mathrm{a}$ \\
\hline IY & $2.0(0.1) \mathrm{c}$ & $7.6(0.8)$ & $0.4(0.0)$ & $2.6(0.2)$ & $3.7(0.3) \mathrm{a}$ & $1.3(0.1)$ & $0.1(0.1) \mathrm{a}$ & 1095 (69.10)a \\
\hline$p$ & $* *$ & NS & NS & NS & $* *$ & NS & $* *$ & $* *$ \\
\hline & \multicolumn{8}{|c|}{$\begin{array}{l}{ }^{* *} p<0.01 \text {; EO - Extensive manage old cocoa forest gardens; EY - Extensive manage young } \\
\text { cocoa forest gardens; HG - Home garden cocoa forests; IM - Intensive manage mature cocoa } \\
\text { forest gardens; IY - Intensive manage young cocoa forest gardens; DCC - Distance between } \\
\text { two consecutives cocoa tree; ATH - Average tree height; TG - Tree girth; CW - Crown } \\
\text { width; CD - Crown depth; AHB - Average height at branching; NBT - Number of chupons } \\
\text { per cocoa tree; ATD - Average tree density per farm. Values are mean (SE) and NS - Not } \\
\text { significant. Letters show significant differences between regions based on Tukey's post-hoc }\end{array}$} \\
\hline
\end{tabular}


Table 4. Management index (MI) from vegetation characteristics sampled in five cocoa forest gardens regions

\begin{tabular}{|c|c|c|c|c|c|}
\hline Vegetation variables & $\mathrm{EO}$ & EY & $\mathrm{HG}$ & IM & IY \\
\hline Tree species richness (no) & 0.48 & 0.69 & 0.57 & 0.64 & 0.75 \\
\hline Herbaceous species richness (no) & 0.46 & 0.58 & 0.59 & 0.74 & 0.58 \\
\hline Canopy cover $(\%)$ & 0.12 & 0.27 & 0.16 & 0.24 & 0.56 \\
\hline Herbaceous cover $(\%)$ & 0.15 & 0.22 & 0.78 & 0.92 & 0.67 \\
\hline Tree height (m) & 0.46 & 0.57 & 0.38 & 0.36 & 0.57 \\
\hline Number of chupons & 0.95 & 0.89 & 0.77 & 0.93 & 0.97 \\
\hline Cocoa tree density (tree/ha) & 0.38 & 0.41 & 0.20 & 0.46 & 0.45 \\
\hline Total Management Index (MI) (A) & $2.98 \mathrm{a}$ & $3.63 b$ & $3.45 b$ & $4.29 c$ & $4.55 \mathrm{c}$ \\
\hline (B) & 1.67 & 2.33 & 2.48 & 2.90 & 3.13 \\
\hline
\end{tabular}
${ }^{* *} p<0.01$; A high MI shows more intensive cocoa management. Letters show significant differences between regions based on Tukey's post-hoc tests. A - MI using seven variables; B - MI using five variables. 


\title{
Perception of cocoa agroforest management by farmers after introducing IPM in Farmer's organizations in southern Cameroon
}

\author{
${ }^{1,2}$ Hervé D. B. Bisseleua and ${ }^{1}$ Stefan Vidal \\ ${ }^{1}$ Georg-August-University Goettingen, Department of Crop Sciences, Entomological \\ Section, Grisebachstr. 6, 37077 Goettingen, Germany; ${ }^{2}$ Institute of Agricultural Research \\ for Development (IRAD), Nkolbisson Regional Research Centre, BP 2067, Yaoundé, \\ Cameroon.
}

Corresponding author: Hervé D. B. Bisseleua; email: hbissel@gwdg.de

\begin{abstract}
Cocoa a tropical evergreen tree holds great economic importance for small crop farmers in the humid forest of southern Cameroon. Cocoa like many tropical plantation crops has become increasingly a crop of the small-scale farmer, as a result of changes in demography and national policy. Although production has increased consistently since the cocoa crisis, it is still less than the level achieved in other producing countries because of pests, diseases, and non-adoption of research recommendations. Based on idea that recommendations to cocoa farmers were not adapted to their localities, we use a survey of 400 cocoa farmers to assess farmers' indigenous knowledge of cocoa agroforest management, problems encountered, the pest controlled, alternative sources of income, institutional constraints in using certain indigenous pest control methods and the impact of farmer field schools on cocoa agroforest management. The cocoa farmers described a complex situation in which a range of abiotic and biotic factors constrained their cocoa-based livelihoods. They mentioned biological, institutional and socio-economic production constraints. Biological problems relate to pest damages and diseases most of which have received extensive research attention in Cameroon and low soil fertility which have been neglected. The institutional and socio-economic problems relate to low price of cocoa, expensive inputs,
\end{abstract}


lack of technical assistance, labour shortages and high cost of labour due to youth migration to the cities as a consequence of the lack of facilities like electricity. It was observed that these two categories of causes are closely inter-related with an impact on productivity. Local knowledge is often region specific and recommendations must be adapted to each producing area. Our study has identified potential areas that researchers and policy makers need to focus their attention to, to facilitate the development of coherent innovations. Introducing high-yielding varieties or encouraging specific pest and disease control strategies is likely to yield limited success if some important social and technical issues are not respected. Solutions for high productivity of cocoa in southern Cameroon will rely on a coherent package of social and technical solutions.

Keywords: Farmer indigenous knowledge, IPM, smallholder, cocoa farmers, participatory action research

\section{Introduction}

Cocoa (Theobroma cacao L.) is grown in the shade of other trees, but cocoa is increasingly grown with thinner shade or in full sun specifically in the centre-east and centre-west of the humid Rainforest of southern Cameroon. Cocoa accounts for only around $6 \%$ of Cameroon's exports, and is of crucial importance for its economy. Around $60 \%$ of the active population depends for most of their revenue on their earnings from cocoa and coffee. An estimated 450,000 rural households (more than a third of the total number of rural households) earned the larger part of their cash income from cocoa. A survey conducted in 2002 showed that the total acreage under cocoa cultivation in Cameroon was roughly about 420,000 hectares. Current production level averages $130,000 \mathrm{Mt}$ per annum, with aims of raising this to 200,000 Mt by the year 2010 . However, despite the economic importance of cocoa and farmers' sustained interest in production, yields of cocoa continue to be lower in Cameroon than in other major producing countries. Whilst the average cocoa yield in Malaysia is $1800 \mathrm{~kg} / \mathrm{ha}, 800 \mathrm{~kg} / \mathrm{ha}$ in Ivory Coast and $360 \mathrm{~kg} / \mathrm{ha}$ in Ghana (Dormon et al., 2004), it is only about $300 \mathrm{~kg} / \mathrm{ha}$ in Cameroon. Reasons for the low productivity are poor farm maintenance practices, planting of low-yielding varieties, ravages caused by pests' such as mirids (Salhbergella 
singularis H.)( Mpé, 2002), diseases (Phytophthora species: P. megakarya) (Gregory et al., 1985; Nyasse, 1992), poor soil fertility caused by prolonged cultivation on farmlands. Other causes include removal of agricultural subsidies, increased cost of chemicals and spraying equipments and the low prices paid to Cameroonian cocoa farmers (Sonwa et al., 2002).

Cocoa sector was fully liberalized in 1994/95 following the cocoa crisis with the abolition of minimum producer prices and the mechanism of price stabilization. These factors led to the inactivity of most cooperatives in cocoa trade and the country's exports became dominated by international traders. To date, farmers generally sell directly to private traders on the best offer basis. There is an active competition among buyers in nearly all of the cocoa producing areas. The abolition of National Commodities Marketing Board (ONCPB) has generated a new type of smallholder farmer's association, known as the "Common Initiative Groups" (Groupements d'Initiative Commune, GIC). A law in 1992 allowed the creation of these relatively "light", specialpurpose oriented cooperative entities who are not allowed to hold fixed assets (e.g., warehouses) or capital goods (e.g., trucks), and are not eligible to borrow from banks and must publish their financial accounts once each two years. They have quickly become important in a few cocoa producing areas, particularly in the Centre. They are active at the level of a village, grouping in general between 40 and 100 producers. They have developed into more advanced structures in recent years such as "Union of GICs" (made up of four to ten GICs) and federation (five to eight Unions). These structures act as the farmers' marketing body, grouping cocoa produced by their members, for selling, through a tender or auctioning system in larger volumes, therefore achieving a better profit. Several of them are very well organized providing information on prices on the international market, buying inputs, providing technical assistance and training of members.

Agricultural research schemes are generally drawn up and implemented without systematic participation of and consultation with farmers. Generally, agriculture in tropical regions is complex and risk-prone using few external inputs and has multiple purposes (Reijntjes et al., 1992), hence requiring site-specific solutions and active involvement of farmers. However, farmers' perception is not often given the requisite research attention. Conventional agricultural research based on 'linear ways of thinking' 
has largely failed to provide the desired technologies and innovations that meet the needs of resource-poor farmers (Van Huis and Meerman, 1997). Technologies developed for these farmers frequently have not been adopted, or have failed with negative social consequences, mostly because the research was conducted without adequate participation of farmers and with little consideration of farmers' own knowledge, practices, needs, and desires (Röling, 1996). Conventional practice using top-down approaches assume that researchers are the custodians of knowledge and the source of technical innovations, that extension is a delivery mechanism and farmers are the 'ultimate users' (Bruin and Meerman, 2001), putting farmers into a reactive rather than a proactive role.

Understanding indigenous knowlegde of smallholders in managing their cocoa plantations is very important in designing a sound and compatible integrated cocoa plantations management programme (ICPM). The requirement for ICPM in smallholder cocoa plantations is very different from that in the developed world. The total amount of synthetic pesticides used by smallholders is very small and they are characteristically risk-averse and their primary strategy is towards food security for their family. The more food insecure, the more risk-averse the farmer becomes and therefore even less likely to invest in off-farm inputs. Therefore ICPM should be driven by the need to increase yields and/or quality with minimal expenditure on external inputs.

ICPM should be considered as a decision support system for the selection and use of pest and disease control tactics, harmoniously co-ordinated into a management strategy that takes into account the interests of and impact upon smallholders, its society and the environment. Enhancing farmers' environmental knowledge may be the most direct way to enhancing farmers, crop and resource base management. So one of the major challenges of cocoa agroforestry research and extension is how it can be made into truly participatory activity in which farmers are not passive recipients of technology but key players in identifying, analyzing, designing and implementing research activities based on the ideas and experiences derived from indigenous knowledge and formal science.

This present study focuses on analyzing management practices in traditional cocoa forest garden such as that practiced in southern Cameroon. Scientists know little about farmers' knowledge, perceptions, practices and constraints and how they cope with various changes and interactions within the cocoa agroforest system after liberalization. The 
particular interest of this paper is on farmers' management practices to identify possible solutions that are adapted to their locality.

\section{Material and method}

\section{Study area and research approach}

This study was performed from August to December 2006 in the Centre province of Cameroon. Four types of traditional forest gardens (TFG) in four agro-ecological zones (Ngomedzap, Bakoa, Talba and Kedia) as described in Chapter 1. Ngomedzap was considered as an extensively managed old traditional cocoa forest garden (EO), Bakoa as an extensively managed young traditional cocoa forest garden (EY), and Obala as a home garden cocoa forest (HG), because all plantations are located very close to the houses in the village. Talba was considered to be an intensively managed mature traditional cocoa forest gardens (IM) and Kedia as an intensively managed young traditional cocoa forest gardens (IY). Five Union of GICs (Common Initiative Group) and three federations were identified and selected for the study, regrouping 41 GIC with a total of 2597 cocoa farmers (Table 1).

\section{Field methods}

The survey consisted of a total of 400 cocoa farmers sampled and interviewed individually in the four zones, in a total of 5 unions around Ngomedzap, Bakoa, Talba and Kedia. During the pilot phase a pre-survey were performed with key informants and focus group discussions to access the indigenous knowledge of farmer management practices. After the pre-test, questionnaire was modified and the final version translated into French for use to interview farmers. In order to maintain consistency, questions were phrased in the way they should be asked. Four enumerators selected among cocoa farmers based on their voluntary spirit, appreciable knowledge about cocoa, commitment for the Union, level of education (generally has completed secondary school), and ability to communicate easily, patience, honesty and humility were trained on insect pests and diseases identification and damages but also to administered questionnaires during the survey. The questions addressed farmers' socio-economic background and farming 
practices and focused on gaining an understanding farmers' awareness of the ecological and economic changes brought about as a result of liberalization of the cocoa sector. Data collected included quantitative characteristics: the age of cocoa farmers, marital status, level of education, family size, cocoa farming experience, number of cocoa fields, distance of plantation from the forest, alternative sources of income and contact with extension services. Level of education was ranked as follows: 1. (less than primary school); 2. (Some primary school); 3. (Completed primary school); 4. (Attended secondary school); 5. (Completed secondary school); and 6. (Attended college or University). Cocoa farming experience was defined as the number of year farmer has been involved in the farming of cocoa. Qualitative characteristics included: pests and diseases incidence, yield, farm characteristics and management, neighbour or shading trees in plantation, associated crops with cocoa in plantation, IPM knowledge, pesticides used: constraints and preference. Farm characteristics included farm landscape, litter, herbaceous and canopy cover; and type of shading trees in the farm. Management involved pruning, shading, and coppicing time. Pesticides used were defined as both synthetics (Commercial insecticides and fungicides) and botanicals (plant extracts). The survey data were encoded, entered into SPSS sheets and verified prior to analysis. Systat 11 and SPSS (SPSS Inc, 2000) were used in the analysis.

\section{Results}

\section{Farmers’ socio-economic background}

Of the overall farmers interviewed during the study, $9 \%$ were female and $91 \%$ were male. Female accounted only for $4 \%$ in EY and $16 \%$ in EO. Female cocoa farmers were generally widowers and accounting for $100 \%$ female farmers in EY. Polygamy was mostly observed in intensive systems with $11.2 \%$ of farmers in IM and $17.7 \%$ in EY. Most farmers had a basic education with $48 \%$ (mean: 3.19 ) in IM and $46 \%$ in EO (mean: 3.13) having completed primary school education. The lowest rate of education was found in EY (mean: 2.50) (Table 2). Only 3\% farmers in IM had less than primary education compared to $13 \%$ in EY. About 3 to $5 \%$ farmers attended college or University in IM and EO respectively (Table 2). Most of the farmers could read and write. Results in 
Table 2 show that the average number of children per household is significantly different $(p=0.003)$ between systems with the highest number of children per household recorded in IM. The average age of farmers was about 47 years with older farmers recorded in EO and the younger in IY. There was a significant difference $(p=0.008)$ in the cocoa farming experience (mean: 21 years) between systems with younger experience (17 years) recorded in IY and older in EO (23 yrs) (Table 2). Farming experience and age of farmers were related $(\mathrm{F}=455.56, \mathrm{r}=0.75, \mathrm{p}=0.000)$. The farmers interviewed were typically smallholders, with farm sizes averaging 2.28 hectares/households in IY and 4.83 in IM. Number of farm was significantly different $(\mathrm{p}<0.001)$ per household between systems with households in old systems having at least two plantation fields (Table 2).

Farmers used their land to produce other major crops such as plantain/banana, maize, cocoyam, cassava, groundnut, yam and oil palm respectively. Main crops associated with cocoa as shade were banana/plantain $(43.5 \%$ of total farms) and oil palm tree $(37.5 \%)$. More than $90 \%$ of farms in intensive systems were associated with oil palm trees and plantain/banana respectively. Maize and cassava were reported to be associated with cocoa seedlings. About $83 \%$ of farmers in EO did not associate cocoa with any other crop.

\section{Farming of cocoa and farm characteristics}

Planting materials were dominated by hybrids (40\%) and the "German cocoa" cultivars (37\%) in old systems while "Tout venant" (58\%) and mixed cultivars (48\%) were the most dominant in IM and IY respectively. Type of shading trees differ significantly $(\mathrm{p}<0.001)$ between systems with 3 and $9 \%$ of farms in IY having only forest or fruit tree species for shade. When looking at location of cocoa farms between systems, there was a significance difference $(\mathrm{p}=0.000)$ in location with $83 \%$ of cocoa farms in EO and IM located near or in the forest. Farms in IY and EY were located near the village. Average number of cocoa tree per farm varies from 1629 trees/farm in IY to 4808 trees/farm in IM with mean age of trees per TFG ranging from 18.30 years in IY to 36.65 years in EO (Table 2). The number of cocoa tree was related to farm size $(F=991.68, r=0.87, p<0.001)$ as the age of cocoa trees to cocoa farming experience $(\mathrm{F}=15.53, \mathrm{r}=0.21, \mathrm{p}<0.001)$ but not to the age of farmers. Mean pods produced per tree increased significantly $(F=11.60$, $\mathrm{r}=0.18 \mathrm{p}<0.05$ ) with farming experience and varies from 14.34 pods/tree in EO to 34.15 
pods/tree in EY (Table 2). Results from farmers' perception show that litter cover range from average to low in extensive systems and from average to important in intensive ones with IY recording the lowest litter cover. The lowest herbaceous cover was also recorded in IY and the highest in EY. Herbaceous cover and litter cover were positively related $(\mathrm{F}=12.36, \mathrm{r}=0.17, \mathrm{p}<0.001)$. Most farmers' interviewed in IY (61\%) perceived the canopy cover of their farm as thin while $48 \%$ of farmers in EO reported having an important canopy cover. Agronomic practices such as pruning, coppicing and shade management are practiced after harvest or just before flowering in all systems. More than $80 \%$ of farmers in TFG prune their cocoa trees or manage shade but coppicing is just practice by $12 \%$ of farmers in IM. Tree species richness decreases significantly $(\mathrm{F}=282.10, \mathrm{r}=0.64, \mathrm{p}<0.001)$ with management regime and only trees with economy importance were selected by farmers in intensive manage systems. Family as source of manpower was reported by most farmers in extensive systems. About $40 \%$ of farmers in IY rely on mutual help as manpower. While $89 \%$ of farmers in IM employ remunerated labour either as casual $(75 \%)$ or permanent (14\%) workers.

\section{Constraints of production}

Farmer's knowledge and rank major constraints in production revealing in order pests, dieback, diseases, soil fertility and market accessibility as the most important. Among pests farmers recognized in other of importance mirids, stemborers, podborers, ants and defoliators. They also identify pods, young branches, chupons and young cocoa tree as the most preferred feeding materials of mirids. Kola (Cola nitida) was reported by farmers to be the most preferred alternative hosts of mirids (Table 3). Farmers identify the number of pods loss due to mirids or black pods. Pods loss to mirids was significantly $(\mathrm{P}<0.001)$ different between systems. There was no significant difference between systems in pod loss to black pod disease (Figure 1). Hybrids cultivar was recognized by farmers as the most susceptible cultivar to mirids (Figure 1). Other pests reported were mammals (small and large), thieves (mainly in intensive systems) birds and to some extend snakes (IM). Black pod caused by P. megakarya was identified by farmers as predominant disease of pods with rain, ants, mirids and millipedes ranked as main disseminating agents (Figure 2.). 


\section{Farmers' practices in pest and disease control}

Almost all cocoa farmers applied pesticides in their farm with farm generally treated individually except in EY where $65 \%$ of farmers treat their farm in group. About 2 to $3 \%$ of farmers in EO, EY and IY respectively do not treat their farms with pesticides. Treatments were with insecticides (62\% of farmers), fungicides (76\% of farmers) or insecticides mixed with fungicides $(28 \%)$, practice very common in intensive systems (Table 4). When asked about the contact with cocoa extension agents, the majority (68 $\%)$ of farmers never had contact with extension agents. About $44 \%$ of cocoa producers across the zone have knowledge about IPM with $37 \%$ in EO, 29\% in IY and 18\% in IM (Table 4). Ants tending activity was reported by $28 \%$ of farmers in EY and $10 \%$ IM respectively. Species tended included Oecophylla longinoda (7.5\% of total respondents), red ants $(2.5 \%$ of total respondents) and Tetramorium sp (1.75\% of total respondents). More than $20 \%$ of farmers know of indigenous methods of pest and disease control. About half of those who know about the methods use one of them with precision. The figure was 50\% in EO and IM respectively, $31 \%$ in IY and $12.5 \%$ in EY. Botanicals was the most indigenous methods of pest control known by farmers and was used mainly as crude extracts $(69 \%$ in EO) or mixed with insecticides $(50 \%$ in IY), fungicides $(31 \%$ EO) or with insecticides + fungicides (45\% in IM and $14 \%$ in EY). Hemp (Canabis sativa) accounted for $49 \%$ of total botanicals used by farmers (Figure 3). Hemp seeds were reported as the most efficient part against mirids while leaves and stems were recognized by farmers as the most efficient against black pods. The average type of commercial insecticides applied differs significantly between management systems and increased significantly $(\mathrm{P}<0.001)$ with increasing intensification (Figure 3$)$.

More than $29 \%$ of farmers who used indigenous methods reference the ban of hemp as a problem. The figure is $20 \%$ in EO, $36 \%$ in IY, $25 \%$ in EY and IM respectively. Health hazards, scarcity of some ingredients, and the methods being labor intensive were mentioned by $17 \%$ of farmers who use the method respectively. Of farmers who use the indigenous methods, $9 \%$ think that indigenous methods are more effectives than modern ones and $50 \%$ think both methods are effective. Only $9 \%$ of farmers prefer indigenous methods to moderns ones while $65 \%$ prefer both methods. Of those who never use indigenous methods, $53.5 \%$ prefer only modern methods and $46 \%$ had no opinion as yet (Table 5). 


\section{Inputs, yield assessment and alternative source of income}

Cost of labour and cost of pesticides was six and three fold respectively higher in IM than other systems. Mean number of cocoa bags harvested per year was four fold higher in intensive manage old system than extensive ones. Yield per hectare decrease with decreasing management with average yield per hectare being $349.32 \mathrm{~kg} / \mathrm{ha}$. IM recorded $547.48 \mathrm{~kg}$ of cocoa beans per hectare and EY $215.58 \mathrm{~kg}$ of cocoa beans per hectare (Figure 4). The highest quantity of fruits other than cocoa sold per year by farmers was reported by farmers in IY (Table 6). Average net income per farmer was lower in the old manages systems than the young manage ones (Fig. 4). Other source of income included palm wine tapping ( $7 \%$ in IY, $9 \%$ of farmers in EO, and $41 \%$ in EY), pension (4\% of farmers in IM, 5\% in EY, 7\% in EO, and 8\% in IY respectively), logging (1\% in IM and $4 \%$ in EO), rent from houses (3\% in EO), animal breeding (1\% in IY, $6 \%$ in EO and EY respectively and 7\% in IM) and trading (13\% in EO, 16\% in IM and 30\% in IY).

\section{Discussion}

This study was performed in an attempt to listen to farmers in order to develop a participatory program of integrated management of traditional cocoa forest gardens (TFG). The results show that management practices in the four groups of traditional cocoa forest gardens are influenced by socio-economic, technical or biological and environmental parameters. Groups were classified based on farmers' socio-economic characteristics and farms abiotic and biotic characteristics. The population of the study areas consists of farmers and the economy is based on agriculture where about $95 \%$ of the inhabitants are cocoa farmers who also grow food crops for subsistence. However,

they sometimes sell food crops to meet minor domestic expenses. The results from this study confirmed that cocoa is their main source of income. The income from cocoa enables farmers to build new houses or repair existing ones. At the personal level, some of the farmers are able to save enough money from cocoa to invest in trading, transport or to pay the dowry needed to marry a woman. Cocoa production is dominated by men; women are generally involved in time-consuming operations such as harvesting, opening the pods or fetching water for mixing chemicals. Although the involvement of women 
and other family members in cocoa cultivation is well established, little attention has been paid to promoting the crop as a possibility for empowering rural women. However, a study by the International Food Policy Research Institute (IFPRI) suggests that "cultivating cocoa provides women with economic security and a more secure way to gain rights to land" (IFPRI 2002). Involving more women in the management of TFG is one way of achieving sustainable production and social balance in the cocoa sector (Losch et al. 1991; Sonwa et al. 2001). The age of cocoa trees was not related to the age of farmers because more than half of cocoa farms were inherited by the current owner. In southern Cameroon planting a tree on a plot gives the right of ownership and usufruct over that plot. Cocoa plantations are therefore passed down from generation to generation, from father to son.

After the economic and cocoa crisis (Coulibaly et al. 2002) cocoa farmers in Cameroon have become independent decision makers in agriculture. Most farmers or their organization's now make their own decisions about what to plant, what cultivars or varieties to use. In this way, cocoa farmers in Cameroon are similar to smallholder farmers in other developing countries. Farmers have developed methods in plant breeding and protection based on observational skills. Local cultivars ("Tout venant" and mixed materials) were developed and are more satisfactory than hybrids provided by the extensions before the crisis.

The Number of pod per tree responded positively to litter layer and litter layer was related to herb layer. Fertilizers are not use by farmers in TFGs therefore having an important herbaceous cover may contribute significantly in increasing production. Important herbaceous cover will provide a more heterogeneous habitat and resources to soil biota (decomposers and endophytic fungi). Plantations near the village recorded a significant lower tree species richness and density and higher number of pods loss to mirids and $P$. megakarya. Higher tree species richness and density provide more heterogeneous habitat and resources to predators and parasitoids. Klein et al. (2002) showed that the predator-prey ratio was reduced with land-use intensity when studying tropical cacao systems and natural forests. Parasitoids family richness (Sperber et al. 2004) and predator species richness (Ribas et al. 2003) were shown to increase with tree species richness and density reflecting increasing heterogeneity and availability of resources. Beattie (1985) suggested that plants that attract a diversity of predators would 
be advantaged due to the variety of herbivores that would be controlled. Therefore indiscriminate felling of forest trees on the cocoa farms should be stopped. Loss to black pods was not related to tree species richness or density suggesting other interactions playing such as disseminating agents. We observed that cocoa farmers have in-depth knowledge of some common pests and diseases as well as their mode of dissemination. An example is the black pod disease where farmers admitted receiving advice on chemical control as well as agronomic practices like shade management to reduce humidity or infected pod removal (Ndoumbè et al., 2004), they were also able to identify their mode of dissemination and to explain and appreciate the direct benefit of adopting certain practices. Our results suggest that farmers are very well knowledgeable on phenomenon in nature they can easily observe while less obvious ones may escape their attention (Bentley, 1992; Van Huis and Meerman, 1997). Millipede as a significant disseminating agent of black pods was recognized by farmers and need to be addressed by researchers. Hybrid cultivars, although having the highest productivity, were reported by farmers to be more susceptible to mirids than black pods while farmers recognized the "German cocoa" to be the most resistant. This is probably because when breeding hybrids emphasis was placed on higher pods production and resistance to P. megakarya than $S$. singularis. Most farmers are reluctant to plant the "German cocoa" despite being resistant to mirids and black pods because of its low productivity (only one production per cropping season compare to two with hybrids and others cultivars locally developed) and high production cost. There was a significant difference between pods loss to mirids and pods loss to black pods disease suggesting mirids to be an important limiting factor in production. At the beginning of the study, most farmers were not able to identify the mirids species $S$. singularis (SS), except two farmers in the intensive systems, but all of them recognized the Cocoa Mosquito (Heliopeltis sp). But after a short training on insect pest of cocoa, they were able to identify preferred feeding materials and alternative host of SS and their devastating effect on young cocoa plants. We can conclude that suitable rural education based on discovery learning, could help farmers to acquire basic skills and understanding in identifying the insects pests on their cocoa and developing confidence in the effectiveness of integrated pest management strategies.

Dieback was reported by farmers as the second important constraint in production increasing significantly with increasing land-use management suggesting an increasing 
level of anthropogenic disturbances and alteration of habitat of natural enemies of the incriminated pathogen. Continuous removal of trees from TFGs could result in a significant biodiversity loss and pest and diseases outbreaks. Although there is no study documenting the role of biodiversity in preventing disease outbreaks, Perfecto and Castiñeira (1998) suggested that diverse insect communities can offer better protection against pest outbreaks than communities dominated by fewer species. Knowledge of IPM and/or contact with extension services (mainly from IRAD "Institut de la recherche Agricole pour le Développement, Cameroun" and IITA “International Institute of Tropical Agriculture") may contribute in reducing pod loss to mirids and $P$. megakarya and improving yield. IPM was recently introduced in farmers' organizations through farmer field school (Sustainable Tree Crop Program, IITA) and participatory workshop (IRAD, Sustainable and Competitive Cocoa Systems) after the liberalization of cocoa sectors.

In response to the high price of inputs and the low price of cocoa, some farmers modify the input recommendations, while other decided not to apply any inputs at all. This involves mixing of insecticides or fungicides with plant extracts. The farmers believe that this mixing increases the effectiveness of the chemicals and improve yield. Herbicides are not often used in cocoa plantations explaining why very few indigenous weed control methods (other than slashing) have been developed. According to farmers, indigenous methods are effective against several problems at the same time and allow reducing the number of treatments. Botanicals, as crude extracts are used by farmers against mirids and P. megakarya with different degree of satisfaction. This could be explained by the fact that the response of insects to toxic effects of secondary metabolites depends on their size, age and physiological status (Busvine, 1971). Also, variation in the toxicity of the crude extracts from plants species used by farmers could be attributed to loss of some toxic volatile constituents through volatilization during drying and or extraction couple with the uniqueness of various plant parts with regards to their secondary metabolites justifying difference in activity of plant parts used, the mixing of crude extracts with synthetic chemicals and the preference of both methods by farmers. Plants used depend on its natural availability and the proximity of the forest. The ban on some plant used was mentioned by some farmers who use indigenous control methods. C. sativa is the most used plant by farmers despite the legal ban on its use. Farmers' prefer running the risk of breaking the law by using the plant in treating their cocoa plantations, rather than leaving 
their plantation vulnerable to pests. The finding of other plants with the same active ingredients as Cannabis should overcome the farmers' dependence on the illegal plant. Regarding the scarcity of some ingredients as mentioned by some farmers, high value timber species such Pterocarpus soyauxii, Guibourtia tessmannii and Erythrophleum ivorense, of which the bark is reported to be used by farmers for pests and disease control and in traditional medicines and are logged for their wood could be planted in TFGs. Planting such trees in TFGs will provide shade as well as financial income for the farmers from the sale of the wood and the ingredients can be used in integrated control methods. Reforestation of TFGs will increase habitat heterogeneity and provide social and economic benefits to households without adverse effects on the environment. Identifying sources with useful biological activity is only the starting point in the long process of developing a botanical pest management product. There is the necessity to identify and standardize the active ingredient of botanicals but also availability of the natural resource, adequate biomass to justify extraction, the feasibility of extraction near the harvest site, variation in seasons for collection of plant materials, and the stability of the extract in storage after preparation are to be considered as well as health hazards and safety risks.

The low yield as observed may be due to the age of cocoa farmers', low soil fertility and to some extend the lack of social amenities like electricity. Most of the villages surveyed and their surrounding do not have access to the electricity and have poor road facilities. Previous studies by Dormon et al. (2004) showed a positive relationship between the lack of electricity and youth migration to the cities. Youth migration creates labour shortage, leading to high labour costs. Youth migration also leaves the aged farmers in the village to take care of the farms. Cocoa production requires many cultural practices that are labour intensive: about four weeding rounds per year, removal of mistletoes and other epiphytes, shade management through pruning, and removal of basal suckers. In addition to the cultural practices farmers should performed other labour intensive activities like harvesting, opening the pods, fermenting and drying the beans. The labour requirements for cocoa production to date are summarized by Dormon et al. (2004). There are two options for cocoa farmers in southern Cameroon if he/she wants to meet his requirements, either to hire labour or to rely on family labour. The costs of hired labour are out of reach of most farmers or they are not willing to invest capital in labour. The higher labour 
requirement for young cocoa farms in combination with the labour shortage contributes to the difficulties farmers face in replacing their old cocoa farms as observed in extensive manage old TFGs. It was observed that $72 \%$ of the labour on cocoa farms not employing permanent labour is from the farmer, his/her spouse, children and other dependents. Therefore, the current out-migration of the youth from their village to the cities due to lack of social amenities like electricity has aggravated the labour scarcity problem. On the other hand, the attractive high cost of labour in intensive mature TFGs (between 5 to 7 US\$ per Labour Day) has attracted a lot of migrants from the northwestern (at about $550 \mathrm{~km}$ ) and neighbouring Adamaoua provinces making this area a leader in cocoa production in southern Cameroon. However, mutual help as observed in intensive young system could be an alternative to youth migration and promoted in other systems.

Before the liberalization of the cocoa sector, the State use to fix at the beginning of each campaign the purchase price to the farmer's base on quality. This practice has completely disappeared since 1995 and today the purchase price is based on the price at the international market after deduction of transaction charges. It is observed that the purchase prices from cocoa farmers within the surveyed areas vary significantly between

old and young systems with extensive young system recording the lowest purchasing price. This factor may be attributed to the low yield and consequently low volume of cocoa beans available for buyers who generally pay higher price when the volume of beans available is considerable. The low yield observed in this system is a consequence of the age of cocoa trees (the system recorded the highest age of trees) and low soil fertility (higher proportion of farmers in the locality reported soil fertility as a main constraint). In addition to cocoa beans sold, exotic fruits and NTFPs provide an additional average income to farmers.

\section{Conclusion}

From this study it can be concluded that the cocoa farmers described a complex situation in which a range of abiotic and biotic factors constrained their cocoa-based livelihoods. They mentioned technical or biological, institutional and socio-economic production constraints. Technical problems relate to pest damages and diseases and low soil fertility, whereas institutional and socio-economic problems relate to low price of cocoa, 
expensive inputs, lack of labour and lack of technical assistance. It was observed that these two categories of causes are closely inter-related with an impact on yield. Cocoa farmers in southern Cameroon in many respects were similar to most traditional smallscale farmers in developing countries with average comprehension of the key variables in sustainable pest and disease management. They are knowledgeable about their problems and can be principal actors in the process of technology development through an educational system that combines aspects of Western technical knowledge with local knowledge. The relative high literacy among Cameroonian cocoa farmers offers the potential for the use of written media in sensitization efforts. The farmers managing biodiversity at farm level will help reducing pest and disease incidence while improving yield and sustainability of TFGs. Research has paid little attention to farmers' demands as have the extension services and it time to wok together with farmers in improving indigenous methods of plant breeding and protection as well as helping farmers to understand mechanisms regulating above and below ground multitrophic interactions in TFGs. Local knowledge is often region specific and recommendations must be adapted to each producing area. Our study has identified potential areas that researchers and policy makers need to focus their attention to, to facilitate the development of coherent innovations. Introducing high-yielding varieties or encouraging specific pest and disease control strategies is likely to yield limited success if some important social and technical issues are not respected. Such issues include electricity, out-migration and labour shortages, road facilities, access to credit and capacity building of farmer organizations. Solutions for high productivity of cocoa in southern Cameroon will rely on a coherent package of social and technical solutions.

\section{Acknowledgments}

We thank the University of Goettingen (IPAG "International PhD Programme in Agricultural Sciences in Goettingen" and Entomology section) for financial support. Enumerators and key informants from farmers' organizations surveyed. 


\section{References}

Beattie, A. (1985) The evolutionary ecology of ant-plant mutualisms. Cambridge University Press, Cambridge.

Bentley, J.W. (1992) The epistemology of plant protection: Honduras campesinos knowledge of pests and natural enemies. In: Gibson, R. W. Gibson., Sweetmore, A. (Eds.), Proc. of a Semi. On Crop Protec. for Resource-Poor Farmers, National Resources Institute (NRI), Chatham, pp. $107-118$.

Bruin, G., Meerman, F. (2001) New ways of developing agricultural technologies: The Zanzibar experience with participatory Integrated Pest Management. Wageningen University, Wageningen, 167pp.

Busvine, JR. (1971) A critical review of the techniques for testing insecticides. CAB. $345 \mathrm{pp}$.

Coulibaly, O., Mbila, D., Sonwa, DJ., Adesina, A., Bakala, J. (2002) Responding to economic crisis in sub-saharan Africa: New farmer-developed pest management strategies in cocoa-based plantations in Southern Cameroon. Int. Pest Manage. Rev. 7, 165-172.

Dormon, E.N.A., Van Huis, A., Leeuwis, C., Obeng-Ofori, D., Sakyi-Dawson, O. (2004) Causes of low productivity of cocoa in Ghana: farmer's perspectives and insights from research and the socio-political establishment. NJAS - Wagen. J. of Life Sci. 52, 237 259.

Gregory, PH., Griffin, MJ., Maddison, AC., Ward, MR. (1985) Cocoa Growers Bull 35, 2-8. 
IFPRI (2002) Empowering women and fighting poverty. Cocoa and land rights in West Africa 7pp.

Klein AM., Steffan-Dewenter, I., Tscharntke T. (2002) Predator-prey ratios on cocoa along a land-use gradient in Indonesia. Biodivers. and Conserv. 11. 683-693.

Losch, B., Fusillier, JL., Dupraz, PO., Ndjoya, J. (1991) Stratégies de producteurs en zone caféière et cacaoyères du Cameroon : Quelles adaptations à la crise ? Collection DSA. 12, 252pp.

Mpé, JM. (2002) Integrated management of cocoa mirids in Cameroon. In: Vos, J. and Neuenschwander, P. (Eds.), Proc. West Afr. Reg. Cocoa IPM Workshop, Cplpress, pp39.

Nboumbè-Nkeng, M., Cilas, C., Nyemb, E., Nyasse, S., Bieysse, D., Flori, A., Sache, I. (2004) Impact of removing diseased pods on cocoa black pod caused by Phytophthora megakarya and on cocoa production in Cameroon. Crop Protec. 23, 415-424.

Nyasse, S., (1992) Structure d'une population de Phytopthora sp. des cacaoyères camerounaises atteintes de pourriture brune. DRU Sciences agronomiques, Inst. Nat. Polytchn. De Toulouse.

Opoku, IY., Akrofi, AY., Appiah, AA. (2002) Shade trees are alternative hosts of the cocoa pathogen Phytophthora megakarya. Crop Protec. 21, 629-634.

Perfecto, I., Castiñeira, A. (1998) Deployment of the predaceous ants and their conservation in agroecosystems. In: Barbosa, P. (Eds.), Conservation biological control. Academic Press, New York, pp. 269-289.

Ribas, CR., Schoereder, JH., Pic, M., Soares, SM. (2003) Tree heterogeneity, resource availability, and larger scale processes regulating arboreal ant species richness. Austral Ecol. 28, 305-314. 
Röling, N.G. (1996) Towards an interactive agricultural science. Euro. J. of Agric. Edu. And Ext. 2(4), 35 - 48.

Sonwa DJ., Coulibaly, O., Adesina, A., Weise, SF., Tchatat, M. (2002) Integrated pest management in cocoa agroforest in southern Cameroon: Constraints and overview. Int. Pest Manage. Rev. 7 191-199.

Sperber, CF., Nakayama, K., Valverde, MJ., Neves, FS. (2004) Tree species richness and diversity affect parasitoid diversity in cacao agroforestry. Basic and Appl. Ecol. $\underline{5}, 241-$ 151.

SPSS Inc. (2000) Systat 11 for Windows. SPSS Inc., Chicago

Van Huis, A., Meerman, F. (1997) Can we make IPM work for resource-poor farmers in sub-Saharan Africa? Int. J. of Pest Manage. 43, 313 - 320. 


\section{List of Figures}
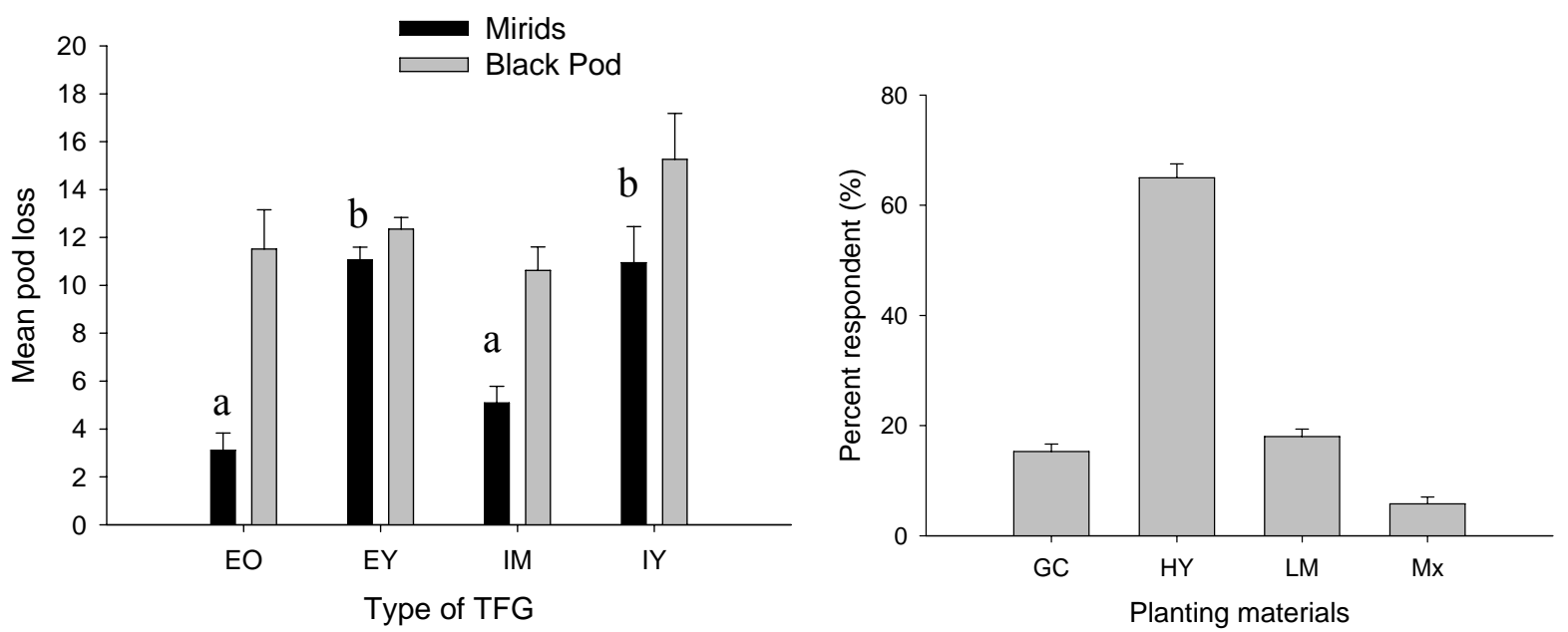

Figure 1. Analyses of parameters influencing productivity in TFGs based on mirids, black pod disease (left) and susceptible varieties to mirids (right). Significant difference was observed between pods loss to mirids in TFGs and no significant difference between pods loss to black pod diseases in TFGs. EO - Extensive manage old cocoa forest gardens; EY - Extensive manage young cocoa forest gardens; IM - Intensive manage mature; IY - Intensive manage young; GC: German cocoa; HY: Hybrids cocoa plant materials; LM: Local cocoa plant materials; Mx: Mixed cocoa plant materials (see text for details).

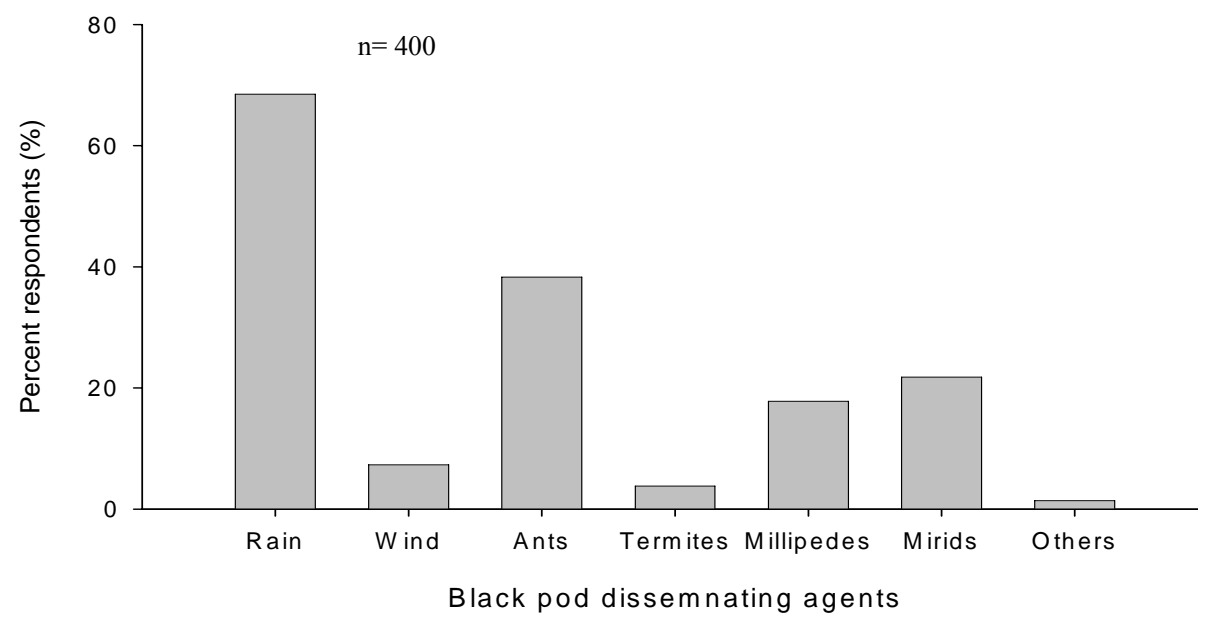

Figure 2. Farmers' perception of black pod disseminating agents in traditional cocoa forest gardens in southern Cameroon 

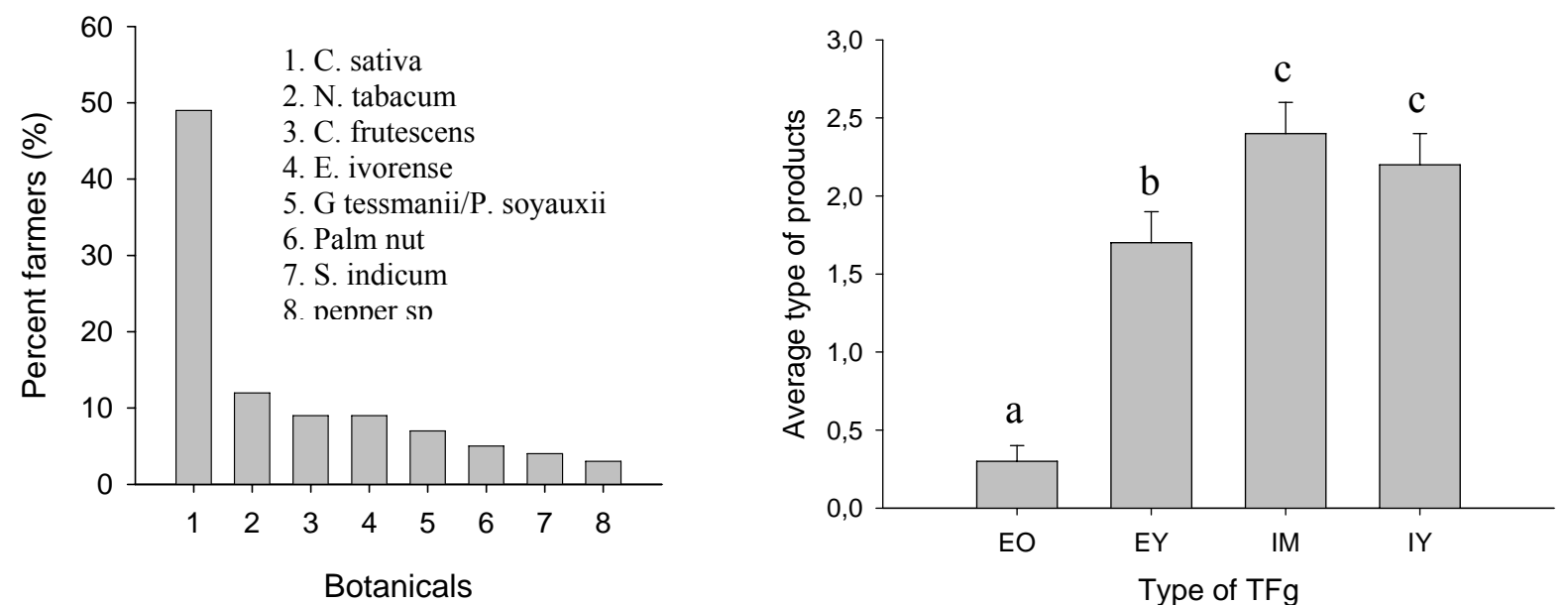

Figure 3. Farmers' record of botanicals (left) and number of commercial insecticides (right) used against pests and diseases. EO: extensive old; EY: extensive young; IO: intensive old; IY: intensive young.
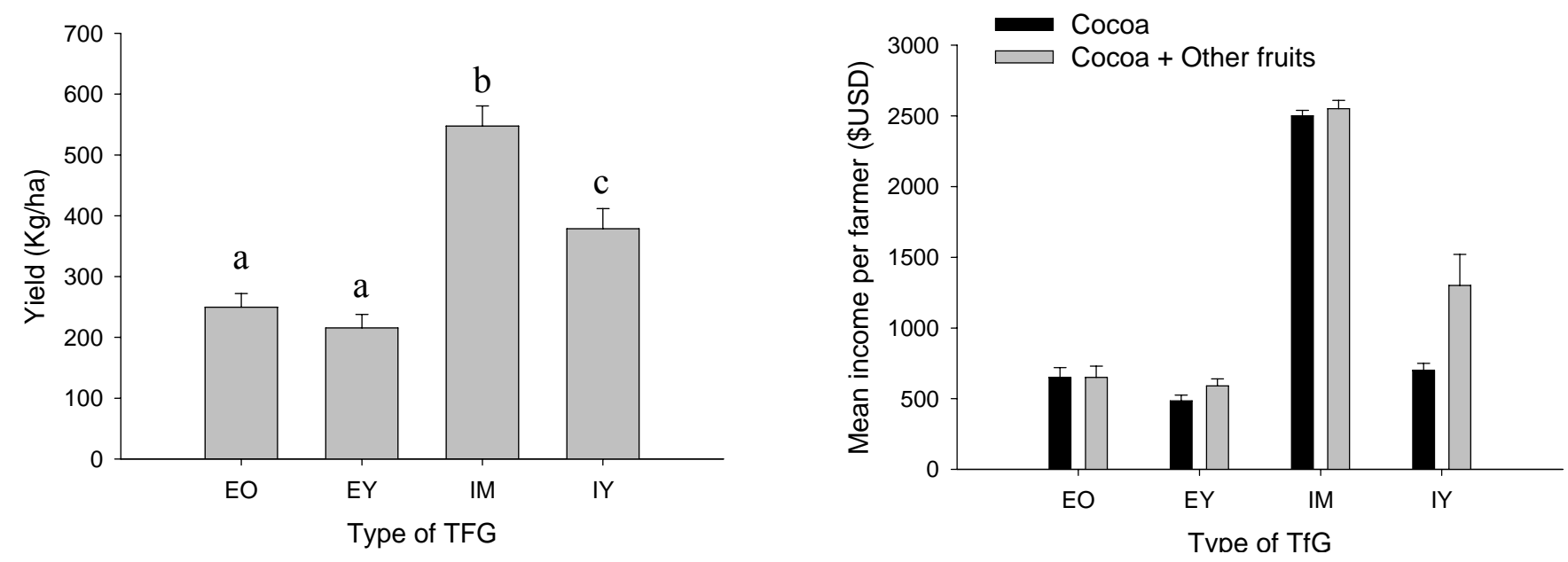

Figure 4. Yield of cocoa as $\mathrm{kg} / \mathrm{ha}$ (left) according to farmers perception and average income from cocoa and other fruits sold per farmers (right) in TFG. . EO - Extensive manage old cocoa forest gardens; EY - Extensive manage young cocoa forest gardens; IM - Intensive manage mature cocoa forest gardens; IY - Intensive manage young cocoa forest gardens. 


\section{List of Tables}

Table 1. Cocoa farmer's organizations selected for the study

\begin{tabular}{|c|c|c|c|}
\hline Locality & Federation & \multicolumn{2}{|c|}{ Union } \\
\hline \multirow[t]{3}{*}{ Ngomedzap } & FUPROCAN & UGISET & UGICAABO \\
\hline & & $5 \mathrm{GIC}-213$ & $5 \mathrm{GIC}-120$ \\
\hline & & Farmers & Farmers \\
\hline \multirow[t]{3}{*}{ Kedia } & FUPROCAM & UGIKAKED & \\
\hline & & $4 \mathrm{GIC}-114$ & \\
\hline & & Farmers & \\
\hline \multirow[t]{3}{*}{ Bakoa } & FUPROCAM & UGICABO & \\
\hline & & $17 \mathrm{GIC}-950$ & \\
\hline & & Farmers & \\
\hline \multirow[t]{3}{*}{ Talba } & FUPROCATS & UGICATS & \\
\hline & & $14 \mathrm{GIC}-1200$ & \\
\hline & & Farmers & \\
\hline
\end{tabular}


Table 2. Socio-economic background of the surveyed cocoa farmers

\begin{tabular}{|c|c|c|c|c|c|}
\hline & \multicolumn{4}{|c|}{ Traditional cocoa forest gardens (Mean \pm SD) } & \multirow[b]{2}{*}{ pValue } \\
\hline & EO & EY & IM & IY & \\
\hline Age of farmers & $50.84 \pm 15.89^{c}$ & $45.54 \pm 13.18^{\mathrm{ab}}$ & $48.88 \pm 8.96^{\mathrm{bc}}$ & $43.07 \pm 11.08^{\mathrm{a}}$ & $\mathrm{p}<0.001$ \\
\hline Education level & $3.13 \pm 1.20^{\mathrm{b}}$ & $2.50 \pm 0.99^{\mathrm{a}}$ & $3.19 \pm 1.06^{\mathrm{b}}$ & $3.07 \pm 1.17^{\mathrm{b}}$ & $\mathrm{p}<0.001$ \\
\hline Number of children & $5.81 \pm 5.22^{b}$ & $5.47 \pm 3.84^{b}$ & $6.53 \pm 3.15^{\mathrm{b}}$ & $4.92 \pm 3.14^{\mathrm{a}}$ & $\mathrm{p}<0.05$ \\
\hline Farming experience & $22.71 \pm 14.76^{\mathrm{b}}$ & $20.87 \pm 11.64^{\mathrm{b}}$ & $21.26 \pm 8.64^{\mathrm{b}}$ & $17.30 \pm 9.80^{\mathrm{a}}$ & $\mathrm{p}<0.05$ \\
\hline Number of farms & $2.01 \pm 1.19^{b}$ & $2.03 \pm 0.89^{b}$ & $1.34 \pm 0.59^{\mathrm{a}}$ & $1.34 \pm 0.59^{\mathrm{a}}$ & $\mathrm{p}<0.001$ \\
\hline Farm size (ha) & $2.63 \pm 0.26^{\mathrm{a}}$ & $2.76 \pm 0.19^{\mathrm{a}}$ & $4.83 \pm 0.34^{\mathrm{a}}$ & $2.28 \pm 0.16^{\mathrm{a}}$ & $\mathrm{p}<0.001$ \\
\hline Number of tree/farm & $2752 \pm 226.75^{\mathrm{b}}$ & $2408 \pm 135^{b}$ & $4808 \pm 277^{\mathrm{c}}$ & $1629 \pm 117^{\mathrm{a}}$ & $\mathrm{p}<0.001$ \\
\hline Age of trees & $36.65 \pm 4.10^{\mathrm{b}}$ & $51.77 \pm 1.98^{\mathrm{c}}$ & $20.39 \pm 0.88^{\mathrm{a}}$ & $18.30 \pm 1.14^{\mathrm{a}}$ & $\mathrm{p}<0.001$ \\
\hline Pods produced/tree & $14.34 \pm 4.10^{\mathrm{a}}$ & $34.15 \pm 2.73^{c}$ & $33.25 \pm 3.04^{\mathrm{c}}$ & $28.42 \pm 3.39^{\mathrm{b}}$ & $\mathrm{p}<0.001$ \\
\hline
\end{tabular}

NB: No significance difference between same letters within rows; EO - Extensive manage old cocoa forest gardens; EY - Extensive manage young cocoa forest gardens; IM - Intensive manage mature cocoa forest gardens; IY - Intensive manage young cocoa forest gardens 
Table 3. Farmers' recognition of constraints associated with production, main pests and alternative hosts of mirids (total respondents per $\mathrm{TFG}=100$ ).

\section{Traditional forest gardens (\%)}

\begin{tabular}{|c|c|c|c|c|c|}
\hline Variables & $\mathrm{EO}$ & EY & IM & IY & pValue \\
\hline \multicolumn{6}{|c|}{$\begin{array}{l}\text { Constraints of production ( } \% \text { total } \\
\text { respondents) }\end{array}$} \\
\hline Pests & $94^{\mathrm{a}}$ & $100^{\mathrm{b}}$ & $100^{\mathrm{b}}$ & $100^{\mathrm{b}}$ & $\mathrm{p}<0.001$ \\
\hline Dieback & $54^{\mathrm{a}}$ & $90^{\mathrm{b}}$ & $100^{\mathrm{b}}$ & $91^{\mathrm{b}}$ & \\
\hline Diseases & $40^{\mathrm{a}}$ & $98^{\mathrm{b}}$ & $99^{\mathrm{b}}$ & $89^{\mathrm{b}}$ & \\
\hline Soil fertility & $19^{\mathrm{b}}$ & $89^{c}$ & $21^{\mathrm{b}}$ & $39^{\mathrm{a}}$ & \\
\hline Varieties grown & $4^{\mathrm{a}}$ & $2^{b}$ & $19^{a}$ & $18^{\mathrm{b}}$ & \\
\hline Marketing & $7^{\mathrm{b}}$ & $75^{\mathrm{a}}$ & $2^{b}$ & $1^{\mathrm{b}}$ & \\
\hline Others & $1^{\mathrm{b}}$ & $0^{\mathrm{b}}$ & $0^{\mathrm{b}}$ & $7^{\mathrm{a}}$ & \\
\hline \multicolumn{6}{|l|}{ Main pests ( $\%$ total respondents) } \\
\hline Mirids & $59^{\mathrm{a}}$ & $100^{\mathrm{b}}$ & $100^{\mathrm{b}}$ & $98^{\mathrm{b}}$ & $\mathrm{p}<0.001$ \\
\hline Stemborers & $76^{\mathrm{b}}$ & $97^{\mathrm{b}}$ & $85^{\mathrm{a}}$ & $93^{\mathrm{b}}$ & \\
\hline Podborers & $76^{\mathrm{b}}$ & $99^{d}$ & $15^{\mathrm{a}}$ & $89^{\mathrm{c}}$ & \\
\hline Ants & $8^{\mathrm{a}}$ & $74^{\mathrm{c}}$ & $48^{\mathrm{b}}$ & $46^{\mathrm{b}}$ & \\
\hline Defoliators & $23^{\mathrm{a}}$ & $34^{\mathrm{a}}$ & $27^{\mathrm{a}}$ & $73^{b}$ & \\
\hline Termites & $10^{\mathrm{b}}$ & $0^{\mathrm{a}}$ & $28^{\mathrm{c}}$ & $32^{\mathrm{c}}$ & \\
\hline Root feeders & $7^{\mathrm{a}}$ & $1^{\mathrm{a}}$ & $9^{a}$ & $24^{\mathrm{b}}$ & \\
\hline \multicolumn{6}{|l|}{$\begin{array}{l}\text { Damage of mirids ( } \% \text { total } \\
\text { respondents) }\end{array}$} \\
\hline Pods & $48^{\mathrm{a}}$ & $100^{\mathrm{b}}$ & $94^{\mathrm{b}}$ & $94^{\mathrm{b}}$ & $\mathrm{p}<0.001$ \\
\hline Twigs & $25^{\mathrm{a}}$ & $99^{\mathrm{b}}$ & $50^{\mathrm{a}}$ & $57^{\mathrm{a}}$ & \\
\hline Chupons & $14^{\mathrm{a}}$ & $93^{\mathrm{c}}$ & $50^{\mathrm{d}}$ & $69^{\mathrm{b}}$ & \\
\hline Other trees & $6^{\mathrm{a}}$ & 91 & 54 & 63 & \\
\hline Young cocoa tree & 26 & $84^{\mathrm{b}}$ & $41^{\mathrm{c}}$ & $62^{\mathrm{b}}$ & \\
\hline \multicolumn{6}{|c|}{$\begin{array}{l}\text { Alternative host of mirids ( } \% \text { total } \\
\text { respondents) }\end{array}$} \\
\hline Cola nitida (Kola) & 8 & 83 & 47 & 46 & \\
\hline Adansonia digitata (Baobab) & 0 & 85 & 16 & 38 & \\
\hline Ceiba pentandra (Fromager) & 1 & 32 & 7 & 11 & \\
\hline Others & 1 & 0 & 3 & 9 & \\
\hline Desplatsia dewevrei & 0 & 0 & 4 & 1 & \\
\hline
\end{tabular}

NB: No significance difference between same letters within rows; EO - Extensive manage old cocoa forest gardens; EY - Extensive manage young cocoa forest gardens; IM - Intensive manage mature cocoa forest gardens; IY - Intensive manage young cocoa forest gardens. 
Table 4. Farmers' perception of their relationship with extension services and how farms are treated (total respondents per $\mathrm{TFG}=100$ )

Traditional forest gardens $(\%)$

\begin{tabular}{|c|c|c|c|c|c|c|}
\hline Variables & EO & EY & IM & IY & Mean & pValue \\
\hline \multicolumn{7}{|l|}{ Contact with extension } \\
\hline (\% total respondents) & $\mathrm{b}$ & $\mathrm{a}$ & $\mathrm{c}$ & $\mathrm{a}$ & & \\
\hline Never & 63 & 89 & 23 & 95 & 67.5 & $\mathrm{p}<0.001$ \\
\hline Less Frequent & 21 & 10 & 40 & 01 & 18.8 & \\
\hline Frequent & 13 & 1 & 28 & 00 & 10.8 & \\
\hline Very frequent & 3 & 0 & 9 & & 3.0 & \\
\hline Knowledge of IPM & $\mathrm{b}$ & $\mathrm{a}$ & $\mathrm{c}$ & bc & & $\mathrm{p}<0.001$ \\
\hline Yes & 37 & 80 & 18 & 29 & 41 & \\
\hline No & 63 & 20 & 82 & 71 & 59 & \\
\hline \multicolumn{7}{|l|}{ Type of treatment $(\%$} \\
\hline Insecticides & $19^{\mathrm{a}}$ & $91^{\mathrm{c}}$ & $56^{\mathrm{b}}$ & $81^{\mathrm{c}}$ & 62 & $\mathrm{p}<0.001$ \\
\hline Fungicides & $98^{\mathrm{b}}$ & $90^{b}$ & $54^{\mathrm{a}}$ & $61^{\mathrm{a}}$ & 76 & $\mathrm{p}<0.001$ \\
\hline Insecticides + Fungicides & $3^{\mathrm{a}}$ & $18^{\mathrm{b}}$ & $46^{\mathrm{c}}$ & $44^{\mathrm{c}}$ & 28 & $\mathrm{p}<0.001$ \\
\hline
\end{tabular}

NB: No significance difference between same letters between columns or letters within rows; EO - Extensive manage old cocoa forest gardens; EY - Extensive manage young cocoa forest gardens; IM - Intensive manage mature cocoa forest gardens; IY - Intensive manage young cocoa forest gardens 
Table 5. Farmers' opinion on modern methods and indigenous methods of pest and disease control.

\section{Traditional forest gardens $(\%)$}

Variables

Summary of response

Constraints of indigenous methods (IM)

(\% total respondents)

Some plants used are banned

Methods are time consuming

Methods are too expensive

6

Methods are labour intensive

Some ingredients are scarce

Health hazard

Other problems

Comparison of methods

Indigenous methods more effective 9

Modern methods more effective $\quad 41$

Both methods are effective $\quad 50$

Do not know 6

Preference of methods

Only indigenous methods 9

Only modern methods $\quad 28$

Both methods $\quad 69$

With those who do not use IM

Only modern methods

Both methods

0.5

No opinion 
Table 6. Economic parameters associated to productivity in TFG

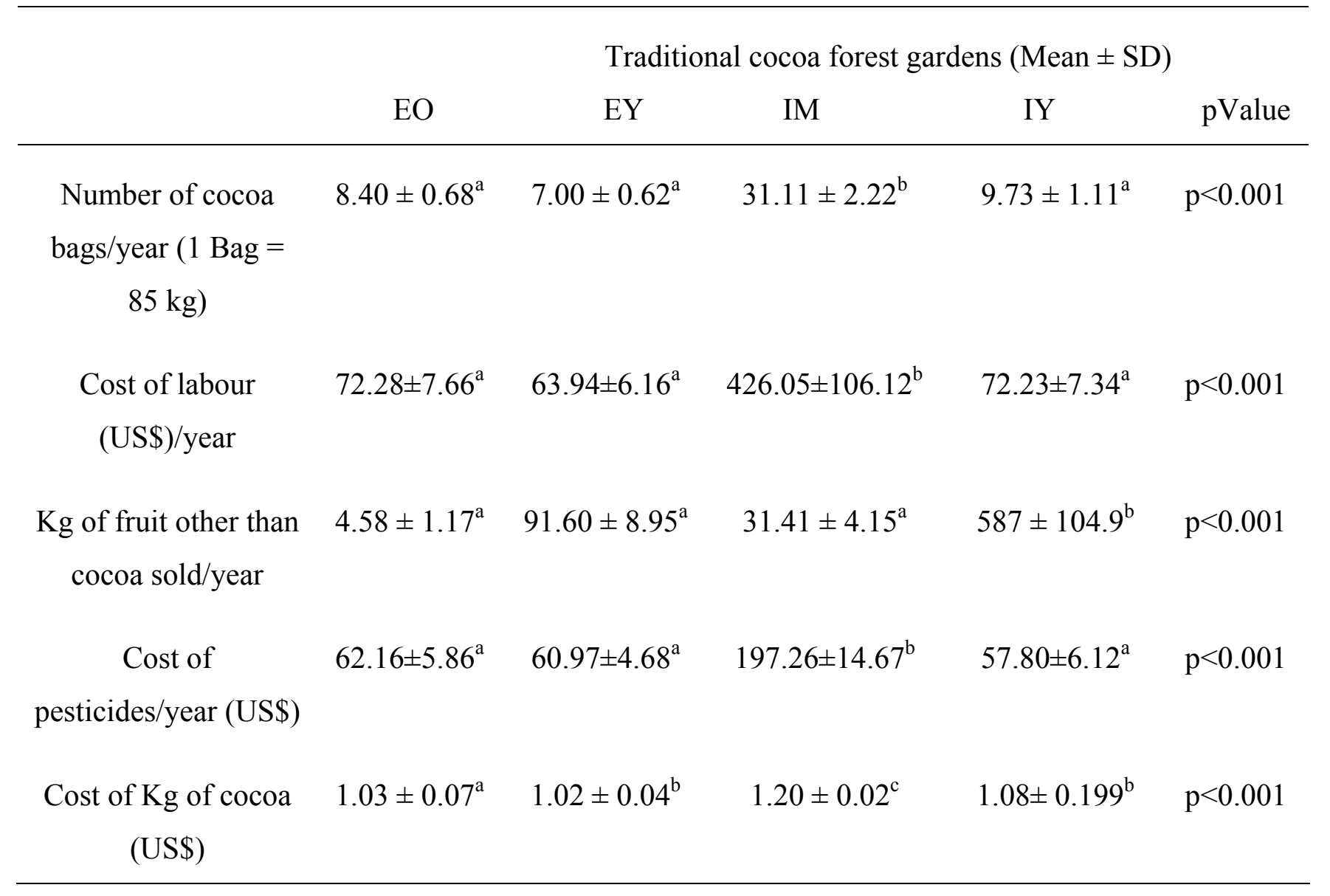

No significance difference between same letters within rows; $1 \mathrm{US} \$=500 \mathrm{CFA} ; 1 \mathrm{Kg}$ of fruit $=500 \mathrm{FCA} ; \mathrm{EO}-$ Extensive manage old cocoa forest gardens; EY - Extensive manage young cocoa forest gardens; IM - Intensive manage mature cocoa forest gardens; IY - Intensive manage young cocoa forest gardens. 


\title{
Women Perception of traditional cocoa forest garden management in southern Cameroon
}

\author{
${ }^{1,2}$ Hervé D. B. Bisseleua and ${ }^{1}$ Stefan Vidal \\ ${ }^{1}$ Georg-August-University Goettingen, Department of Crop Sciences, Entomological \\ Section, Grisebachstr. 6, 37077 Goettingen, Germany; ${ }^{2}$ Institute of Agricultural Research \\ for Development (IRAD), Nkolbisson Regional Research Centre, BP 2067, Yaoundé, \\ Cameroon.
}

Corresponding author: Hervé D. B. Bisseleua; email: hbissel@gwdg.de

\begin{abstract}
This study was performed in an attempt to understand the mechanisms of land acquisition and access to resources and new technology by women and how these resources are managed by looking at the traditional cocoa forest garden (TFG) in southern Cameroon, under the prevailing liberalization of the cocoa marketing sector after the economic crisis and the current international cocoa price recovery. Cocoa as a cash crop is clearly integrated into the rural economies of women in southern Cameroon in different ways. However, their position to land is highly variable and contentious. Most of them gain rights to land through their relationships with men, as wives or kin. With rising land values, women's rights are changing and they have made use of anonymous land markets to create new access to land and new rights. Women described a complex situation in which a range of abiotic and biotic factors constrained their cocoabased livelihoods. They mentioned technical or biological, institutional and socioeconomic production constraints. Technical problems relate to pest damages and diseases and low soil fertility, whereas institutional and socio-economic problems relate to unequal access to productive assets, expensive inputs, lack of labour and unequal access to modern technology of production. Their relative high literacy offers the potential for the use of written media, radio and video in sensitization efforts. Strengthening women
\end{abstract}


property rights will reduce deforestation and contribute to the sustainable management of resources even under current social and ecological changes and can have a significant and positive effect on reducing hunger and poverty.

Keywords: women rights, productive assets, modern technology, equal access, inequality, resource management, cocoa, poverty reduction.

\section{Introduction}

Throughout the world, agrarian land tenure reform and contract farming to forest protection have contributed to exclude women from access to and control over a wide range of land, forest, tree resources and their products. The rights to use land, water, plants, animals and their products always differ between men and women in traditional societies, with lack of equity as a consequence (Guyer 1980; Rocheleau and Edmunds 1997). The emergence of feminism and concerns over gender inequality in sustainable development has geared today the mechanisms over the distribution and control of property (Klasen 2005). Women rights are lacking a sound basis and are under pressure from a variety of changes in land-use, family composition and household structure (Lastarria-Cornhiel 1995).

The rural economy of southern Cameroon is dominated by cocoa in smallholdings and the population is dominated by the Beti (Guyer 1980; Kazianga and Masters 2006). This society is patrilineal in which men hold most or all of the important political positions. Farming system is based on long fallow and slash-and-burn techniques in a forest environment using the short handled hoes (Duguma et al. 2001). Both sexes contribute to farming in different degrees and capacities. Women's work was culturally associated with production from the earth and production of children. Tasks involving handling the earth were closely associated with women. These include pottery, farm labour and puddling mud for house building. Men were associated with work involving metal and wood. They cleared forest for planting, felled trees, built fences against wild animals and contributed to the farming of maize and plantain.

However, cocoa cultivation became men's work due to its technical characteristics (planted in newly cleared forest fields) and the new materials benefits and wealth it's 
provide to the people (Sonwa et al. 2001). Cocoa farming also constituted a form of permanent occupation of the land because land ownership right was vested in men. Therefore, women traditional obligation to supply the labour force during harvest, processing, and transport was extended to cocoa without change in the definition of the division of labour. With the non and, in some areas, the poor commercialization of food supply and lack of ability of women to process and market the foodstuffs they produce, the cocoa economy put pressure on rural women in southern Cameroon to remain in subsistence production. The liberalization of the cocoa marketing sectors followed by the emergence of cocoa farmers associations such as the "Common Initiative Groups" (Groupements d'Initiative Commune, GIC), Union of GIC or farmer's federation have contributed very little in improving women rights access to resources. The few who bought or inherited land from husband or brothers are ignored when providing technical assistance, training or in decision-making processes.

In the current context of globalization and sustainable management of agricultural landscape for ecosystem services and to improve human wellbeing, there is a growing concern for improving women's influence over decision-making, for strengthening their voice in the process which creates the rules that governs resource access and control by involving both men's and women's organizations in traditional cocoa forest garden (TFGs) management and in the development of land use codes and policies.

The general objective of this paper is to strengthen the autonomy of women in TFGs management. Autonomy here includes an economic, political, physical and ideological dimension and could be summarized as the control over own life (Zweifel 1995).

In an attempt to understand the mechanisms of land acquisition by women in southern Cameroon and the impact of their management practices on the incidence of pest, diseases, yields and income in TFG, in the current context of changing economy we hypothesized that (i) women have unequal access to productive assets such as land and planting materials; (ii) women have unequal access to modern technology of farm management such as IPM; (iii) unequal access to productive assets and modern technology negatively affect women productivity and income. 


\section{Material and method}

\section{Study area and research approach}

This study was performed from August to December 2005 in the centre province of Cameroon. Five types of traditional forest gardens (TFG) in five agro-ecological zones in the Nyon and So'o (Ngomedzap), Lékié (Obala), Mbam and Inubou (Bakoa and Kedia) and Mbam and Kim (Talba), are present with cocoa grown as the main cash crop under different land-use management. The populations surveyed were the Ewondo and Bulu of the Beti subgroup in Ngomedzap located $150 \mathrm{~km}$ south of Yaoundé, the capital city; the Etong, another Beti subgroup, in Obala located $50 \mathrm{~km}$ north of Yaoundé; The Bafia in Bakoa and Kedia located 150 and $180 \mathrm{~km}$ respectively, northwest of Yaoundé and a cosmopolitan group made of migrants from various provinces of Cameroon and dominated by the Etong, the Manguissa, the Baboute and the Nanga in Talba at $180 \mathrm{~km}$ northeast of Yaoundé. These tribes migrated to the region in the search of greener pasture for agriculture and as labour force because of the high dynamic of agriculture and cocoa production under intensive land-use management.

Six Union of GICs (Common Initiative Group) and five federations of cocoa farmers were identified and selected for the study, regrouping 69 GICs with a total of 4189 cocoa farmers (Table 1). In each zone, the process started with a community meeting with the help of ASPA (Appui aux Strategies Paysannes et à la Professionnalisation de l'Agriculture) of the Ministry of agriculture and rural development (MINADER, Cameroon) to inform all cocoa farmers and the respective "Common Initiative group" (GIC) about the objectives of the study and to ask for their participation and action planning. During these meetings women cocoa farmers were identified and interviewed.

\section{Field methods}

The survey consisted of a total of 55 women cocoa farmers sampled and interviewed individually in the five zones, in a total of 6 unions around Ngomedzap, Obala, Kedia, Bakoa and Talba according the field methods used in Chapter 2. 


\section{Results}

\section{Socio-economic background}

Seventy four percent of the overall women surveyed were widow, $11.1 \%$ were married while $5.6 \%$ of them were single and $9.3 \%$ divorced or separated with their husband. Mean age of women cocoa farmers was 56 years (SD: 11.53) with younger farmers recorded in the married women group and the oldest among the divorced ones. About 33 $\%$ of women had some primary education while $24 \%$ has completed primary education and $9 \%$ have attended secondary school. Higher level of education was observed among the married and the single women groups who have completed primary. Widows and divorced women were the least educated and had less than primary education or some primary education. However $63 \%$ of women can read and write. The number of children per woman varies significantly between groups with widow and married women groups recording an average of 6 to 7 children while women in the single and divorced groups recorded an average of 3 children.

In southern Cameroon, $7.41 \%$ of women have acquired land by their purchasing power. Most of the single women who are employed or are on pension were recorded in this group while $20.37 \%$ acquired land from their family or family members (Brothers, Aunts or Uncle). However, $74.07 \%$ of women got land from their husband or through marriages (Figure 1). There was a significant difference $(p=0.020)$ in the cocoa farming experience between groups (mean: 19.65 years) with younger experience (11 years) recorded within married women and older within the single (28 yrs) (Table 2). Women grow cocoa in smallholdings with farm sizes averaging 2.13 hectares/women in the married groups and 1.42 in the single groups. Number of farm did not differ significantly between groups (Table 1).

To meet the household requirements, women also produced crops such as maize $(90.7 \%$ total respondents), plantain/banana $(88.9 \%)$, cassava $(87.0 \%)$, groundnut $(87.0 \%)$, cocoyam $(85.2 \%)$, yam $(46.1 \%)$, melon seed $(24.1 \%)$ and beans $(20.4 \%)$ respectively in home gardens. Crops such as oil palm ( $9.3 \%$ of total respondents), tomato $(7.4 \%)$ and pineapple $(5.6 \%)$ requiring more tasks are less produced by women. 


\section{Farm characteristics}

Planting materials in women plantations were dominated by the "German cocoa" cultivars $(77.8 \%$ of total respondents), followed by the local breed materials $(44.4 \%)$, hybrids (35.2\%) and "Tout venant" or mixed materials $(3.7 \%)$. The highest proportion of the "German cocoa" cultivars was recorded within widow group (54.49\% of total respondents) while the highest proportion of local material used as cultivars was recorded within the married group ( $70.94 \%$ of total respondents) and the divorced group (50\% of the total respondents). The single group used in equal proportions both the "German" and hybrids cultivars $(40.11 \%$ of total respondents). There was no significant difference between groups on the type of shading trees used in cocoa plantations. About $94 \%$ of women surveyed reported to associate forest trees and fruit tree species as shade. However, $5.6 \%$ of respondents have only fruit trees as shade and $1.9 \%$ had no tree as shade. When looking at the location of cocoa farms, there was no significance difference in location of cocoa farms between groups, with $88 \%$ of cocoa farms located near the village, $9 \%$ near the forest and $3.1 \%$ in the forest. Average number of cocoa tree per farm varies from 1660 trees/farm in divorced groups to 2250 trees/farm in married ones with mean age of trees per TFG ranging from 19.17 years in married group to 49.90 years in the widow group. The number of cocoa tree was related to farm size $\left(\mathrm{F}=12.23, \mathrm{r}^{2}=0.19\right.$, $\mathrm{p}<0.002$ ) while the age of cocoa trees was not related to farming experience or the age of women. Results from women's perception showed that agronomic practices such as pruning, coppicing and shade management are practiced after harvest or just before flowering in all groups. More than $74 \%$ of women in TFG prune their cocoa trees or manage shade but coppicing is just practiced by $25.9 \%$ of women. Only forest trees with economy importance are selected as shade. Family as source of manpower was reported by most women with $71.4 \%$ of women in the married group and $65.3 \%$ in the widow group relying on their family as source of labour. However, about $67 \%$ of women in the single group, $29 \%$ in the married and widow group respectively, and $50 \%$ of women in the divorced group rely on casual workers as labour. Only $12.5 \%$ of women in the divorced group and $6.5 \%$ in the widow group employed permanent remunerated labour. No women in the married and single groups reported employing permanent workers. 


\section{Constraints of production}

Women's knowledge and ranked major constraints in production revealing in order pests, dieback, diseases, soil fertility, market accessibility and varieties grown as the most important. Among pests women recognized in other of importance mirids, stem borers, pod borers, defoliators, ants and termites. They also identified pods, chupons and young cocoa trees as the most preferred feeding materials of mirids. Pods loss to mirids and black pod diseases was significantly $(\mathrm{P}<0.001)$ different between groups (Fig. 2). Hybrids cultivar (38.9\% of the total respondents) was recognized by women as the most susceptible cultivar to mirids and local materials (only $11.1 \%$ ) the least. Other pests reported were small mammals (94\% of total respondents), thieves (41\% of total respondents), large mammals (26\% of total respondents) and birds (6\% total respondents). Black pod caused by $P$. megakarya was identified by women as predominant disease of pods with ants $(22.2 \%$ of total women $)$, mirids $(18.5 \%)$ and millipedes $(13.0 \%)$ perceived as main disseminating agents.

\section{Women's' practices in pest and disease control}

Farms were generally treated with almost all women applying pesticides. Treatments were with fungicides (79.6\% of women), insecticides ( $46.3 \%$ of women) or insecticides mixed with fungicides $(20.4 \%)$. When asked about the contact with cocoa extension agents, the majority $(83.3 \%)$ of women never had contact with extension agents. About $91 \%$ of women across the zone have never heard nor have any knowledge about IPM. Ants tending activity was never reported by any of the women interviewed. Women have no knowledge of indigenous methods (the use of botanicals or plants extracts) of pests and diseases control and have never used any of them in their farm and as a consequence have no opinion about which method is the best.

\section{Cost of inputs, yield assessment and alternative source of income}

Women invested on average 60.34 USD (SD: 16.56 USD) (1 USD = 500 FCFA) on pesticides and 67.97 USD (SD: 16.48 USD) on labour. Women in the single group recorded significantly $(\mathrm{P}=0.002)$ the lowest cost of labour and pesticides (Figure 3). Yield per hectare vary significantly $(\mathrm{P}=0.002)$ between each group with an average yield per hectare of $369.85 \mathrm{~kg} / \mathrm{ha}$ (SD: 55.88). The highest yield per hectare was recorded within 
the widow group (521.70 kg/ha) (Fig. 4). Only women in the married group and those in the widow group sold a significant quantity of exotic fruits (Figure 4). Results from figure 5 show that the average income per woman from the selling of cocoa and exotic fruits was 418.47 USD (SD: 63.60 USD) with women in the single group recording significantly $(\mathrm{P}=0.002)$ the lowest income. However, $7.5 \%$ of women as widow were on pension. Other source of income were animal breeding and petit trading accounting for $1.9 \%$ of the total respondents respectively.

\section{Discussion}

This study was performed in an attempt to understand the mechanisms of land acquisition and access to resources and new technology by women and how these resources are managed by looking at the traditional cocoa forest garden (TFG) in southern Cameroon, under the prevailing liberalization of the cocoa marketing sector after the economic crisis and the current international cocoa price recovery.

Our results show that women involved in cocoa farming in southern Cameroon are divided into four groups namely the married women, the single, the widow and the divorced or separated ones with their husband. They are all smallholders growing cocoa on small plots of land. Land acquisition by women is of three types, by purchasing or through their relationship with men, as wives or kin (their father, brothers or Uncle). However, most women acquired land by helping their husbands or as an inheritance after the death of their husband. Cocoa is their main source of income, specifically among the married and widow groups. However, they also grow food crops for subsistence. Since women are equally productive cocoa farmers, the demand for cocoa has created more employment opportunities for women in southern Cameroon and men are beginning to give women land rights and some are willing their land to their wives, who work as their farming partners. During the establishment of a cocoa farm, women do much of the planting, weeding and ploughing with the short handled hoes. Cocoa has become one of the principal income-

generating assets available to rural people with low incomes, and a substantial number of women have invested part of their savings in bearing trees. This is exemplified by the fact that wealthier women have responded to tenure insecurity by purchasing land that is clearly 
in their name, which they can use and transfer as they wish. The proportion of these female farm-owning entrepreneurs (Mikell 1984) is on the rise in southern Cameroon. Although the primary task of a wife is to cultivate food crops that shade the cocoa seedlings and which are used to meet the daily household requirement. Women farmers also believed that the best way to insure adequate annual income in later life is to obtain a cocoa farm. Therefore, they help to increase the holdings of established cocoa farmers such as their father, their brothers or uncle. As young women they usually help family members and were entitled to a portion of the cocoa income and later used this cash to buy land or pay for laborers. Women also received cocoa farm, or land for cocoa farming, by working for their husbands. However, the majority of women in southern Cameroon were still waiting to receive land or a small portion of an existing cocoa farm from their husband. Although more than $60 \%$ of women could read and write, in general most of them who acquired a cocoa farm did so late in life (higher age within the widow and divorced groups) and these holdings are usually small with old and less productive trees (German cocoa) that need rehabilitation. Older women do not have the strength or resources to farm on their own and rely on limited assistance from their husbands, children or paid laborers.

In most societies of southern Cameroon, there is a difference among women in interests, rights and responsibilities. Age, and in polygamous households, order of marriage are important factors in determining women's rights and responsibilities under customary resource tenure law. Older widow for example, have significantly greater decision-making power over planting, care and disposal of trees and timber tree species than do younger widows. Though, this rule do not apply to single women whom with their independence and purchasing power can own land, hence their longer experience in cocoa farming. Because in southern Cameroon planting a tree on a plot gives the right of ownership and usufruct over that plot, cultivating cocoa provides women with economic security and a more secure way to gain rights to land. Moreover, studies have shown that women spend most of their additional income on their children (IFPRI 2002). Increasing women income will secure households by increasing food security and improving children nutrition, health and has positive impact on resource management, ecosystem services and good as well as securing forthcoming generations with positive impact on growth and poverty (Klasen 2006). Nevertheless, when comparing women in southern Cameroon with others in other 
part of the world such as in rural area of Asia (Kritz and Gurak 1989), women's economic independence in southern Cameroon derives from the traditional practices of wives receiving land from their husbands' to grow groundnut, cassava and other subsistence crops for feeding the family. The surplus is sold and the income kept, therefore providing cash for small trading and additional income for family expenditures or for personal use, giving them a certain degree of independence, access to resources and autonomy of movement and decision-making.

The management practices in women traditional cocoa forest gardens are influenced by socio-economic, technical or biological and environmental parameters. Groups were classified based on women socio-economic characteristics and farms abiotic and biotic characteristics. After the economic and cocoa crisis (Coulibaly et al. 2002) cocoa farmers, including women have become independent decision makers in agriculture. Most farmers or their organization's now make their own decisions about what to plant, what cultivars or varieties to use. In this way, cocoa farmers in Cameroon are similar to smallholder farmers in other developing countries. Farmers have developed methods in plant breeding and protection based on observational skills. Local cultivars ("Tout venant") were developed and are more satisfactory than hybrids provided by the extensions before the crisis. However, the "German cocoa" that most farmers are not willing to plant in spite of its resistance to mirids attack and black pod disease; and because of its low productivity (only one production per cropping season compare to two with hybrids and others cultivars locally developed) was the most common cultivars reported by women, suggesting that women received cocoa farms with old and less productive trees. On the other hand previous studies in TFG management reported that cocoa plantations near the village recorded a significant lower timber tree species richness and density and higher number of pods loss to mirids and P. megakarya (Chapter 4). Our findings suggest that men lay claim to high yielding cultivars, timber tree species, commercial cash crops or fertile soil. Flexibility and independent access to resources regardless of sex, age, class, ethnicity, context or other differences are to be encouraged to avoid women losing access to vital resources. As suggested by Rocheleau and Edmunds (1997) flexible strategies are opened to negotiation, based on the social and political relations among users. Ignoring negotiation in social processes allows the more powerful groups to cease resources that benefit them. Recognition of the importance of negotiation may provide women with 
better opportunities to defend existing rights to resources, and to expand those rights as social and ecological conditions change as it is the case in the cocoa sector. Moreover, introducing high yielding or new varieties as requested by many cocoa farmers, specifically women, will raise the already-high deforestation rates if property rights are not strengthened (Kazianga and Masters 2006).

Women were able to identify biological and non-biological constraints to production. Biological constraints includes pests such as mirids, podborers, stemborers, mammals (small and large) and thieves; and disease such as the black pod disease caused by Phytophthora megakarya. Dieback was reported by women as the second constraint in production suggesting an alteration of habitat of natural enemies of the incriminated pathogen. Continuous removal of trees from TFG could result in a significant biodiversity loss and pest and diseases outbreaks. Although there is no study documenting the role of biodiversity in preventing disease outbreaks, Perfecto and Castiñeira (1998) suggested that diverse insect communities can offer better protection against pest outbreaks than communities dominated by fewer species. Women have in-depth knowledge of some common pests and diseases. They were also able to identify their mode of dissemination and to explain and appreciate the direct benefit of adopting certain practices. It is observed that women are very well knowledgeable on phenomenon in nature they can easily observe while less obvious ones may escape their attention (Bentley, 1992; Van Huis and Meerman, 1997). The institutional constraints range from lack of knowledge of IPM (Integrated Pest Management) to lack of extension services, loss of soil fertility, and poor market access. Poor institutional support to women was also reported by Carney (1992) in Gambia in the case of rice and Rocheleau (1991) in community reforestation projects. As a result, there is a growing concern for improving women's influence over decision-making, for strengthening their voice in the process which creates the rules that governs resource access and control by involving both men's and women's organizations in traditional cocoa forest management (TFG) and in the development of land use codes and policies. In order to improve women's access to product benefits, policy makers are to encourage complementarity between men and women in the processing and marketing of tree products from TFG. Women or their organization should have equal access to technical and administrative information which affect TFG management. 
In general, women found it difficult to mobilize labour; however they rely on family labour as the main source of labour for production. Family labour was the only type of labour employed by married women while remunerated labour was mostly observed in other groups suggesting that married women may easily mobilize unpaid labour usually from their husbands', subordinate family members from their own or from their husband's. Husbands' rights to the labour of their wives and fathers to that of their daughters meant that women and men are likely to help each other. Services of husbands' to the wives tree crops is an extension of husbands' conjugal obligations to contribute to household consumption and assist the wife in farming activities. This observation is contrary to that reported by Berry (1988) and is exemplified by the high proportion of remunerated labour among the single and divorced women. Restrictions on single and divorced women ability to mobilize labour for tree crop cultivation is partly the result of custom where the division of agricultural and domestic labour is embedded in conjugal and domestic relations and merge with conjugal rights and responsibilities.

However, most plantations owned by women were located near the village. According to Brown (1970), women's work in traditional societies is related to the exigencies of child care. Cyclic, interruptible, non-dangerous tasks with less extensive excursions are more suitable to women when the exigencies of child care are taken into account. Therefore, women are allocated plantations and tasks in the production sequences beginning with low risk tasks closer to home, thus saving on distance and time, which can be devoted to other household tasks (Sonwa et al. 2001). Also, because most women acquired land when very old, they prefer plantations that will require less extensive excursions. In addition to cocoa, exotic fruits provide an additional average income to women advocating the development of mechanisms of supporting women's gathering rights as a legitimate land use within both customary and formal tenure regimes. With government support, women's progress towards greater empowerment can have a significant and positive effect on reducing hunger and poverty (Klasen 2006). However, women must continue to fight for more rights and greater control of their destinies. 


\section{Conclusion}

Cocoa as a cash crop is clearly integrated into the rural economies of women in southern Cameroon in different ways. However, their position to land is highly variable and contentious. Most of them gain rights to land through their relationships with men, as wives or kin. With rising land values, government and donor interventions, and the prevailing liberalization of the cocoa marketing sector and the current international cocoa price recovery, women's rights are changing. In response to that, women have made use of anonymous land markets to create new access to land and in some cases, new rights. Women described a complex situation in which a range of abiotic and biotic factors constrained their cocoa-based livelihoods. They mentioned technical or biological, institutional and socio-economic production constraints. Technical problems relate to pest damages and diseases and low soil fertility, whereas institutional and socio-economic problems relate to unequal access to productive assets such as planting materials, expensive inputs, lack of labour and lack of technical assistance. Women are knowledgeable about their problems and can be principal actors in the process of technology development through an educational system that combines aspects of Western technical knowledge with local knowledge. Their relative high literacy offers the potential for the use of written media, radio and video in sensitization efforts. Strengthening women property rights will reduce deforestation and contribute to the sustainable management of resources even under current social and ecological changes and can have a significant and positive effect on reducing hunger and poverty. Research has paid little attention to women's demands as have the extension services at it time to wok together with men, women and their organizations in improving indigenous methods of plant breeding and protection as well as helping them to understand mechanisms regulating social and biological constraints in the management of traditional cocoa forest gardens. Local knowledge is often region specific and recommendations must be adapted to each producing area. Issues such as equal rights to own and inherit land as men and education on women rights; Legal support to women's to enforce their legitimate claims to land; equal access to credit and other inputs and equal access to technical and administrative information in TFG management are to be considered for sustainability of cocoa production in Cameroon. 


\section{Acknowledgments}

We thank the University of Goettingen (IPAG "International PhD Programme in Agricultural Sciences in Goettingen" and Entomology section) for financial support. Enumerators and key informants from farmers' organizations surveyed.

\section{References}

Bentley, J.W. (1992) The epistemology of plant protection: Honduras campesinos knowledge of pests and natural enemies. In: Gibson, R. W. Gibson., Sweetmore, A. (Eds.), Proc. of a Semi. On Crop Protec. for Resource-Poor Farmers, National Resources Institute (NRI), Chatham, pp. $107-118$.

Berry, S. (1988) Property rights and rural resource management: The case of tree crops in West Africa. Cahiers Sciences Humaines. 24 (1), 3 - 16.

Brown, J. K. (1970) A note on the division of labor by sex. American Anthropologist. 72, $1073-1078$.

Carney, J. (1992) Peasant women and economic transformation in the Gambia. Development and Change. 23, 67-90.

Coulibaly, O., Mbila, D., Sonwa, DJ., Adesina, A., Bakala, J. (2002) Responding to economic crisis in sub-saharan Africa: New farmer-developed pest management strategies in cocoa-based plantations in Southern Cameroon. Int. Pest Manage. Rev. 7, $165-172$.

Degrande, A. and Duguma, B. (2000) Adoption potential of rotational hedgerow intercropping in the humid lowlands of Cameroon. Agricultural Research and Extension Network. 103, 8pp. 
Duguma, B., Gockowski, J. and Bakala, J. (2001) Smallholder cacao (Theobroma cacao Linn.) cultivation in agroforestry systems of West and Central Africa: Challenges and opportunities. Agroforestry Syst.. 51, $177-188$.

Gray, L. and Kevane, M. (1999) Diminished access, diverted exclusion: Women and land tenure in sub-Sahara Africa. African Studies Review. 42 (2), 15 - 39.

Guyer, J.I. (1980) Food, Cocoa, and the division of Labour by Sex in two West African Societies. Society for the Comparative Study of Society and History, 355 - 373

IFPRI. (2002) Empowering women and fighting poverty: Cocoa and land rights in West Africa. Annual report. 8pp.

Kazianga, H. and Masters, W. (2006) Property rights, production technology, and deforestation: cocoa in Cameroon. Agric. Econ. 35, 19 - 26.

Klasen S. (2005) Economic growth and poverty reduction: Measurement and policy issues. OEDC Development Center Discussion paper Nº 246. Paris: OECD.

Klasen, S. (2006) Pro-poor growth and gender inequality. In: Bourdon, J. Frölich M., Grimm, M., Klasen, J., Klonner, S., Klump, R., Lay, J., Micaelowa, K., Cabrera, M.A. C., Thiele, R. Wiebelt M. (Eds), Pro-poor growth: Policy and Evidence. Dunker \& Humblot, Berlin, pp $151-179$.

Kritz, M.M. and Gurak, D. T. (1989) Women's status, education and family formation in Sub-Saharan Africa. Int. Fam. Plan. Perspec. 15 (3), 100105.

Lastarria-Cornhiel, S. (1995) Impact of privatization on gender and property rights in Africa. Paper prepared for the Gender and Property Rights International E-mail Conference, International Food Policy Research Institute, Washington DC, MayDecember. 
Mikell, G. (1984) Filiation, Economic Crisis, and the Status of women in rural Ghana. Canadian J. of Afr. Stud. 18 (1), 195 - 218.

Perfecto, I., Castiñeira, A., (1998) Deployment of the predaceous ants and their conservation in agroecosystems. In: Barbosa, P. (Eds.), Conservation biological control. Academic Press, New York, pp. 269-289.

Rocheleau, D. (1991) Gender, ecology and the science of survival: Stories and lessons from Kenya. Agric. and Human Values 8, 156 - 165.

Rocheleau, D. and Edmunds, D. (1997) Women, men and trees: Gender, Power and Property in Forest and Agrarian Landscapes. World Development. 25 (8), 1351 - 1371.

Sonwa, D.J.; Weise, S. F. Tchatat, M.; Nkongmeneck, B.A.; Adesina, A.A.; Ndoye, O. and Gockwoski, J. (2001) The role of cocoa agroforests in rural and community forestry in southern Cameroon. RDFN Paper. 25, 1- 10.

Stucki, B. (1992) The long voyage home: return migration among aging cocoa farmers of Ghana. Journal of Cross-Cultural Gerontology. 7, 363 - 378.

Van Huis, A., Meerman, F. (1997) Can we make IPM work for resource-poor farmers in sub-Saharan Africa? Int. J. of Pest Manage. 43, 313 - 320.

Zweifel, H. (1995) Modern biotechnology in agriculture: Impact on women in the south. Biotechnology and Development Monitor. 23, 10 - 13. 


\section{List of Figures}

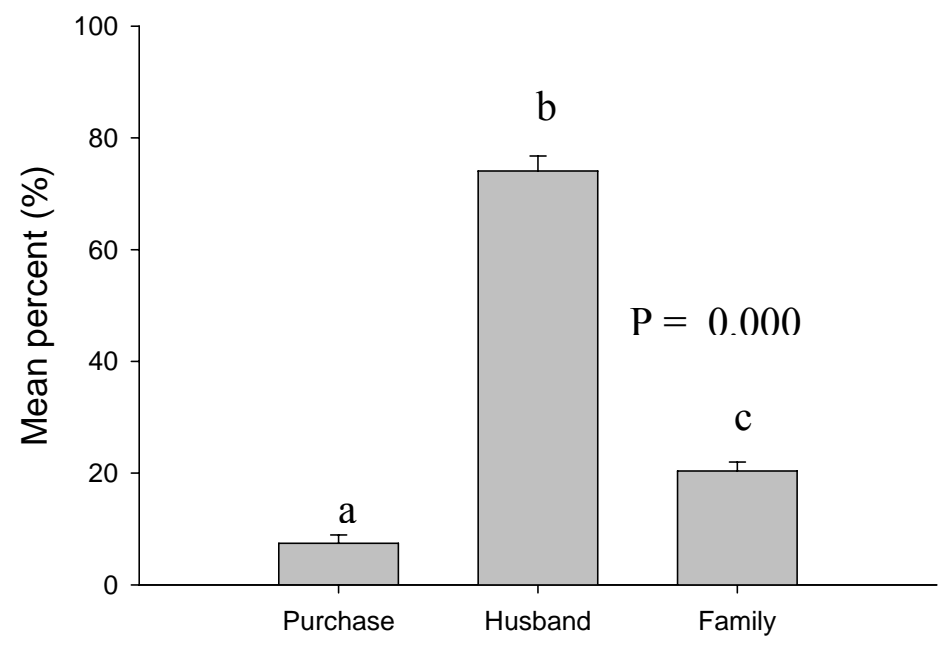

Form of land acquisition

Figure 1. Different form of land acquisition as reported by women cocoa farmers

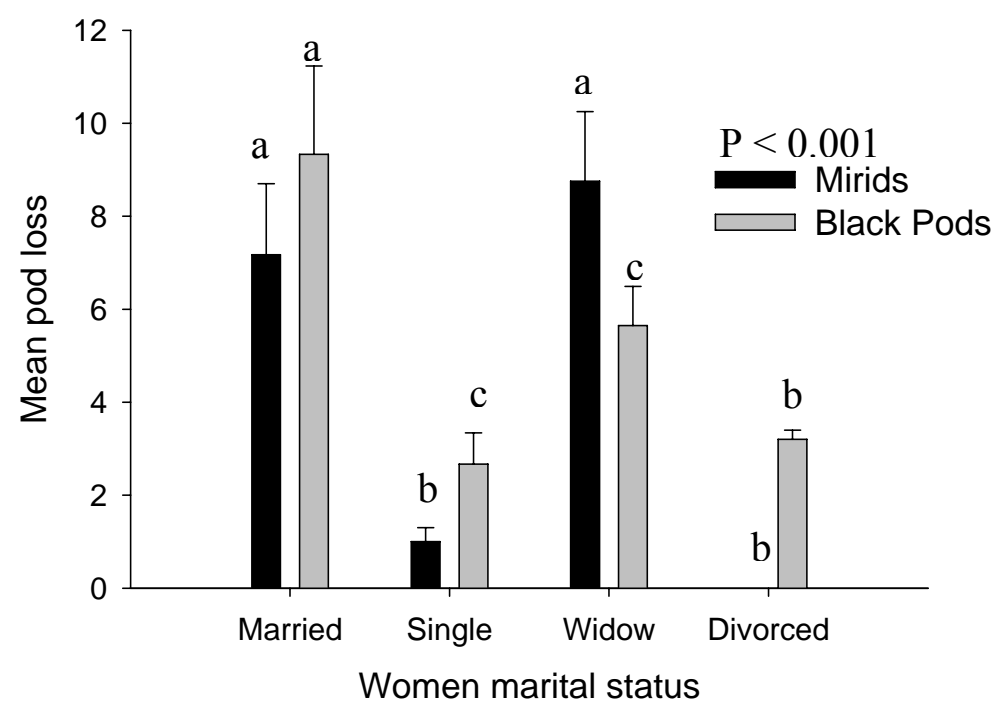

Figure 2. Pods loss to mirids and black pod disease as perceived by different groups of women in TFG 


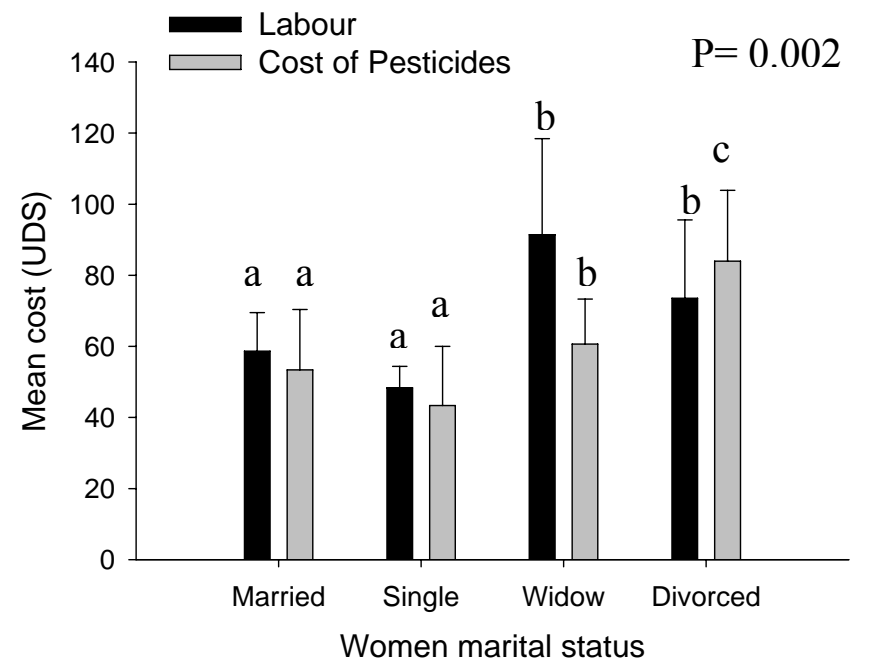

Figure 3. Cost of labour and pesticides and perceived by various groups of women $(1 \mathrm{USD}=500 \mathrm{CFA})$
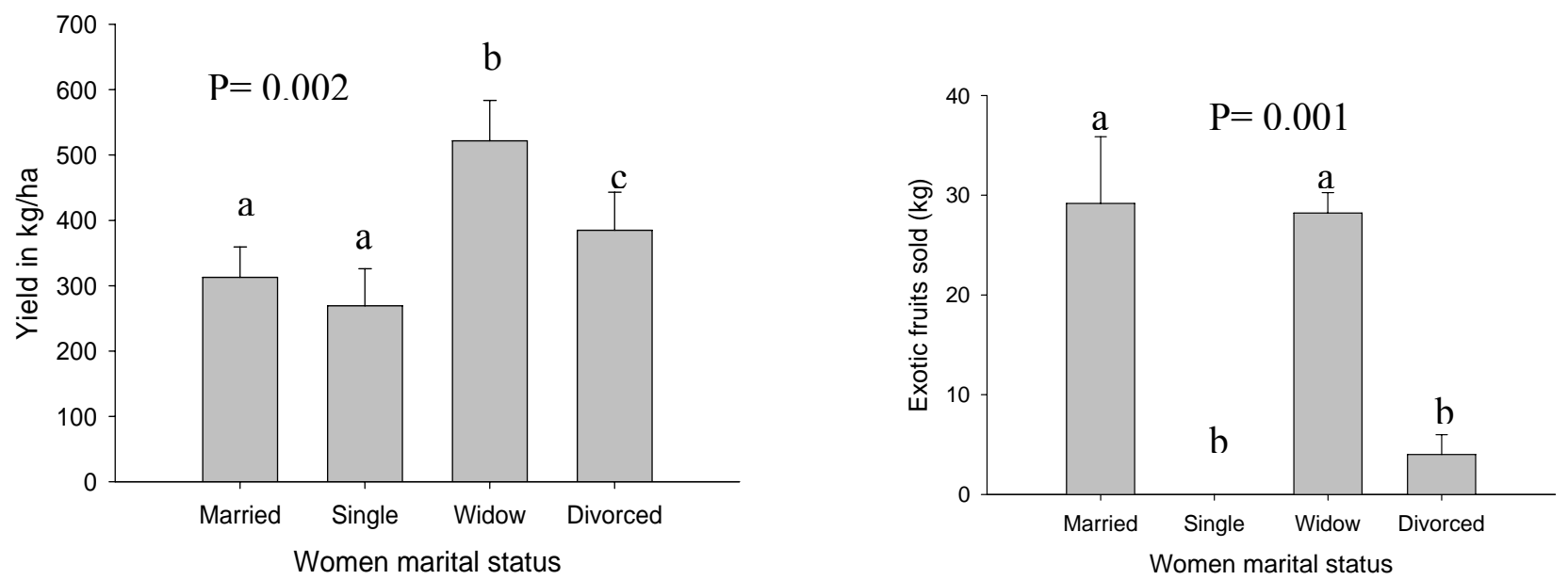

Figure 4. Women record of cocoa yield (kg/ha) and exotic fruits sold per year 


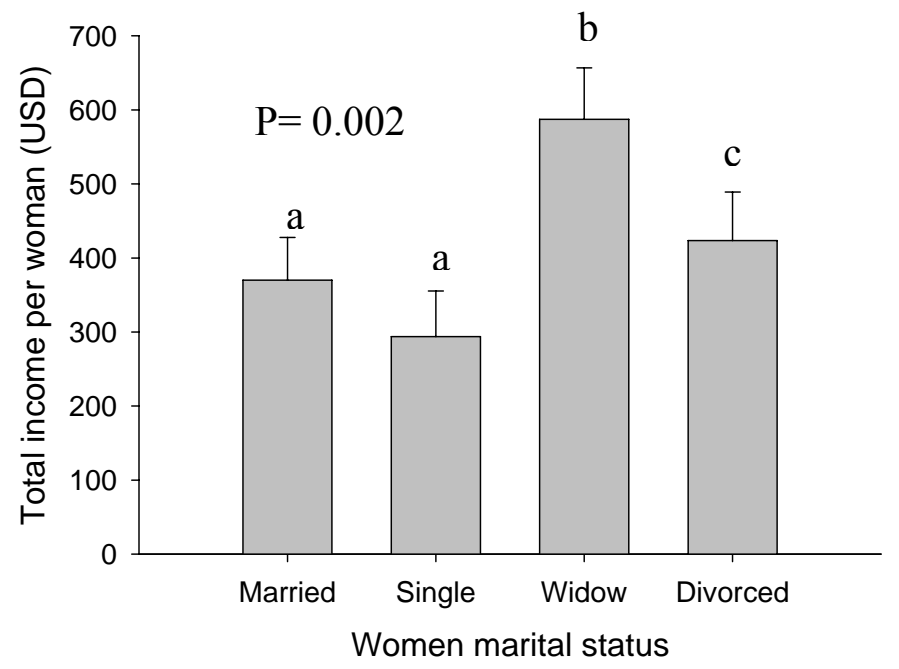

Figure 5. Yearly income from women derived from the selling of cocoa beans and exotic fruits $(1 \mathrm{USD}=500 \mathrm{CFA} ; 1 \mathrm{~kg}$ of cocoa $=543.04 \mathrm{CFA}$ and $1 \mathrm{~kg}$ of exotic fruit $=500$ CFA). 


\section{List of Tables}

Table 1. Cocoa farmer's organizations selected for the study

\begin{tabular}{|c|c|c|c|}
\hline Locality & Federation & \multicolumn{2}{|c|}{ Union } \\
\hline \multirow[t]{2}{*}{ Ngomedzap } & FUPROCAN & UGISET & UGICAABO \\
\hline & & 5 GIC - 213 Farmers & 5 GIC- 120 Farmers \\
\hline \multirow[t]{2}{*}{ Kedia } & FUPROCAM & UGIKAKED & \\
\hline & & 4 GIC - 114 Farmers & \\
\hline \multirow[t]{2}{*}{ Bakoa } & FUPROCAM & UGICABO & \\
\hline & & 17 GIC - 950 Farmers & \\
\hline \multirow[t]{2}{*}{ Talba } & FUPROCATS & UGICATS & \\
\hline & & 14 GIC - 1200 farmers & \\
\hline \multirow[t]{2}{*}{ Obala } & FUPROCALE & UGIPLACALE & \\
\hline & & $24 \mathrm{GIC}-1592$ farmers & \\
\hline
\end{tabular}

Table 2. Socio-economic background of the surveyed women cocoa farmers

\begin{tabular}{cccccc}
\hline & $\begin{array}{c}\text { Age } \\
\text { (years })\end{array}$ & $\begin{array}{c}\text { Number of } \\
\text { Children }\end{array}$ & $\begin{array}{c}\text { Farm size } \\
(\text { ha })\end{array}$ & $\begin{array}{c}\text { Farming } \\
\text { Experience }\end{array}$ & $\begin{array}{c}\text { Number of } \\
\text { Cocoa farm }\end{array}$ \\
\hline Married & 46.56 & 6.50 & 2.13 & $10.50 \mathrm{a}$ & 1.00 \\
Single & 53.67 & 3.33 & 1.42 & $28.33 \mathrm{c}$ & 1.33 \\
Widow & 56.35 & 5.90 & 1.67 & $20.45 \mathrm{~b}$ & 1.23 \\
Divorced & 61.80 & 2.60 & 1.60 & $19.00 \mathrm{~b}$ & 1.20 \\
\hline Mean \pm SE & $55.61 \pm 1.57$ & $5.52 \pm 0.53$ & $1.70 \pm 0.21$ & $19.65 \pm 1.78$ & $1.20 \pm 0.07$ \\
\hline
\end{tabular}

* Numbers within column followed by the same letters are not significantly different 


\title{
Impact of Cocoa farmers' management practices on the incidence of pests, diseases and yield in traditional cocoa forest gardens in southern Cameroon
}

\author{
${ }^{1,2}$ Hervé D. B. Bisseleua and ${ }^{1}$ Stefan Vidal \\ ${ }^{1}$ Georg-August-University Goettingen, Department of Crop Sciences, Entomological \\ Section, Grisebachstr. 6, 37077 Goettingen, Germany; ${ }^{2}$ Institute of Agricultural Research \\ for Development (IRAD), Nkolbisson Regional Research Centre, BP 2067, Yaoundé, \\ Cameroon.
}

Corresponding author: Hervé D. B. Bisseleua; email: hbissel@gwdg.de

\begin{abstract}
A study was undertaken in the humid rainforest area of southern Cameroon to assess farmer's socio-economic background and farming practices with focus on gaining an understanding of farmer's awareness of the ecological and economic changes as a result of liberalization of the cocoa sector. Surveys of 400 cocoa farmers on their socio-economic background, indigenous knowledge of cocoa agroforest management practices and biological diversity was reviewed in relation to pest, disease and yield to design participatory activities for sustainable management of cocoa forest gardens farmers within four cocoa growing regions under a gradient of intensification. Cocoa farming in southern Cameroon is dominated by smallholders with family labour as the main source of labour. Family children made a significant contribution to this labour pool. However, an increasing proportion of cocoa farmers' contract casual and permanent labour to meet additional labour demands. We observed an increased knowledge or use of indigenous pest and disease control methods such as botanicals. A positive and significant correlation was recorded between millipedes and black pod diseases. Significant litter cover was observed to improve yield. Pods loss to mirids depended primary on land-use intensity and only secondarily on the varieties grown. Farmers are
\end{abstract}


still reliant on pesticides use for pests and diseases control and their current control practices suggest that a large proportion of the farmers' seem to be making inappropriate management decisions against mirids or black pods. We believe that providing farmers' with new and indigenous/local knowledge would enable themselves to develop appropriate pest and diseases management strategies and make decisions as to which strategies to accept and demand. Including farmers in the process of technologies development is less likely to end up being rejected. Farmer's positive attributes should be acknowledged by expanding the knowledge and range of options available to them.

Keywords: cocoa farmers, smallholder, management strategies, biological constraints, participation, technologies development.

\section{Introduction}

The Sub-Saharan Africa is currently the world's leading cocoa producing regions accounting for about $70 \%$ of the world's cocoa supply with Côte d'Ivoire, Ghana, Nigeria and Cameroon as the four largest cocoa producers (ICCO, 1997).

In Cameroon, about $80 \%$ of the production is in three provinces namely the South West (35\%), the Centre (28\%) and the South (16\%). In 1999, cocoa provided about 6 percent of the government export revenues, and was the third largest revenue source after oil and wood (Anon., 2002). Generally, yields are low, averaging around $300 \mathrm{~kg}$ per hectare (Duguma et al., 2001). Until the early 1990s, cocoa farmers were receiving subsidies from the Cameroon government in the form of pesticides (fungicides and insecticides). The cost for the service was recovered through a state-controlled cocoa marketing system (National Produce Marketing Board (NPMB)). Following the fall in price and liberalization of the marketing sector, the government withdrew the service. In this chaotic cocoa markets, farmers were unable to pay for inputs or, if they were able, they had difficulty finding private suppliers. Consequently, the cocoa production suffered from neglect and, in some cases, was abandoned (Losch et al., 1990). When devaluation of the local currency (FCFA) occurred in 1994, the weak institutional development of privatized input market liberalized in 1992 inhibited a strong supply response. Cameroon cocoa, which once received a quality premium on world market, is now cut-rated because of this deterioration. However, in 1997, with the improvement in the world cocoa prices 
(producer prices varied between 1 US\$ and 1.4 US\$) farmers are again considering that cocoa farming can be a profitable activity.

Farmers reacted to these institutional changes by organizing themselves into associations known as the "Common Initiative Groups" (Groupements d'Initiative Commune, GIC). These associations have quickly become important in a few cocoa producing areas, particularly in the Centre. They are active at the level of a village, grouping in general between 40 and 100 producers. They have developed into more advanced structures in recent years such as "Union of GICs" (made up of four to ten GICs) and federation (five to eight Unions). These structures act as the farmers' marketing body, grouping cocoa produced by their members, for selling, through a tender or auctioning system in larger volumes, therefore achieving a better profit. Several of them are very well organized providing information on prices on the international market, buying inputs, providing technical assistance and training of members.

Cocoa in Cameroon is a crop of smallholders and provides about 60 to $80 \%$ of their income (Nyasse, 2002). Of recent, they have received less support and partly due to the lack of experience and/or expertise of the national extension services. Nevertheless, smallholders have organized themselves into Common Initiative Groups (GIC) and farmer organizations to improve cocoa management and production based on indigenous knowledge. However, their knowledge on management practices is often over-looked by researchers and extension services and recommendations have not been widely adopted by farmers, who do not find them relevant to their socio-economic considerations and not appropriate or not compatible with their prevailing production systems.

The small-scale cocoa farmers are generally resource-poor and risk-averse and their primary strategy is towards food security for their family. They do not tolerate pest infestations or diseases and have developed several strategies to solve these problems (Sonwa et al. 2002). For example, in response to the high price of inputs and low price of cocoa, some farmers modify the input recommendations, while other decided not to apply any inputs at all. This involves mixing of insecticides or fungicides with plant extracts. The farmers believe that this mixing increases the effectiveness of the chemicals and improve yield.

In Chapter 2, the cocoa farmers described a complex situation in which a range of abiotic and biotic factors constrained their cocoa-based livelihoods. They mentioned biological, 
institutional and socio-economic production constraints. Biological problems relate to pest damages and diseases most of which have received extensive research attention in Cameroon and low soil fertility which have been neglected. The institutional and socioeconomic problems relate to low price of cocoa, expensive inputs, lack of technical assistance, labour shortages and high cost of labour due to youth migration to the cities as a consequence of the lack of facilities like electricity. It was observed that these two categories of causes are closely inter-related with an impact on productivity. Therefore, it is important to understand the impact of farmers' management practices on the incidence of pest, diseases and yields in the current context of liberalization. Developing cost effective and environmentally sustainable integrated pest and disease management is a strategy likely to promote traditional cocoa forest gardens.

We examine farmers' socio-economic background and farming practices with focus on gaining an understanding farmers' awareness of the ecological and economic changes brought about as a result of liberalization of the cocoa sector. Specifically we attempted to understand the relationship between cocoa forest gardens, farmer indigenous knowledge of management and biological diversity in relation to pest and diseases and their livelihoods to draw conclusions for participatory activities for sustainable management of traditional cocoa forest gardens.

\section{Material and method}

\section{Study area and research approach}

The study area and research approach used are summarized in chapter 2.

\section{Field methods}

The survey consisted of a total of 400 cocoa farmers sampled and interviewed as summarized in Chapter 2. The survey data were encoded, entered into SPSS sheets and verified prior to analysis. Systat 11 and SPSS for windows (SPSS Inc. 2004) were used in the analysis. Frequencies in all type of response were analyzed and the influence of quantitative characteristics on qualitative ones was studied using multiple linear regressions (Systat 11 and SPSS). 


\section{Results}

\section{Farmer's social characteristics}

The farmer's social characteristics are summarized in Chapter 2. However, the results of our study show that the average number of children per household is significantly different $(p=0.003)$ between systems with the highest number of children per household recorded in IM. Number of children per household was not significantly correlated with the level of education and responded positively to cocoa farming experience $(\mathrm{F}=59.43$, $\mathrm{r}=0.36, \mathrm{p}=0.000)$ and farm size $(\mathrm{F}=42.45, \mathrm{r}=0.31, \mathrm{p}=0.000)$ (Figure 1).

\section{Biological and institutional constraints and incidence on mirids and black pod disease}

Our results showed that the number of pods per tree responded positively to the hybrids cultivars $(\mathrm{F}=19.48, \mathrm{r}=0.23, \mathrm{p}=0.000)$ and the litter cover $(\mathrm{F}=23.41, \mathrm{r}=0.25, \mathrm{p}=0.000)$. Pod loss to mirids decreased significantly $(\mathrm{F}=27.39, \mathrm{r}=0.25, \mathrm{p}<0.001)$ with increasing tree species richness and density (Figure 2). Pod loss to black pods was not related to tree species richness and density. Tree species richness responded negatively to farm size and positively $(\mathrm{F}=14.74, \mathrm{r}=0.20, \mathrm{p}<0.001)$ to the number of cocoa farms. When analyzing the association of forest trees species with cocoa, a positive association was observed between the number of pod loss to mirids and forest tree species such as Cola nitida $(\mathrm{F}=34.14, \mathrm{r}=0.28, \mathrm{p}=0.000)$, and Adansonia digitata $(\mathrm{F}=30.40, \mathrm{r}=0.27, \mathrm{p}=0.000)$. Rcinodendron heudelotii (local name:Djansang) $(\mathrm{F}=10.42, \mathrm{r}=0.16, \mathrm{p}=0.0014)$ associated with cocoa and the hybrids cultivars $(\mathrm{F}=6.83, \mathrm{r}=0.13, \mathrm{p}=0.009)$ responded positively to pods loss to black pod diseases.

The use of indigenous methods of pest and disease control increase significantly $(\mathrm{F}=4.18$, $\mathrm{r}=0.10, \mathrm{p}=0.04)$ with education level and marital status $(\mathrm{F}=5.64, \mathrm{r}=0.12, \mathrm{p}=0.02)$ from married to polygamous. No relationship was found between the knowledge and/or use of indigenous methods, the age of farmers, farming experience and the number of cocoa farms.

Our study shows a significant increase in the perception by farmers of millipedes as disseminating agents of black pod disease with age $(\mathrm{F}=5.56, \mathrm{r}=0.12, \mathrm{p}=0.04)$ and farming experience $(\mathrm{F}=9.38, \mathrm{r}=0.15, \mathrm{p}=0.002)$. However, younger farmers believed mirids 
$(\mathrm{F}=9.13, \mathrm{r}=0.15, \mathrm{p}=0.002)$ and wind $(\mathrm{F}=4.16, \mathrm{r}=0.10, \mathrm{p}=0.04)$ to be important vectors of black pods.

Increasing knowledge of IPM contributed in reducing significantly pod loss to mirids $(\mathrm{F}=19.17, \mathrm{r}=0.21, \mathrm{p}=0.000)$ and to black pod disease $(\mathrm{F}=7.26, \mathrm{r}=0.13, \mathrm{p}=0.007)$. On the other hand, we observed an increase in pod loss to mirids with the hybrid cultivars $(\mathrm{F}=$ 12.21, $\mathrm{r}=0.17, \mathrm{p}=0.005)$, location of the farms near the village $(\mathrm{F}=3.60, \mathrm{r}=0.10, \mathrm{p}=0.04)$ and with different type of commercial insecticide applied by farmers $(\mathrm{F}=12.94, \mathrm{r}=0.18$, $\mathrm{p}=0.0004)$ (Figure 3).

Organochlorine was reported as the most used class of insecticides sprayed by farmers and pyrethroids the least (Figure 4).

\section{Impact of socio-economic and institutional constraints on yield}

The number of cocoa bags harvested per cropping season increased significantly with the number of children per household $(\mathrm{F}=260.85, \mathrm{r}=0.63, \mathrm{p}=0.000)$ and with the farm size $(\mathrm{F}=22.07, \mathrm{r}=0.23, \mathrm{p}=0.000)$ ((Figure 5). Similar results were recorded between the cost of labour $(\mathrm{F}=169.33, \mathrm{r}=0.55, \mathrm{p}=0.000)$, contact with extension services $((\mathrm{F}=45.48, \mathrm{r}=0.32$, $\mathrm{p}=0.000$ ) (Figure 6) and the number of cocoa bags harvested per cropping season. The knowledge of IPM also contributed to increased significantly $(\mathrm{F}=6.94, \mathrm{r}=0.13, \mathrm{p}=0.008)$ the number of bag harvested per cocoa farmer. Another parameter that may have a significant impact on yield $(\mathrm{p}=0.008)$ is the use of crude extracts mixed with insecticides and fungicides.

Family as source of labour responded negatively $(\mathrm{F}=61.53, \mathrm{r}=0.37, \mathrm{p}=0.000)$ to yield. A positive association $(\mathrm{F}=50.8, \mathrm{r}=0.34, \mathrm{p}=0.000)$ was found between the plantain/banana and cocoa while a negative association $(\mathrm{F}=6.94, \mathrm{r}=0.13, \mathrm{p}=0.03)$ was found between maize/cassava and cocoa. Oil palm trees associated with cocoa contributed significantly $(\mathrm{F}=14.53, \mathrm{r}=0.19, \mathrm{p}=0.0002)$ in reducing yield. 


\section{Discussion}

Our results show that the transformation of traditional cocoa forest garden from extensive to intensive manage systems is associated with changed in abiotic and biotic habitat parameters with consequence on yield. Cocoa farming in southern Cameroon is dominated by smallholders who rely on family labour as the main source of labour for production. Family labour was the only type of labour employed on $84 \%$ of the farms in EO, $97 \%$ of EY, $75 \%$ of IY and $29 \%$ of IM with the proportion using only family labour significantly higher on extensive systems. Family children made a significant contribution to this labour pool. However, although the number of children was significantly correlated with farm size, farming experience and yield (number of cocoa bags harvested), on larger farms such as in intensive mature systems, an increasing proportion of cocoa farmers contract casual and permanent labour to meet additional labour demands. Most of these labour forces are adult migrants from neighboring Northwestern and Adamaoua provinces. Cocoa production requires many cultural practices that are labour intensive: about four weeding rounds per year, removal of mistletoes and other epiphytes, shade management through pruning, and removal of basal suckers. In addition to the cultural practices farmers should performed other labour intensive activities like applying pesticides, harvesting, opening the pods, fermenting and drying the beans. There are two options for cocoa farmers in southern Cameroon if he/she wants to meet his requirements, either to hire labour or to rely on family labour. The costs of hired labour are out of reach of most farmers or they are not willing to invest capital in labour. The higher labour requirement for young cocoa farms in combination with the labour shortage contributes to the difficulties farmers face in replacing their old cocoa farms as observed in extensive manage old TFG. Moreover, the current out-migration of the youth from their village to the cities due to lack of social amenities like electricity has aggravated the labour scarcity problem. Youth migration creates labour shortage, leading to high labour costs. Youth migration also leaves the aged farmers in the village to take care of the farms. The net effect of this factor is low productivity and incomes and reduced food security, child nutrition and household welfare.

Children employed in farms to help their parents are between 10 to 15 years old and are involved in hazardous tasks such as assisting in pesticide application (including fetching 
of water, mixing, spraying and clean up), field clearing with machetes, harvesting and picking of pods or carrying of heavy loads such as bags of cocoa beans with potential negative impact on their education. Average annual quantities of cocoa beans produced per household ranged from between $595.43 \mathrm{~kg}$ in EY to $2644.35 \mathrm{~kg}$ in IM with larger farms significantly using more children from within the family. On the other hand, the number of children associated with yield may be due to the social status of the farmers. In rural areas of southern Cameroon, having more than one wife is a sign of wealth and provide a high social rank, therefore a prosperous farmers will have more than one wife and consequently many children. Nevertheless, although it is very difficult and to some extend impossible to prevent or stop the involvement of children in helping their parents in cocoa farming, there is a need to sensitize cocoa farmers and farmers organizations on hazardous child labour but this issue requires a multi-sector focus and should not be viewed as a problem distinctive to the cocoa sector.

The increase knowledge or use of indigenous methods of pests and diseases control such as botanicals within educated farmers is due to their contact with other farmer organizations in and outside the country. After the liberalization, organized farmers sent representatives to Côte d'Ivoire and Ghana where they learn about the used of neem products, neem derivatives and other plant with insecticidal or fungicidal properties in treating their farms. When in Cameroon, they try to disseminate the knowledge amongst other farmers. The higher adoption of such knowledge by polygamous farmers may be just an economic strategy. Because they have higher farm size, they intent to reduce the cost of application of pesticides by combining it with plant extracts. This is exemplified by the fact that after the cocoa crisis, in response to the high price of inputs and the low price of cocoa, some farmers modify the input recommendations, while other decided not to apply any inputs at all. This involves mixing of insecticides or fungicides with plant extracts. The farmers believe that this mixing increases the effectiveness of the chemicals and improve yield (Sonwa et al., 2002).

Older and experienced farmers perceived millipedes as vector of black pod diseases. According to farmers the high motility of millipedes specifically during the wet season, moving from the ground to the cocoa canopy, may carry Phytopthtora megakarya spores and disseminate them in the canopy, therefore responsible for initiating infection in the cocoa canopy. Our findings suggest that epidemiological principles for black pod 
diseases seem to be well understood by farmers. Education that combines local knowledge with farmer's observational skills and management strategies would be potentially useful.

Significant litter cover was observed to improve yield. Local management strategies that improve the litter cover of TFG in southern Cameroon are fairly understood by cocoa farmers. Nevertheless, shade is the most important factor at a local scale and influence yield of most plantation crop (Amoah et al., 1997). The moisture and nutrient relation of crops and the chemical and physical properties of the soil are affected by shade trees through deposition of leaf litter and root growth (Carrière et al. 2002). To improve yield in TFG, we suggest proper management of shade through an increment that seek a balance between tree species richness and density and less intensive weed control thereby maintaining diverse herbaceous ground vegetation. A diverse herbaceous cover will provide a more heterogeneous habitat and resources to soil biota (decomposers and endophytic fungi), pollinators (Willmer and Stones, 1989; Klein et al., 2003), parasitoids (Sperber et al., 2004) and predators including ants (Khoo and Fee, 1989) that can used leaf litter as shelter.

Pod loss to mirids was higher with hybrid cultivars and in plantation near the village than those close to the forest. This suggests that loss to mirids depends primary on land-use intensity and only secondarily on the varieties grown. Distance from the forest may also be an important factor influencing yield (Klein et al., 2002), the proximity of the forest providing more refuge and habitat for parasitoids and predators (Majer, 1972, Beattie, 1985, Ribas et al., 2003, Sperber et al., 2004). Higher tree species richness and density provide more heterogeneous habitat and resources to predators and parasitoids. Species diversity and abundance of parasitoids, predators, or pollinators could be enhanced if TFG are located close to natural forest. Even small isolated forest fragments may help to retain diversity and increase the conservation value of TFG (Horner-Devine et al., 2003). Before the cocoa crisis, cocoa farmers were receiving subsidies from the Cameroon government in the form of pesticides (fungicides and insecticides). The cost for the service was recovered through a state-controlled cocoa marketing system (National Produce Marketing Board (NPMB)). Following the fall in price and liberalization of the marketing sector, the government withdrew the service abandoning the pesticides market in the hand of privates. Farmers are still reliant on pesticides use for pests and diseases 
control. Chemical control measures include the application of commercial insecticides (organophosphates, organochlorines, pyrethroids, carbamates and nicotinoids to name a few) and fungicides (copper based) available on the market. Some of the insecticides farmers used are classified as moderately to extremely hazardous. Their decisions to apply chemical are based on signs of damages or infections. However, farmers tend to overestimate damages and may apply control when it is not needed. Most of them still follow the old spraying calendar, hence the increase pod loss to mirids with increase type of commercial insecticides applied. Overall, farmers' current control practices suggest that a large proportion of the farmers' seem to be making inappropriate management decisions against mirids or black pods. Therefore IRAD (Institut de la recherche Agricole pour le Développement), the Cameroon governmental research institute involved in pesticides testing and homologation should seeks for ways, measures and alternative solutions satisfying farmers' interest. Education about pesticides, to which farmers are already exposed, would promote more selective, less dependent use and safer handling of such products and provide farmers a more objective basis for decisions about pesticide use in traditional cocoa forest gardens. A better understanding by farmers of basic pest and disease management principles would have major benefits for human health and the environment. Providing farmers' with new and indigenous/local knowledge would enable themselves to develop appropriate pest and diseases management strategies and make decisions as to which strategies to accept and demand. Farmers must be the primary players in changes affecting their life. Including farmers in the process of technologies development is less likely to end up being rejected or putting farmers into a reactive role and destroy the social tissues of their communities. Farmers' are very versatile and live in a dynamic system adjusting to changing circumstances. Their positive attributes should be acknowledged by expanding the knowledge and range of options available to them.

\section{Acknowledgments}

We thank the University of Goettingen (IPAG "International PhD Programme in Agricultural Sciences in Goettingen" and Entomology section) for financial support. Enumerators and key informants from farmers' organizations surveyed. 


\section{References}

Amoa, F.M., Osei-Bonsu, K. and Oppong, F.K. (1997) Response of improved robusta coffee to location and management practices in Ghana. Exp. Agric. 33, $103-111$.

Beattie, A. (1985) The evolutionary ecology of ant-plant mutualisms. Cambridge University Press, Cambridge.

Carrière M.S., Letourmy P. and Mckey D.B. (2002) Effects of remnant trees in fallows on diversity and structure of forest regrowth in a slash-and-nurn agricultural system in southern Cameroon. J. Trop. Ecol. 18: 375 - 396.

Duguma, B., Gockowski, J. and Bakala, J. (2001) Smallholder cacao (Theobroma cacao Linn.) cultivation in agroforestry systems of West and Central Africa: Challenges and opportunities. Agroforest Syst. 51, $177-188$.

Horner-Devine, M.C., Daily, G.C., Ehrlich, P.R. and Boggs, C.L. (2003) Countryside biogeography of tropical butterflies. Conserv. Biol. 17, 168 - 177.

ICCO (International cacao organization) (1997) Quarterly Bulletin of CACAO Statistics, June, ICCO, London

Khoo, KC. And Fee, GC. (1989) Use of the Black ant to control mirid damage in cocoa. The Planter 65, 370 - 383 .

Klein AM., Steffan-Dewenter, I. and Tscharntke T. (2002) Predator-prey ratios on cocoa along a land-use gradient in Indonesia. Biodivers. and Conserv. 11, 683-693.

Klein AM., Steffan-Dewenter, I. and Tscharntke T. (2003) Pollination of Coffea Canephora in relation to local and regional agroforestry management. J. of Appl. Ecol. 40, 837 - 845 . 
Losch B., Fusillier J.L. and Dupraz P. (1990) Strategies des Production en Zone Caféière et Cacaoyer du Sud Cameroun: Quelles adaptations à la crise? CIRAD, Département Systèmes Agraires, Montpellier Mack SD (1989) Livestock in Plantation Systems.

Majer, JD. (1972) The ant mosaic in Ghana cocoa farms. Bull. of Ento. 62, 151 - 160.

Ribas, CR., Schoereder, JH., Pic, M. and Soares, SM. (2003) Tree heterogeneity, resource availability, and larger scale processes regulating arboreal ant species richness. Austral Ecol. 28, 305-314.

Sonwa, D.J., O. Coulibaly, A. Adesina, S.F. Weise and M. Tchatat (2002) Integrated pest Management in cocoa agroforests in Southern Cameroon: constraints and overview. Integr. Pest Manage. Rev. 7(3), 191 - 199.

Sperber, CF., Nakayama, K., Valverde, MJ. and Neves, FS. (2004) Tree species richness and diversity affect parasitoid diversity in cacao agroforestry. Basic and Appl. Ecol. $\underline{5}$, 241-151.

SPSS Inc. 2004. Systat 11 for Windows. SPSS Inc., Chicago, IL.

Willmer, P.G. and Stone, G.N. (1989) Incidence of entomophilous pollination of lowland coffee (Coffea canephora); the role of leaf cutter bees in Papua New Guinea. Entomol. Exper. et Appli. 50, 113-124. 


\section{List of Figures}
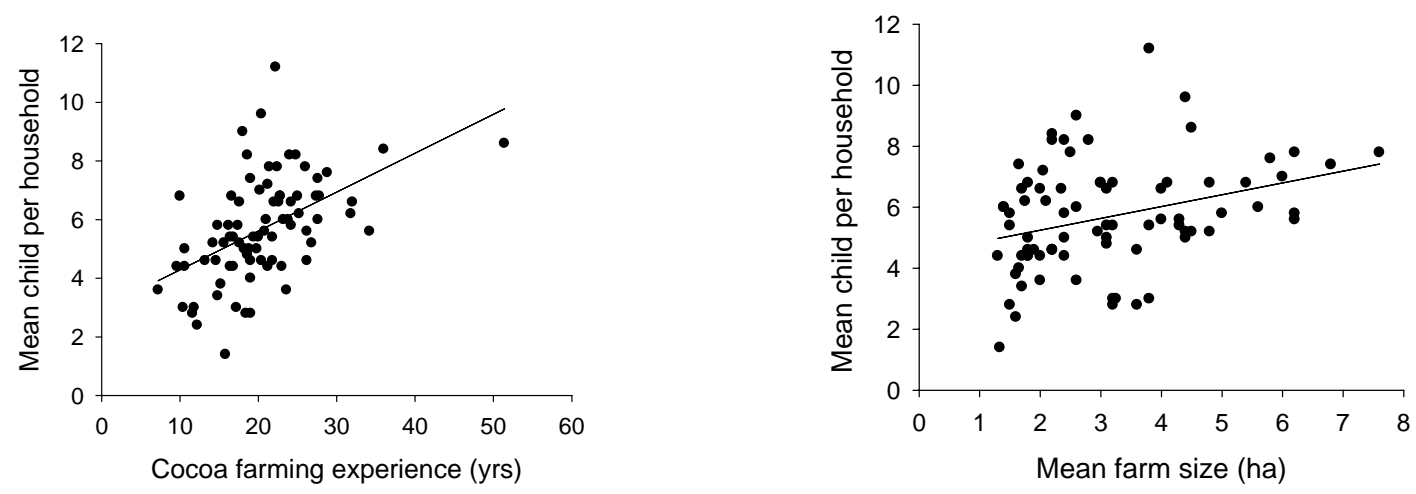

Figure 1. Relationship between number of children per household, cocoa farming experience and farm size
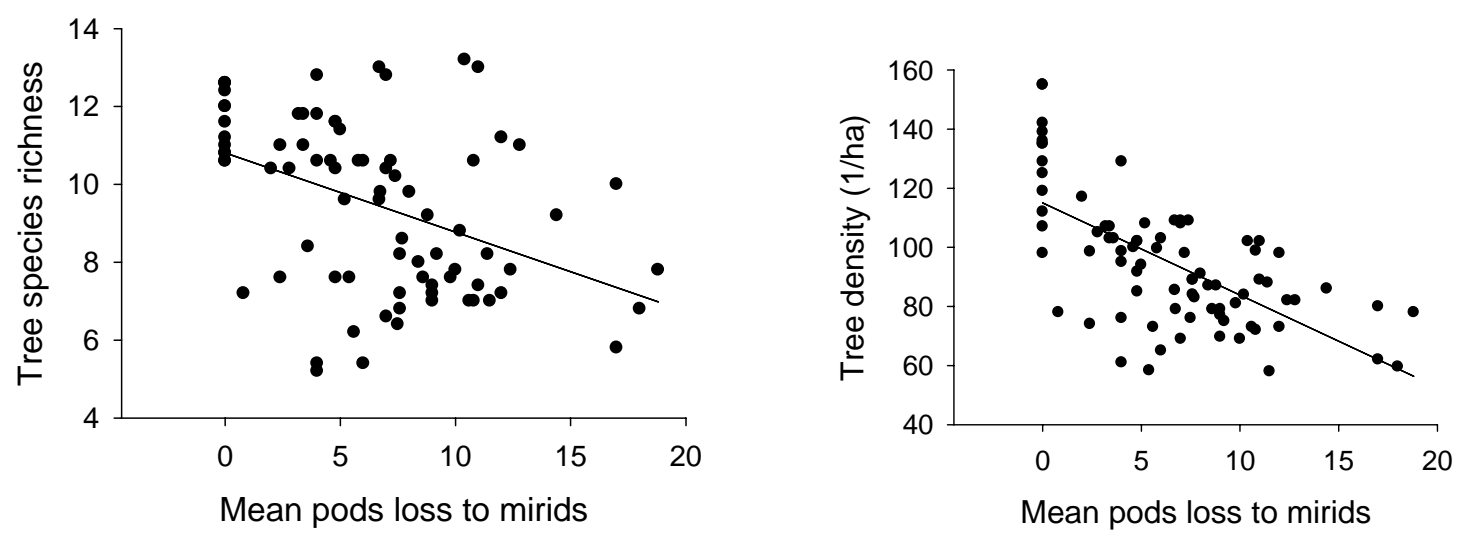

Figure 2. Relationship between pod loss to mirids and tree species richness and density 


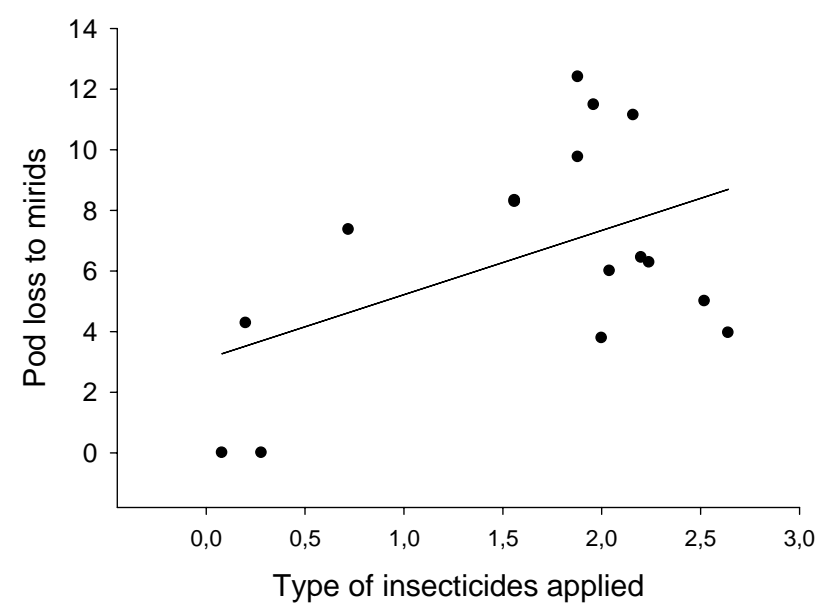

Figure 3. Correlation between pod loss to mirids and commercial type of insecticides applied by farmers

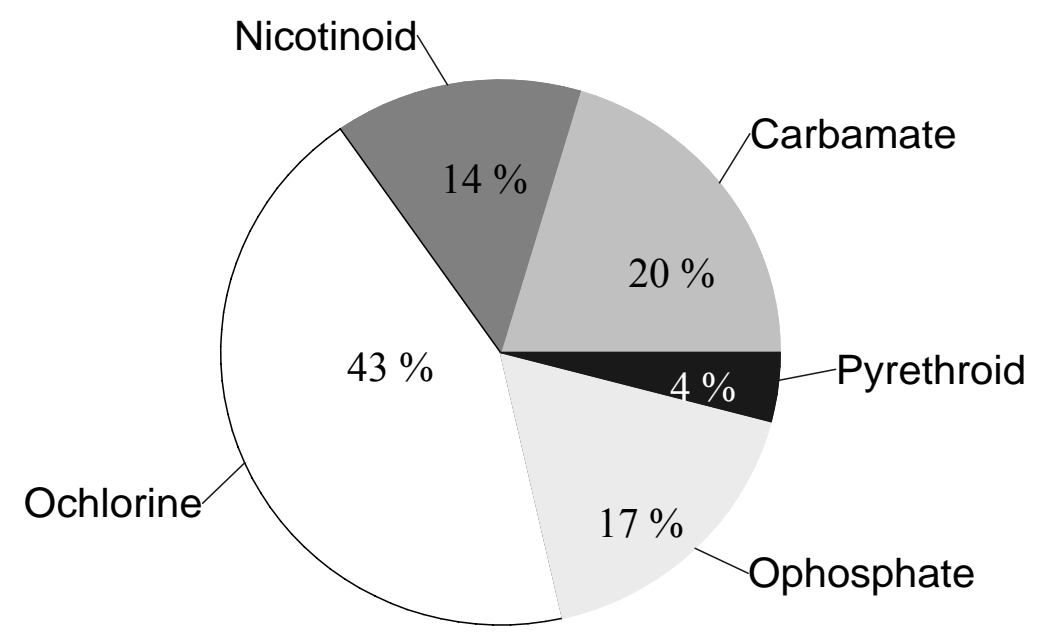

Figure 4. Most common class of insecticides sprayed by farmers (Ochlorine: Organochlorine; Ophosphate: Organophosphate) 

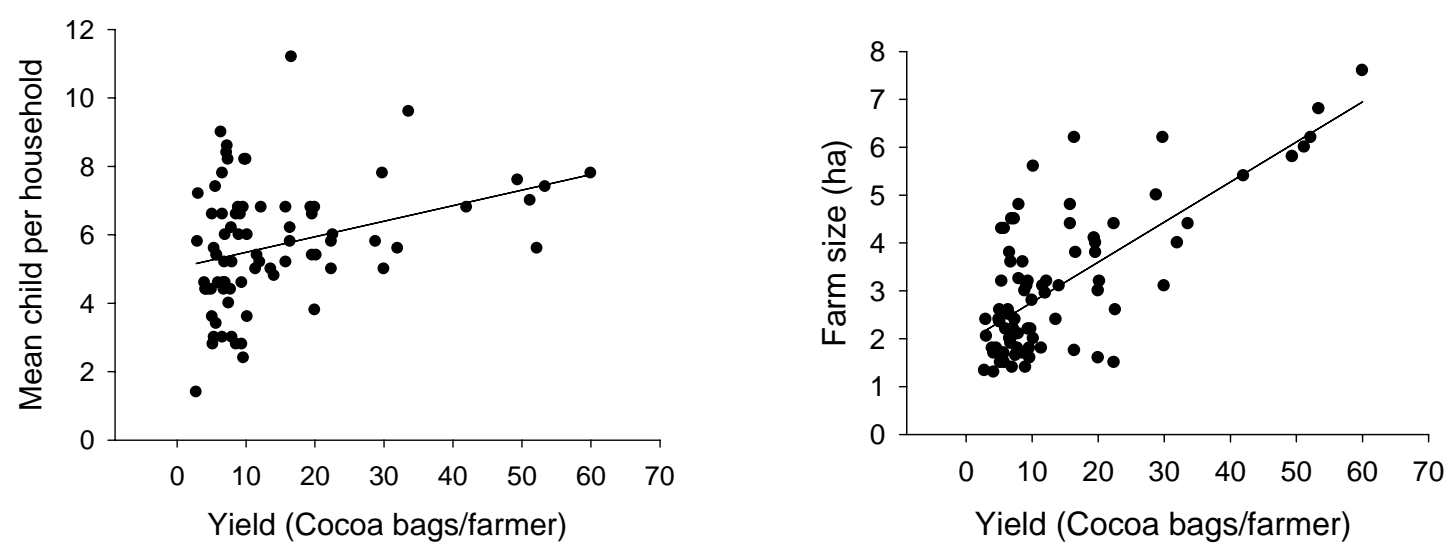

Figure 5. Influence of number of children per household and farm size on yield
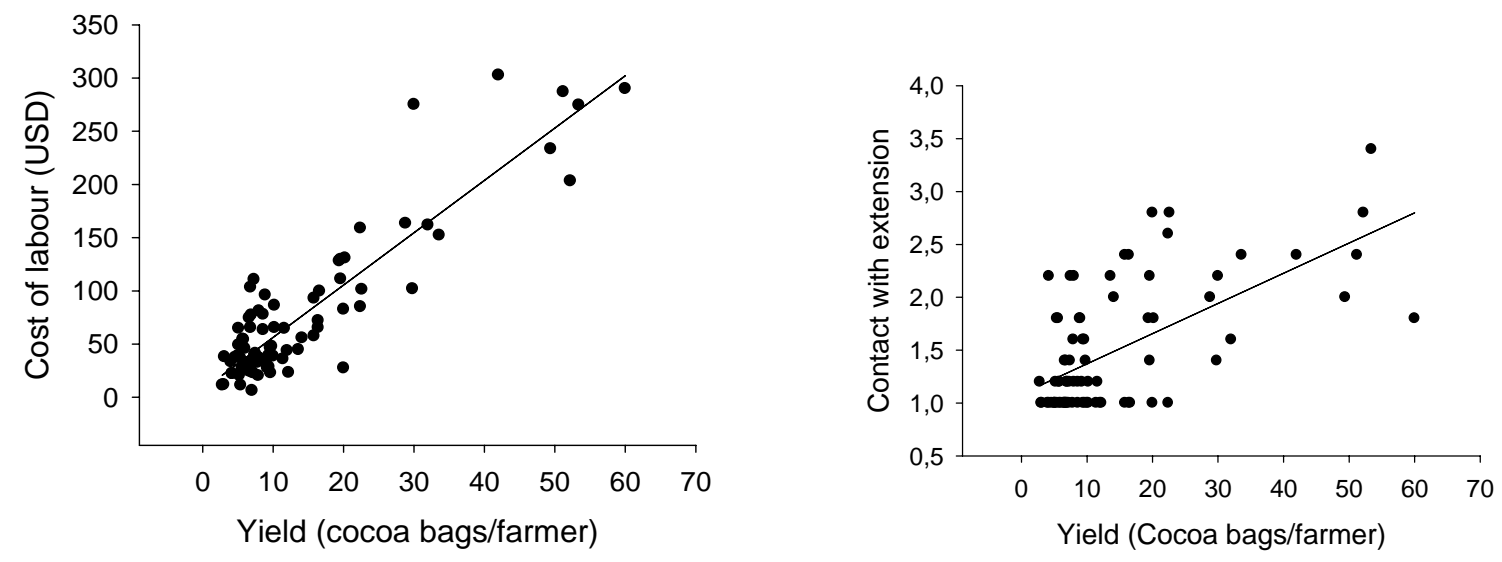

Figure 6. Relationship between the cost of labour, contact with extension services and yield in TFG (Cost of labour varies between 5 to 2000 USD; 1USD $=500 \mathrm{CFA}$ ) 


\title{
Sampling and temporal distribution of Salhbergella singularis (Haglung) (Hemiptera: Miridae) on cocoa
}

\author{
${ }^{1,2}$ Hervé D. B. Bisseleua and ${ }^{1}$ Stefan Vidal
}

${ }^{1}$ Georg-August-University Goettingen, Department of Crop Sciences, Entomological Section, Grisebachstr. 6, 37077 Goettingen, Germany; ${ }^{2}$ Institute of Agricultural Research for Development (IRAD), Nkolbisson Regional Research Centre, BP 2067, Yaoundé, Cameroon.

Corresponding author: Hervé D. B. Bisseleua; email: hbissel@gwdg.de

\begin{abstract}
The spatio-temporal distribution of Salhbergella singularis (Haglung) (SS) was studied for a two years period in traditional cocoa forest gardens in the humid forest area of southern Cameroon. A study of the temporal evolution of the number of SS revealed two rapid population increases during June-September and November-January. The overdispersion of SS was found to be significant during the two seasons. Three regression models, Taylor's power law, Iwao's patchiness regression, the nachman model and $k=c+d m\left[\mathrm{k}=m^{2} /\left(\mathrm{S}^{2}-m\right)\right]$ (where $k$ is the parameter for the negative binomial distribution) were used to analyze the data. Taylor's power law fit the data better than Iwao's and Nachman models. Taylor's $b$ and $\beta$ were both significantly $>1$, indicating that SS were aggregated. Iwao's $a$ was significantly $<0$, indicating that the basic distribution component of SS was the individual insect. The slope $d$ was indistinguishable from 0 , indicating the existence of a common $\mathrm{k}$ (estimated as 1.27544). The non binomial distribution model was appropriate for studying SS distribution based on comparison of NBD basis and Nachman's models. However, for accurate decisions based on mean numbers, we have developed and recommend a sequential sampling plan based on counts of mirid bugs on cocoa.
\end{abstract}


Keywords: mirid bugs, Theobroma cacao, dispersion, spatio-temporal model, negative binomial distribution,

\section{Introduction}

The cocoa mirid Salhbergella singularis Haglung (Hemiptera: Miridae) (SS) is a serious pest of cocoa in West and Central Africa (Collinwood 1977, Lavabre 1977). They occur at low overall densities but often aggregate in "pockets" where conditions are particularly favourable, e.g. a break in the shade canopy. There are five nymphal instars before maturity and all feed on cocoa seedlings, young shoots, cherelles, pods (immature and mature) and the cocoa trees causing serious crop damages, losses during the cherelle stage or cankers formation. Occasional damage accounts for 30 to $40 \%$ of pod losses. However, when foliage is affected, gradual wilting occurs and eventually, tree death (Pers. Observ).

Research efforts on SS were concentrated on bio-ecology (Williams 1953, Bruneau DeMiré 1977, Lotodé 1969 and Nwana \& Youdeowei 1978) and chemical control (Decazy 1979, Bruneau DeMiré 1985 and Coulibaly 1988). By late 80' it had become obvious that most of the recommendations extended to cocoa farmers on the control of SS have become inadequate and unsustainable. This was because SS have developed resistance to most insecticides that are widely used by farmers. These insecticides became expensive and less affordable, coupled with the destruction of non-target organisms creating upset in ecological balance.

Recently emphasis was placed on an integrated approach that is safer for the environment and adapted to the socio-economic conditions of smallholder cocoa farmers. In this regard, concerted research efforts were made to identify and evaluate various control techniques (cultural, biological, and chemical), which could be harnessed for integrated management of this most important pest.

Studies on the dispersion of SS were performed in many cocoa growing countries of West and Central Africa (Bruneau DeMiré 1977, Lotodé 1969 and Nwana \& Youdeowei 1978) with no emphasis on sampling methods. An understanding of the breeding and feeding sites of the pest is often necessary for selecting a sampling unit that is crucial for monitoring, forecasting and designing an IPM programme. Monitoring is very important 
for timing and evaluation of control measures. It is a mean for determining when pests enter the crops, when numbers have built up to sufficiently warrant control measures or to predict correct timing for such measures (Van-Emden, 1996). Control of SS must be based on knowledge of the life cycle and forecasts of population densities (Harcourt 1961, Iwao 1970, Sevacherian \& Stern 1972, Taylor 1984, Diana and Sannino, 1995) and temporal distribution. Methods that are commonly used to describe dispersion of arthropod populations have been summarized by Southwood (1978). Several estimates based on sample mean $(m)$ and variance $\left(S^{2}\right)$ (Taylor 1961, 1984; Iwao 1968, 1975) or based on sample mean $(m)$ and the proportion $p$ not infested (Nachman 1981, 1984) are used as indices for aggregation and the dispersion parameter $k$ for the negative binomial distribution (Southwood 1978). Moreover, these indices are often convertible from one to another. Sampling plans based on these descriptions of dispersion (Kuno 1969, Green 1970) reduce sampling effort and minimize variation of sampling precision (Hutchison et al. 1988, Kuno 1991, Trumble et al. 1989). Little is known about the dispersion of SS in cocoa plantations. To improve this knowledge, we collected data on the dispersion of SS on cocoa in the humid area of Southern Cameroon from 2003 to 2004 to assess if the mean population of SS can be estimated by taking into account only the presence/absence observations or individually counting the SS during sampling plans.

\section{Material and method}

\section{Study sites}

See Chapter 1 for summaries

\section{Sampling}

A daily "hand height" visual assessment was performed on 30 randomly selected cocoa trees per farm. We assess insect numbers on all parts of each selected tree by carefully inspecting from the base up to hand height level. The hang height level is the highest level to which the assessor's fully stretched hand can reach. Because SS are active very early in the morning before sunrise, inspection was done between 6.30 am and 8.30 am by looking at the nymphal and adult SS specifically at pod/stem interface, underneath pod 
peduncle and in crevices on individual cocoa trees. Their number per tree were counted and recorded.

\section{Statistical analysis}

Iwao's method

The Iwao's patchiness regression method quantifies the relationship between the mean crowding index $\left(m^{*}\right)$ (Lloyd's (1967) and mean $(m)$ by:

$$
m^{*}=\alpha+\beta m(1)
$$

where $m^{*}$ was determined as $\left[m+\left(S^{2} / m-1\right)\right]$ (Lloyd 1967). The intercept $(\alpha)$ is the index of basic contagion and the slope $(\beta)$ is the density contagiousness coefficient interpreted in the same manner as $b$ of Taylor's regression.

\section{Taylor's law}

The mean density $(m)$ per shoot and variance $\left(S^{2}\right)$ were calculated for trees in each field per sampling date and related to each other using Taylor's power law (Taylor 1961, 1971, Taylor et al. 1978).

Taylor's power law states that the variance $\left(S^{2}\right)$ of a population is proportional to a fractional power of the arithmetic mean $(m): S^{2}=a m^{b}$. To estimate $a$ and $b$, the values of $\ln \left(S^{2}\right)$ were regressed against those of $\ln (m)$ using the model

$$
\ln \left(S^{2}\right)=\ln (\mathrm{a})+\mathrm{b} \ln (\mathrm{m})(2)
$$

Where the parameter $a$ is largely a sampling factor related to sample unit size (Southwood 1978), the slope $b$ is an index of aggregation which indicates a uniform, random and aggregated dispersion when $b<1, b=1, b>1$, respectively.

\section{Nachman model}

In this model the proportion of sample units with no animal $\left(P_{0}\right)$ is related to the mean density $(m)$ as:

$$
P_{0}=1-\exp \left(-\mathrm{Am}^{\mathrm{B}}\right)(3)
$$


Where A and B are parameters of the model. The model is linearized with mean density ( $m$ ) regressed on $P_{0}$ (Nyrop et al. 1989) as:

$$
\ln (\mathrm{m})=\mathrm{A}+\mathrm{B} \ln \left(-\ln \left(P_{0}\right)(4)\right.
$$

To test the applicability of the negative binomial distribution, the proportion of sample units with no SS $\left(P_{0}\right)$ was calculated for different means using the two incidences and mean relationships and compared by chi square test.

\section{Non Binomial distribution model (NBD)}

The relationship between the proportion of samples with one or more animals (the incidence, $\left.P_{1}\right)$ and the density of animals $(m)$ per sample unit was developed by assuming that a negative binomial distribution (NBD) with variable $k$ would describe the distribution of SS on trees. This assumption was later tested. The NBD-based relationship was chosen because of the close relationship between NBD and Taylor's power law (Binns 1986). Estimated $S^{2}$ was described as a function of $m$ (Taylor 1961). With this relationship, $k$ of the NBD can be calculated as $\left[m^{2} /\left(a m^{b}-m\right)\right]$. The incidence is then one minus the zero term of the NBD (Wilson \& Room 1983, Nyrop et al. 1989):

$$
P_{1}=1-1\left[(1+m / k)^{k}\right](5)
$$

\section{Estimation of Common $k$ for the NBD}

The estimates of the dispersion parameter $k$ for the NBD, computed as $m^{2} /\left(S^{2}-\right.$

$m)$, were linearly regressed on $m$,

$$
k=c+d m(6)
$$

to test for the existence of a common $k\left(k_{c}\right)$ for each of the data sets (Southwood 1978, Feng \& Nowierski 1992). A $d$ value significantly $>0$ indicates the dependence of $k$ on mean density. The variance and mean within each area where the variance exceeded the mean were used to estimate $k_{c}$ for a negative binomial distribution (Fleischer et al. 1991). Estimates of $k_{c}$ were made using Elliot's (1977) techniques, which estimates $k_{c}$ by regressing $\mathrm{y}^{\prime}=\left(S^{2}-m\right)$ on $\mathrm{x}^{\prime}=\left(m^{2}-S^{2} / n\right)$, and $k_{c}$ was defined by $k_{c}=1 /$ slope. An index for spatial aggregation of arthropod populations, $1 / k$, which is equal to $m^{*} / m-1$ (Southwood 1978) and is the same as Cassie's index C (Cassie 1962), was also employed to evaluate the dispersion patterns. 


\section{Results}

\section{Temporal dynamic of infestation}

Mean density of SS decreased significantly in both $2003\left(\mathrm{~F}=17.45 ; \mathrm{R}^{2}=0.68 ; \mathrm{df}=4\right.$, $\mathrm{P}=0.003 ; \mathrm{y}=0.14 \mathrm{x}-0.12)$ and $2004\left(\mathrm{~F}=12.20 ; \mathrm{R}^{2}=0.60 ;\right.$ d.f. $=4, \mathrm{P}=0.008 ; \mathrm{y}=0.06 \mathrm{x}-$ 0.11 ) with intensification. Mean density of SS in samples ranged from 0.13 to 0.82 $(m=0.35 \pm 0.13)$ in 2003 and from 0.13 to $0.66(m=0.24 \pm 0.09)$ in 2004 per tree.

Mean annual rainfall varies from 19.18 to 51.45 in 2003 and from 18.75 to 65.92 in 2004 with young systems receiving significantly (ANOVA: $\mathrm{F}_{4,12}=6.98 ; \mathrm{P}=0.000$ ) less water. Population growth curves of SS on cocoa and rainfall pattern for the year 2003-04 are presented in Figure.1. An increase in the population of SS in 2003 and 2004 was observed firstly between June and August and secondly between November and January. An increase in rainfall was first observed between May/June the first year and March/April the second year and later between August and October in both years. Heavy rainfall was followed a month later by an increased in the population of SS in both 2003 and 2004. However we did not observed any significant effect of rainfall and temperature on the population growth of SS.

Variance-mean infestation rate relationship

Iwao, Taylor and Nachman relationships

The results of Iwao's regression of $m^{*}$ on $m$ is listed in Table 1. Iwao's patchiness regression described well the relationship between mean crowding and density for SS (Figure 2). The constant $a$ indicates the tendency to crowding ( + ve) or repulsion (- ve) defined as the 'Index of Basic Contagion' by Iwao (1970). For SS, the value of $a$ was $<0$ $(t=-0.30, d f=50, P<0.001)$ in 2003 and $>0(t=1.46, d f=60, P<0.001)$ in 2004, indicating that for adults the basic component of the population is a single individual. Estimate of $\beta$, the density contagiousness coefficient, was significantly $>1(t=3.76, d f=$ $50, P<0.001$ in 2003 and $t=15.29, d f=60, P<0.001$ in 2004).

Taylor's power law provided a highly significant relationship between variance $\left(S^{2}\right)$ and mean density (Table 2). Figure 3 shows the relationship between the mean, variance and infestation rate for year 2003-04. When the mean density increases, the variance also 
increases, meaning that the fluctuation of the number of SS per tree increases. The overdispersion of SS populations is significant as shown by the dispersion indices to be 3.57 in extensive old systems; 2.70 in intensive systems; 1.79 in extensive young systems and 2.23 in home gardens but did not differ among systems.

Taylor's intercept, $\ln (a)$, was significantly $>0(t=3.43, d f=50, P<0.001$ (2003); $t=$ 1.57, $d f=60, P<0.001$ (2004)) in 2003 and 2004. Estimate of $b$ was significantly $>1(t$ $=7.82, d f=50, P<0.001$ (2003); $t=19.71, d f=60, P<0.001$ (2004)). Taylor's model is $\mathrm{S}^{2}=\mathrm{m}^{1.5}$ for 2003 and 2004 respectively.

Nachman's model gave an excellent fit to the relationship between the proportion of tree without SS $\left(P_{0}\right)$ and mean density $(m)$ of SS (Table 3, Figure 4). Using the parameter estimates (Table 3), the proportion of tree with or without SS can be estimated from mean density with equation 4 . However, the coefficient of determination $\mathrm{R}^{2}$ is weak compared to the Iwao and Taylor models.

\section{Estimation of common $k$ for NBD}

Figure 5 gives an overall picture on the relationship between $k$ and the mean number of SS from the 37 and 40 samples where the variance exceeded the mean in 2003 and 2004 respectively. This value of $\mathrm{k}$ was 3.21 in 2003 and 2.50 in 2004 with the corresponding index of spatial aggregation (1/k) of 0.31 in 2003 and 0.40 in 2004. Regression of $k$ on the mean density per tree using all data was not significant in both 2003 and 2004 (F= $0.24, r^{2}=0.007, P=0.62$ (2003 and $F=0.77, r^{2}=0.02, P=0.39$ ) (Table 4). Moreover, the slope of regression $(d)$ was not significantly greater than $0(t=0.49, d f=37, P=0.62$ (2003) and $t=0.88, d f=40, P=0.39$ (2004)). Independence of $k$ with the mean density suggests the existence of common $k$ for the NBD of the SS populations. The estimate of a common k was 1.7544 using Elliot's (1977) method.

\section{Discussion}

In 2003 and 2004, SS population had almost similar development pattern with the first increase between June and September and the second between November and January. Burneau DeMiré in 1977 observed and increase in SS population between July and 
September in Southern Cameroon around the Mbalmayo forest reserve dominated by extensive old cocoa systems. The second increased observed in our study is attributed to the intensive cocoa systems with main production between September and December. Moreover, we also observed that the increase in the SS population was always observed two weeks and one month after heavy rainfall ie in mid- June and mid-November. Philpott et al. (2006) observed that in tropical area insects are very active during wet season and this could explained an increased of SS population after rain.

Taylor's power law generally fit the data better, yielding higher value of $R^{2}(0.90$ in 2003 and 0.80 in 2004) than Iwao's model (0.87 in 2003 and 0.63 in 2004) and Nachman model (0.60 in 2003 and 0.44 in 2004). The aggregation indices (slopes, b and $\beta$ ) of Taylor's power law and Iwao's patchiness regression were all significantly $>1(P<$ 0.001), indicating an aggregated dispersion distribution of SS. Taylor (1965) has suggested "that $b$ may reflect the behavioural interaction between organism and environment". In our study, the aggregation index $b$ varied and this variation may have been due to the interaction between SS, the management regime and their natural enemies i.e. parasitoids and predators and abiotic factors mainly rainfall. For example based on management index, we have identified three significantly different management systems among the traditional cocoa forest gardens (TFGs) studied: (1) The extensive manage old cocoa forest gardens (EO), with the lowest MI and higher shade cover, as well as tree species richness; (2) Extensive manage young cocoa forest gardens (EY) and Cocoa forest home gardens (HG), with intermediate MI; and (3) Intensive manage mature (IM) and young (IY) cocoa forest gardens, with the highest MI and lowest shade cover and tree species diversity. Slope coefficients $(b)$ did not differ among these TFGs. The causes of aggregation could be attributed to either active aggregation on the part of this SS (such as behavior and reproductive biology), or to some heterogeneity of the environment (such as microclimate, preferred part of plant, and natural enemies) (Southwood 1978). Although no data on SS is currently available for direct comparison, however, the observed values for $\beta$ and $b$ are similar to those for many moderately aggregated insects (Taylor 1961, 1971). Changes in the density of an insect often result in changes in the distribution (Southwood 1978). However, we did not detect apparent density-dependent distribution changes in the SS population (Fig. 5.). Similar results were reported by Feng \& Nowierski (1992) for the summer populations of Russian wheat aphid, Diuraphis noxia 
(Mordvilko), on winter wheat. The values of aggregation index $(1 / k)<,=$, and $>0$ represent regularity, randomness, and aggregation of populations in spatial patterns, respectively (Cassie 1962, Southwood 1978). In our study, 37 in 2003 and 40 in 2004 samples observations were $>0$. This indicates that the populations of SS generally were aggregated on cocoa trees. This further supports the results obtained using Taylor's power law and Iwao's models. However, the Taylor-power-law approach to sampling problems seems the most promising, since it has been shown to fit most sampling data and gives the most reliable parameters between different environmental habitats, different sampling methods, and overall potential changes in arthropod densities (Taylor, 1984).

Our experiment showed that the Taylor's model remain relatively stable over the two periods. For accurate decisions based on mean numbers, we have developed and recommend a sequential sampling plan based on counts of SS. This sequential sampling will be based on the Taylor's model with level of precision previously defined (Taylor's 1984). Presence/absence (binomial) sampling is faster, time saving and reduces sampling cost. In addition binomial sampling is the only feasible field-sampling method for insects such as SS. However due to the reported association of SS and black pod diseases caused by Phytophtora megakarya, further research on the interactions between theses two organisms is needed.

\section{Acknowledgments}

Financial assistance was provided by the University of Goettingen (IPAG "International $\mathrm{PhD}$ Programme in Agricultural Sciences in Goettingen") and "Le Ministère Français de la Cooperation" Through the SCCS project. We thank the staff of the Laboratory of Entomology at the "Institut de la Recherche Agricole pour le Développement" (IRAD) in Nkolbisson, Cameroon: M. Djalla, AD. Missoup, M. Mbenoum, V. Ondoua, J. Nzomo, JC. Mongo, N. Essomo, C. Ngoum Esse and V. Koumpia and smallholder cocoa farmers for help in the field. 


\section{References}

Binns M.R. (1986) Behavioral dynamics and the negative binomial distribution. Oikos 47: 315-318.

Bruneau de Miré P. (1977) La dynamique des populations de mirids et ses implications. In : Les mirides du cacaoyer. (Ed) Lavabre EM, GP Maisonneuve et Larose, Paris, 171 186.

Bruneau de Miré P. (1985) Enquête sur la tolérance des mirides du cacaoyer aux insecticides au Cameroun. Café Cacao Thé 29(3).183 - 196.

Cassie R.M. (1962) Frequency distribution models in the ecology of plankton and other organisms. J. Anim. Ecol. 31: 65-92.

Collingwood C.A. (1977) African mirids. In: Les mirids du cacaoyer. Ed. By Lavabre EM, GP Maisonneuve et Larose, Paris $71-76$.

Coulibaly N. (1988) Evaluation de l'éfficacité des traitements antimirides au Togo. Rapport de mission pour la SRCC (Société nationale pour la rénovation et le développement de la cacaoyère et la caféière togolaises), Togo, 22p.

Decazy B. (1979) Ombrage et traitements anti-mirides sur les cacaoyers : Leur influence sur la production. Proceedings of the $7^{\text {th }}$ International Cocoa research Conference, November 1979, Douala, Cameroon, pp 443 - 446.

Diana G. and Sannino L. (1995) Adversities of tobacco culture. Insect Informatore Fitopatologico, 45: 7-9, 24-31.

Elliot J.M. (1977) Some methods for the statistical analysis of samples of benthic invertebrates, 2nd ed. Freshwater Biological Association, Cambridge, U.K. 
Feng, M.G. and Nowierski R.M. (1992) Variation in spatial patterns of the Russian wheat aphid (Homoptera: Aphididae) among small grains in the northwestern United States. Environ. Entomol. 21: 1029-1034.

Fleisher S.J., Ravlin F.W. And Reardon R.C. (1991) Implementation of sequential sampling plans for gypsy moth (Lepidoptera: Lymantriidae) egg masses in eastern hardwood forests. J. Econ. Entomol. 84: 1100-1107.

Green R.H. (1970) On fixed precision level sequential sampling. Res. Popul. Ecol. 12: 249-251.

Harcourt D.G. (1961) Design of a sampling plan for studies on the population dynamics of the diamond-back moth, Plutella maculipennis (Curt.) (Lepidoptera: lutellidae). Canadian Entomol. 93: 820-831.

Hutchinson WD., Hogg DB., Asraf Poswal M., Berberet RC., and Cuperus G.W. (1988) Implications of the stochhastic nature of Kuno's and Green's fixed-precision stop lines: sampling plans for the pea aphid (Homoptera: Aphididae) in alfalfa as an example. J. Econ. Entomol. 81: 749-758.

Iwao S. (1968) A new regression method for analyzing the aggregation pattern of animal populations. Res. Popul. Ecol. 10: 1-20.

Iwao S. (1970) Problems in spatial distribution in animal population ecology, pp. 117149. In: G. P. Patil [ed.] Random counts in models and structures, 1. Pennsylvania State University Press, University Park. 268 pp.

Iwao S. (1975) A new method of sequential sampling to classify populationsrelative to a critical density. Res. Popul. Ecol. 16: 281. 
Kuno E. (1969) A new method of sequential sampling to obtain the population estimates with a fixed level of precision. Res. Popul. Eocl. 5: 31-43.

Kuno E. (1991) Sampling and analysis of insect populations. Annu. Rev. Entomol. 36: 285-304.

Lavabre E.M. (1977) Importance économique des mirids dans la cacaoculture mondiale. In : Les mirides du cacaoyer. Ed. By Lavabre EM, GP Maisonneuve et Larose, Paris, 139 -153 .

Lloyd M. (1967) Mean crowding. J. Anim. Ecol. 36: 1-30.

Lotodé R. (1969) Etude statistique de l'’evolution d'une population de mirides. Café Cacao Thé 13(3), 216-220.

Nachman G. (1981) A mathematical model of the functional relationship between density and spatial distribution of a population. J. Anim. Ecol. 50, 453 - 460 .

Nachman G. (1984) Estimates of mean population density and spatial distribution of Tetranychus urticae (Acari: Tetranychidae) and Phytoseiulus persimilis (Aarina: Phytoseiidae) based on the proportion of empty sampling units. J. Appl. Ecol. 21: 903913.

Nwana I.E. and Youdeowei A. (1978) The spatial distribution of three species of Heteroptera in a cocoa farm in Ibadan, Nigeria. Nigerian Journal of Entomology 3(1), 27 -33 .

Nyrop J.P., Agnello A.M., Kovach J. and Reissig W.H. (1989) Binomial sequential classification sampling plans for European red mite (Acari: Tetranychidae) with special reference to performance criteria. J. Econ. Entomol. 82: 482-490. 
Philpott S.M., Perfecto I. and Vandermeer J. (2006) Effects of management intensity and season on arboreal ant diversity and abundance in coffee agroecosystems. Biodivers. and Conserv. 15: $139-155$.

Sevacherian V. and Stern V.M. (1972) Spatial distribution patterns of Lygus bugs in California cotton fields. Environ. Entomol. 1: 695-704.

Southwood T.R.E. (1978) Ecological methods. London: Chapman and Hall. Pp.524.

Taylor L.R. (1971) Aggregation as a species characteristic, pp. 357-377. In: G. P. Patil, E. C. Pielou and W. E. Waters [eds.] Statistical ecology, vol. 1. Pennsylvania State University Press, University Park. 582 pp.

Taylor L.R. (1961) Aggregation, variance and the mean. Nature 189: 732-735.

Taylor L.R. (1984) Assessing and interpreting the spatial distribution of insect population. Annu. Rev. Entomol. 29: 321-358.

Taylor L.R., Woiwod I.P. and Perry J.N. (1978) The density-dependence of spatial behavior and the variety of randomness. J. Anim. Ecol. 47: 383-406.

Trumble J.T., Brewer M.J., Shelton A.M. and Nyrop J.P. (1989) Transportability of fixed-precision level sampling plans. Res. Popul. Ecol. 31: 325-342. Van-Emden, HF. 1996. Pest control. CAB. International. 150pp.

Williams G. (1953) Field observations of the Cacao mirids, Salhbergella singularis Hagl. and Distantiella theobroma (Dist.), in the Gold Coast. Part II: Geographical and Habitat Distribution. Bull. Ent. Res. 44, 427 - 437.

Wilson L.T. and Room P.M. (1983) Clumping patterns of fruit and arthropods in cotton, with implications for binomial sampling. Environ. Entomol. 12: 50-54. 


\section{List of Figures}
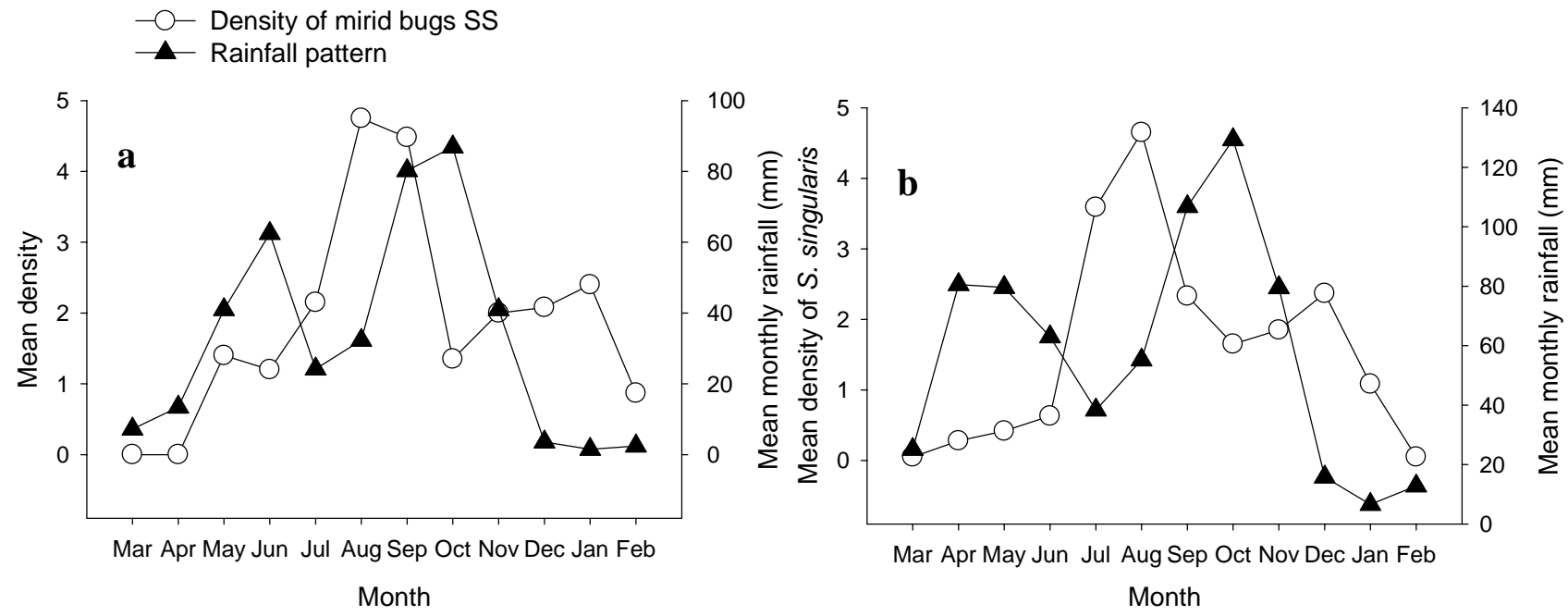

Figure 1. Population growth curve of S. singularis and rainfall pattern for year 2003 (a) and 2004 (b) in traditional cocoa forest gardens in southern Cameroon.
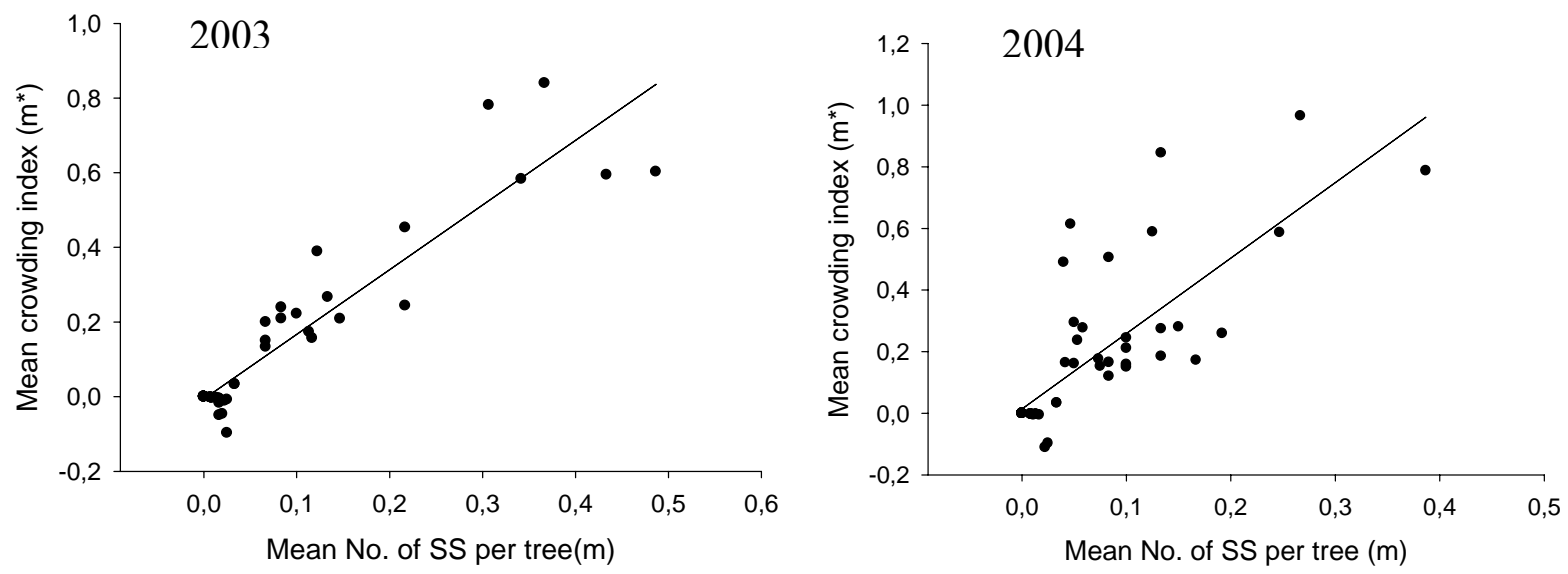

Figure 2. Regression analysis of Iwao's mean crowding index $\left(m^{*}\right)$ on mean density $(m)$ for SS populations on cocoa $\left(m^{*}=-0.18+1.73 m\right.$ in 2003 and $m^{*}=0.41$ $+2.45 \mathrm{~m}$ in 2004 , dots are estimated values based on observations). 

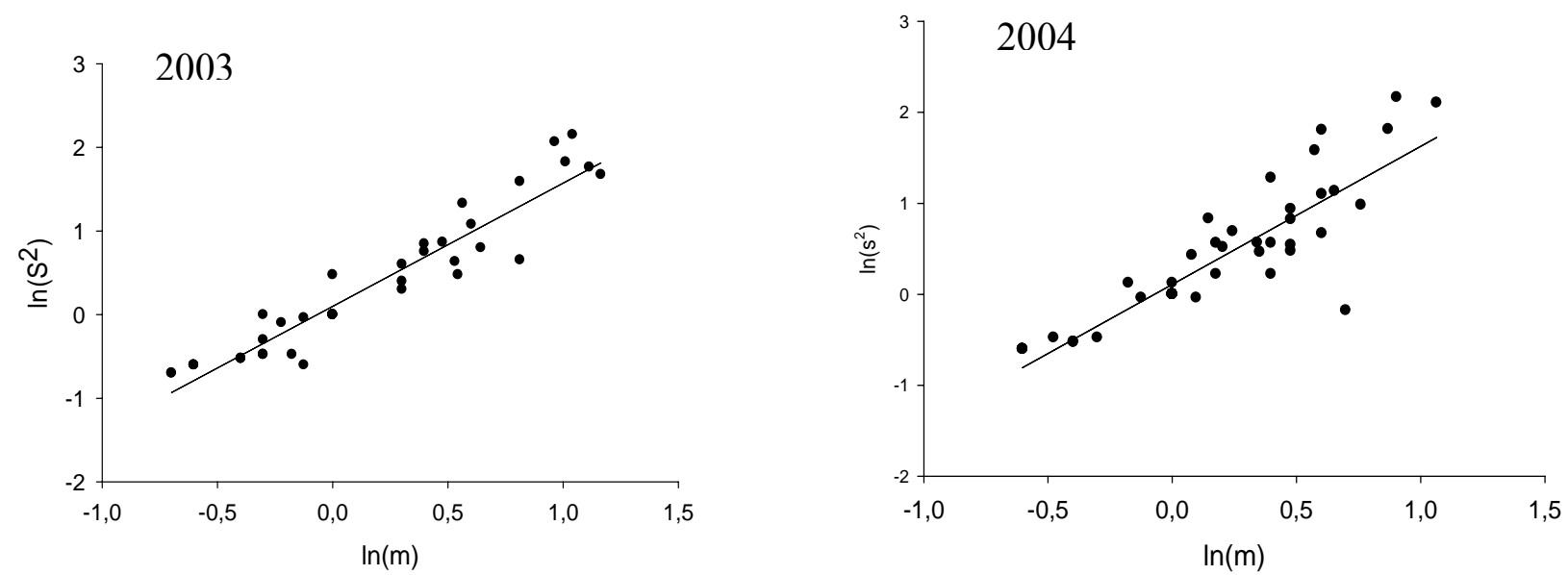

Figure 3. Regression analysis of Taylor's power law $(\ln (S 2)=\ln (0.10)+$ $1.50 \ln (m)$ in 2004 and $\ln (0.11)+1.50 \ln (m)$ in 2004) for SS populations on cocoa (dots are estimated values based on observations).
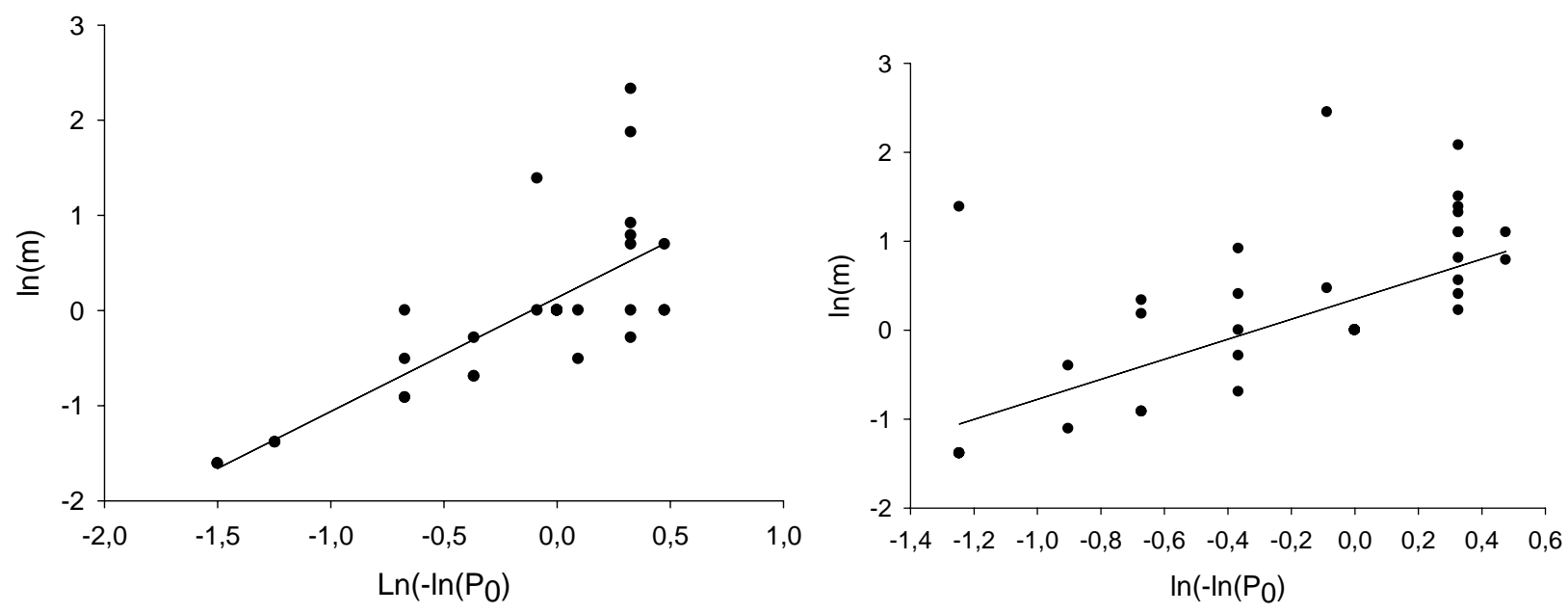

Figure 4. Regression analysis of Nachman's model $(\ln (m)=-0.15+0.51 \ln (-\ln (P 0)$ in 2003 and $\ln (\mathrm{m})=-0.25+0.39 \ln (-\ln (\mathrm{P} 0)$ in 2004) for SS populations on cocoa (dots are estimated values based on observations). 

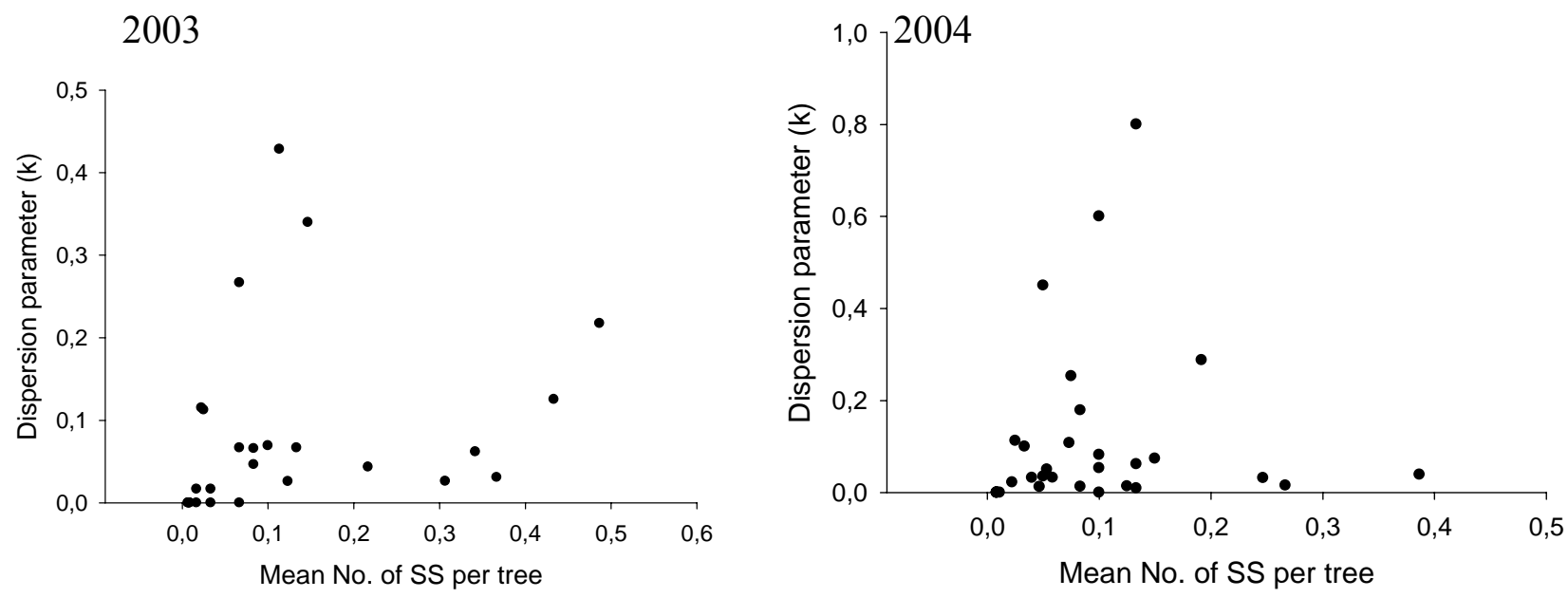

Figure 5. Scatter plots of $k$ for the NBD over mean $(m)$ for SS populations on cocoa in 2003 and 2004. 


\section{List of Tables}

Table 1. Estimation of Iwao's parameters

\begin{tabular}{|lcccc|}
\hline Year & $\mathrm{n}$ & $\alpha$ & $\beta$ & $\mathrm{R}^{2}$ \\
\hline 2003 & 50 & $-0.18 \pm 0.041$ & $1.73 \pm 0.010$ & $0.87^{* *}$ \\
2004 & 60 & $0.41 \pm 0.070$ & $2.45 \pm 0.025$ & $0.63 * *$ \\
The model is $m^{*}=\alpha+\beta m$ & & & & \\
$* *$ Significant at $\mathrm{P}<0.0001$ & & & & \\
$\mathrm{n} \quad$ is the number of week of & & & & \\
observations & & & & \\
\hline
\end{tabular}

Table 2. Estimation of Taylor's parameters

\begin{tabular}{|lcccc|}
\hline Year & $\mathrm{n}$ & $\mathrm{Ln}(\mathrm{a})$ & $\mathrm{b}$ & $\mathrm{R}^{2}$ \\
\hline 2003 & 50 & $0.10 \pm 0.04$ & $1.50 \pm 0.07$ & $0.90^{* *}$ \\
2004 & 60 & $0.11 \pm 0.04$ & $1.50 \pm 0.10$ & $0.80^{* *}$ \\
The model is $\mathrm{S}^{2}=\mathrm{am}^{\mathrm{b}}$ & & & & \\
$* *$ Significant at $\mathrm{P}<0.0001$ & & & & \\
$\mathrm{n} \quad$ is the number of week of & & & & \\
observations & & & & \\
\hline
\end{tabular}


Table 3. Estimation of the Nachman's parameters

\begin{tabular}{|lcccc|}
\hline Year & $\mathrm{n}$ & $\mathrm{A}$ & $\mathrm{B}$ & $\mathrm{R}^{2}$ \\
\hline 2003 & 50 & $-0.15 \pm 0.07$ & $0.50 \pm 0.07$ & $0.60^{* *}$ \\
2004 & 60 & $-0.25 \pm 0.05$ & $0.39 \pm 0.06$ & $0.44^{* *}$ \\
The model is $p=1-\exp \left(-\mathrm{Am}^{\mathrm{B}}\right)$ & & & & \\
$* *$ Significant at $\mathrm{P}<0.0001$ & & & & \\
$\mathrm{n} \quad$ is the number of week of & & & & \\
observations & & & & \\
\hline
\end{tabular}

Table 4. Estimation of $\mathrm{k}$ for the NBD parameters

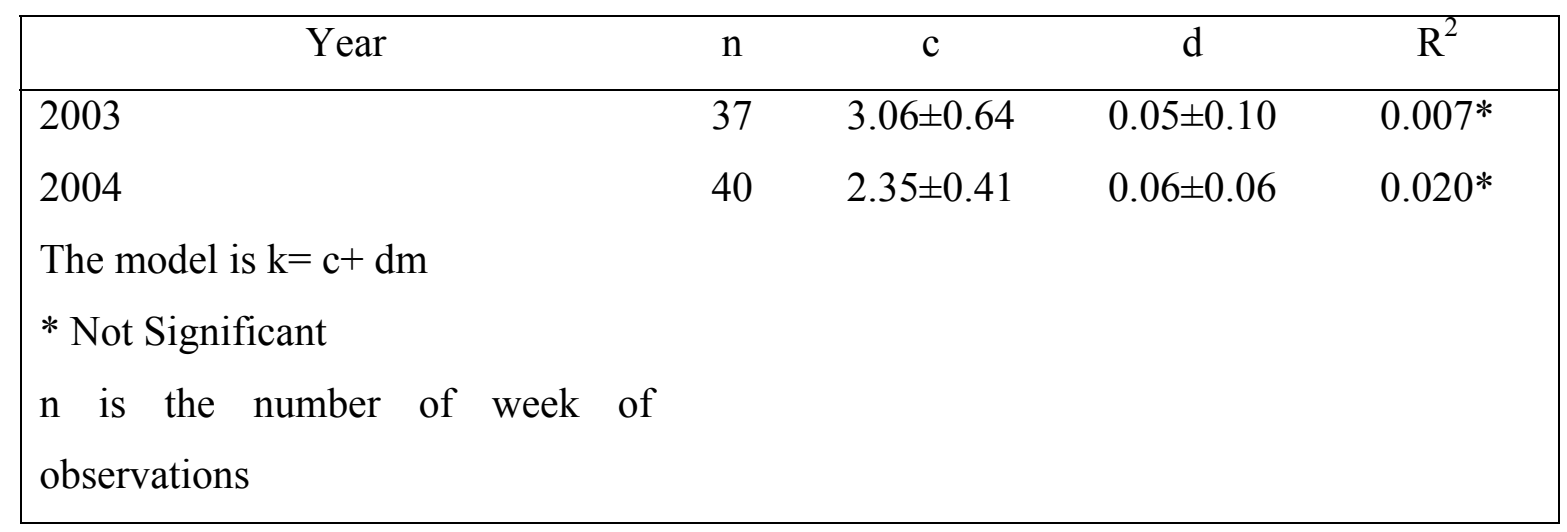


Chapter 6: Mutually exclusive interactions between mirid bug and a plant pathogen 118

\title{
Mutually exclusive interactions between a mirid bug and a plant pathogen on Cocoa trees
}

\author{
${ }^{1,2}$ Hervé D. B. Bisseleua and ${ }^{1}$ Stefan Vidal \\ ${ }^{1}$ Georg-August-University Goettingen, Department of Crop Sciences, Entomological \\ Section, Grisebachstr. 6, 37077 Goettingen, Germany; ${ }^{2}$ Institute of Agricultural Research \\ for Development (IRAD), Nkolbisson Regional Research Centre, BP 2067, Yaoundé, \\ Cameroon.
}

Corresponding author: Hervé D. B. Bisseleua; email: hbissel@gwdg.de

\begin{abstract}
Interactions between cocoa plants and their pests or plant diseases are generally analyzed without taking into account possible mutual interactions between the latter two organisms. We studied the tripartite interaction between the cocoa mirid Salhbergella singularis (Hagl.) (SS), the agent of the fungal black pod disease, Phytophthora megakarya Brasier and Griffin (BPD) and cocoa trees. The interactions between the insect and the plant pathogen appeared to be mutually exclusive in time and space, independent of different land-use management practices. High incidence of BPD was observed during April/June or September/November while SS populations rapidly increased during June/August or November/January. Adults of SS avoided feeding and ovipositing on fungus-infected trees or pods. Thus, we hypothesise that the incidence of BPD stimulated not yet known cocoa plant defense mechanisms that in turn influenced the host plant selection behaviour of SS. However, the observed host plant selection behavior of the bug releases SS from the popular notion of being a vector of BPD and adds to the diversity of interactions in traditional cocoa forest gardens. This is the first study to demonstrate that the relationship between a widespread mirid bug and a common plant pathogen is mutually exclusive, at least when seen from the bugs point of view.
\end{abstract}


Keywords: Cocoa, Salhbergella singularis, Phytophtora megakarya, antagonistic interactions, pathogens, plant-fungus-insect interactions.

\section{Introduction}

Patterns and processes in ecosystems are mediated by interactions between organisms and their biotic and abiotic environment (Yachi and Loreau 1999, Chapin et al. 2000, Duffy 2002, Giller et al. 2004, Perfecto et al. 2004, Philpott et al. 2005, Hooper et al. 2005, Philpott and Armbrecht 2006).

In the nature, Insects and pathogens occur simultaneously on the same host plant and plants often need to cope with both pathogens and herbivores. These herbivore-pathogen interactions can be classified as direct, indirect or mutualistic. The negative effect of such interactions on plant fitness will depend on the partial impact of each antagonist and also on the outcome of interactions between them. A pathogen infection can leads to an increase in the nutritional quality of the host (Kluth et al. 2002) or provide an additional source of sterols to the insect (Bernays 1992, Mondy and Corio-Costet 2000). Direct interactions are when the grazing of insects on fungal tissue or spores reduces plant disease caused by the pathogen (Kruess 2002). Moreover, the combine attack of both pathogens and herbivores can induce alterations of nutrient allocation patterns and defence-related compounds (Stout et al. 2006). An early fungal infection may induce resistance in plants against herbivory (Hatcher et al. 1995, Siemens and Mitchell-Olds 1999) or an herbivore-damaged plant may be unsuitable for fungi (Hatcher and Paul 2000). However, nothing is known about the interaction of Salhbergella singularis (Hagl.) (SS) and Phytophtora megakarya (Brasier and Griffin) on cocoa plants. SS is a serious pest of cocoa in West and Central Africa (Collinwood 1977, Lavabre 1977) and occurs at low overall densities but often aggregate in breaks in the shade canopy. They cause about 30 to $40 \%$ losses and in severe infestation tree death. Black pod disease (BPD) caused by P. megakarya (Nyasse 1992) is one of the most important limiting factors in cocoa production in southern Cameroon. Losses have been reported as high as $100 \%$ depending on location, cultivars (Nyasse et al. 2007) and present environmental conditions (Efombagn et al. 2004). 
Insect vectors are important dispersal agent of many plant pathogens. Furthermore, understanding transmission of fungi by insects is important for the management of crops. However, the role of rain and wind was recognized in the dissemination of black pod spores in cocoa plantations by Effombagn et al. (2004) and Ndoumbè et al. (2004). Recently, many cocoa farmers have suspected SS to be an active vector of black pod disease (Pers. Comm.).

In this study we analyse the interactions between SS and P. megakarya. We hypothesized that (i) SS might act as vector of black pod disease (BPD) caused by P. megakarya (ii) manipulating or controlling SS population will negatively influence the incidence of BPD.

\section{Material and method}

\section{Study sites}

Our surveys were conducted in semi-deciduous rainforest region of southern Cameroon in five major cocoa-growing regions with different management regimes as summarized in Chapter 1.

\section{Monitoring of black pod disease and sampling of SS}

In 2003 and 2004, we selected in each cocoa field and before flowering 30 randomly cocoa trees. These trees were monitored during the two year periods. On each tree we counted the number of flower cushion, the number of opened flowers and the number of cherelles produced. After cherelle production, trees were monitored daily to assess infection rate. Newly infected pods by $P$. megakarya were monitored daily from the base up to hand height level. The hand height level is the highest level to which the assessor's fully stretched hand can reach. Newly infected pods were counted and recorded. At the same time feeding damages caused by $S$. singularis (SS) on immature and mature pods were assessed to identify any possible implication of SS in the incidence of black pod disease.

A daily "hand height" visual assessment of SS was also performed on the same 30 selected cocoa trees per cocoa field. We assess insect numbers on all parts of each 
selected tree by carefully inspecting from the base up to hand height level. Because SS are active very early in the morning before sunrise, inspection was done between $6.30 \mathrm{am}$ and 8.30 am by looking at the nymphal and adult SS specifically at pod/stem interface, underneath pod peduncle and in crevasses on individual cocoa trees. Their number per tree were counted and recorded. Observations started at flowering and ended at harvest.

\section{Statistical analysis}

Statistical analysis of the data was performed using Systat 11 (SPSS Inc 2000). When necessary, logarithm or square root-transformed variables were used to meet normal distributions. We analyzed the number of infected pod, the population dynamic of SS, temperature and rainfall between TFGs using ANOVA with management regime as independent variable. When the model found statistically significant differences among TFGs, Tukey's post-hoc tests were used to determine which were significantly different. All other data were subjected to a factor analysis to determine the affinity between land uses. We used simple polynomial regression to assess the relationship between abiotic factors (Temperature and rainfall) and $P$. megakarya or SS and also between $P$. megakarya and SS. After the correlation analysis, interactions between P. megakarya and SS were studied in a spatial context. We adopted the weekly spatial scale. We considered that each selected tree could or could not be occupied, independent of the number infected pod or SS per TFG. For each week considered and in each site per TFGs, trees occupied by SS or with infected pods or with both received the value of "1", and the unoccupied trees (free of any infection or infestation) received the value " 0 ". As an example, if in a given week a mirid bug SS is recorded on a tree with no $P$. megakarya " 1 " is assigned to that tree under SS and "0" under P. megakarya (PM). If P. megakarya is recorded, independent of the number of infected pod, " 1 " is assigned to that tree under PM and "0" under SS. If SS and PM are recorded on the same tree, "1" is assigned to that tree and "0" to SS and PM respectively. By logistic regression (Sokal and Rohlf 1995), we determined whether the proportion of trees occupied by each cocoa plant natural enemies increased or decreased significantly through timed, with "time" used as independent variable. After the computation of the analysis a Friedman non parametric test was used to check if the models were well representative. 
Chapter 6: Mutually exclusive interactions between mirid bug and a plant pathogen 122

\section{Results}

\section{General description}

Cumulative results from 2003 and 2004 of the mean pod density, the number of infected pod by $P$. megakarya, the mean number of SS per tree; and the mean annual temperature and rainfall among TFGs are summarized in Table 1. IY recorded the highest number of pods produced and EO the lowest. However, no significant difference was observed between the mean pod densities among TFGs. Significant difference was observed between the mean number of infected pods by $P$. megakarya $($ d.f. $=4, F=3.74, P=0.007$ ) and the mean number of SS (d.f. $=4, F=5.83, \mathrm{P}=0.000$ ) among TFGs. We recorded a variation in the mean annual temperature among TFGs, but these values were not significantly different. However, a significant difference (d.f. $=4, \mathrm{~F}=6.98, \mathrm{P}=0.000$ ) was recorded in rainfall (Table 1).

\section{Spatio-temporal variation in infection and infestation patterns}

The mean pod density at five TFGs plotted with the infected pods, the population growth of SS and rainfall with the respective months are summarized in Figure 1 and Figure 2. Highest pod density was recorded in all systems between August and January.

The general trend observed in 2003 and 2004 was that model of the epidemiology of $P$. megakarya and that of the population growth of SS differ between TFGs. The observed model indicated an increasing trend in the epidemiology of P. megakarya in extensive systems from April to August in both years (Figure 1 and 2). Home garden cocoa forests (HG) showed a different model of the epidemiology of P. megakarya in 2003 (Figure 1). However, either in 2003 or 2004, the model was similar in the extensive young and intensives systems (Figure 1 and Figure 2). In addition to the general trend described above, changes in the epidemiology of $P$. megakarya coincided with changes in the rainfall patterns (Figure 1 and Figure 2). Observations on the population growth curves of SS on cocoa plants for the years 2003 and 2004 in TFGs are presented in Figure 1 and Figure 2. The growth curves model differ between TFGs in both years with populations of SS reaching their peak generally one month before high pod density is recorded. This observation is more peculiar to extensive systems and home gardens (Figure 1 and Figure 
2). On the other hand, higher population density of SS was recorded during the period of high pod density (i.e. between August and January) in intensive systems in both years, except in 2004 where an early peak was recorded in intensive young systems (Figure 2). Moreover, unlike with P. megakarya, changes in the growth model of SS did not coincide neither with changes in the rainfall patterns nor with changes in the epidemiology of $P$. megakarya.

To understand the tri-partite relationship between pod density, the number of infected pod and population growth of $S$. singularis, we perform a regression analyses with pod density as independent variable. Population growth of SS increased significantly $\left(\mathrm{R}^{2}=\right.$ $0.56, \mathrm{y}=0.15+10^{-3} \mathrm{x}, \mathrm{P}=0.005$ ) with pod density in 2003 , whereas number of infected pod by $P$. megakarya showed no significant correlation with pod density during the same year (Figure 3a). On the other hand, we observed no relationship between the mean number of infected pod by $P$. megakarya and the population growth of SS during the same year. However, in 2004 we observed a positive but not significant relationship between $P$. megakarya and SS, while $P$. megakarya showed a significant correlation with pod density $\left(\mathrm{R}^{2}=0.42, \mathrm{y}=0.08+5.10^{-4} \mathrm{x}, \mathrm{P}=0.02\right)$ (Figure $\left.3 \mathrm{~b}\right)$.

To evaluate the impact of abiotic factors on the incidence of P. megakarya or the population growth of SS, we studied the influence of temperature and rainfall on the two plant enemies. We observed no effect of temperature and rainfall on the population growth of SS in both years (Figure 4). The epidemiology of P. megakarya was significantly correlated with rainfall in both $2003\left(\mathrm{R}^{2}=0.87, \mathrm{y}=4.57+94.40 \mathrm{x}, \mathrm{P}<0.0001\right)$ and $2004\left(\mathrm{R}^{2}=0.33, \mathrm{y}=35.88+139.64 \mathrm{x}, \mathrm{P}=0.03\right)$ (Figure 4$)$. We also noticed a decrease in the incidence of $P$. megakarya with increasing temperature.

\section{Interactions of $P$. megakarya and $S$. singularis on cocoa trees}

From the cumulative curves of the mean pod density, temporal evolution of $P$. megakarya, the population growth of SS and annual rainfall with respective months (Figure 5), we observed no clear relationship between the epidemiology of P. megakarya and the population growth curves of $S$. singularis.

When the proportion of trees occupied by the two plant natural enemies in TFGs was investigated as a function of time, a clear increasing trend in the proportion of trees occupied by $S$. singularis was observed, with a concomitant decrease of trees occupied by 
P. megakarya (Figure 6). This effect was more intense in 2004 than 2003. Although the trend line was stiffer for $P$. megakarya than that of $S$. singularis, the logistic regressions were not significant $\left(\mathrm{P}=0.07, \mathrm{R}^{2}=0.44\right.$ for $P$. megakarya and $\mathrm{P}=0.38, \mathrm{R}^{2}=0.14$ for $S$. singularis).

A decrease in the proportion of cocoa trees occupied by $P$. megakarya and a significant increased of those occupied by $S$. singularis was observed in 2003 (Chi2= 39.08 $\mathrm{P}<0.0001)$ and slightly in $2004(\mathrm{Chi} 2=33.56, \mathrm{P}<0.0001)$ (Figure 7). These results reinforce the results previously shown in Figure 6. We observed from Figure 7 that either in 2003 or 2004 less than $0.20 \%$ of trees were occupied by both P. megakarya and S. singularis.

\section{Discussion}

This study demonstrated that the interaction between $S$. singularis and P. megakarya was mutually exclusive because the two organisms colonize cocoa plants at different periods of the year. Therefore SS do not vector black pod disease caused by P. megakarya or their feeding damages on cocoa pods are not entry point for P. megakarya infection. Our study also showed that SS have developed mechanisms to avoid trees previously infected by $P$. megakarya. Because feeding on infected pods might affect larval weight and developmental time (Rostás and Hilker 2002), females of SS could be expected to prefer healthy over infected pods as oviposition sites in order to provide optimal conditions for their offspring. The prolongation or abortion of larval development on infected pods may have significant ecological consequences. Slow-growing larvae may suffer greater mortality caused by parasitoids, predators or entomopathogens as predicted by the "slowgrowth, high mortality" hypothesis (Feeny 1966). However, contrasting results on the effects of pathogenic fungus on adult herbivores were reported by Courtney and Kibota (1990), Moran (1998) and Hatcher et al. (1994). Kluth et al. (2002) reported an antagonistic interaction between Cassida rubiginosa and Puccinia punctiformis on Cirsium arvense.

In year of low incidence of P. megakarya (2004), the population growth of SS increased significantly and decreases with increasing incidence of P. megakarya in September and 
November (Figure 5 and Figure 6). This phenomenon is exemplified by the higher proportion of trees (Figure 7) colonized exclusively by SS during that year. The few trees with both SS and P. megakarya, mainly in the later part of the year, might be explained by considering that adult females may have placed their eggs on formerly healthy plants, these becoming infected later. This would not allow hatching larvae to escape from infected trees. Many studies have reported the negative effects of endophytic fungi on herbivorous insects (Clay 1988, Raps and Vidal 1998) or their mutualistic effects (Zebitz 1990, Kluth et al. 2001, Kluth et al. 2002, Mondy and Corio-Costet 2004). For example, aphids, another group of sucking insects, are reported to favour and develop better on infected plants than healthy ones and benefit from the increase in free amino-acid concentration in the phloem. We would have expected SS another sucking insect to behave similarly and exploit plant metabolites produced by infected plants. Our results suggest that $P$. megakarya has an indirect negative impact on SS by stimulating unknown plant defense mechanisms that repel SS from feeding or ovipositing on infected cocoa trees.

Moreover, observations in cocoa field showed that pods with SS feeding damages are not or very rarely attacked by $P$. megakarya and vice-versa substantiating the mutually exclusive interactions between the two organisms. However, so far there is no study to assess the performance of SS and the impact of herbivory on fungal growth and reciprocally.

Compared to the general assumption that wind transport is the predominant mode of dispersion of $P$. megakarya spores; our results also demonstrated the importance of rainfall in the incidence of $P$. megakarya. Philpott et al. (2006) reported that in tropical area, insects, specifically ants, are very active during wet season. On the other hand, the role of ants as vector of P. megakarya was recognized by Evans (1973), Taylor and Griffin (1981) in Nigeria. Babacauh (1982) in Cote d'ivoire, Dibog (Pers. Comm.) in Cameroon, McGregor and Moxon (1985) in Papua New Guinea and Khoo and Ho (1992) in Malaysia. Therefore we suspect that activity of ants in the wet season due to more resources available (Honeydews, fresh plant materials and preys), combined with their association with soil splash (Efombagn et al. 2004) are responsible for the dissemination of $P$. megakarya resulting in the rapid increase of $P$. megakarya incidence one week after 
heavy rainfall. However, research remains unclear on the mechanisms and conditions under which ants vector P. megakarya.

We conclude that in cocoa plantation, the interaction between $S$. singularis and $P$. megakarya was mutually exclusive and was independent of land-use management. $P$. megakarya by being the first to colonize cocoa trees stimulate not yet known plant defense mechanisms that influenced the host selection behaviour of SS. However, the observed host plant selection behavior of the bug releases SS from the popular notion of being a vector of $P$. megakarya and adds to the diversity of interactions in traditional cocoa forest gardens. Rainfall impact $P$. megakarya and insects such as ants that are very active in wet season may help in the dissemination of $P$. megakarya resulting in a significant increase in the incidence of $P$. megakarya one week after heavy rainfall. Further studies are required to assess under laboratory conditions the performance of SS and the impact of herbivory on fungal growth and vice-versa or the mechanisms and conditions under which ant's vector P. megakarya.

\section{Acknowledgments}

Financial assistance was provided by the University of Goettingen (IPAG "International PhD Programme in Agricultural Sciences in Goettingen") and "Le Ministère Français de la Cooperation" Through the SCCS project. We thank the staff of the Laboratory of Entomology at the "Institut de la Recherche Agricole pour le Développement" (IRAD) in Nkolbisson, Cameroon: M. Djalla, AD. Missoup, M. Mbenoum, V. Ondoua, J. Nzomo, JC. Mongo, N. Essomo, C. Ngoum Esse and V. Koumpia and smallholder cocoa farmers for help in the field.

\section{References}

Babacauh, K.D. (1982) Rôle des communautés d'insectes et de l'eau dans la dissémination de Phytophthora palmivora (Butl.) Bult. Emend. Bras. Et Griff. Dans les cacaoyères de la Côte d'Ivoire. Café Cacao Thé, 1, 31-36.

Bernays E.A. (1992) Plant sterols and host-plant affiliations of herbivores. Insect-Plant Interactions, Vol IV (ed. By E.A. Bernays), pp 45 - 57. CRC Press, Boca Raton, FL. 
Chapin F.S. III, Zavaleta E.S., Eviner V.T., Naylor R.L., Vitousek, P.M., Reynolds H.L., Hooper D.U., Lavorel S., Sala O.E., Hobbie S.E., Mack M.C. and Diaz S. (2000) Consequences of changing biodiversity. Nature, 405, 234-242.

Clay K. (1988) Fungal endophytes of grasses: a defensive plant mutualism between plants and fungi. Ecology, 69, $10-16$.

Collingwood CA. (1977) African mirids. In: Les mirids du cacaoyer. Ed. By Lavabre EM, GP Maisonneuve et Larose, Paris $71-76$.

Courtney S.P. and Kibota R. (1990) Mother doesn't know best: selection of hosts by ovipositing insects. Insect-Plant Interactions, Vol. II (ed. By E.A. Bernays), pp. 161 181. CRC Press, Boca Raton, FL.

Duffy J.E. (2002) Biodiversity and ecosystem function: The consumer connection. Oikos, $99,201-219$.

Efombagn, M.I.B., Marelli, J.P., Ducamp, M., Cilas, C., Nyasse, S., \& Vefonge, D. (2004) Effect of fruiting traits on the field resistance of cocoa (Theobroma cacao L.) clones to Phytophthora megakarya. J. of Phytopath. 152, 557-562.

Evans, H.C. (1973) Invertebrate vectors of Phytophthora palmivora, causing black pod disease of cocoa in Ghana. Ann. of Appl. Biol. 75, 331-345.

Feeny P.O. (1976) Plant apparency and chemical defense. Biochemical interactions between plants and insects (recent advances in Phytochemistry, Vol 10) (ed. By J.W. Wallace and R.L. Mansell), pp. 1 - 40. Plenum New York.

Giller P.S., Hillebrand H., Berninger U-G., Gessner M.O., Hawkins S., Inchausti P., Inglis C., Leslie H., Malmqvist B., Monaghan M.T., Morin P.J., O'Mullan G. (2004) Biodiversity effects on ecosystem functioning: emerging issues and their experimental test in aquatic environments. Oikos, 104, $423-436$. 
Hatcher P.E. and Paul N.D. (2000) Beetle grazing reduces natural infection of Rumex obtusifolius by fungal pathogens. New Pathologist, 146, 325 - 333.

Hatcher P.E., Ayes P.G. and Paul N.D. (1995) The effect of natural and simulated insect herbivory, and leaf age, on the process of infection of Rumex crispus L. and $R$. obtusifolius L. by Uromyces rumicis (Schum.) Wint. New Phytologist, 130, 239 - 249.

Hatcher P.E., Paul N.D., Ayres, P.G. and Wittaker J.B. (1994) The effect of a foliar disease (rust) on the development of Gastrophysa viridula (Coleoptera: Chrysomelidea). Ecol. Entomol. 19, 349 - 360.

Hooper D., Chapin F.S.III., Ewel J., Hector A., Inchausti P., Lavorel S., Lawton J., Lodge D., Loreau M., Naeem S., Schmid B., Setälä H., Symstad A., Vandermeer J. and Wardle D. (2005) Effects of biodiversity on ecosystem functioning: a consensus of current knowledge. Ecol. Monographs, 75, 3 - 35 .

Khoo K.C. and Ho C.T. (1992) The influence of Dolichoderus thoracicus (Hymenoptera: Formicidae) on losses due to Heliopeltis theivora (Heteroptera: Miridae), black pod disease, and mammalian pests in cocoa in Malaysia. Bull. Entomol. Res. 82, 485 - 491.

Kluth S., Kruess A. and Tscharnkte T. (2001) Interactions between the rust fungus Puccinia punctiformis and ectophagous and endophagous insects on creeping thistle. J. of Appl. Ecol. 38: 548 - 556.

Kluth S., Kruess A. and Tscharnkte T. (2002) Insects as vectors of plant pathogens: mutualistic and antagonistic interactions. Oecologia, 133: 193 - 199.

Kruess A. (2002) Indirect interaction between a fungal plant pathogen and a herbivorous beetle of the weed Cirsium arvense. Oecologia, 130, $563-569$. 
Lavabre E.M. (1977) Importance économique des mirids dans la cacaoculture mondiale. In : Les mirides du cacaoyer. Ed. By Lavabre EM, GP Maisonneuve et Larose, Paris, 139 $-153$.

McGregor A.J. and Moxon J.E. (1985) Potential for biological control of tent building species of ants associated with Phytophthora palmivora pod rot of cocoa in Papua New Guinea. Ann. of Appl. Biol. 107, 271 - 277.

Mondy N. and Corio-Costet M.F. (2000) The response of the grape berry moth (Lobesia botrana) to a dietary phytopathogenic fungus (Botrytis cinerea): the significance of fungus sterols. J. of Ins. Physiol. 46, 1557 - 1564.

Mondy N. and Corio-Costet M.F. (2004) Feeding insects with a phytopathogenic fungus influences their diapause and population dynamics. Ecol. Entomol. 29, 711-717.

Moran P. (1998) Plant-mediated interactions between insects and a fungal plant pathogen and the role of plant chemical responses to infection. Oecologia, 115, $523-530$.

Nboumbè-Nkeng, M., Cilas, C., Nyemb, E., Nyasse, S., Bieysse, D., Flori, A., \& Sache, I. (2004) Impact of removing diseased pods on cocoa black pod caused by Phytophthora megakarya and on cocoa production in Cameroon. Crop Protec. 23, 415-424.

Nyasse, S. (1992) Structure d'une population de Phytophthora sp. Des cacaoyères camerounaises atteintes de pourriture brune. DRU Sciences agronomiques, Institut National Polytechnique de Toulouse.

Nyasse, S., Efombagn, M.I.B., Kébé, B.I., Tahi, M., Despréaux, D., \& Cilas, C. (2007) Integrated management of Phytophthora diseases on cocoa (Theobroma cacao L): Impact of plant breeding on pod rot incidence. Crop Protec. 26, $40-45$. 
Perfecto I., Vandermeer J.H., Bautista G.L., Ibarra Nuñez G., Greenberg R., Bichier P., and Langridge S. (2004) Greater predation in shaded coffee farms: The role of resident neotropical birds. Ecology, 85, 2677 - 2681.

Philpott S. and Armbrecht I. (2006) Biodiversity in tropical agroforests and the ecological role of ants and ant diversity in predatory function. Ecol. Entomol. 31, $369-377$.

Philpott S., Greenberg R., and Bichier P. (2005) The influence of ants on the foraging behavior of birds in an agroforest. Biotropica, 37, 468 - 471.

Philpott SM., Perfecto I. and Vandermeer J. (2006) Effects of management intensity and season on arboreal ant diversity and abundance in coffee agroecosystems. Biodivers. and Conserv. 15, $139-155$.

Raps A. and Vidal S. (1998) Indirect effects of an unspecialized endophytic fungus on specialized plant-herbivorous insect interactions. Oecologia, 114, $541-547$.

Rostás M. and Hilker M. (2002) Asymmetric plant-mediated cross-effects between a herbivorous insect and a phytopathogenic fungus. Agric. and Forest Entomol. 4, 223 231.

Siemens D.H. and Mitchell-Olds T. (1996) Glucosinolates and herbivory by specialist (Coleoptera: Chrysomelidae, Lepidoptera:Plutellidae): consequences of concentration and induced resistance. Envir. Entomol. 25, 1344 - 1353.

Sokal R.R. and Rohlf F.J. (1995) Biometry. New York: W.H. Freeman and Company.

Stout J.M., Thaler J.S. and Thomma P.H.J.B. (2006) Plant-mediated interactions between pathogenic microorganisms and herbivorous arthropods. Ann. Rev. of Entomol. 51, 663 689. 
Taylor, B. \& Griffin, M.J. (1981) The role and relative importance of different ant species in the dissemination of black pod disease of cocoa. In: P.H. Gregory \& A. C. Maddison (Eds), Epidemiology of Phytophthora on Cocoa in Nigeria (pp. 114-131), Wallingford, $\mathrm{UK}: \mathrm{CAB}$.

Yachi S. and Loreau M. (1999) Biodiversity and ecosystem productivity in a fluctuating environment: The insurance hypothesis. Proc. Nat. Acad. Sci. 96: 1463 - 1468. 


\section{List of Figures}
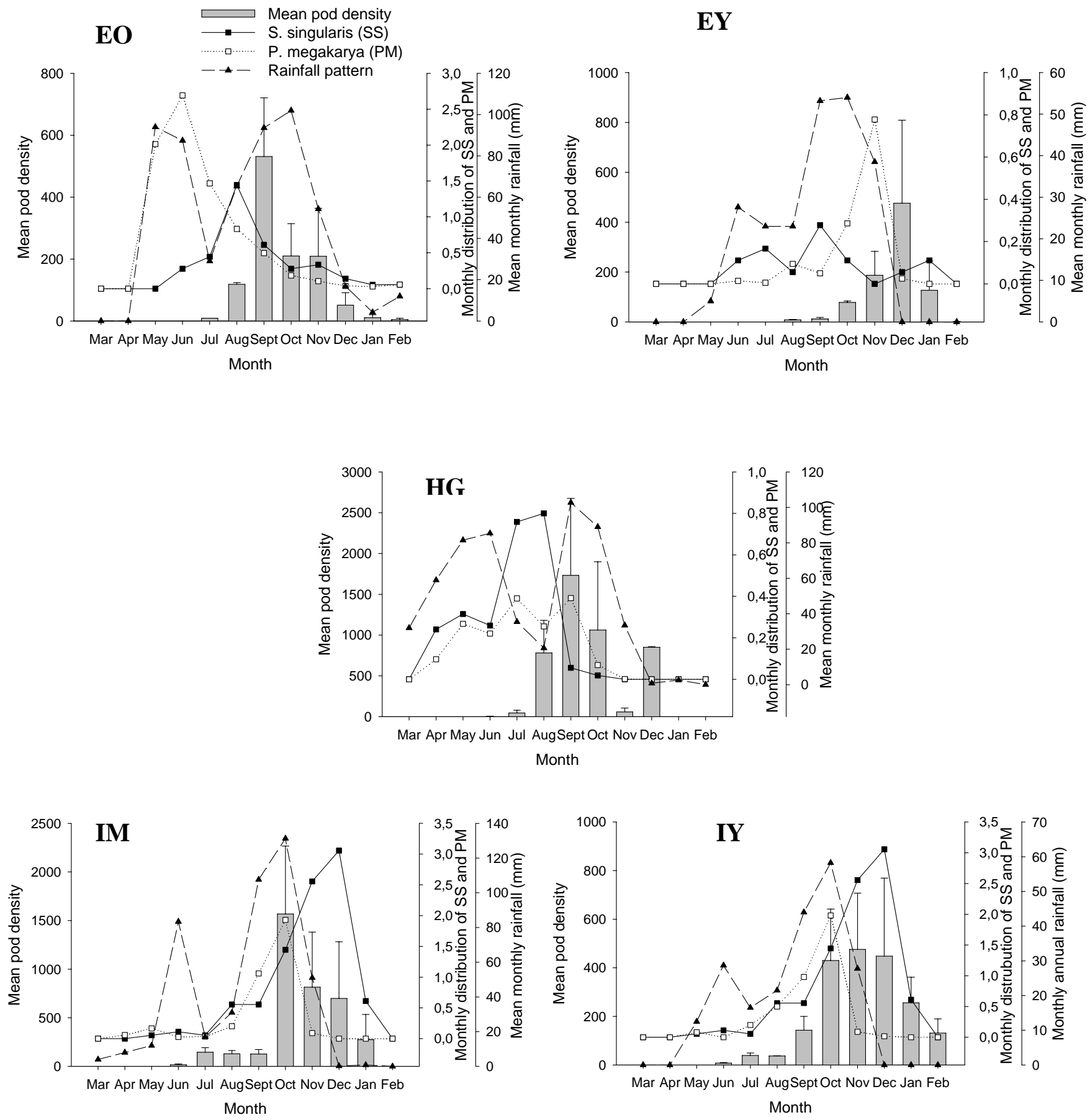

Figure 1. Mean pod density (left axes), epidemiology of P. megakarya and population growth curve of $S$. singularis (right axes) with rainfall pattern (right axes offset) recorded during the year 2003 in five traditional cocoa forest gardens (TFGs). EO: Extensive old TFGs; EY: extensive young; HG: Home gardens cocoa; IM: Intensive mature; and IY: Intensive young. 

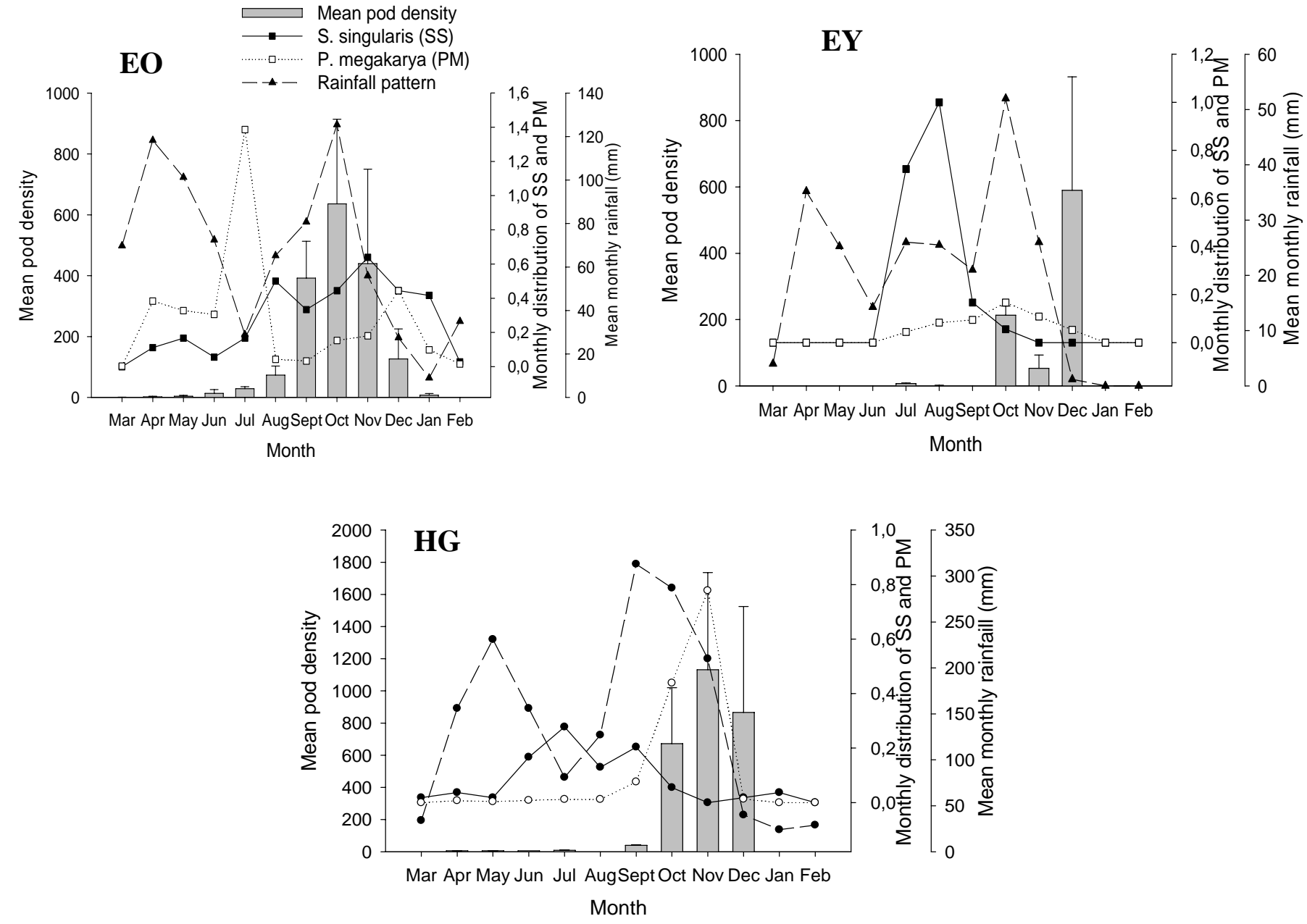

IM

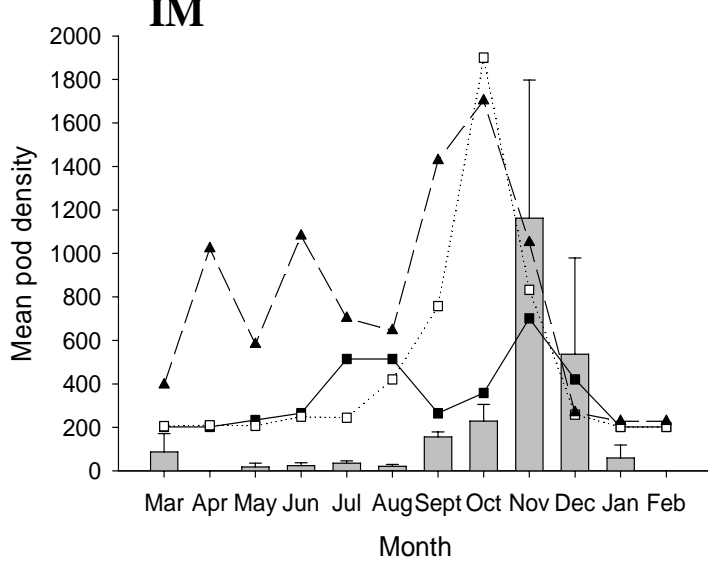

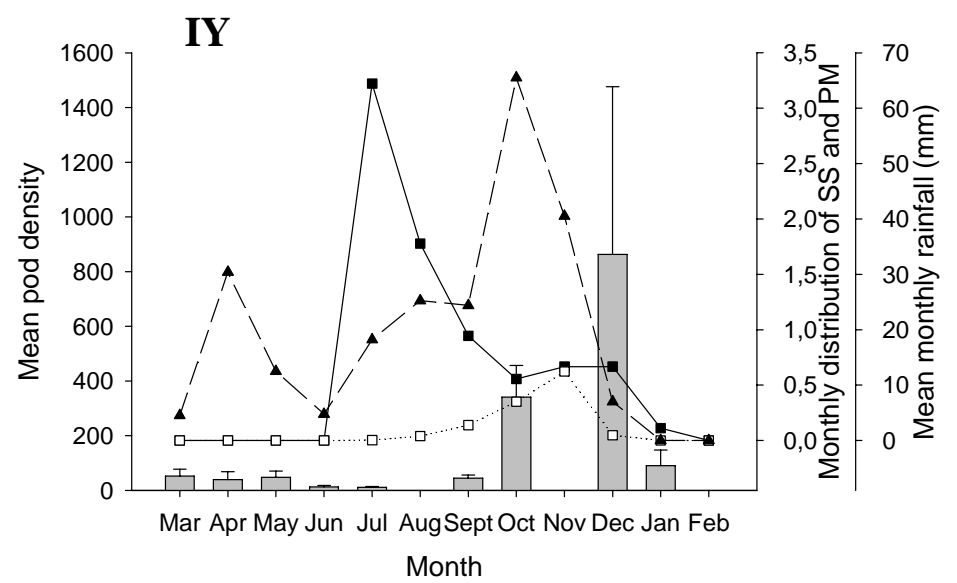

Figure 2. Mean pod density (left axes), epidemiology of P. megakarya and population growth curve of $S$. singularis (right axes) with rainfall pattern (right axes offset) recorded during the year 2004 in five traditional cocoa forest gardens (TFGs). EO: Extensive old TFGs; EY: extensive young; HG: Home gardens cocoa; IM: Intensive mature; and IY: Intensive young. 

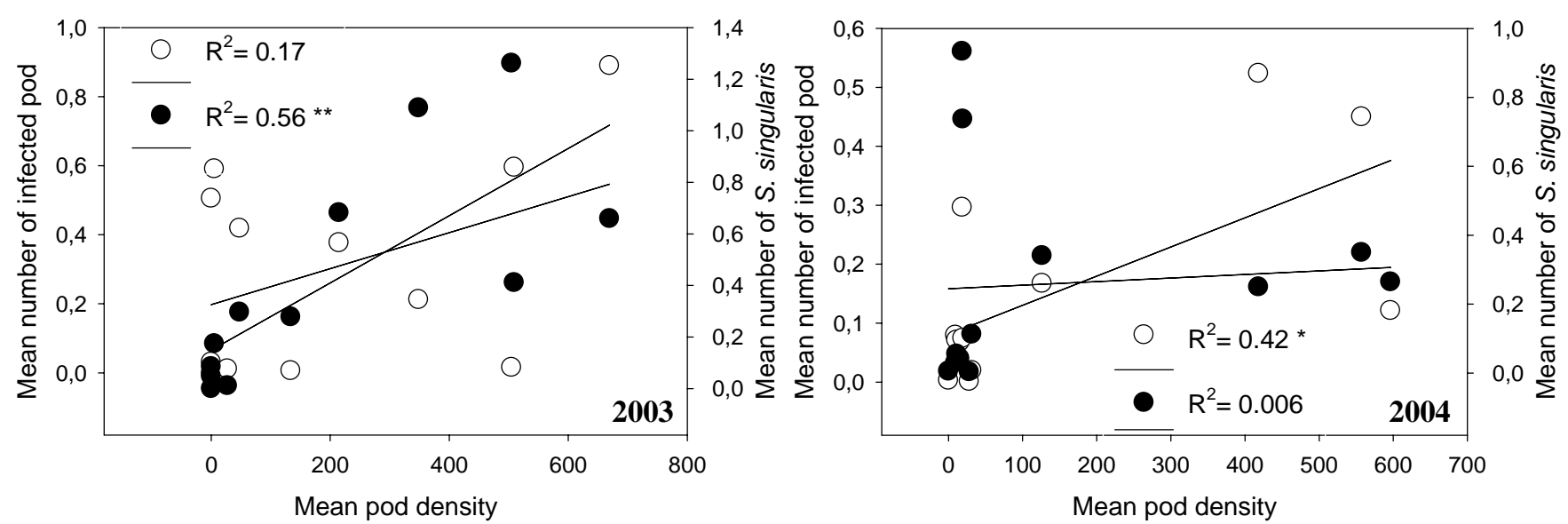

Figure 3. Relationship between monthly numbers of infected pod by P. megakarya (open circle), monthly population growth of $S$. singularis (close circle) and monthly pod density in traditional cocoa forest gardens in 2003 and 2004. $\mathrm{R}^{2}$ values are based on linear regressions $(* \mathrm{P}<0.05 ; * * \mathrm{P}<0.01)$. Pod density refers to the number of mature and ripe pods harvested per month.
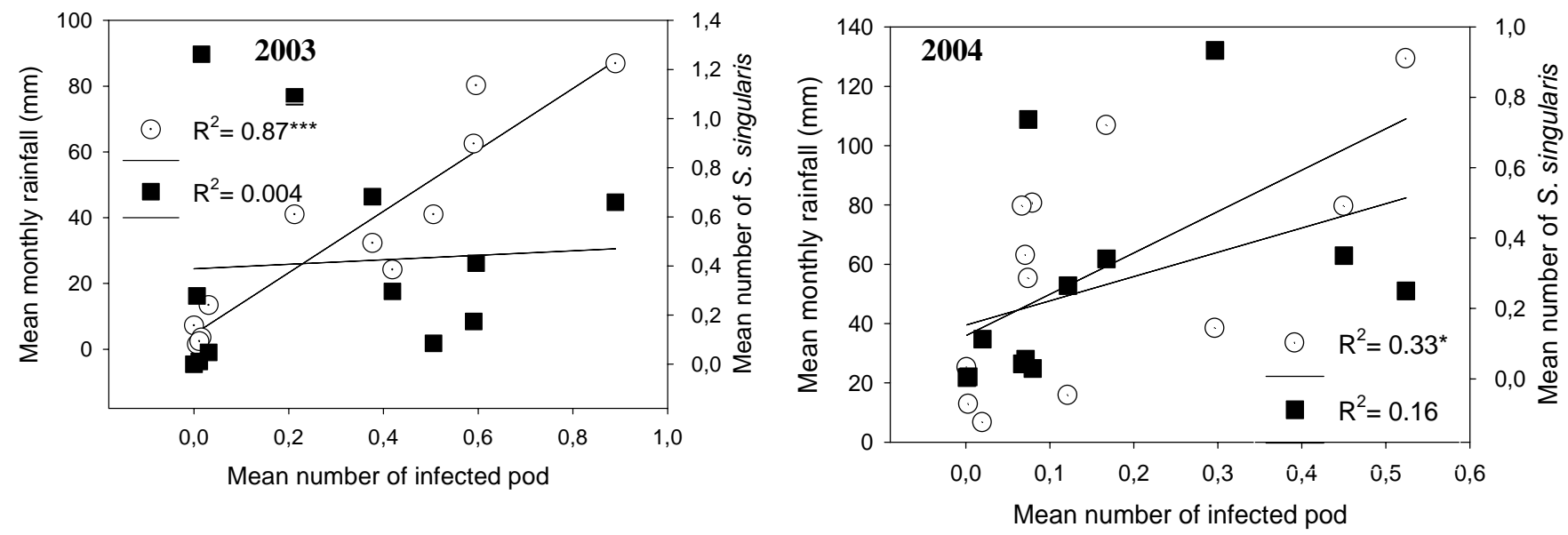

Figure 4. Influence of rainfall (open dotted circle) and the monthly population growth of S. singularis (close square) on the monthly number of infected by P.megakarya in 2003 and $2004 . \mathrm{R}^{2}$ values are based on linear regressions $(* \mathrm{P}<0.05 ; * * * \mathrm{P}<0.0001$. Rainfall refers to the average amount of rain recorded each month in 2003 and 2004. 

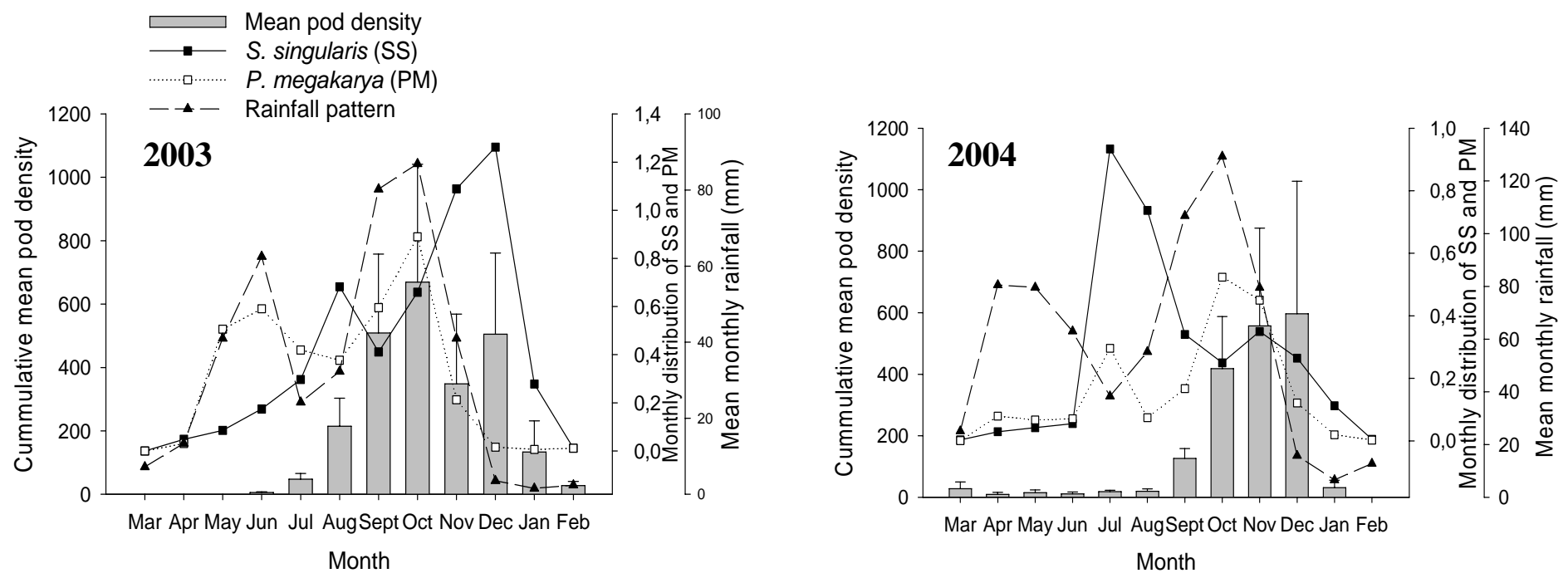

Figure 5. Cumulative mean pod density (left axes) and cumulative curves of $P$. megakarya and S. singularis (right axes) and rainfall pattern (right axes offset) observed in TFGs in 2003 and 2004.

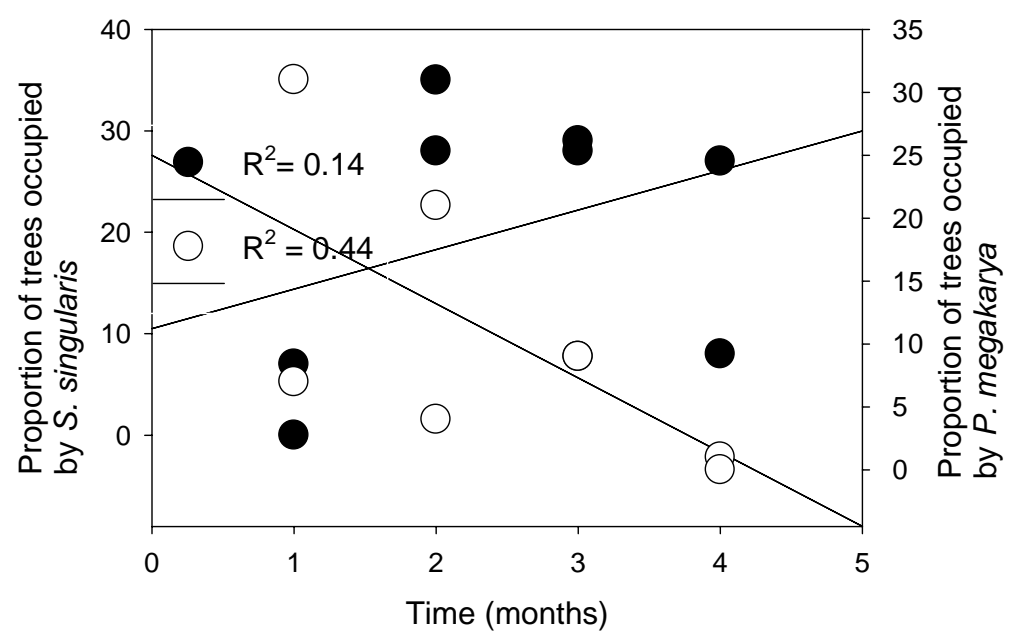

Figure 6. Proportion of sites occupied by P. megakarya (Open circle) and S. singularis (close circle) as a function of time (months) through logistic regression, following a logistic model. All analysis was not significant. Time was computed as mean from three months as followed: 1: April - June; 2: July - September; 3: October - December; and 4: January - March. 

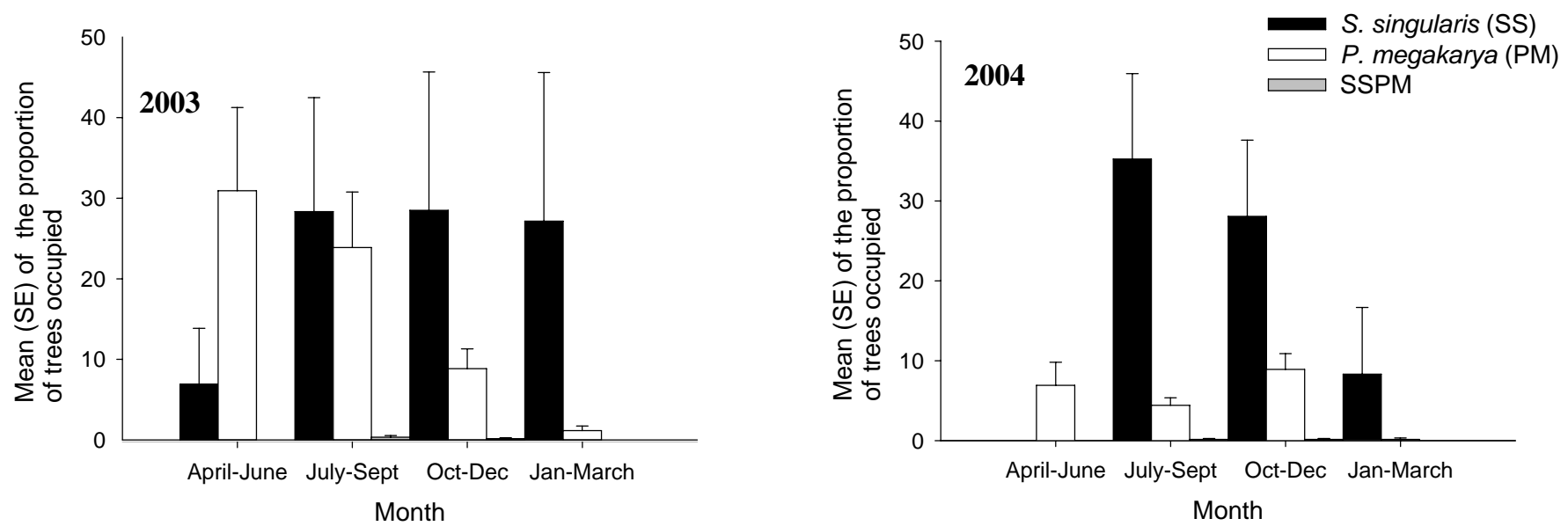

Figure 7. Proportion of trees occupied by S. singularis and by P. megakarya alone or together through time (months) in 2003 and 2004. Data are reported as mean $\pm \mathrm{SE}$.

\section{List of Tables}

Table 1. Cumulative values on the mean pod density, the incidence of black pod disease, population dynamic of mirid bugs, Temperature and rainfall per site for year 2003 and 2004 in TFGs

\begin{tabular}{|c|c|c|c|c|c|}
\hline TFGs & $\begin{array}{c}\text { Mean pod density } \\
\text { (SE) }\end{array}$ & $\begin{array}{l}\text { Mean infected } \\
\text { pod (SE) }\end{array}$ & Mean number of SS & $\begin{array}{c}\text { Temperature } \\
\left({ }^{0} \mathrm{C}\right)\end{array}$ & Rainfall (mm) \\
\hline $\mathrm{EO}$ & $60.00(12.00)$ & $0.49(0.15) b$ & $0.13(0.03) \mathrm{a}$ & $25.87(0.01)$ & $64.08(7.83) b$ \\
\hline EY & $73.00(1.00)$ & $0.03(0.03) \mathrm{a}$ & $0.12(0.05) \mathrm{a}$ & $27.29(0.25)$ & $20.58(3.73) \mathrm{a}$ \\
\hline $\mathrm{HG}$ & $101.00(25.00)$ & $0.13(0.04) \mathrm{a}$ & $0.18(0.07) \mathrm{a}$ & $25.36(0.33)$ & $45.25(8.05) b$ \\
\hline IM & $127.00(30.00)$ & $0.24(0.09) \mathrm{a}$ & $0.30(0.07) \mathrm{a}$ & $26.74(0.34)$ & $43.02(9.14) b$ \\
\hline IY & $144.50(12.50)$ & $0.15(0.06) \mathrm{a}$ & $0.74(0.21) b$ & 26.85(1.19) & $19.91(3.92) a$ \\
\hline$P$ value & * & $* *$ & $* * *$ & $*$ & $* * *$ \\
\hline
\end{tabular}

* Not Significant; ** $\mathrm{P}<0.01 ; * * * \mathrm{P}<0.0001$; Means followed by the same letters are not significantly different. EO - Extensive manage old cocoa forest gardens; EY - Extensive manage young cocoa forest gardens; HG - Home garden cocoa forests; IO - Intensive manage old cocoa forest gardens; IY - Intensive manage young cocoa forest gardens. 


\title{
Impact of ants on black pod disease incidence in cocoa plantations in the humid Rainforest area of Cameroon
}

\author{
${ }^{1,2}$ Hervé D. B. Bisseleua and ${ }^{1}$ Stefan Vidal \\ ${ }^{1}$ Georg-August-University Goettingen, Department of Crop Sciences, Entomological \\ Section, Grisebachstr. 6, 37077 Goettingen, Germany; ${ }^{2}$ Institute of Agricultural Research \\ for Development (IRAD), Nkolbisson Regional Research Centre, BP 2067, Yaoundé, \\ Cameroon.
}

Corresponding author: Hervé D. B. Bisseleua; email: hbissel@gwdg.de

\begin{abstract}
The role of ants in the incidence $P$. megakarya was studied in an experimental exclusion of ants in the presence or absence of the disease on the cocoa in plantations with different management regimes. We provide for the first time provides evidence that ants, although generally regarded as beneficial, do contribute to the incidence of black pod disease given a low diversity of ant species on cacao trees. However, if ant communities become more diverse and niche structure more restricted on these trees, incidence of BPD does decrease. Actually management regime in traditional cocoa forest gardens manipulates ant species richness and evenness at tree level, thus negatively affecting arboreal ant richness. This recent practice will increase black pod incidence and decrease productivity. Given the outstanding impact of the ants, we downgraded the importance of factors such as temperature and relative humidity, which in this scenario did not directly affect BP incidence. Consequently, by keeping a high diversity of ants on their trees, cocoa farmers will be able to maintain a lower incidence of black pod disease. Modifying the functional diversity and composition through modifications in the habitat and land-use change will have large impacts on agroecosystem processes.
\end{abstract}


Keywords: management regime, pathogens, interactions, productivity, stability, ecosystem functioning, species richness, biodiversity, species evenness, functional redundancy

\section{Introduction}

Understanding the relationship between habitat heterogeneity, biodiversity, and functioning of natural ecosystems has been a major focus in several recent studies (Ricketts et al. 2001, Reitsma et al. 2001, Klein et al. 2002a, Siebert, 2002, Tscharntke et al. 2002, Ribas et al. 2003, Armbrecht and Perfecto 2003, Sperber et al. 2004, Hooper et al. 2005, Philppot et al. 2006, Steffan-Dewenter et al. 2007).

A common consensus emerging is that more diversified and species rich systems relate to functional consequences, which in turn will influence ecosystem processes. (Tilman et al. 1997, Chapin et al. 2000, Perfecto et al. 2004). For example, a positive relationship between species diversity and ecosystem stability and productivity has been reported by Tilman et al. 1996, Tilman et al. 1997, Hector et al. 1999, Tilman et al. 2001, and Pfisterer et al. 2004, respectively. On the other hand, habitat disturbance will negatively affect species richness or abundance. This effect has been demonstrated by Moguel and Toledo 1999, Klein et al. 2002b, or Klein et al. 2003, respectively, from agricultural systems or by Mas and Dietsch 2003, Sperber et al. 2004, and Philpott et al. 2006, respectively.

However, little is known about the diversity-stability relationships in agroecosystems. According to the redundancy hypothesis for the relationship between diversity and stability species can be arranged in functional groups, so that ecosystem stability will only suffer when all species are removed from a particular functional group (Johnson et al. 1999).

Traditional land-use systems with crops such as cocoa (Theobroma cacao L.) are characterized by a canopy of shade trees originating either from the pristine forest or deliberately been planted. They harbour a high floral diversity and may serve as surrogates of natural forest for many species (Rice and Greenberg 2000, Klein et al. 2002b). 
The introduction of intensive management practices in traditional cocoa forest gardens (TFGs) in Central and South America has been identified as one of the most important factors in the loss of diversity of predators such as ants (Majer 1994, Philpott and Armbrecht 2006).

Ants provide ecosystem services by preying on pests in agroecosystems (Way and Khoo 1992, Vandermeer et al. 2002) or by restricting interactions between plants and disease vectors (Khoo and Ho 1992). Their communities are often structured by interspecific interactions and are of mosaic distribution in cocoa plantations (Majer 1994, Jackson 1984). However, so far no studies have focused on arboreal ant species communities in cacao plantations.

The role and the impact of ant species diversity as potential vectors of black pod disease have been poorly studied in detail. For example, Evans (1973), Taylor and Griffin (1981), Babacauh (1882) focused on dominant ant species such as the Crematogaster spp and Oecophylla longinoda with less attention on diversity in relation to black pod incidence.

Black pod disease caused by P. megakarya Brasier and Griffin (Nyasse 1992) is one of the most important limiting factors in cocoa production in southern Cameroon. Losses have been reported as high as $100 \%$ depending on location, cultivars (Nyasse et al. 2007) and present environmental conditions (Efombagn et al. 2004). A combination of fungicide treatments, cultural practices such as pod removal (Opoku et al. 2000, Soberanis et al. 1999, Ndoumbè et al. 2004), selection of less susceptible cultivars (Nyasse et al. 2003) or the use of biological control agent such as Trichoderma asperellum have been applied to control black pod disease.

The present study aims at evaluating the interactions between ant community structure and diversity and black pod incidence with regard to local variation and land-use management such as TFGs. We hypothesized that (i) Land-use intensification in traditional forest garden with cocoa negatively affects diversity of ants and reduce yield (ii) at least some ant species might act as vectors of Black pod disease (BPD) caused by P. megakarya (iii) manipulating ants diversity will influence BPD incidence. 


\section{Material and method}

\section{Study sites and habitat classification}

See Chapter 1 for details.

\section{Sampling of ants}

Arboreal ant activities on the cocoa tree surfaces were sampled between 0900 and $1300 \mathrm{~h}$ using a "beat and collect" method. Thirty randomly selected pod-bearing trees in each site per TFG were struck five times at the base of the stem and additionally five times at the base of the canopy such that ants fell into a suspended white cloth $(2 \times 2 \mathrm{~m})$ placed beneath the tree canopy. The size of the cloth assured that a high percentage of the ants that fell from the tree were captured. All ants on the cloth were collected using an aspirator and identified to species level in the lab. Each tree was subsequently monitored by six co-workers (two trees per co-worker) and ants moving from the ground to the canopy and from the canopy back to the ground were monitored on $10 \mathrm{~cm}$ white stripes, fixed on the trunks at $150 \mathrm{~cm}$ height. Ant specimens passing these stripes were collected using forceps and later identified to species level. Care was taken to select trees which were at least $15 \mathrm{~m}$ apart in order to assure independence of samples.

\section{Experimental design}

At the governmental cocoa research station, Nkoemvone, we selected two plots with cocoa cultivars SNK 16 and two with cocoa cultivars T79/467. These cultivars were selected for their susceptibility to $P$. megakarya infections. Land-use intensity and management measures were similar to that observed in the intensive old systems of TFGs. Fourty pod-bearing trees with ants were marked per plot to determine the role of ants with regard to black pods incidence. Ants were collected on each tree using the "beat and collect" method, as described previously, for identification. Trees were pruned to avoid overlapping branches and all pods between 0 and $50 \mathrm{~cm}$ from the ground were removed. Each plot was divided into two subplots of twenty trees. Trees were later divided randomly per subplot into four blocks of five trees, respectively and treated as follows: Block 1: First two pods at $50 \mathrm{~cm}$ from the ground per tree were inoculated (In) 
with spores of a virulent strain of $P$. megakarya and ants allowed to freely forage on the tree (In with ants); Block 2: First two pods at $50 \mathrm{~cm}$ from the ground per tree were inoculated with spores of a virulent strain of $P$. megakarya and trees free from ants (In without ants). Block 3: Pods receiving no inoculation (NIn) and ants allowed on trees (NIn with ants) and; Block 4: Pods receiving no inoculation and ants free from trees (NIn without ants). In block 2 and 4 of each subplot, ants and insects were removed from the trees with a knockdown insecticide and provided with a tangle foot barrier at the lower part of the stem to prevent insects from climbing up again. Daily observations were first based on the success of inoculation and later on the spreading rate of the disease.

Additionally two blocks of 15 pod bearing trees with ants were selected in each site per TFG (Block 1: TFGs with ants and Block 2: TFG without ants) their pods marked and numbered. Only trees with no pods between 0 and $50 \mathrm{~cm}$ from the ground were selected. Trees were pruned to avoid overlapping branches or leaves having contact with nearby trees. Insects and ants on trees in block 2 were removed with a knockdown insecticide and provided with a tangle foot barrier at the lower part of the stem to prevent insects from climbing up again. Trees were observed bi-weekly for the spreading rate of the disease. Infections originating from rodent bites were not considered during field observations. The total number of pods of all sizes seen on each tree was counted weekly in Nkoemvone and bi-weekly in TFGs. To quantify new infections by P. megakarya on cocoa trees we divided each tree into two portions: the trunk below $150 \mathrm{~cm}$ and the branches above $150 \mathrm{~cm}$.

\section{Preparation of the inoculum and field inoculation}

The "Boyo strain" of P. megakarya used for the preparation of the inoculum was provided by the Laboratory of Phytopathology of the "Institut de la Recherche Agricole pour le Développement (IRAD, Yaoundé)". The strain was transferred to a standard V8 growth medium in $90 \mathrm{~mm}$ diameter Petri dishes for growth. After ten days, the white mycelium was recovered and the virulence of the fungus was proved by inoculating a healthy cocoa pod, wounded on its median part using a $10 \mathrm{~mm}$ diameter disc punch, with a piece of PDA (Potato Dextrose Agar) cut out from the V8 medium preparation. Thereafter, the wound was covered with wet cotton soaked with distilled water. The inoculated pods were incubated in darkness at ambient temperature and saturated 
moisture environment. A BPD infection was regarded successful when a brown spot of more or less circular form, spreading from the point of inoculation, was observed. A few days later, the fungus was isolated from the infected pod by collecting a piece of tissue below the brown spot and transferred to an artificial medium for mass production.

Seven days old cultures, from mass production, were used for artificial inoculation of pods in the field. On each inoculated tree, the first two pods at $50 \mathrm{~cm}$ from the ground were selected and a circular wound of approximately $5 \mathrm{~mm}$ depth was perforated on its median part using a $10 \mathrm{~mm}$ diameter disc punch. The wound was covered with a piece of PDA (containing the fungus) collected from the above preparation and covered with wet cotton soaked with distilled water.

\section{Statistical analysis}

The data were analyzed using Systat 11 (SPSS Inc 2000). When necessary, logarithm or square root-transformed variables were used to meet normal distributions.

We analyzed black pod incidence data in the different treatments between systems by comparing the number of infected pods per TFG and site to assess the role of ants. A twofactor (sites, habitats) unbalanced nested design was used for an ANOVA on the dependent variables (number of infected pod). The unbalanced design resulted from different numbers of sites for each TFG type; however, there were the same number of observations within each site. We calculated the productivity factor from weekly counts of the number of pods of all sizes that were present on each tree. This was done by totaling the highest number of pods observed on each tree in each treatment and dividing it by the number of trees in the category. Black pod incidence in relation to productivity was calculated by dividing the number of black pod per tree by the mean maximum numbers of pods per tree. Between treatments differences in TFG were analyzed using a t-test. Occurrence of ant species on trees and black pod incidence was compared using a Kolmogorov-Smirnov Test. When the model indicated statistically significant differences with regard to TFGs and sites, a Kruskal-Wallis nonparametric test was used to test for significant differences. Estimates of total diversity $(S, H, E$ and $d)$ were compared statistically using ANOVA between TFGs with habitat as a main factor. One wayanalyses of covariance (ANCOVA) was used to compare treatments using number of infected pods and ant diversity indices as the dependent variable and temperature, relative 
humidity, canopy and herbaceous cover separately as the covariates. The objective was to test for differences between treatments and for correlation between black pod incidence and diversity; and abiotic factors. ANOVA was also performed on the foraging sites of dominant ant species associated with BP incidence and differences were separated using Duncan multiple range test when F-values were significant. Finally, a multiple regression analysis was performed to assess the impact of $\alpha$-diversity of arboreal ants on black pods incidence, using the number of infected pods as the response variable.

\section{Results}

\section{Incidence of black pod diseases}

Two days after inoculation, all inoculated pods exhibited initial symptoms of black pod disease (BPD), typically showing a brown spot of more or less circular form spreading out from the point of inoculation. Therefore, no pods had to be re-inoculated. There was a marked variation in BP incidence in the presence or absence of ants on trees with the mean number of infected pods significantly $\left(\mathrm{F}_{1,29}=47.60, \mathrm{p}<0.001\right)$ higher on trees with ants as compared to trees without ants $(t=6.90)$. The lowest incidence of BPD was recorded on non-inoculated trees without ants $\left(\mathrm{F}_{3,59}=7.04, \mathrm{p}<0.001\right)$ (Figure 1). When inoculum was present, ants contributed to the rapid spreading of BPD within trees.

BPD incidence was found more frequently on the trunks (mean \pm SE., 9.4 \pm 2.3 ) of cacao trees as compared to the branches (mean \pm SE., $6.6 \pm 1.3$ ). However the difference was not statistically significant. Climatic conditions did not impact the incidence of BPD on either the trunks or the branches. Although relative humidity in TFGs decreased significantly with increasing temperature $\left(\mathrm{R}^{2}=0.25 ; \mathrm{F}_{4,16}=7.44 ; \mathrm{n}=24 ; \mathrm{P}=0.012\right)$, both parameters were not correlated to the pod infection incidence $\left(\mathrm{R}^{2}=0.19 ; \mathrm{F}_{4,16}=2.62\right.$; $\mathrm{n}=24 ; \mathrm{P}=0.096)$.

\section{Productivity and black pod incidence}

Spacing between trees at Nkoemvone plots was uniform with smaller, however nonsignificant, distances between trees in plots without ants. Mean distance between two consecutive trees varied significantly $\left(\mathrm{F}_{4,255}=24.96, \mathrm{P}<0.001\right)$ in $\mathrm{TFGs}$ and ranged from 
$1.3 \mathrm{~m}$ to $1.6 \mathrm{~m}$ in $\mathrm{HG}$ and $\mathrm{EO}$ respectively. A mean distance of $2 \mathrm{~m}$ was recorded in IY and IM. Productivity, defined as the mean number of pods per tree, was lowest where the trees were most closely planted. Analyses of the productivity factors (Table 1) in Nkoemvone revealed the lowest productivity in NIn - A, with an average of 14.27 (SD \pm 1.13 ) pods per productive tree, followed by $\mathrm{In}-\mathrm{A}$ to $\mathrm{In}+\mathrm{A}$ with an average maximum of $24.33(\mathrm{SD} \pm 2.10)$ pods per productive tree. Similar results were obtained in TFGs (Table 1) with the lowest productivity in EO without ants with an average of $5.20(\mathrm{SD} \pm 0.90)$ pods per productive tree, followed by HG without ants, IY without ants, EY without ants to IY with ants with an average of $10.88(\mathrm{SD} \pm 0.59)$ pods per productive tree.

The productivity factor was correlated with BP incidence (Table 1). The higher the number of pods per tree, the more likely that ants or their tents could be found on these trees. The presence of ants on trees significantly increased the incidence of BP and significantly $\left(\mathrm{F}_{3,59}=5.85, \mathrm{p}<0.01 ; \mathrm{F}=4.70, \mathrm{df}=28, \mathrm{t}=4.67, \mathrm{P}<0.001\right)$ reduced productivity (Table 1).

\section{Ant species and black pod incidence}

A total of 9239 specimens accounting for 30 species of arboreal ants were collected with Crematogaster sp.1 (52.7\%), O. longinoda (18.7\%), Camponotus sp.1 (5.3\%) and C. brutus (5.1\%), respectively, being the most abundant. We found significant differences between TFGs for ant species richness $\left(\mathrm{F}_{4,16}=3.55, \mathrm{P}<0.05\right)$ with the highest richness in EO and the lowest in IM. Regression analysis of the single habitat parameters with landuse intensity revealed that species richness $\left(\mathrm{F}_{4,16}=4.89 ; \mathrm{R}^{2}=0.25 \mathrm{n}=17, \mathrm{P}<0.001\right)$ decreased with increasing land-use intensity. Black pod incidence was higher in trees where ant species were found foraging alone (Figure 2). However, the results from Figure 2 also indicate that when more than one ant species were foraging on the same tree, the incidence of BPD was reduced. We also observed that Crematogaster sp. 1, due to its abundance $(52.7 \%$ of total individual species) and wide distribution in TFGs was the most common ant associated with the incidence of BPD (Kolmogorov-Smirnov Test, $\mathrm{P}<0.05)$. 


\section{Foraging sites of ant species}

Foraging sites of dominant ant species associated with BPD incidence were significantly different $\left(\mathrm{R}^{2}=0.56 ; \mathrm{F}=6.36 ; \mathrm{n}=3 ; \mathrm{P}=0.005\right)$ between ant species and location within cacao trees (Figure 3). We recorded a strong negative association between $O$. longinoda and C. brutus when analyzing association of these species using only trees harbouring all 4 species (not taking into account their abundance). Crematogaster sp.2 and O. longinoda were consistently found in the upper parts of the trees (branches), if nesting alone or together with other ant species. However, Crematogaster sp.1 was always found in the upper part of the trees (above $150 \mathrm{~cm}$ ) whenever C. brutus was occupying the lower part of the tree (below $150 \mathrm{~cm}$ ). When nesting together with Crematogaster sp.2 or $O$. longinoda, Crematogaster sp.1 was always found below $150 \mathrm{~cm}$. C. brutus was generally found on the mid-trunk (below $100 \mathrm{~cm}$ ), usually tending mealybugs or coccids. However, when dominant ant species were absent, C. brutus was found to colonize also the cocoa tree canopies ( $4 \%$ of cocoa trees sampled).

\section{Diversity and black pod incidence in TFG}

Because management regime significantly affected arboreal ants, we tested the impact of arboreal ants on the incidence of black pods using diversity indices. Ant species richness and evenness significantly differed $\left(\mathrm{F}_{4,16}=26.81, \mathrm{p}<0.01\right)$ between TFGs. Black pod incidence decreased significantly $(\mathrm{P}<0.01)$ with increasing species richness of arboreal ants and increased significantly $(\mathrm{P}<0.01)$ with increasing evenness (Figure 4), when arboreal ant species richness and evenness were used as explanatory variables

\section{Discussion}

\section{Incidence of black pod diseases}

We were able to show that ants, although generally regarded as beneficial in cocoa plantations (Way and Khoo 1992, Philpott and Armbrecht 2006) do increase the incidence of black pod disease provided a low diversity of ant species is present on the cacao trees. However, if ant communities became more diverse and the habitats occupied by the ants more restricted on these trees, the incidence of BPD decreased. Ant activity 
and tents building at the lower part (trunk) of the cocoa tree was responsible for the high incidence of black pod in this section compare to the upper tree parts. When studying spatial distribution of pods on the trees, Efombagn et al. (2004) observed that the pods on the trunk were more susceptible to BPD infections than those on the branches. The incidence of BPD infections on pods below $150 \mathrm{~cm}$ might have been fostered through soil splash. Though, soil from ant tents were collected and failed to initiate any infection when tested in the laboratory on detached cocoa pods (personal observation). This suggests that ant tents might not be such an important source for BPD infections because they are generally made of dry plant particles or arthropod debris. Nevertheless, studies by Evans (1973), Taylor and Griffin (1981) in Nigeria; Babacauh (1982) in Côte d'Ivoire incriminated soil and plant debris from ant tents to vector BPD.

Seasonal changes in temperature and rainfall have an influence on ants that are generally more abundant and active in the wet season (Gove and Majer 2006, Philpott et al. 2006). We found no significant relationship between the incidence of BPD and temperature or relative humidity in the TFGs sampled. Previous correlations of environmental factors and incidence of BPD led to conflicting results in different cocoa growing regions (Wood 1974, Maddison and Griffin, 1977). These authors attributed the lack of correlations to differences in weather patterns, climatic conditions or pathogenic strains involved. Nonetheless, we suggest that environmental factors by directly influencing the abundance and activities of ants indirectly affect the incidence of black pod disease in cocoa plantations. Hence the contradictory results obtained from cultural practices through weekly removal of infected pods in cocoa plantations in Peru (Soberanis et al. 1999), Ghana (Opoku et al. 2000) and Cameroon (Ndoumbè et al. 2004).

\section{Productivity and black pod incidence}

We found that with increasing numbers of pods on a tree, the more likely that ant or their tents could be found on these trees, which in turn resulted in a higher incidence of BPD. A positive relationship observed between environmental factors, incidence of black pod disease and potential yield by Nyasse et al. (2003) advocate a positive relationship between ants and P. megakarya. Jackson (1984) reported that ant activity or tent building on cacao trees is a consequence of the presence of Homoptera, which attract ants because of their sugar-containing exudates. According to Taylor and Griffin (1981), ants construct 
the tents to protect the Homoptera from adversities, such as rainfall and predators. The Homoptera are usually found feeding on young plant tissue; the most abundant plant tissue on cocoa trees mainly on the lower parts of the tree is produced by the flower cushions. This includes flowers from bud to maturity, and, after flower set, pods throughout their growth. As pods mature, they cease to be a food source for aphids and therefore, the attraction of ants is limited to coccids. Seasonal activity of ants is synchronized with seasonal presence of its food. Ants and Homoptera interactions at flower cushions or at the peduncle make this site a primary source of infection for BPD (Babacauh 1982, Ndoumbè et al. 2004). We observed that, among the species of Homoptera that attracted ants to construct tents, Toxoptera aurantii (Boy), was the most abundant specifically at the early season. Aphids are becoming an important pest in cocoa plantation in southern Cameroon and their overall role on cocoa are poorly studied.

\section{Ant species and black pod incidence}

We unambiguously demonstrated that ant species differ in their role as vectors of BPD. Our study showed that the more ant species on a tree, the lower the incidence of black pod disease suggesting that niche restriction through selective increase richness of arboreal ants will negatively affect the incidence of black pod in cocoa plantations. $C$. brutus and $O$. longinoda by mutually coexisting with the Crematogaster's species may be keystone species or "functional group" (De Leo and Levin 1997) in reducing the incidence of black pod disease in cocoa plantations. However, Crematogaster sp. 1 can be of major importance as a vector of BPD because it is an abundant and active species in the studied area.

\section{Foraging sites of ant species}

Traditional cocoa forest gardens are heterogeneous environments. Tree productivity varied significantly according to the spacing distribution of trees and, consequently the amount of ant tent building activity. Resource defense may not be economic if the density of other species trying to get access to the resource is high. Abundant ant species as the case in cocoa plantations have mutually exclusive distributions generated by competition, thus forming a "mosaic" of territories in the cocoa trees (Majer 1976). Majer (1994) suggested that a dominant ant species are numerically superior, where it occurs, have 
large populations, and excludes other dominants. They determine the distribution of less abundant ant species and possibly other arthropods in cocoa plantations (Majer 1976, Chapin 2000). By excluding what was called non beneficial ants (i.e. non predatory ants) in cocoa plantations cocoa farmers contributed in the establishment of dominants species (Crematogaster spp. and O. longinoda). We have observed that the distribution of niche and niche overlap of one ant species is affected by the presence or absence of another portraying the importance of each ant species in this agroecosystem. Thus, the functional redundancy (Gitay et al. 1996) of species within cocoa plantation should not be interpreted as a justification for their elimination. The effect of removal of one species cannot be predicted within an agroecosystem and in the absence of other species and loss of interactions; any dominant species has become a potential vector of black pod disease. Changes in ant community composition has exposed TFG to vulnerability to invasion and phenomenon such as ants being regarded as pests by cocoa farmers in southern Cameroon (Chapter 2) could be a consequence of such intervention. It is therefore possible to manipulate the distribution of the ants by influencing the nature of the habitats so as to balance species density.

\section{Diversity and black pod incidence in TFG}

These results suggest that changes in land-use management from extensive to intensive, as actually practiced in cocoa plantations in southern Cameroon, may results in a significant decrease of diversity of arboreal ants. Our experiments demonstrate the importance of ant diversity and evenness as determinants of productivity. Although the impact of species richness in species-rich, natural ecosystems is poorly understood, we hypothesize that stability and productivity of cocoa plantations with low ant species diversity may be influenced by two factors; increasing species diversity or reducing environmental heterogeneity. Increasing species richness will have a positive effect on productivity (Tilman et al.1996; Hector et al. 1999). All the same, Species evenness should deserve further attention because it is more affected by anthropogenic disturbances than richness. However, diversification with the aim of enhancing stability and productivity of traditional cocoa forest gardens should therefore seek a balance in increment of species richness and evenness. 


\section{Conclusion}

This study for the first time provides evidence that ants, although generally regarded as beneficial, do contribute to the incidence of black pod disease given a low diversity of ant species on cacao trees. However, if ant communities become more diverse and niche structure more restricted on these trees, incidence of BPD does decrease. Actually management regime in traditional cocoa forest gardens manipulates ant species richness and evenness at tree level, thus negatively affecting arboreal ant richness. This recent practice will increase black pod incidence and decrease productivity. Given the outstanding impact of the ants, we downgraded the importance of factors such as temperature and relative humidity, which in this scenario did not directly affect BP incidence. Consequently, by keeping a high diversity of ants on their trees, cocoa farmers will be able to maintain a lower incidence of black pod disease. Modifying the functional diversity and composition through modifications in the habitat and land-use change will have large impacts on agroecosystem processes. Our results provide a different insight in the management of cocoa agroforestry systems. Our results may also contribute to the understanding of ants and other diseases (such as the recent incidence of Oncobasidium theobromae Talbot \& Keane (1971) (dieback) of cocoa.

\section{Acknowledgments}

Financial assistance was provided by the University of Goettingen (IPAG "International PhD Programme in Agricultural Sciences in Goettingen"). We thank CIRAD, Cameroon for logistic support during field works; the staff of the Laboratory of Entomology at the "Institut de la Recherche Agricole pour le Développement" (IRAD) in Nkolbisson, Cameroon: M. Djalla, AD. Missoup, M. Mbenoum, V. Ondoua, J. Nzomo, JC. Mongo, N. Essomo, C. Ngoum Esse and V. Koumpia and smallholder cocoa farmers for help in the field. 


\section{References}

Armbrecht, I. and Perfecto, I. (2003) Litter-twig dwelling ant species richness and predation potential within a forest fragment and neighboring coffe plantations of contrasting habitat quality in Mexico. Agric. Ecosys. and Envir. 97, 107 - 115.

Babacauh, K.D. (1982) Rôle des communautés d'insectes et de l'eau dans la dissémination de Phytophthora palmivora (Butl.) Bult. Emend. Bras. Et Griff. Dans les cacaoyères de la Côte d'Ivoire. Café Cacao Thé, 1, 31-36.

Chapin, F.S. III, Zavaleta, E.S., Eviner, V.T., Naylor, R.L., Vitousek, P.M., Reynolds, H.L., Hooper, D.U., Lavorel, S., Sala, O.E., Hobbie, S.E., Mack, M.C. \& Diaz, S. (2000) Consequences of changing biodiversity. Nature, 405, 234-242.

Efombagn, M.I.B., Marelli, J.P., Ducamp, M., Cilas, C., Nyasse, S., \& Vefonge, D. (2004) Effect of fruiting traits on the field resistance of cocoa (Theobroma cacao L.) clones to Phytophthora megakarya. J. of Phytopath. 152, 557-562.

Evans, H.C. (1973) Invertebrate vectors of Phytophthora palmivora, causing black pod disease of cocoa in Ghana. Ann. of Appl. Biol. 75, 331-345.

Gitay, H., Wilson, J.B., \& Lee W.G. (1996) Species redundancy: a redundant concept? J. of Ecol. 84, 121-124.

Hector A., Schmid, B., Beierkuhnlein, C., Caldeira, C., Diemer, M., Dimitrakopoulos, P.G., Finn, J.A., Freitas, H., Giller, P.S., Good. J., Harris, R., Högberg, P., Huss-Danell, K., Joshi, J., Jumpponen, A., Körner, C., Leadley, P.W., Loreau, M., Minns, A., Mulder, C.P., O'Donovan, G., Otway, S.J., Pereira, J.S., Prinz, A., Read, D.J., Scherer-Lorenzen, M., Schulze, E-D., Siamantziouras, A.D., Spehn, E.M., Terry, A.C., Troumbis, A.Y., Woodward, F.I., Yachi, S. \& Lawton J. (1999) Plant diversity and productivity in European grasslands. Science, 286, 1123-1127. 
Hooper D., Chapin F.S.III., Ewel J., Hector A., Inchausti P., Lavorel S., Lawton J., Lodge D., Loreau M., Naeem S., Schmid B., Setälä H., Symstad A., Vandermeer J. and Wardle D. (2005) Effects of biodiversity on ecosystem functioning: a consensus of current knowledge. Ecolo. Monographs, 75, 3 - 35.

Jackon, D.A. (1984) Ant distribution patterns in a Cameroonian cocoa plantation: investigation of the ant mosaic hypothesis. Oecologia, 62, 318-324.

Johnson, K.H., Vogt, K.A., Clark, H.J., Schmitz, O.J. \& Vogt, D.J. (1996) Biodiversity and the productivity and stability of ecosystems. Trends in ecol. and evol. 11, 372-377.

Kho, B. \& Ho, C.T. (1992) The influence of Dolichoderus thoracicus (Hymenoptera: Formicidae) on losses due to Helopeltis thievora (Heteroptera: miridae), Black pod disease, and mammalian pests in cocoa in Malaysia. Bull. of Entomol. Res. 82, 485 491.

Klein A., Steffan-Dewenter, I., \& Tscharntke, T. (2003) Fruit set of highland coffee increases with the diversity of pollinating bees. Proceedings of the Royal Society London, 270, 955-961.

Klein A., Steffan-Dewenter, I., Buchori, D., \& Tscharntke, T. (2002a) Effects of land-use intensity in tropical agroforstry systems on coffee flower-visiting and trap-nesting bees and wasps. Conserv. Biol. 16, 1003-1014.

Klein A.M., Steffan-Dewenter, I., \& Tscharntke T. (2002b) Predator-prey ratios on cocoa along a land-use gradient in Indonesia. Biodiver. and Conserv. 11, 683-693.

Maddison, A.C., \& Griffin, M.J. (1977) Results of some preliminary work on the epidemiology of two types of Phytophthora attacking cocoa in West Africa. 5th International Cocoa Research Conference, Ibadan, Nigeria, pp. 423-428. 
Majer, J.D. (1976) The influence of ants and ant manipulation on the cocoa farm fauna. J. of Appl. Ecol. 13, 157-175.

Majer, J.D. (1994) Arboreal ant community patterns in Brazilian cocoa farms. Biotropica, $26,73-83$.

Mas, H.A., \& Dietsch, T. (2003) An index of management intensity for coffee agroecosystems to evaluate butterfly species richness. Ecolo. Applic. 13, 1491-1501.

Moguel P., \& Toledo VM. (1999) Biodiversity conservations in traditional coffee systems of Mexico. Conserv. Biol. 13, 11-22.

Nboumbè-Nkeng, M., Cilas, C., Nyemb, E., Nyasse, S., Bieysse, D., Flori, A., \& Sache, I. (2004) Impact of removing diseased pods on cocoa black pod caused by Phytophthora megakarya and on cocoa production in Cameroon. Crop Protec. 23, 415-424.

Nyasse, S. (1992) Structure d'une population de Phytophthora sp. Des cacaoyères camerounaises atteintes de pourriture brune. DRU Sciences agronomiques, Institut National Polytechnique de Toulouse.

Nyasse, S., Efombagn, M.I.B., \& Eskes, B. (2003) Selection fore resistance to black pod disease and yield gains prediction by use of selected cocoa varieties in Cameroon. Plant Genetic Resources, 12, 157-160.

Nyasse, S., Efombagn, M.I.B., Kébé, B.I., Tahi, M., Despréaux, D., \& Cilas, C. (2007) Integrated management of Phytophthora diseases on cocoa (Theobroma cacao L): Impact of plant breeding on pod rot incidence. Crop Protec. 26, 40 - 45.

Opoku, I.Y., Appiah, A.A., Akrofi, A.Y., \& Owosu, G.K. (2000) Phytophthora megakarya: A potential threat to the cocoa industry in Ghana. Ghana J. of Agric. Sci. 33, 237-243. 
Perfecto I., Vandermeer J.H., Bautista G.L., Ibarra Nuñez G., Greenberg R., Bichier P., and Langridge S. (2004) Greater predation in shaded coffee farms: The role of resident neotropical birds. Ecology, 85, $2677-2681$.

Pfisterer, A.B., Joshi, J., Schmid, B., \& Fisher, M. (2004) Rapid decay of diversityproductivity relationship after invasion of experimental plant communities. Basic and Appl. Ecol. 5, 5-14.

Philpott S. and Armbrecht I. (2006) Biodiversity in tropical agroforests and the ecological role of ants and ant diversity in predatory function. Ecolo. Entomol. 31, 369 - 377.

Philpott, S.M., Perfecto, I., \& Vandermeer, J. (2006) Effects of management intensity and season on arboreal ant diversity and abundance in coffee agroecosystems. Biodivers. and Conserv. 15, 139-155.

Reitsma, R., Parrish, J.D. and Mclarney, W. (2001) The role of cacao plantations in maintinaing forest avian diversity in southerneasren Costa Rica. Agrofo. Syst. 53, 185 193.

Ribas, C.R., Schoereder, J.H., Pic, M., \& Soares, S.M. (2003) Tree heterogeneity, resource availability, and larger scale processes regulating arboreal ant species richness. Austral Ecol. 28, 305-314.

Rice, R.A., \& Greenberg R. (2000) Cocoa cultivation and the conservation of biological diversity. Ambio, 29, 167-174.

Ricketts, T.H., Daily, G.C., Erhlich, P.R., \& Fay, J.P. (2001) Countryside biogeography of moths in a fragmented landscape: Biodiversity in native and agricultural habitats. Conserv. Biol. 15, 378-388. 
Siebert, S.F. (2002) From shade-to sun-grown perennial crops in Sulawesi, Indonesia: Implications for biodiversity conservation and soil fertility. Biodiver. and Conserv. 11, 1889-1902.

Soberanis, W., Rios, R., Arévalo, E., Zúñiga, L., Cabezas, O., \& Krauss, U., (1999) Increased frequency of phytosanitary pod removal in cacao (Theobroma cacao) increases yield economically in eastern Peru. Crop Protec. 18, 677-685.

Sperber, CF., Nakayama, K., Valverde, MJ., \& Neves, FS. (2004) Tree species richness and diversity affect parasitoid diversity in cacao agroforestry. Basic and Appl. Ecol. 5, 241-151.

SPSS Inc. (2000) Systat 11 for Windows. SPSS Inc., Chicago.

Steffan-Dewenter I., Kessler M., Barkmann J, Bos M., Buchori D., Erasmi S., Faust H., Gerold G., Glenk K., Gradstein R.S., Guhardja E., Harteveld M., Hertel D., Höhn P., Kappas M., Köhler S., Leuschner C., Maertens M., Marggraf R., Migge-Kleian S., Mogea J., Pitopang R., Schaefer M., Schwarze S., Sporn G.S., Steingrebe A., Tjitrosoedirdjo S.S., Tjitrosoemito S., Twele A., Weber R., Woltmann L., Zeller M., Tscharntke T. (2007) Tradeoffs between income, biodiversity, and ecosystem functioning during tropical rainforest conversion and agroforestry intensification. PNAS 104: 4973 4978

Taylor, B. \& Griffin, M.J. (1981) The role and relative importance of different ant species in the dissemination of black pod disease of cocoa. In: P.H. Gregory \& A. C. Maddison (Eds), Epidemiology of Phytophthora on Cocoa in Nigeria (pp. 114-131), Wallingford, UK: CAB.

Tilman D., Knops J., Wedin D., Reich P., Ritchie M., \& Siemann E. (1997) The influence of functional diversity and composition on ecosystem processes. Science, 277, 13001302. 
Tilman D., Wedin D., \& Knops J. (1996) Productivity and sustainability influenced by biodiversity in grassland ecosystems. Nature, 379, 718-720.

Tilman, D. (1996) Biodiversity: population versus ecosystem stability. Ecology, 77, 35063.

Tilman, D., Reich, P.B., Knops, J., Wedin, D., Mielke, T., \& Lehman, C. (2001) Diversity and productivity in a long-term grass-land experiment. Science, 294, 843-845.

Tscharntke, T., Steffan-Dewenter, I., Kruess, A., \& Thies, C. (2002) Characteristics of insect populations on habitat fragments: A mini review. Ecolo. Res. 17, 229-239.

Vandermeer, J., Perfecto, I., Ibarra-Nunez, G., Philpott, S., \& Garcia-Ballinas, J.A. (2002) Ants (Azteca sp) as potential biological control agents in organic shade coffee production in Southern Chiapas, Mexico: complication of indirect effects. Agrofo. Syst. $56,271-276$.

Way, M.J., \& Khoo, K.C. (1992) Role of ant in pest-management. Ann. Rev. of Entomol. $37,1335-1355$.

Wood G.A.R. (1974) Black pod and meteorological factors. In: P.H. Gregory PH. (eds.), Phytophthora Diseases of Cocoa, (pp. 153-159). London, UK: Longman. 


\section{List of Figures}
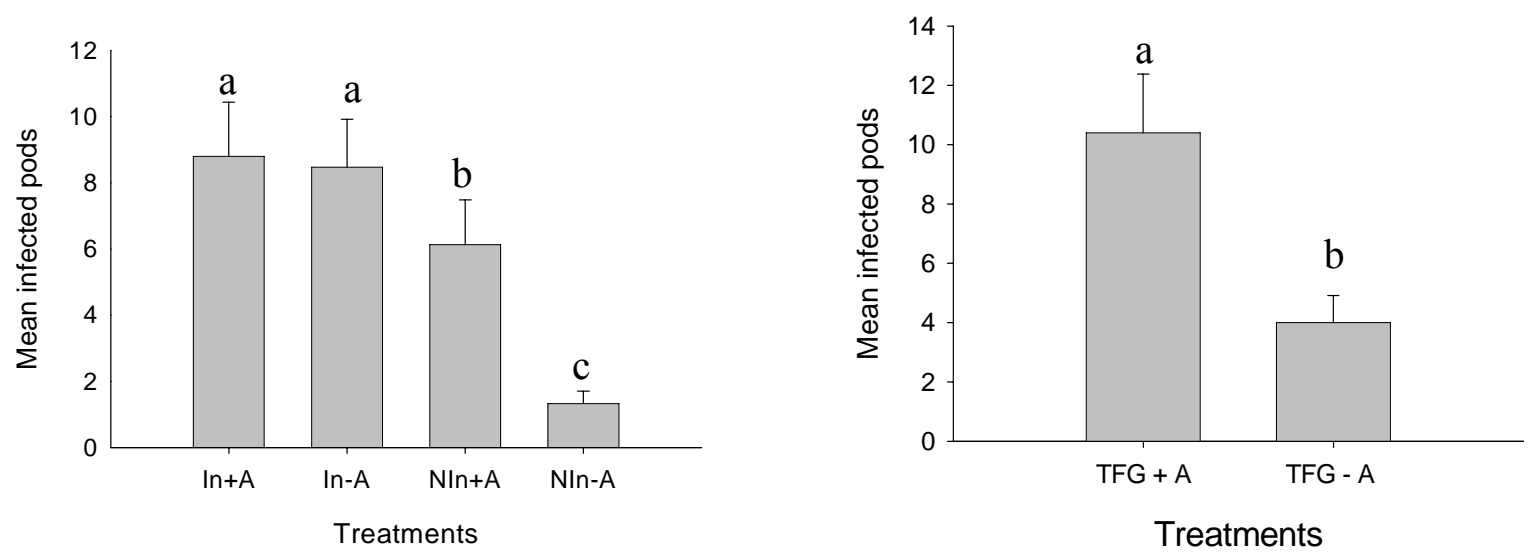

* same letters above graphs are not significantly different

Figure 1. Mean number of infected pods (Black pod disease, P. megakarya) in TFGs in the presence or absence of ants. (In+A: Inoculated cocoa tree with ants; In-A: Inoculated cocoa tree without ants; NIn+A: Non-inoculated tree with ants; NIn-A: Non-inoculated tree without ants; TFG+A: Cocoa tree in Traditional Forest Garden with ants; TFG-A: Cocoa tree in Traditional Forest Garden without ants)

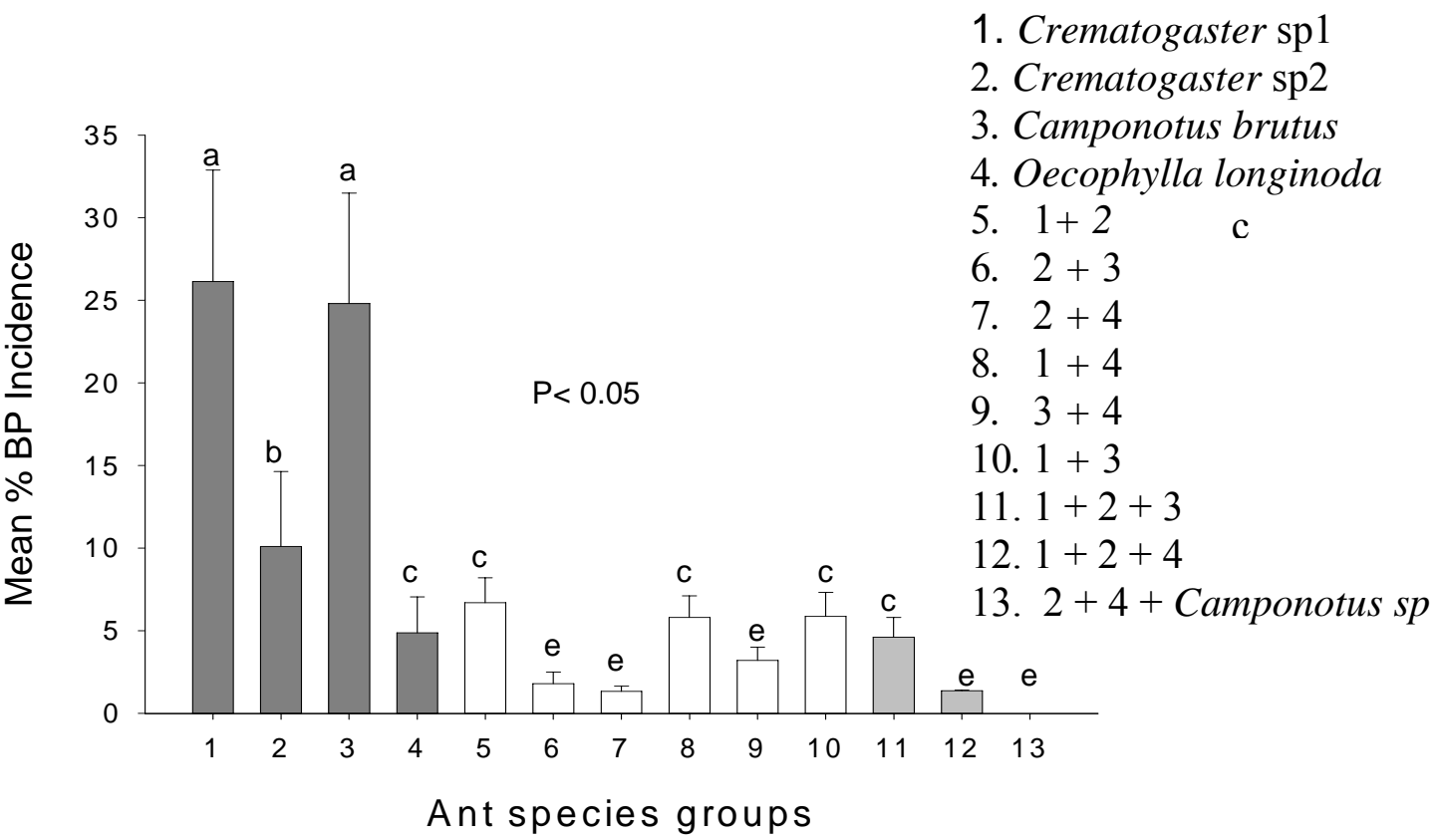

* same letters above graphs are not significantly different

Figure 2. Relationship between ant species, ant species associations and incidence of black pod diseases 


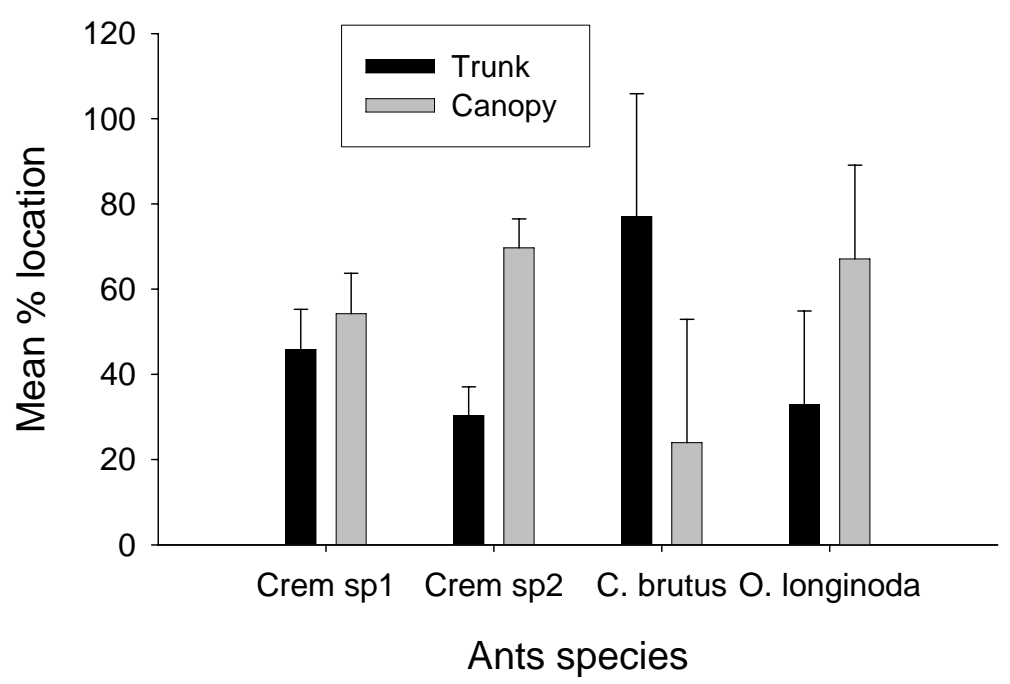

Figure 3. Foraging sites of key ant species when found alone on cocoa trees in TFG (Crem sp: Crematogaster sp)
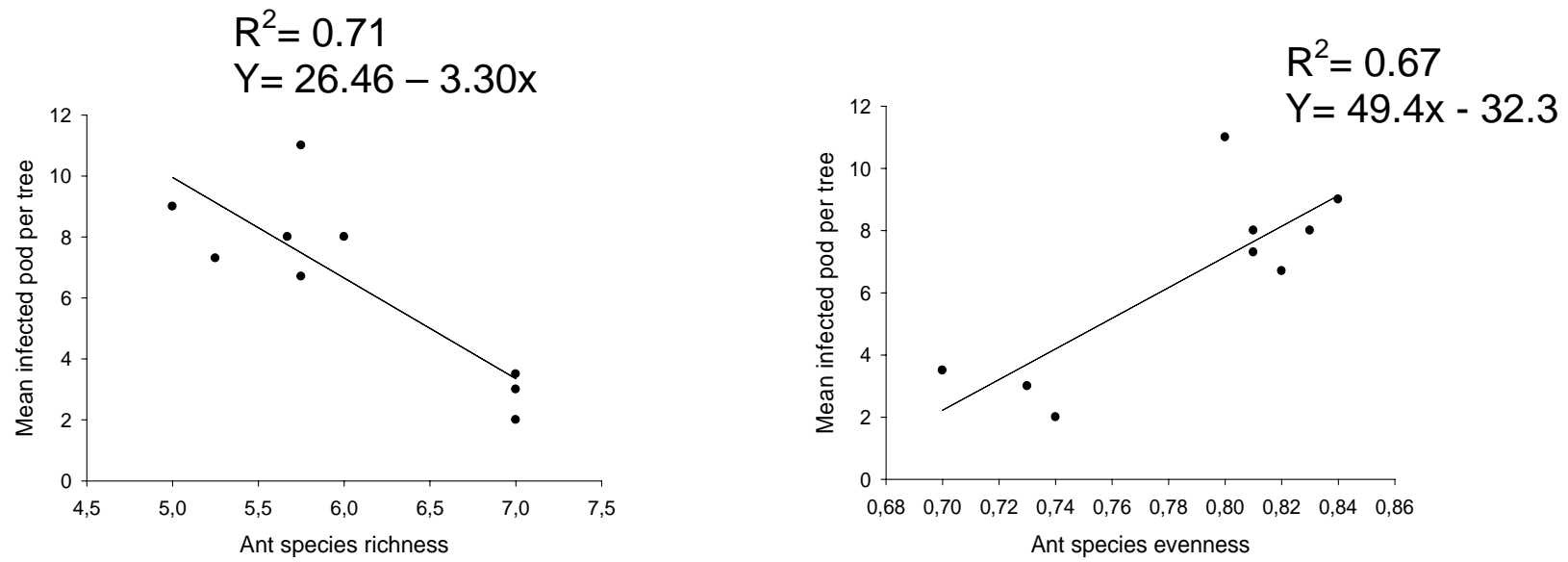

Figure 4. Influence of ant species richness $\left(\mathrm{F}_{1,8}=17.26 ; \mathrm{P}=0.004\right)$ and Evenness $\left(\mathrm{F}_{1,8}\right.$ $=13.93 ; \mathrm{P}=0.007)$ on black pods incidence 


\section{List of Tables}

Table 1. Productivity factors (PF) and comparison of productivity factors and black pod incidence

PF

Type of TFG

(mean pods/tree)

On station

In with ants

$24.33 \pm 2.10 \mathrm{a}$

$6.58 \pm 0.31 \mathrm{a}$

In without ants

$20.07 \pm 3.00 \mathrm{~b}$

$5.22 \pm 0.23 \mathrm{a}$

NIn with ants

$21.87 \pm 2.04 \mathrm{a}$

$4.21 \pm 0.24 b$

NIn without ants
Black pods vs PF

\section{On farm}

EO with ants

$8.10 \pm 1.50 b$

$3.46 \pm 0.13 \mathrm{a}$

EO without ants

$5.20 \pm 0.90 \mathrm{a} \quad * * *$

$0.86 \pm 0.03 b$

EY with ants

$9.92 \pm 1.01 \mathrm{a}$

$7.96 \pm 0.15 \mathrm{a}$

EY without ants

$7.18 \pm 0.61 \mathrm{~b} \quad * *$

$3.20 \pm 0.05 b$

HG with ants

$7.89 \pm 1.29 \mathrm{a}$

$5.19 \pm 0.03 \mathrm{a}$

HG without ants

$6.16 \pm 1.51 \mathrm{a} \quad * *$

$2.03 \pm 0.02 b$

$* * *$

IY with ants

$10.88 \pm 0.59 \mathrm{a}$

$2.21 \pm 0.04 \mathrm{a}$

IY without ants

$7.11 \pm 1.51 \mathrm{~b} \quad * * *$

$1.97 \pm 0.02 \mathrm{a}$

$* * * \mathrm{p}<0.01, * * \mathrm{p}<0.05$, same letters within rows are not significantly different;

EO - Extensive manage old cocoa forest gardens; EY - Extensive manage young cocoa forest gardens; HG - Home garden cocoa forests; IM - Intensive manage mature cocoa forest gardens; IY - Intensive manage young cocoa forest gardens 


\title{
Predatory activity of ants in cocoa plantations under different management regimes: The insurance hypothesis
}

\author{
${ }^{1,2}$ Hervé D. B. Bisseleua and ${ }^{1}$ Stefan Vidal \\ ${ }^{1}$ Georg-August-University Goettingen, Department of Crop Sciences, Entomological \\ Section, Grisebachstr. 6, 37077 Goettingen, Germany; ${ }^{2}$ Institute of Agricultural Research \\ for Development (IRAD), Nkolbisson Regional Research Centre, BP 2067, Yaoundé, \\ Cameroon.
}

Corresponding author: Hervé D. B. Bisseleua; email: hbissel@gwdg.de

\begin{abstract}
It is known that biodiversity can enhance diversity and densities of natural enemies of crop pests and diseases, reducing outbreaks. This has been shown for landscape management practices that seek to augment landscape complexity and for intercropping systems that augment biodiversity at a local scale. The idea that species richness increases community-level stability by insuring that some species in a community are tolerant of different environmental fluctuations is defined in ecology as the "insurance hypothesis". This hypothesis was examined theoretically and in microcosm experiments and recently tested empirically in a coffee agroecosystem. In this study we present a test of the insurance hypothesis by examining predation by ants in traditional cocoa forest gardens with different levels of plant diversity. A combination of pieces of tinned tuna oil, honey and cookie crumbs was placed $2 \mathrm{~m}$ high on the tree trunks and $2 \mathrm{~m}$ from the tree on the ground in 17 selected cocoa plantations under different land-use management. Ant species richness was estimated, time to locate baits, time for recruitment and the number of specimen after one hour was recorded. Significant differences were found associated with the different land-use management for all parameters measured with time to locate baits and time for recruitment were significantly shorter in the extensive systems than the intensive ones, indicating that ants can potentially prevent pest outbreaks. Moreover, the effect was significant only for the plantation with a high floristic diversity, providing partial evidence in support of the insurance hypothesis.
\end{abstract}


Keywords: Biodiversity, Biological control, traditional cocoa forest garden, intensification, ecosystem functioning, predator, stability, productivity, species richness, landscape complexity

\section{Introduction}

Diversity in nature is regulated by immigration and emigration processes (Giller et al. 2004, France and Duffy 2006) particularly in fragmented habitats where dispersal maintained diversity (Yachi and Loreau 1999, Loreau et al. 2003). It is known that diverse agroecosystems are less prone to pests and diseases outbreaks because they support a high diversity of natural enemies (Ives et al. 2000, Hooper et al. 2005). Conversely, most agroecosystems are experiencing environmental perturbations or fluctuations through intensification (Elton 1958) contributing to the loss of biodiversity and the weakening of ecosystem function and processes. However, Chapin et al. (2000) observed that species diversity has functional consequences and influence ecosystem processes and services such as the maintenance of soil fertility; nutrient cycling, climate regulation and natural pests and diseases control. Additionally, the type of interactions among species in an agroecosystem and the sensitivity of each species to different types of environmental fluctuations predict the stability of that system.

Predators are generally considered to be important agents of biological control in agroecosystems. They are generally less affected by the loss of habitat area (Tscharntke and Brandl 2004) while their diversity may affect ecosystem function (Perfecto et al. 2004, Philpott and Armbrecht 2006). Increasing predator diversity may have a buffering effect where predator species with high as well as those with low function can be expected to occur because of asynchronicity of their responses, so that a low function in some predator species does not necessarily affect ecosystem productivity resulting in stronger effects on herbivory and plants (i.e. a performance-enhancing effect) with functional redundancy (Naeem and Li 1997; Philpott and Armbrecht 2006) as a consequence. Pertinent to these considerations is the "insurance hypothesis" (Ives et al. 2000; Perfecto et al. 2004; Philpott and Armbrecht 2006), which states that maintaining biodiversity may increase community's stability when environmental conditions changes. 
We studied the role of ants as regulators of herbivores and compare their impact on traditional cocoa forest gardens with different levels of structural and floristic diversity. A considerable number of ecologists have acknowledged the role of cocoa agroforest as a refuge for biodiversity, specifically for ants (Roth et al. 1994; Majer 1994; Greenberg et al. 2000; Siebert 2002; Sperber et al. 2004). Several studies have emphasized on the role of ants in biological control in cocoa plantations (Leston 1973; Majer 1976; Khoo and Chung 1989; Way and Khoo 1989; Way and Khoo 1992; Khoo and Ho 1992, See and Khoo 1996; Davidson et al. 2003; Philpott et al. 2004) or their influence on other predators in agroecosystems (Philpott et al. 2005). Moreover, as cocoa plantations get intensified (with the reduction or elimination of shade trees); it is likely that the response of ant diversity to unpredictable outbreaks may vary. Differences in foraging or behavior within ant species may enhance the responses to herbivory (Duffy 2002; Philpott and Armbrecht 2006) or may boost functionality under the insurance hypothesis. Perfecto et al (2004) has demonstrated that higher bird diversity resulted in increased effectiveness against a pest outbreak in coffee plantation. However, the difficulty to pinpoint the contribution of abundance and richness in pest control suggest the role and density of a particular species responsible for the insurance hypothesis.

To test the hypotheses that more diverse cocoa plantations are less prone to potential pest outbreaks, and that ants are, at least, to some extend responsible for lowering pest numbers, we set up an experiment in traditional cocoa plantations in southern Cameroon under different land-use management ranging from heavy shaded cocoa plantations to relatively low shaded ones. We use a combination of pieces of tinned tuna oil, honey and cookie crumbs as baits to simulate predation, predicting that the time to locate baits, to recruit and remove baits will be shorter when ants are present, and that predation rates would be higher in the more diverse shaded farms than the less diverse farms. In order to relate ecological changes to biological parameters we used forest tree and herb species diversity and canopy cover as an indicator of forest tree loss and intensification. Further, we assessed the functional consequences of maintaining biodiversity in traditional cocoa forest gardens. 


\section{Material and method}

\section{Study region and sites characteristics}

Ecological survey was performed in five cocoa growing regions in the humid forest area of southern Cameroon which includes both evergreen and deciduous rainforest as summarized in Chapter 1.

\section{Plant and ant survey}

Vegetation characteristics were determined within $600 \mathrm{~m}^{2}$ plots $(20 \times 30 \mathrm{~m})$ in each site. All non-cocoa trees $\geq 10 \mathrm{~cm} \mathrm{dbh}$ were individually counted, numbered and identified. Herbs were sampled in 15 quadrates of $2 \times 1 \mathrm{~m}$ in each tree plots per TFG.

Arboreal ants active on the cocoa surface were sampled between 0900 and 1300h using a "beat and collect" method. Thirty randomly selected pod-bearing trees per site were struck five times at the base of the stem and five more times at the base of the canopy such that ants fell into a suspended white cloth $(2 \times 2 \mathrm{~m})$ placed beneath the tree canopy. The size of the cloth assured that a high percentage of the ants that fell were captured. All ants on the cloth were collected using an aspirator and later identified. Five trees other than cocoa with $\mathrm{dbh} \geq 10 \mathrm{~cm}$ were randomly selected per site within each tree plot and a combination of pieces of tinned tuna oil, honey and cookie crumbs $(\sim 4 \mathrm{~g})$ were placed at $2 \mathrm{~m}$ height on the tree trunks (Le Breton et al. 2005). Ant specimens and number of workers that forage on the baits and/or present around baits were collected for further identification in the laboratory. Thereafter, each cocoa tree and forest trees selected above, was subsequently monitored and ants moving from the ground to the canopy and from the canopy back to the ground were monitored on $10 \mathrm{~cm}$ white stripes, manually collected using forceps and later identified. Care was taken to select trees which were at least $15 \mathrm{~m}$ apart in order to assure independence of samples. Baits were also placed on the ground at $2 \mathrm{~m}$ distance from the 5 randomly selected trees with $\mathrm{dbh} \geq 10 \mathrm{~cm}$ to monitor and collect ground foraging ant species. The presence of baits in TFG effectively mimicked a significant increase in the abundance of prey and we hypothesized that there will be an increase in ant foraging activity with increasing vegetational diversity regulating pest outbreaks and also that land-use management in TFGs negatively affects 
prey finding and recruitment by ants and reduces productivity. To assess the functional consequences of maintaining biodiversity in traditional cocoa forest gardens the number of pods damaged by the cocoa pod borers (CPB), the number of CPB holes and CPB larvae, the number of fresh feeding lesions caused by Salbergella singularis Hagh and Heliopeltis sp was recorded on each pod on the 30 randomly selected cocoa trees per site in each TFG. At the same time mirids assemblages were sampled on selected cocoa trees bimonthly "hand height" visual assessment. All parts of each selected tree were carefully inspected from the base up to hand height level. The hand height level is the highest level to which the assessor's fully stretched hand can reach and the number of insects observed was recorded. Data was collected within 6 months period. Monthly counts of insects were done by looking at the nymphal and adult stages especially at pod/stem interface and underneath pod peduncle. Data were transformed to $\sqrt{ }($ count +0.5$)$ before analysis (Steele and Torrie, 1960). GLM using Systat 11 (SPSS Inc, 2000) was used for all analysis involving the above parameters. When the model found statistically significant differences in habitats and sites, Tukey's post-hoc tests were used to determine which were significantly different.

Ant species richness within habitat was used as the response variable. The explanatory variable were plant (tree and herb) density, plant (tree and herb) species richness, habitat and the interaction plant species richness $\mathrm{x}$ habitat, plant density $\mathrm{x}$ habitat. We therefore tested the hypothesis that plant (tree and herb) species richness and plant (tree and herb) density increase ant species richness by using an analysis of covariance (ANCOVA). Due to the likely correlation between tree species richness and tree density, another ANCOVA was performed using tree density, habitat and the interaction between them as explanatory variables and tree species richness as the response variable. Multiple regression analysis was performed to assess the relationship between diversity and yield parameters. 


\section{Results}

\section{Species richness of plants}

Forest tree species and herbaceous species count in the 17 cocoa plantations within the 5 selected traditional cocoa forest gardens (TFG) covering a gradient in canopy cover revealed a significant difference in forest tree and herbaceous species richness respectively with richness, decreasing with increasing intensification. Percent canopy cover and herbaceous cover followed similar trends (Table 1). The lowest percent canopy cover and tree richness was observed in the intensive manage young cocoa forest garden while the lowest herbaceous richness and herbaceous cover was observed in the intensive manage mature cocoa forest garden (Table 1). We also observed that tree species richness was higher in TFG where tree density was also higher $\left(\mathrm{F}=23.94, \mathrm{R}^{2}=0.61, \mathrm{n}=17, \mathrm{P}<\right.$ 0.001) (Figure 1). The interactions between sampling sites and tree density or tree species richness were significant $\left(\mathrm{F}_{4,16}=13.46 ; \mathrm{P}<0.001\right)$ showing a variability response between tree species richness and tree density between habitats.

\section{Species richness of ants}

When looking at arboreal ants, we observed a significant difference in ant species richness and ant densities in the 5 TFGs as with the floristic and structural diversity. We also recorded a significant difference with the ground foraging ant densities between the TFGs. The intensive manage mature cocoa forest garden recorded the lowest richness and EO the highest. There was no significant difference in richness of ants foraging on the ground (Table 2). Regression analysis of the single habitat parameters with land-use intensity showed that species richness of arboreal ants $\left(F=4.89 ; r^{2}=0.25 n=17 ; P<0.05\right)$ and densities of ground foraging ants $\left(\mathrm{F}=8.29 ; \mathrm{r}^{2}=0.35 ; \mathrm{n}=17 ; \mathrm{P}<0.05\right)$ decreased with increasing land-use intensity with the intensive manage mature cocoa forest garden recording the lowest density at baits after $2 \mathrm{~h}$. Arboreal ant species richness responded positively $(\mathrm{P}<0.001)$ to both tree variables in TFG (Figure 1) but did not show any response with herbaceous species richness and herbaceous density. 


\section{Ecosystem functions}

Results on prey finding and removal by arboreal ants in TFGs show a significant increase in time to locate baits $(\mathrm{P}=0.002)$ and time for recruitment $(\mathrm{P}<0.001)$ with land intensification (Table 3). The number of specimen gathered at baits after one $1 \mathrm{~h}$ exposure significantly decreased $(\mathrm{P}<0.001)$ with land intensification with intensively manage systems recording the lowest number of specimen at collecting time. The time for recruitment of arboreal ants decreased significantly $\left(F=7.44 ; r^{2}=0.33 ; n=17, P<0.05\right)$ with arboreal ant richness. No significant difference was found in both the time to locate baits and the time for recruitment of ground foraging ants. However, a significant difference $(\mathrm{P}=0.001)$ was found in the number of ground foraging specimen at baits after $1 \mathrm{~h}$ exposure with the extensive systems recording the highest number of specimen.

To evaluate the functional consequences of changes in species richness and densities in different TFGs we evaluated the rate of herbivory on cocoa pods. We observed that the removal of forest tree species as shade significantly increased the number of pods loss to cocoa pod borers $(\mathrm{CPB})(\mathrm{P}=0.002)$; the number of $\mathrm{CPB}$ holes per cocoa pods $(\mathrm{P}=0.001)$ and the number of CPB larvae per pod $(\mathrm{P}<0.001)$ (Table 4$)$. The feeding activities of two important pests of cocoa namely S. singularis (SS) and Heliopeltis sp known to caused severe damages to cocoa trees, seedlings and pods were evaluated. The number of fresh lesions on pods caused by both pests significantly increased $(\mathrm{P}<0.001)$ with reducing floristic and structural diversity. The intensive systems recorded the highest lesions of both pests. Mean number of SS was significantly different $(\mathrm{P}<0.005)$ between TFG with extensive systems recording the lowest number of SS (Table 4). The number of SS decreased significantly $\left(\mathrm{F}=16.42 ; \mathrm{R}^{2}=0.52 ; \mathrm{n}=17 ; \mathrm{P}=0.0010\right)$ with increasing arboreal ant richness. Regression analysis of plant richness, canopy cover and rate of herbivory showed that higher tree species richness significantly reduced the number of pod loss to $\operatorname{CPB}\left(\mathrm{R}^{2}=0.54 ; \mathrm{P}=0.0007\right)$ and $\mathrm{CPB}$ holes per pods $\left(\mathrm{R}^{2}=0.47 ; \mathrm{P}=0.003\right)$ (Figure 2). Also, a dense canopy cover significantly reduced the number of pod loss to $\mathrm{CPB}\left(\mathrm{R}^{2}=0.28\right.$; $\mathrm{P}<0.05$ ) (Figure 3 ) and $\mathrm{CPB}$ holes per pod $\left(\mathrm{R}^{2}=0.18\right)$ but this parameter was statistically significant. Although we observed a positive correlation between tree species richness and the number of CPB larvae per pod $\left(\mathrm{R}^{2}=0.21\right)$ in $\mathrm{TFG}$, the difference was not significant. Similar observation was made with canopy cover and the number of CPB larvae per pod $\left(\mathrm{R}^{2}=0.12\right)$. 


\section{Discussion}

Our results support the insurance hypothesis, which states that biodiversity insures ecosystems against loss in their functioning when environmental conditions change (Ives et al. 2000; Perfecto et al. 2004; Philpott and Armbrecht 2006). In this study, an increase in the number of baits (on the trees and ground) in traditional cocoa forest gardens (TFG) represented the environmental change. The time to locate baits and the time for recruitment by ants were significantly shorter in the more diverse TFGs (extensive TFG) than the less diverse ones (intensive TFG), resulting in a significant higher number of ant specimen gathered to remove baits. The results also suggest an important potential role for ants in controlling outbreaks in diverse cocoa plantations or in diverse tropical agroforests. Perfecto et al. (2004) demonstrated that higher bird diversity resulted in increased effectiveness against a pest outbreak in coffee agroecosystems. In their case bird abundance was also greater in sites with higher bird richness and they were not able to separate the relative contributions of abundance and richness but suggested the increased richness to be responsible of the observed results. In our study foraging observations support the idea that a higher richness of ant species is responsible for higher predation. Also, because the ant abundance was not greater in TFG with higher ant richness, we suggest a significant contribution of richness in increased pest control because of a positive correlation between richness and the time for recruitment of ants at baits. Data on pods loss to cocoa pod borers (CPB), CPB larvae per pod, damages caused by SS or Heliopeltis sp and the population dynamic of SS per TFG support the hypothesis that density of functionally monophagous herbivores will be reduced with increased vegetational diversity. Moreover, our results showed a positive association between ant species richness and vegetational diversity. It is known that in agroecosystems ants plays an important role in biological control by chemically deterring pests feeding (Carrol and Risch 1983; Khoo and Chung 1989; Way and Khoo 1992; See and Khoo 1996) or directly by preying upon them. This behaviour is particularly important for plant-sucking insects such as SS and Heliopeltis sp that require a substantial amount of time to locate the appropriate host tissue for feeding (Khoo and Chung 1989). However, the density of particular effective predator species and/or a higher species richness of ants may contribute in the mechanism responsible for the functioning of the insurance hypothesis. 
A higher richness of ants may enhance their ability to adapt and respond to changing conditions such as pest outbreaks or exploit new resources efficiently. However, the increased ecosystem function is not only due to diversity per se but rather the intraspecific differences in foraging or behaviour within ant communities that help to enhance the response to herbivory or may boost functionality under the insurance hypothesis (Yachi and Loreau 1999). In order word the higher ant diversity increases the probabilities that a highly efficient species or set of species are present and they are responsible for the increased ecosystem function. In this study, it is possible that two species the Crematogaster sp and Oecophylla longinoda were responsible for most baits removal and the low damages caused by the cocoa pod borers, SS and Heliopeltis sp or the low population of SS in the diverse TFGs.

Traditional cocoa forest gardens were replicated in our experimental design and no significant difference were found in the temperature, relative humidity (although temperature decreases while relative humidity increases with intensification) and light intensity under canopy trees between TFG suggesting that the observed differences in predation was due to the difference in floristic and structural diversity between TFGs, thus confirming our hypothesis. Our results also show that ground foraging ants play minor and/or secondary role in predation in tropical agroecosystems and may rely mostly on little prey that fall to the forest floor when disturbed by arboreal conspecifics. Nevertheless, Homopteran aggregations provide a rich and permanent food supply to arboreal ant species in cocoa plantations (Jackson, 1984; Phipott and Armbrecht 2006) while almost none of the common plant in the herb layer had extrafloral nectaries which are high energy and predictable food source.

Structural and floristic diversity of traditional cocoa forest maintain higher diversity and density of ants that can act to buffer the system, because of asynchronicity of their response, when environmental conditions changes as they inevitably do. Care should therefore be taken when promoting intensification and simplification of diverse agroforestry systems such as TFGs that sustain the livelihoods of millions of smallholder farmers in the tropics. However, it is important to assess the cost-benefit ratio between biodiversity, profitability and ecosystem services in traditional cocoa forest gardens in the tropics before any conservation policies are designed. 


\section{Acknowledgments}

Financial assistance was provided by the University of Goettingen (IPAG "International $\mathrm{PhD}$ Programme in Agricultural Sciences in Goettingen"). We thank CIRAD, Cameroon for logistic support during field works; the staff of the Laboratory of Entomology at the "Institut de la Recherche Agricole pour le Développement" (IRAD) in Nkolbisson, Cameroon: M. Djalla, AD. Missoup, V. Ondoua, J. Nzomo, JC. Mongo, N. Essomo, C. Ngoum Esse and V. Koumpia and smallholder cocoa farmers for help in the field.

\section{References}

Carroll C.R. and Risch S.J. (1983) Tropical annual cropping systems: Ant ecology. Envir. Management, 7: $51-57$.

Chapin F.S. III, Zavaleta E.S., Eviner V.T., Naylor R.L., Vitousek, P.M., Reynolds H.L., Hooper D.U., Lavorel S., Sala O.E., Hobbie S.E., Mack M.C. and Diaz S. (2000) Consequences of changing biodiversity. Nature, 405: 234-242.

Davidson D.W., Cook S.C., Snelling R. and Chua T.H. (2003) Explaining the abundance of ants in lowland tropical rainforest canopies. Science, 300: 969 - 972.

Delabie J.H.C., Fisher B.L., Majer J.D., and Wright I.W. (2000) Sampling effort and choice of methods. In: ants: Standard methods for measuring and monitoring biodiversity (eds Agosti, D., Majer, JD., Alonso, LE. And Schultz, TR.) pp 145-154. Smithsonian Institution Press, Washington.

Duffy J.E. (2002) Biodiversity and ecosystem function: The consumer connection. Oikos, 99: $201-219$.

Elton C. (1958) Ecology of invasions by animals and plants. Chapman \& Hall, London. 
France K.E. and Duffy E. (2006) Diversity and dispersal interactively affect predictability of ecosystem function. Nature, 441: 1139 - 1143.

Giller P.S., Hillebrand H., Berninger U-G., Gessner M.O., Hawkins S., Inchausti P., Inglis C., Leslie H., Malmqvist B., Monaghan M.T., Morin P.J., O'Mullan G. (2004) Biodiversity effects on ecosystem functioning: emerging issues and their experimental test in aquatic environments. Oikos, 104: $423-436$.

Gove A.D. and Majer J.D. (2006) Do isolated trees encourage arboreal ant foraging at ground-level? Quantification of ant activity and the influence on season, in Veracruz, Mexico. Agric. Ecosyst. and Envir. 113: 272-276.

Greenberg R. Bichier P. and Cruz Angon A. (2000) The conservation value for birds of cocoa plantations with diverse planted shade in Tabasco, Mexico. Anim. Conserv. 3: 105 -112 .

Hooper D., Chapin F.S.III., Ewel J., Hector A., Inchausti P., Lavorel S., Lawton J., Lodge D., Loreau M., Naeem S., Schmid B., Setälä H., Symstad A., Vandermeer J. and Wardle D. (2005) Effects of biodiversity on ecosystem functioning: a consensus of current knowledge. Ecolo. Monographs, 75: 3 - 35.

Ives A.R., Klug J.L. and Gross K. (2000) Stability and species richness in complex communities. Ecol. Letters, 3: 399 - 411.

Jackon D.A. (1984) Ant distribution patterns in a Cameroonian cocoa plantation: Investigation of the ant mosaic hypothesis. Oecologia ${ }_{2} 62: 318-324$.

Khoo K.C. and Chung G.F. (1989) Use of the black cocoa ant to control mirid damage in cocoa. The planter, 65: $370-383$. 
Khoo K.C. and Ho C.T. (1992) The influence of Dolichoderus thoracicus (Hymenoptera: Formicidae) on losses due to Heliopeltis theivora (Heteroptera: Miridae), black pod disease, and mammalian pests in cocoa in Malaysia. Bull. Entomol. Res. 82: 485 - 491.

Klein A., Steffan-Dewenter I., Buchori D., \& Tscharntke T. (2002) Effects of land-use intensity in tropical agroforstry systems on coffee flower-visiting and trap-nesting bees and wasps. Conserv. Biol. 16: 1003-1014.

Loreau M., Mouquet N. and Gonzalez A. (2003) Biodiversity as spatial insurance in heterogeneous landscapes. PNAS, 22: 12765 - 12770.

Majer, J.D. (1976) The influence of ants and ant manipulation on the cocoa farm fauna. J. of Appl. Ecol. 13: 157-175.

Majer, J.D. (1994) Arboreal ant community patterns in Brazilian cocoa farms. Biotropica, 26: 73-83.

Naeem S. and Li S. (1997) Biodiversity enhances ecosystem reliability. Nature, 390: 507 -509 .

Peeters P.J., Read J. and Sanson G.D. (2001) Variation in the guilt composition of herbivorous insect assemblages among co-occuring plant species. Austral Ecol. 26: 385399.

Perfecto I., Rice R.A., Greenberg R., and Voort M.E. (1996) Shade coffee: a disappearing refuge for biodiversity. Shade coffee plantations can contain as much biodiversity as forest habitats. BioScience, 46: 598-608.

Perfecto I., Vandermeer J.H., Bautista G.L., Ibarra Nuñez G., Greenberg R., Bichier P., and Langridge S. (2004) Greater predation in shaded coffee farms: The role of resident neotropical birds. Ecology, 85: 2677 - 2681. 
Philpott S. and Armbrecht I. (2006) Biodiversity in tropical agroforests and the ecological role of ants and ant diversity in predatory function. Ecolo. Entomol. 31: 369 - 377.

Philpott S., Greenberg R., and Bichier P. (2005) The influence of ants on the foraging behavior of birds in an agroforest. Biotropica, 37: $468-471$.

Philpott S., Greenberg R., Bichier P. And Perfecto I. (2004) Impacts of major predators on tropical agroforest arthropods: comparisons within and across taxa. Oecologia, 140: $140-149$.

Power A.G. and Flecker A.S. (2000) Agroecosystems and Biodiversity. http://www.si.edu/smbc/cacao/power.htm

Ribas C.R., Schoereder J.H., Pic M., and Soares S.M. (2003) Tree heterogeneity, resource availability, and larger scale processes regulating arboreal ant species richness. Austral Ecol. 28: 305-314.

Roth D.S., Perfecto I., \& Rathcke B. (1994) The effects of management systems on ground-foraging ant diversity in Costa Rica. Ecolo. Applic. 4: 423-436.

See Y.A. and Khoo K.C. (1996) The influence of Dolichoderus thoracicus (Hymenoptera: Formicidae) on cocoa pod damage by Conopomorpha cramerella (Lepidoptera: Gracillariidae) in Malaysia. Bull. of Entomol. Res. 86: 467 - 474.

Siebert, S.F. (2002) From shade-to sun-grown perennial crops in Sulawesi, Indonesia: Implications for biodiversity conservation and soil fertility. Biodivers. and Conserv. 11: 1889-1902.

Sperber CF., Nakayama K., Valverde MJ., \& Neves FS. (2004) Tree species richness and diversity affect parasitoid diversity in cacao agroforestry. Basic and Appl. Ecol. 5: 241151. 
Steele R.G. and Torrie J.H. (1960) Principles and procedures of statistics with special reference to the biological science. McGraw - Hill Book Co., New York. 481 pp.

Tscharntke T. and Brandl R. (2004) Plant-Insect interactions in fragmented landscapes. Ann. Rev. Entomol. 49: 405 - 430.

Way M.J. and Khoo K.C. (1989) Relationship between Heliopeltis theobromaa damage and ants with soecial reference to Malaysian cocoa smallholdings. J. Prot. Tropics, 6: 1 11.

Way M.J. and Khoo K.C. (1992) Role of ants in pest-management. Ann. Rev. Entomol. 37: $479-503$.

Yachi S. and Loreau M. (1999) Biodiversity and ecosystem productivity in a fluctuating environment: The insurance hypothesis. Proc. Natl. Acad. Sci. 96: 1463 - 1468. 


\section{List of Figures}
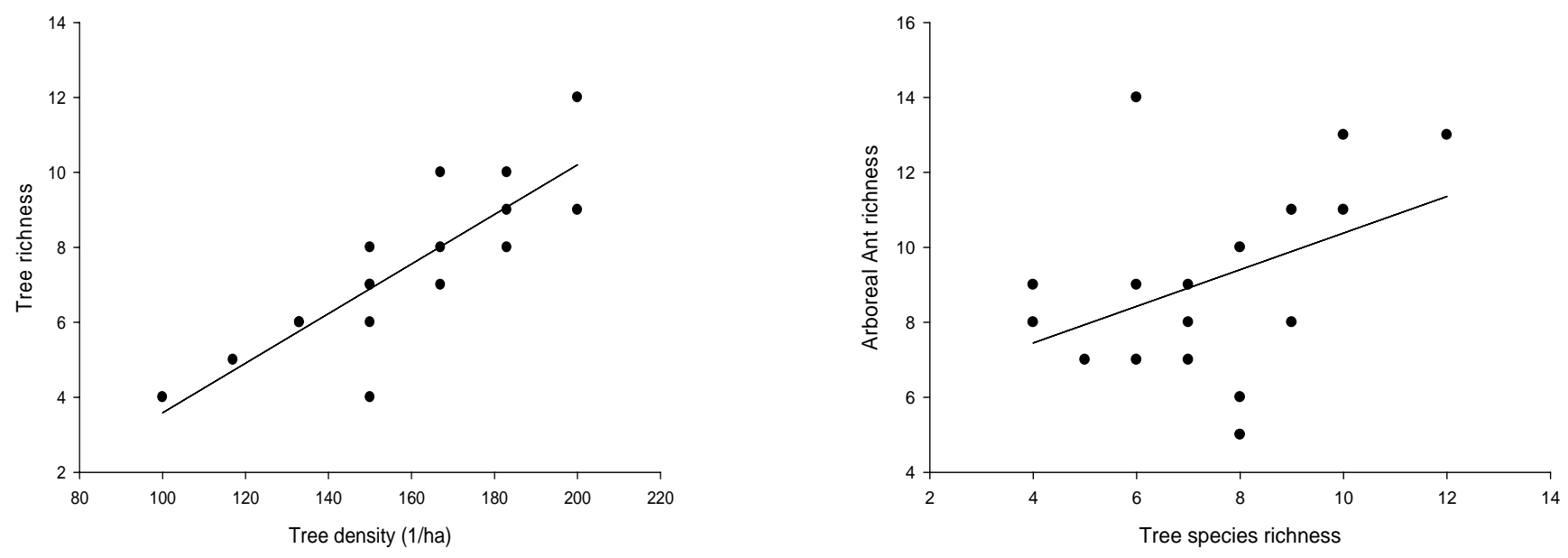

Figure 1. Relationship between tree species richness and tree density; tree species richness and arboreal ant species richness in TFG
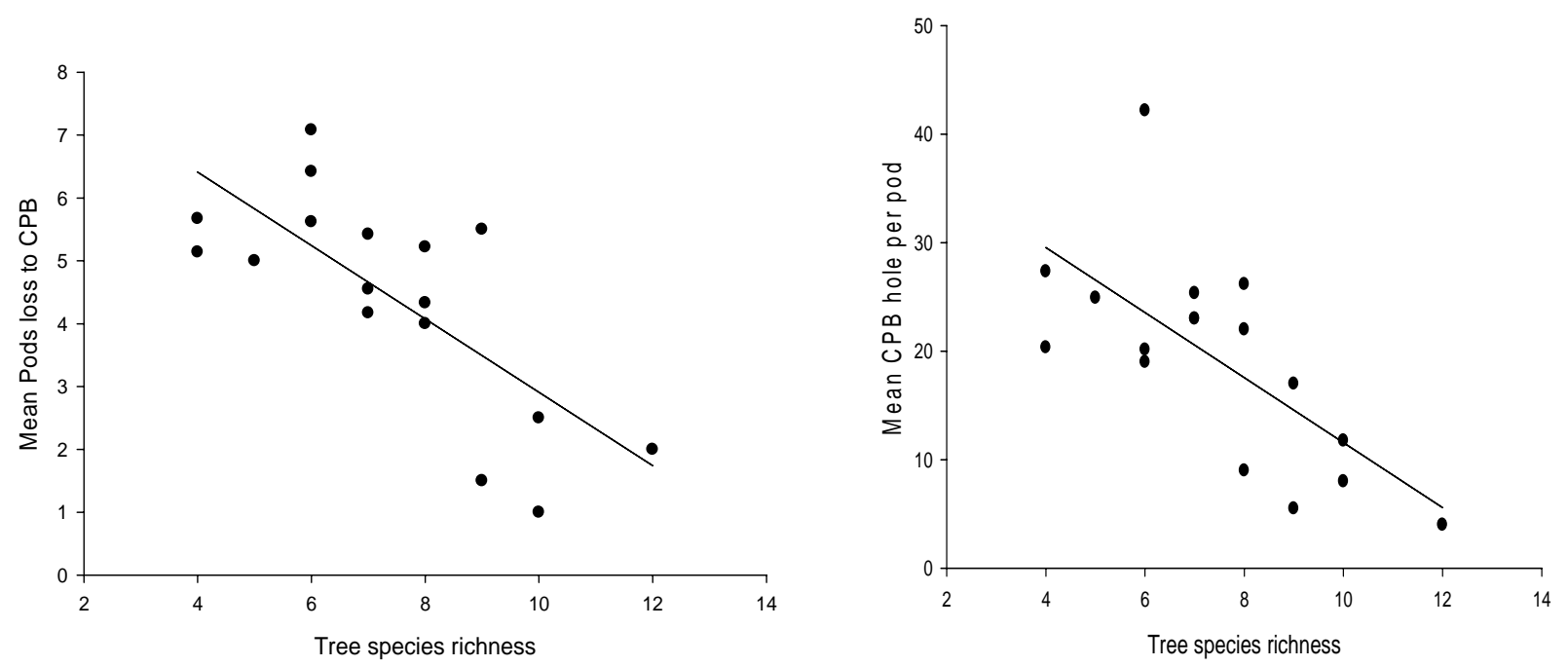

Figure 2. Influence of tree species richness on pod loss to $\mathrm{CPB}$ and $\mathrm{CPB}$ holes per pod in TFG 

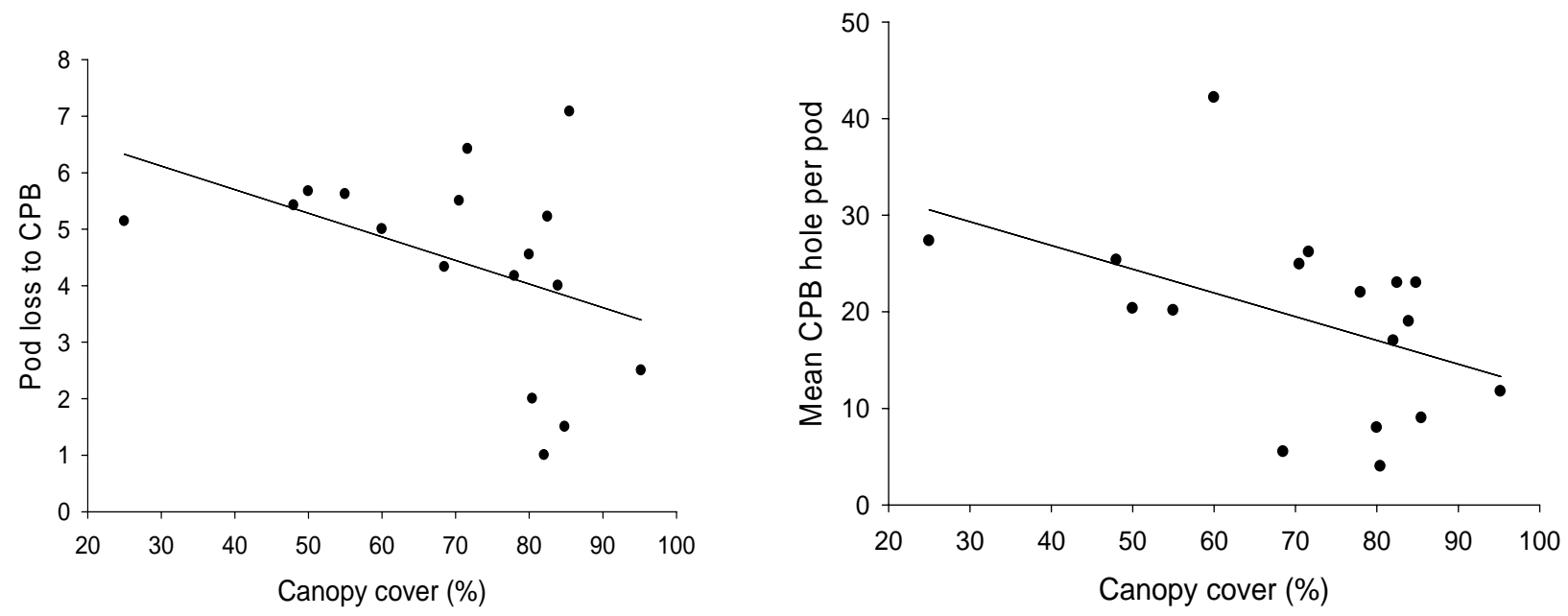

Figure 3. Relationship between canopy cover, pod loss to CPB and CPB holes per cocoa pod in TFG 


\section{List of Tables}

Table 1. Vegetational characteristics at 17 traditional cocoa forest gardens (TFG) in southern Cameroon

\begin{tabular}{ccrcccc}
\hline $\begin{array}{c}\text { Type } \\
\text { of TFG }\end{array}$ & \multicolumn{2}{c}{ Tree species } & Herbaceous species & $\begin{array}{c}\text { Canopy cover } \\
(\%)\end{array}$ & $\begin{array}{c}\text { Herbaceous } \\
\text { Cover }(\%)\end{array}$ \\
& Total & Average $\dagger$ & Total & Average $\dagger$ & \\
\hline EO & 18 & $11.0^{\mathrm{c}}(1.00)$ & 53 & $33.0^{\mathrm{c}}(3.00)$ & $87.8^{\mathrm{c}}(7.39)$ & $84.7^{\mathrm{c}}(15.33)$ \\
EY & 20 & $6.5^{\mathrm{b}}(0.65)$ & 54 & $25.8^{\mathrm{b}}(2.36)$ & $73.5^{\mathrm{b}}(3.99)$ & $78.2^{\mathrm{c}}(4.83)$ \\
HG & 24 & $9.0^{\mathrm{bc}}(0.58)$ & 55 & $25.0^{\mathrm{b}}(2.52)$ & $83.6^{\mathrm{c}}(0.82)$ & $22.1^{\mathrm{b}}(5.76)$ \\
IM & 23 & $7.5^{\mathrm{b}}(0.65)$ & 35 & $17.3^{\mathrm{a}}(1.83)$ & $75.7^{\mathrm{b}}(2.91)$ & $8.2^{\mathrm{a}}(1.53)$ \\
IY & 17 & $5.3^{\mathrm{a}}(0.75)$ & 61 & $25.5^{\mathrm{b}}(1.85)$ & $44.5^{\mathrm{a}}(12.99)$ & $32.7^{\mathrm{b}}(8.00)$ \\
$p$ & & $* *$ & & $* *$ & $* *$ & $* * *$ \\
\hline
\end{tabular}

Notes: ${ }^{* *} p<0.01 ; * * * p<0.001$; Numbers in parenthesis represent $1 \mathrm{SE}$ of the mean. In a given column, means with different lowercase letters are significantly different at the indicated p-Value.

$\dagger$ Average number of tree and herbaceous species refer to the mean richness per site in each TFG. EO - Extensive manage old cocoa forest gardens; EY - Extensive manage young cocoa forest gardens; HG - Home garden cocoa forests; IM - Intensive manage mature cocoa forest gardens; IY - Intensive manage young cocoa forest gardens 
Table 2. Ant richness and densities at 17 traditional cocoa forest gardens (TFG) in southern Cameroon

\begin{tabular}{ccccccccc}
\hline $\begin{array}{c}\text { Type of } \\
\text { TFG }\end{array}$ & \multicolumn{2}{c}{ Arboreal ant species } & \multicolumn{2}{c}{$\begin{array}{c}\text { Arboreal ant } \\
\text { individuals }\end{array}$} & \multicolumn{2}{c}{$\begin{array}{c}\text { Ground ant } \\
\text { species }\end{array}$} & Ground ant individuals \\
& Total & Average $\dagger$ & Total & Average $*$ & Total & Average $\dagger$ & Total & Average $\$$ \\
\hline EO & 17 & $13.0^{\mathrm{b}}(0.2)$ & 1128 & $43.4^{\mathrm{a}}(7.47)$ & 7 & $4.5(0.5)$ & 243 & $31.0^{\mathrm{b}}(1.22)$ \\
EY & 21 & $10.0^{\mathrm{ab}}(1.35)$ & 2472 & $45.2^{\mathrm{a}}(7.18)$ & 13 & $4.5(0.5)$ & 425 & $25.4^{\mathrm{b}}(3.89)$ \\
HG & 17 & $9.3^{\mathrm{a}}(1.67)$ & 1201 & $48.4^{\mathrm{a}}(15.41)$ & 5 & $2.7(0.88)$ & 126 & $19.2^{\mathrm{ab}}(0.44)$ \\
IM & 11 & $6.8^{\mathrm{c}}(0.63)$ & 1550 & $60.1^{\mathrm{b}}(5.49)$ & 12 & $3.8(0.63)$ & 322 & $27.7^{\mathrm{b}}(3.47)$ \\
IY & 15 & $8.5^{\mathrm{a}}(0.65)$ & 1950 & $58.5^{\mathrm{b}}(5.20)$ & 8 & $3.0(0.71)$ & 234 & $14.0^{\mathrm{a}}(0.20)$ \\
$p$ & & $* *$ & & $* *$ & & NS & & $* *$ \\
\hline
\end{tabular}

Notes: ${ }^{* *} p<0.01$; Numbers in parenthesis represent $1 \mathrm{SE}$ of the mean. In a given column, means with different lowercase letters are significantly different at the indicated p-Value. NS indicates not significant.

$\dagger$ Average number of arboreal and ground foraging ant species refers to the mean richness per site in each TFG.

$\$$ Average number of individuals refers to the mean of $2 \mathrm{hrs}$ counts on baits per site in each TFG; EO - Extensive manage old cocoa forest gardens; EY - Extensive manage young cocoa forest gardens; HG - Home garden cocoa forests; IM - Intensive manage mature cocoa forest gardens; IY - Intensive manage young cocoa forest gardens 
Table 3. Arboreal and ground foraging ant activities such as time to locate baits, time for recruitment and number of specimens foraging after $1 \mathrm{hr}$ in TFG in southern Cameroon

\begin{tabular}{|c|c|c|c|c|c|c|}
\hline \multirow{2}{*}{$\begin{array}{l}\text { Type of } \\
\text { TFG }\end{array}$} & \multicolumn{3}{|c|}{ Arboreal ant species } & \multicolumn{3}{|c|}{ Ground foraging ant species } \\
\hline & Tlb (mn) & $\operatorname{Tfr}(m n)$ & $1 \mathrm{~h}$ & Tlb (mn) & $\operatorname{Tfr}(m n)$ & $1 \mathrm{~h}$ \\
\hline & $\mathrm{P}=0.002$ & $\mathrm{P}<0.001$ & $\mathrm{P}<0.001$ & NS & NS & $\mathrm{P}=0.001$ \\
\hline EO & $8.9^{\mathrm{b}}(0.30)$ & $3.6^{\mathrm{a}}(0.40)$ & $60.6^{\mathrm{c}}(2.40)$ & $13.1(0.50)$ & $19.7(4.30)$ & $21.2^{\mathrm{bc}}(1.00)$ \\
\hline EY & $6.6^{\mathrm{a}}(1.00)$ & $13.1^{\mathrm{c}}(0.77)$ & $19.6^{\mathrm{a}}(2.47)$ & $13.1(3.82)$ & $10.8(5.40)$ & $15.5^{\mathrm{b}}(4.58)$ \\
\hline HG & $11.5^{\mathrm{c}}(0.18)$ & $19.9^{\mathrm{d}}(4.64)$ & $20.0^{\mathrm{a}}(1.83)$ & $17.4(5.17)$ & $16.7(5.83)$ & $8.6^{\mathrm{a}}(1.33)$ \\
\hline IM & $9.9^{\mathrm{b}}(0.37)$ & $16.9^{\mathrm{d}}(1.55)$ & $46.5^{\mathrm{b}}(5.64)$ & $16.5(0.68)$ & $16.0(4.10)$ & $6.5^{\mathrm{a}}(1.73)$ \\
\hline IY & $7.1^{\mathrm{a}}(0.20)$ & $7.4^{\mathrm{b}}(1.12)$ & $23.9^{\mathrm{a}}(3.82)$ & $16.3(2.93)$ & $13.9(3.03)$ & $30.1^{\mathrm{c}}(2.79)$ \\
\hline$p$ & ** & $* * *$ & *** & NS & NS & ** \\
\hline
\end{tabular}

Notes: ${ }^{* *} p<0.01 ;{ }^{* *} p<0.001$; Tlb: Time to locate baits; Tfr: Time for recruitment; $1 \mathrm{~h}$ : Number of specimen at baits after $1 \mathrm{~h}$ observation

Numbers in parenthesis represent $1 \mathrm{SE}$ of the mean. In a given column, means with different lowercase letters are significantly different at the indicated p-Value. NS indicates not significant 
Table 4. Average pod loss to cocoa pod borers (CPB); mean number of holes caused by CPB; mean number of CPB larvae per pod; mean number of fresh lesions caused by $S$. singularis and Heliopeltis sp and average number of mirids per cocoa tree in TFG in southern Cameroon

\begin{tabular}{|c|c|c|c|c|c|c|}
\hline $\begin{array}{c}\text { Type of } \\
\text { TFG }\end{array}$ & $\begin{array}{c}\text { Pods loss to } \\
\text { CPB }\end{array}$ & $\begin{array}{c}\text { Holes } \\
\text { caused by } \\
\text { CPB }\end{array}$ & $\begin{array}{c}\text { CPB larvae } \\
\text { per Pod }\end{array}$ & $\begin{array}{c}\text { Fresh } \\
\text { lesions } \\
\text { caused by } S \text {. } \\
\text { singularis }\end{array}$ & $\begin{array}{c}\text { Fresh lesions } \\
\text { caused by } \\
\text { Heliopeltis sp }\end{array}$ & $\begin{array}{c}\text { Mirids } \\
\text { dynamic }\end{array}$ \\
\hline & $\mathrm{P}=0.002$ & $\mathrm{P}=0.001$ & $\mathrm{P}<0.001$ & $\mathrm{P}=0.002$ & $\mathrm{P}<0.001$ & $\mathrm{P}=0.001$ \\
\hline $\mathrm{EO}$ & $2.3^{\mathrm{a}}(0.25)$ & $7.9^{\mathrm{a}}(3.88)$ & $0.0^{\mathrm{a}}(0.00)$ & $9.5^{\mathrm{a}}(2.52)$ & $23.8^{\mathrm{a}}(0.60)$ & $1.5^{\mathrm{a}}(0.5)$ \\
\hline EY & $5.2^{\mathrm{b}}(0.63)$ & $23.3^{\mathrm{b}}(1.80)$ & $6.5^{\mathrm{b}}(1.71)$ & $12.6^{\mathrm{b}}(0.28)$ & $31.0^{\mathrm{a}}(5.01)$ & $2.0^{\mathrm{a}}(0.41)$ \\
\hline $\mathrm{HG}$ & $2.2^{\mathrm{a}}(0.93)$ & $7.5^{\mathrm{a}}(1.04)$ & $0.0^{\mathrm{a}}(0.00)$ & $17.6^{\mathrm{c}}(0.77)$ & $89.4^{b}(7.35)$ & $12.0^{\mathrm{c}}(1.53)$ \\
\hline $\mathrm{IM}$ & $5.3^{\mathrm{b}}(0.46)$ & $20.2^{\mathrm{b}}(1.37)$ & $0.5^{\mathrm{a}}(0.50)$ & $14.2^{b}(1.13)$ & $59.9^{\mathrm{b}}(4.42)$ & $6.8^{\mathrm{b}}(2.10)$ \\
\hline IY & $5.5^{\mathrm{b}}(0.12)$ & $29.1^{\mathrm{b}}(4.42)$ & $20.0^{\mathrm{c}}(0.82)$ & $13.0^{\mathrm{b}}(1.58)$ & $59.5^{\mathrm{b}}(6.99)$ & $7.5^{\mathrm{b}}(0.29)$ \\
\hline$p$ & $* *$ & $* *$ & $* * *$ & $* *$ & $* * *$ & $* *$ \\
\hline
\end{tabular}

Notes: $* * p<0.01 ; * * * p<0.001$; Numbers in parenthesis represent $1 \mathrm{SE}$ of the mean. In a given column, means with different lowercase letters are significantly different at the indicated p-Value. EO - Extensive manage old cocoa forest gardens; EY - Extensive manage young cocoa forest gardens; HG - Home garden cocoa forests; IM - Intensive manage mature cocoa forest gardens; IY - Intensive manage young cocoa forest gardens 


\title{
Biodiversity, yield, net income and vegetation structure in traditional cocoa forest gardens in southern Cameroon
}

\author{
${ }^{1,2}$ Hervé D. B. Bisseleua and ${ }^{1}$ Stefan Vidal \\ ${ }^{1}$ Georg-August-University Goettingen, Department of Crop Sciences, Entomological \\ Section, Grisebachstr. 6, 37077 Goettingen, Germany; ${ }^{2}$ Institute of Agricultural Research \\ for Development (IRAD), Nkolbisson Regional Research Centre, BP 2067, Yaoundé, \\ Cameroon.
}

Corresponding author: Hervé D. B. Bisseleua; email: hbissel@gwdg.de

\begin{abstract}
World chocolate demand is expected to more than double by 2050 . Decisions about how to meet this challenge will have profound effects on tropical rainforest and wild species in producing countries. Cocoa "the chocolate tree" is produced traditionally under a diverse and dense canopy of shade trees that provide habitats for a high biodiverse associated organisms. The current trend to reduce or eliminate shade cover and the international price recovery raises concerns about the potential loss of biodiversity. However, few studies have assessed the ecological losses and economic tradeoffs under different management options. We study the relationship between species richness, composition and abundance of ants to vegetation structure, ecosystem function and economic profitability under different land-use management in 17 traditional cocoa forest gardens in southern Cameroon. The index of profitability was based on the net annual income per hectare. Significant differences were found associated with the different land-use management for species richness and abundance of ant and species richness and density of trees. Ant species richness was significantly greater in floristically and structurally diverse extensive old cocoa systems. Ant species richness revealed statistical significant effects of tree species richness and density. Ecosystem functioning showed a significant responses to shade cover reductions in TFGs for herbivory and above ground plant biomass. Our model showed no clear relationship between biodiversity and profitability. However, we suggest that to improve income and
\end{abstract}


livelihoods of smallholders cocoa farmers, economic incentives are required to prevent further intensification beyond ecologically acceptable shade cover. Certification programs for shade-grown cocoa may provide socio-economic drives to slow down ongoing intensification trends.

Keywords: agroforestry management, land-use management, agricultural economics, cocoa, ants, ecosystem function, cocoa certification program.

\section{Introduction}

Agricultural production strongly influence biodiversity and ecosystem processes in a variety of habitats, often changing community composition, plant biomass, vegetation structure and nutrient cycling due to the interactions between biological, social and economics factors (Greenberg et al. 2000, Reitsma et al. 2001, Duffy 2002, Phipott and Dietsch 2003, Dietsch et al. 2004, Perfecto et al. 2005, Phippott et al. 2006, Klein et al. 2006, Gordon et al. 2007, Steffan-Dewenter et al. 2007).

Traditional cocoa forest garden (TFG) is one of the diverse agroecosystems that has received considerable attention from researchers and conservation organizations in recent years (Klein et al. 2002a,b, Klein et al. 2003a, Sperber et al. 2003, Perfecto et al. 2004, Schroth et al. 2004, Philpott and Armbrecht 2006). In these traditional plantations, cocoa is grown under a structurally and floristically diverse canopy of shade trees that provide habitat for a high diversity of associated flora and fauna (Zapfack et al. 2002, Bobo et al. 2006). These traditional plantations are enriched by non-timber forest products (Duguma et al. 2001) and maintain many of the ecological characteristics of natural forests. Such multiresource land-use practices that create new landscape elements offer more scope for conservation of biodiversity, at both species-level and landscape-level, could help in pests and diseases regulation or allows for efficient adaptation to changing socioeconomic conditions, ecological conditions, household needs and marketing opportunities (Perfecto et al. 2005); or could provide more opportunities in developing new approaches in conservation of tropical rainforests and biodiversity, as well as increased recognition of indigenous land-use systems as a possible way for sustainable development (Donald 2004, Schroth et al. 2004). 
However, since the late 1980s, the cacao sector has been subjected to several major economic shocks that have led to new institutional and organizational frameworks in southern Cameroon. The drastic fall in world prices of cacao and other commodities at the time contributed to substantial domestic economic problems. Cacao farmers responded to the crisis by increasing their activity in food crop production to compensate for the lost income. This in turn led to a very significant increase in forest clearing with its attendant profound negative environmental, economic and political consequences.

The current trend to reduce or eliminate shade cover in cocoa and the international price recovery (ICCO 2005) suggests that cocoa production in southern Cameroon is likely to remain a major contribution to deforestation at the forest-agriculture interface where much pristine forest remains.

There are very few studies on the trade-offs between biodiversity loss and agricultural intensification (Perfecto et al. 2005, Gordon et al. 2007 and Steffan-Dewenter et al. 2007). Two opposing models are proposed concerning the value of intensification for conservation; either wildlife-friendly farming on the cost of agricultural yields (Philpott and Dietsch 2003, Dietsch et al. 2004) or land sparing by agricultural intensification to minimize the demand for natural habitat (O'Brien and Kinnaird 2003, Rappole et al. 2003a,b). But Green et al. (2005) showed that the best type of farming for species persistence depends on the relationship between species richness and yields.

Due to the sociopolitical and economic dimensions of cocoa, policy makers and smallholder cocoa farmers need to be familiar with the role of biodiversity in cocoa farming and the cost-benefit ratio associated (Donald 2004, Steffan-Dewenter 2007). Greenberg (1998) argues that the conservation of shade-grown cocoa plantations needs to entails financial incentives for the grower and ecosystem services for the consumer. The incentives could be derived in four ways: (1) if the market is willing to purchase more environmentally-friendly products; (2) if the financial benefits of the ecological services arising from shade production is acknowledged; (3) if the income derived from non-crop plants is valued; and (4) if there are national or international programs to subsidize lowintensity management. Examples of synergistic interactions between biodiversity and profitability have been demonstrated in many agroecosystems, and include the control of pest populations by a diverse community of predatory, or "beneficial", arthropods, increased pollination services to crop plants by native pollinating insects, increased soil 
nitrogen availability by the $\mathrm{N}$-fixing microbes of leguminous plants and increased carbon sequestration (Kotto-Same et al. 1993, Vandermeer 1995, Pimentel et al. 1997, RomeroAlvarado et al. 2002, Soto-Pinto et al. 2002, Klein et al. 2003a,b Perfecto et al. 2004, Philpott et al. 2006, Steffan-Dewenter et al. 2007).

Steffan-Dewenter et al. (2007) provided evidence of complexity of the relationship between biodiversity and profitability in cocoa agroecosystems in Indonesia. This relationship may include synergies as well as trade-offs. If the two parameters are well understood in cocoa, land-use management, agronomic practices and policies can be planned to generate significant returns for smallholder cocoa farmers and help to implement efficient and successful tropical rainforests biodiversity conservation programs.

We used traditional cocoa forest gardens in southern Cameroon to evaluate the ecological consequences of agricultural intensification on species richness and ecosystem functions and the economic implications. We hypothesized that (i) land-use intensification in traditional cocoa forest garden negatively affect diversity of ants, insect herbivory and above ground plant biomass; (ii) ant species richness and abundance are positively related to tree species richness and density; (iii) ant species richness are positively related to yield and income (expressed in net income).

\section{Material and method}

\section{Study system}

Cocoa is the world's third most important agricultural export commodity cultivated on 6.99 million ha with a world production of 3289 million tones and a production value of \$USD 7 billion in 2004/2005 (ICCO 2005). Cocoa is a major source of foreign income for the countries that dominate production with $72 \%$ of the world's cocoa produced in West Africa (Côte d'Ivoire, Ghana, Nigeria and Cameroon) (ICCO 2005). Annual production in Cameroon for the year 2004/2005 average 180 thousand tones, concentrated mainly in the humid rainforest area. Cocoa cultivation is grown under a gradient canopy of shade (Chapter 1). Our study areas were located between $2^{\circ} 35^{\prime} \mathrm{N}$ and $4^{\circ} 15^{\prime} \mathrm{N}$ and $11^{\circ} 48^{\prime}$ and $11^{\circ} 15^{\prime} \mathrm{E}$. The altitude varies between 450 and $715 \mathrm{~m}$ above sea 
level and is characterized by a sub-equatorial climate, with a bimodal rainfall regime. The mean annual temperature varies between $25^{\circ} \mathrm{C}$ with a relatively small thermal variation. The mean annual rainfall is around $1900 \mathrm{~mm}$. The soils are Oxisols/Ultisols, which make up about $80 \%$ of the soils in the humid forest region of Cameroon and the $\mathrm{pH}$ of the soil varies from 4.29 to 5.43 (Kotto-Same et al. 1997; Kanmegne et al. 2006).

We selected 17 traditional cocoa forest gardens (TFGs) covering a gradient in canopy cover from $95 \%$ shading to $40 \%$ as follow: Extensive manage old cocoa forest garden (EO 50 years) with about $90 \%$ shading; Extensive manage young cocoa forest garden (EY $\sim 25$ years) $\sim 75 \%$ shading; Intensive manage old cocoa forest garden (IM $\sim 25$ years) $\sim 70 \%$ shading; Intensive manage young cocoa forest garden (IY 15 years) with an average of $40 \%$ shading; and Home cocoa forest garden ( $\mathrm{HG} \sim 35$ years) $\sim 80 \%$ shading. Two cocoa plantations were selected in EO, four in EY, IM and IY respectively and three in HG. These 17 study sites had a minimum size of 1 ha and a minimum distance to the nearest neighbour of $500 \mathrm{~m}$.

\section{Plant and ant surveys}

Vegetation characteristics, basal area (BA), above ground calculations, abiotic and canopy cover measurements are summarized in Chapter 1. Ant survey is summarized in Chapter 8.

\section{Biotic interactions}

Herbivory rates were quantified by assessing the number of pods loss to cocoa pod borers (CPB) and the cocoa mirids Salhbergella singularis Hag. (Hemiptera: Miridea) (SS) on 30 randomly selected cocoa trees per site. Each selected tree was carefully inspected from the base up to hand height level. The hand height level is the highest level to which the assessor's fully stretched hand can reach.

\section{Biodiversity and yield relationship}

We examine ant species richness and cocoa yield along a shade gradient. Species richness was used as a percentage of the mean number of species found per site. This allows us to compare the responses to cocoa intensification. We also apply onto these data percentage 
yield (expressed as the maximum yield attained within a range of shade cover) as they relate to percentage shade cover.

\section{Economic surveys}

Between August and December 2005, 500 cocoa farmers were interviewed individually in the five zones to gather all the economic data necessary to calculate net revenue. We used data from the cocoa campaign 2003, 2004 and 2005. In addition, data were collected on the frequency of weeding, fertilizers and insecticides used.

\section{Statistical analyses}

Multiple linear regression analysis was used to describe the relationship between ant and vegetation variables using ant species richness and ant abundance as dependent variables. Data on species richness, ecosystem function and yield were analyzed by simple regression against canopy cover. Means and standards errors (SEM) are given in the text and figures. A simple linear least square regression analyses between profitability and biodiversity variables was used to examine biodiversity-profitability relationship and ANOVA was used to test for the statistical significance of these relationships. A separate analyzes was performed using ant species richness and abundance data. Net income (NI) calculated in terms of \$ USD per hectare per year, was used as our index of profitability. For the calculation of the NI we included only the most significant annual operating expenditures and revenues. We calculated NI by subtracting management costs (MC) from total revenue (TR). MC was computed as the sum of pesticide costs plus labour costs. Labor and pesticide costs accounted for over $95 \%$ of the annual operating costs reported by cocoa farmers. TR was the sum of cocoa revenue and exotic fruits revenue generated by the plantation. Exotic fruit revenue was calculated by multiplying the number of $\mathrm{kg}$ of fruit harvested and sold per year, by the current market price (FCFA 500 based on the calculation that 1 \$USD = FCFA 500).

Cocoa revenue was calculated by multiplying the production (in $\mathrm{kg} / \mathrm{ha}$ ) of unprocessed cocoa beans, by the price under four different scenarios listed below. Each of these price situations was based on recent market fluctuations and actual market prices that producers receive in this region. 
Situation 1: $\$ 1.1 \mathrm{p} / \mathrm{kg}$ corresponding to the price in January 2001 at the lowest point in the recent cocoa price recovery.

Situation 2: $\$ 1.5 \mathrm{p} / \mathrm{kg}$ corresponding to the actual price of beans in southern Cameroon

Situation 3: $\$ 2.3 \mathrm{p} / \mathrm{kg}$ representing the price in January 2003 due to the political instability in Côte d'Ivoire.

Situation 4: $\$ 3.5 \mathrm{p} / \mathrm{kg}$ representing the premium price that could be assigned to plantations producing organic cocoa.

\section{Results}

\section{Ant diversity patterns over intensification gradient}

A total of 10763 specimens of ants were recorded, thirty species of arboreal and ground foraging respectively. The variation in ant species richness, ant abundance and tree species richness with land-use intensity is summarized in Figure 1. Ant species richness $(\mathrm{F}=3.56, p=0.03, \mathrm{df}=4)$, ant abundance $(\mathrm{F}=5.60, p=0.009, \mathrm{df}=4)$ and tree species richness and density $(\mathrm{F}=12.51, p<0.0001, \mathrm{df}=4)$ showed a significant variation between TFGs across the cocoa intensification gradient (one-way ANOVA, $p<0.01$ ).

EO has the highest mean percent species richness of ant and EY the lowest. HG had significantly the highest mean abundance of ants $(\mathrm{P}<0.01)$. The highest mean percent species richness of tree and density was recorded in EO and the lowest in IY.

\section{Ant - vegetation relationships}

We included four vegetation variables in our analysis of ant - vegetation relationships and we observed a complex pattern of intercorrelation (Table 1). We therefore performed a multiple linear regression analysis with models that included only those vegetation variables with statistically significant effects $(p(\mathrm{t})<0.05)$ to confirm which vegetation variables exerted the most significant effects on ants. From our models it could be concluded that ant species richness responded positively to two vegetation variables: tree species richness and tree density (Table 2). These two variables showed statistically significant effects on species richness of ants in TFGs (Table 2). We recorded a significant power of the model when we used ant species richness as the dependent 
variable $\left(\mathrm{R}^{2}=0.25\right.$, ANOVA, $\left.p<0.001\right)$. Tree density showed the most significant effect on ant species richness in TFGs. No significant effects were recorded between the four vegetation variables and ant abundance in TFGs.

\section{Biodiversity and ecosystem functioning}

We quantified the percent standing above ground plant biomass, based on the maximum biomass recorded within a range of shade cover, and the percent of herbivory, based on the maximum number of pod loss to cocoa pod borer (CPB) and mirids S. singularis (SS) recorded within a range of shade cover, to evaluate the functional consequences of variations in species richness and composition along the shade cover. Percent herbivory significantly increased with reduced shade cover (linear regression $y=111.67-0.60 \mathrm{x}$, $\mathrm{R}^{2}=0.28, F=5.85, p=0.03$ ) (Figure 2) while the percent above ground plant biomass significantly decreased with reduced shade cover (linear regression $\mathrm{y}=1.08 \mathrm{x}-34.87, \mathrm{R}^{2}=$ $0.36, F=8.52, p=0.011$ ) (Figure 2).

\section{Biodiversity and yield relationship}

The relationship between percent yield and percent species richness, based on the percent shade cover and its relationship to yield and species richness is summarized in figure 3. Our findings revealed a concave yield set for ant species richness in TFGs as does taxa with a very sensitivity to a reduction in shade. From figure 3 , it is observed that for a farmer to have $95 \%$ of yield (based on the highest yield that can be achieved within a range of shade intensity) $\mathrm{s} /$ he needs to have $70 \%$ of the species richness of ants and $47 \%$ of shade cover under young intensification systems. But in mature intensification systems a farmer need $60 \%$ of the species richness of ants and $80 \%$ of shade cover to achieve 85 $\%$ of yield. However a plantation with $93 \%$ of the species richness of ants and $96 \%$ of shade cover can generate only $39 \%$ yield. This approach help to examine how much yield and species richness are related in TFGs and can guide farmer's management decisions on how much shade to keep in the plantation, or help to set premium price for shaded cocoa based on how much yield a farm is expected to loose for a given level of shade. We recorded a linear relationship between shade and yield with yield decreasing significantly with increased shade (linear regression $\mathrm{y}=118.19-0.61 \mathrm{x}, F=11.77$, $\left.p=0.004, \mathrm{r}=0.66, \mathrm{r}^{2}=0.44\right)$ (Figure 4$)$. 


\section{Biodiversity and net income relationship}

Our results reported that species richness of ant in TFGs was not correlated to the profitability of cocoa plantations in southern Cameroon (Figure 5). We recorded a negative but non significant linear relationship between net income per unit area (NI) and both ant species richness and ant abundance for all the four pricing scenarios. When we excluded EO in the analysis, we obtained a positive linear relationship between net income and both ant species richness and ant abundance, but these relationships were not statistically significant (ANOVA, $p(F)=0.12 p(F)=0.53$ respectively). If IY was rather excluded the relationship between net income and ant species richness was negative and statistically significant (linear regression $\mathrm{y}=3285.8-146.14 \mathrm{x}, \mathrm{r}^{2}=0.53, F=12.56, \mathrm{p}=$ 0.005).

From figure 6, we noted that cocoa yield, expressed as $\mathrm{kg}$ of beans per hectare, was negatively related to ant species richness but insignificant (ANOVA, $p(F)=0.31$ ). Our analysis revealed a positive and non significant (ANOVA, $p(F)=0.38$ ) relationship between yield and ant species richness in TFGs if EO is excluded. Figure 6 also suggests a concave yield set for ant species richness.

Our results also showed that the profit generated by cocoa farmers was significantly affected by cocoa price (Table 3). Farmers in intensives systems were much more sensitive to changes in cocoa prices. EO was the least profitable for all the four pricing situations. However, if a premium price (price situation 3) is paid to farmers, EO could be more profitable than IM under normal price situation 2. Income from non-cocoa products (exotic fruits) contributed to more profitability of intensives systems when prices were low.

\section{Discussion}

\section{Ant diversity patterns}

These results suggest that changes in land-use management from extensive to intensive as practice in cocoa plantations in southern Cameroon may results in a significant decrease of the diversity of ants in TFGs. Sampling method applied play an important role in defining ant communities, therefore results apply only to species that are active on the 
trunk and surface of cocoa plants and can be dislodged by beating and those species that are attracted to bait (Delabie et al. 2000). Room (1971) recorded 128 species of both arboreal and ground foraging ants in a cocoa farm in Ghana. Ribas et al. (2003) recorded 133 ant species in Brazilian "cerrado" and Wilson (1959), 172 species of ground and arboreal ants in the New Guinea rain forest, suggesting that continuous removal of trees from TFG could result in a significant biodiversity loss. Biodiversity loss may be influence by microclimatic conditions, habitat heterogeneity, resource availability and interactions with other species. These results highlight the importance of traditional cocoa forest gardens with natural shade trees as a reservoir of forest biodiversity (Zapfack et al. 2002, Bobo et al. 2006). However, multitaxon studies are important to ascertain the effectiveness of the biodiversity conservation value of TFGs (Perfecto et al. 2003).

\section{Ant - vegetation relationship}

Our data also showed that ant species richness is affected by the richness and density of the companion trees that form the canopy of TFG. Similar trends were demonstrated for other predatory insects by Ribas et al. (2003) and Sperber et al. (2004) with Peeters et al. (2001) suggesting that variation in plant traits among plant species may promote the development of characteristics functional assemblage on insect associated with each plant species. In this case, interspecific competition and competitive exclusion may result as a consequence of low resource availability. Availability of sufficient amount of resource would slow down interspecific competition, helping coexistence of more ant species, resulting in increased ant species richness. On the other hand, higher tree density may result in higher cover and lower temperature and moisture variation altering the dominance order and reducing evenness (Perfecto et al. 1996; Power and Flecker, 1996; Greenberg et al. 2000; Klein et al. 2002b). We noted a significant and positive correlation of tree richness with tree density as observed in other systems (Ribas et al. 2003) showing relatively low anthropogenic disturbance. Sperber et al. (2003) recorded a negative correlation between tree species richness and tree density in Brazilian cocoa plantations and attributed this fact to human intervention. In addition to the diversity gradient in the shade trees, the land-use intensity gradient differed significantly in shading tree height and canopy cover. Ant species richness significantly decreased with increasing canopy cover suggesting that the shadow caused by the canopy appears to be a major factor 
influencing ant community in TFG. These results are consistent with the findings of Perfecto and Vandermeer (1996) and Armbrecht and Perfecto (2003).

\section{Biodiversity and ecosystem functioning}

Ecosystem functioning showed a significant responses to shade cover reductions in TFGs for herbivory and above ground plant biomass. We could suggest that the transition from extensive systems with heavy shade to intensive ones with reduced or open shade is likely to lead to a significant decline in ecosystem functioning with more regular pest outbreaks as well as other ecosystem services as a consequence. Klein et al. (2006) showed that ecosystem functioning such as biological control is enhanced when plantations are close to the natural forest. By selecting TFGs at the forest margin or in the forest, our results quantify the effect of land-use management in TFGs on biodiversity and profitability but also showed that biotic interactions vary significantly along the studied intensification gradient. Moreover, Klein et al. (2003a) have shown that functional group diversity and biological pest control in agroforestry systems are positively related. Pertinent to these findings is the "insurance hypothesis", which suggests that a high level of species richness in TFGs will contribute to its high overall resilience (Ives et al. 2000; Perfecto et al. 2004; Philpott and Armbrecht 2006).

The significant decline in plant biomass may results in a significant loss of carbon (Kotto-Same et al. 1997) and a decline in the rate of biomass accumulation and stands age, increasing the vulnerability of small cocoa farmers to market fluctuations (Duguma et al. 2001, Coulibaly et al. 2002). More biodiverse, lower input systems such as EO and those with non-cocoa revenue generators, incur less economic risk, preventing smallholder cocoa farmers against drastic price drop.

\section{Biodiversity and yield relationship}

Our findings unlike those demonstrated by Perfecto et al. (2005) on coffee, reported a linear relationship between shade and yield and described a concave set of relationship between yield and ant species richness in TFGs. The relationship between yield and species richness is concave for organisms that are sensitive to shade and convex for resistant organisms (Perfecto et al. 2005). This implies that there is a possibility to establish effective premiums for shade cocoa for the purpose of conserving biodiversity. 
However, different components of biodiversity could differ in their sensitivity to the shade management. Therefore conservation of highly sensitive taxa goes with the will for lower yield that will result from a higher density of shade. Furthermore, analysis of the relationship between yield and species richness suggest that increasing premium values may generate a dramatic shift from a high yield-low species richness to a low-yield and high species richness. However, what we could learn from our results is that high yields obtained with intensification in TFGs do not necessarily reduce ant biodiversity if the proper shade vegetation structure is maintained. Policies and incentives aiming at helping farmers overcome the costs of conversion from low-biodiversity systems to more biodiverse systems as that of EO may, therefore, generate simultaneous increases in the biodiversity and net income of TFGs.

\section{Biodiversity and net income relationship}

We provided a direct measurable assessment of the biodiversity-net income relationship in cocoa. Our models indicate that there is not a simple trade-off between biodiversity and net income. Therefore, biodiverse TFGs are not necessarily less profitable than lowbiodiverse ones (Figure 5). Considering only the relationship between cocoa yield and ant species richness and ignoring all production costs, still demonstrate the complexity of the relationship (Figure 3). However, to improve income and livelihoods of smallholders cocoa farmers, economic incentives are required to prevent further intensification beyond ecologically acceptable shade cover. Incentives may be in the form of organic and fair trade certification where farmers receive directly a high price premiums or have a low certification costs (Philppot and Dietsch 2003, Perfecto et al. 2005 and Steffan-Dewenter et al. 2007). Moreover, because farmers in southern Cameroon have long tradition of managing forest trees in their farm yards (Duguma et al. 2001), they showed a preference for low-shade TFGs as to open plantations, suggesting that even lower incentives could encourage the preservation of shaded TFGs. Despite the high yields of intensified TFGs, their profitability depends upon a high cocoa price on the international market and therefore is economically risky for owners because the high production costs do not secure high revenues.

Certification programs for shade-grown cocoa in Mesoamerica (Dietsch et al. 2004; Perfecto et al. 2005 and Gordon et al. 2007) is well developed and the market available 
(Messer et al. 2000), suggesting that such mechanism is also possible for cocoa agroforestry. To promote certification program in cocoa, shaded cocoa agroforestry systems need to be encouraged; farmers need to be educated on the ecosystem services provided by shaded systems; the market and consumers should appreciate more environmentally-friendly products and low intensity systems need to be subsidized. This approach could help guide management decision by both farmers and certifications agencies to promote the conservation value of TFGs of tropical biodiversity and sources of valuable ecosystem services.

\section{Acknowledgements}

Financial assistance was provided by the University of Goettingen (IPAG "International $\mathrm{PhD}$ Programme in Agricultural Sciences in Goettingen") and "Le Ministère Français de la Cooperation" Through the SCCS project. We thank the staff of the Laboratory of Entomology at the "Institut de la Recherche Agricole pour le Développement" (IRAD) in Nkolbisson, Cameroon: M. Djalla, AD. Missoup, M. Mbenoum, V. Ondoua, J. Nzomo, JC. Mongo, N. Essomo, C. Ngoum Esse and V. Koumpia and smallholder cocoa farmers for help in the field.

\section{References}

Armbrecht I., Perfecto I. (2003) Litter-twig dwelling ant species richness and predation potential within a forest fragment and neighboring coffee plantations of contrasting habitat quality in Mexico. Agric. Ecosyst. Environ. 97, 107-115.

Bobo S.K., Waltert M., Sainge M.N., Njokagbor J., Fermon H., Mühlenberg M. (2006) From forest to farmland: species richness patterns of trees and understorey plants along a gradient of forest conversion in Southwestern Cameroon. Biodiv. and Conserv. 15:40974117.

Carrière M.S., Letourmy P. and Mckey D.B. (2002) Effects of remnant trees in fallows on diversity and structure of forest regrowth in a slash-and-nurn agricultural system in southern Cameroon. J. Trop. Ecol. 18: 375 - 396. 
Coulibaly O., Mbila D., Sonwa D.J., Adesina A., Bakala J. (2002) Responding to economic crisis in sub-saharan Africa: New farmer-developed pest management strategies in cocoa-based plantations in Southern Cameroon. Int. Pest Manage. Rev. 7, 165-172.

Delabie J.H.C., Fisher B.L., Majer J.D. and Wright, I.W. (2000) Sampling effort and choice of methods. In: ants: Standard methods for measuring and monitoring biodiversity (eds Agosti, D., Majer, JD., Alonso, LE. And Schultz, TR.) pp 145-154. Smithsonian Institution Press, Washington.

Dietsch T., Phipott S.M., Rice R., Greenberg R., Bichier P. (2004) Policy alternatives for conservation in coffee landscapes. Science 303, 625.

Donald P.F. (2004) Biodiversity impacts of some agricultural commodities production systems. Conserv. Biol. 18, $17-37$.

Duffy J.E. (2002) Biodiversity and ecosystem function: The consumer connection. Oikos, 99: $201-219$.

Duguma, B., Gockowski, J. and Bakala, J. (2001) Smallholder cacao (Theobroma cacao Linn.) cultivation in agroforestry systems of West and Central Africa: Challenges and opportunities. Agroforest. Syst. 51: $177-188$.

Gordon C., Manson R., Sundberg J. and Cruz Angón A. (2007) Biodiversity, profitability, and vegetation structure in a Mexican coffe agroecosystem. Agr. Ecosyst. Environ. 118: 256 - 266.

Green, R.E., Cornell, J.S., Scharlemann, J.P.W., Balmford A. (2005) Farming and the fate of wild nature. Science 307, 550 - 555. 
Greenberg R. Bichier P. and Cruz Angón A. (2000) The conservation value for birds of cacao plantations with diverse planted shade in Tabasca, Mexico. Anim. Conserv. 3: 105 -112 .

Greenberg, R. (1998) Biodiversity in the cacao agroecosystem: Shade management and Landscape consideration. Proceeding of the Smithsonian Migratory Bird Centre cacao conference:http://nationalzoo.si.edu/ConservationAndScience/MigratoryBirds/Research/ Cacao/greenberg.cfm (accessed April 2007)

ICCO (2005) International cocoa organization annual report 2004/2005. 40 pp.

Ives A.R., Klug J.L. and Gross K. (2000) Stability and species richness in complex communities. Ecol. Letters, 3: 399 - 411.

Klein A., Steffan-Dewenter I., Buchori D., \& Tscharntke T. (2002a) Effects of land-use intensity in tropical agroforstry systems on coffee flower-visiting and trap-nesting bees and wasps. Conserv. Biol. 16: 1003-1014.

Klein A.M., Steffan-Dewenter I., Tscharntke T. (2006) Rainforest promotes trophic interactions and diversity of trap-nesting Hymenoptera in adjacent agroforestry. J. Anim. Ecol. 75, $315-323$.

Klein A.M., Steffan-Dewenter I., Tscharntke T. (2003a) Fruit set of highland coffee increases with the diversity of pollinating bees. Proc. R. Soc. Lond., Ser. B 270, 955-961.

Klein A.M., Steffan-Dewenter I., Tscharntke T. (2003b) Pollination of Coffea canephora in relation to local and regional agroforestry management. J. Appl. Ecol. 40, 837-845.

Klein AM., Steffan-Dewenter, I. and Tscharntke T. (2002b). Predator-prey ratios on cocoa along a land-use gradient in Indonesia. Biodiv. and Conserv. 11. 683-693. 
Messer K.D., Kotchen M.J., Moore M.R. (2000) Can shade-grown coffee help conserve tropical biodiversity? A market perspective. Endangered Species Update 17, 125-131.

O’Brien T.J., Kinnaird M.F. (2003) Caffeine and conservation. Science 300, 587.

Peeters P.J., Read J. and Sanson G.D. (2001) Variation in the guilt composition of herbivorous insect assemblages among co-occuring plant species. Austral Ecol. 26, 385399.

Perfecto I., Rice R.A., Greenberg R. and Voort M.E. (1996) Shade coffee: a disappearing refuge for biodiversity. Shade coffee plantations can contain as much biodiversity as forest habitats. BioScience. 46. 598-608.

Perfecto I., Vandermeer J., (1996) Microclimatic changes and the indirect loss of ant diversity in a tropical agroecosystem. Oecologia 108, 577- 582.

Perfecto I., Vandermeer J., Mas A., and Soto Pinto L. (2005) Biodiversity, yield, and shade coffee certification. Ecol. Econ. 54: 435- 446.

Perfecto I., Vandermeer J.H., Bautista G.L., Ibarra Nuñez G., Greenberg R., Bichier P., and Langridge S. (2004) Greater predation in shaded coffee farms: The role of resident neotropical birds. Ecology 85: 2677 - 2681.

Philpott S. and Armbrecht I. (2006) Biodiversity in tropical agroforests and the ecological role of ants and ant diversity in predatory function. Ecol. Entomol. 31: 369 - 377.

Philpott S. M., Perfecto I. amd Vandermeer J. (2006) Effects of management intensity and season on arboreal ant diversity and abundance in coffee agroecosystems. Biodivers. Conserv. 15: $139-155$. 
Philpott S.M. and Dietsch T. (2003) Coffee and Conservation: a global context and the value of farmer involvement. Conserv. Biol. 17, $1844-1849$.

Pimentel, D. Wilson, C. McCullum, C.M. Huang, R. Dwen, P. Flack, J. Tran, Q. Saltman, T. Cliff, B. (1997) Economic and environmental benefits of biodiversity. Bioscience 47, $747-757$.

Power, A.G. and Flecker, A.S. (1996) Agroecosystems and Biodiversity. Proceeding of the Smithsonian Migratory Bird Centre cacao conference. Available from http://nationalzoo.si.edu/ConservationAndScience/MigratoryBirds/Research/Cacao/powe $\underline{\text { r.cfm }}$ (accessed April 2007)

Rappole J.H., King D.I., Vega Rivera J.H. (2003b) Coffee and conservation: III. Reply to Philpott and Dietsch. Conserv. Biol. 17, 1847- 1849.

Rappole J.H., King, D.I., Vega Rivera J.H. (2003a) Coffee and conservation. Conserv. Biol. 17, 334- 336 .

Reitsma R., Parrish J.D. and McLarney W. (2001) The role of cocoa plantations in maintaining forest avian diversity in southeastern Costa Rica. Agroforest. Syst. 53: 185 193.

Ribas C.R., Schoereder J.H., Pic M. and Soares S.M. (2003) Tree heterogeneity, resource availability, and larger scale processes regulating arboreal ant species richness. Austral Ecology. 28, 305-314.

Romero-Alvarado Y., Soto-Pinto L., García-Barrios L., Barrera-Gaytán J.F. (2002)

Coffee yields and soil nutrients under the shades of Inga sp. vs. multiple species in Chiapas, Mexico. Agrofor. Syst. 54, 215-224.

Room PM. (1971) The relative distribution of ant species in Ghana's cocoa farms. J. of Anim. Ecol. 40, 735-751. 
Schroth G., da Fonseca G.A.B., Harvey C.A., Gascon C., Vasconcelos H.L., Izac A-M.N. (2004) Agroforestry and Biodiversity Conservation in Tropical Landscapes. Island, Washington, DC.

Soto-Pinto L., Perfecto I., Caballero-Nieto J. (2002) Shade over coffee: its effects on berry borer, leaf rust and spontaneous herbs in Chiapas, Mexico. Agrofor. Syst. 55, 3745.

Sperber C.F., Nakayama K., Valverde M.J. and Neves F.S. (2004) Tree species richness and diversity affect parasitoid diversity in cacao agroforestry. Basic and Appl. Ecol. 5, 241-151.

Steffan-Dewenter I., Kessler M., Barkmann J, Bos M., Buchori D., Erasmi S., Faust H., Gerold G., Glenk K., Gradstein R.S., Guhardja E., Harteveld M., Hertel D., Höhn P., Kappas M., Köhler S., Leuschner C., Maertens M., Marggraf R., Migge-Kleian S., Mogea J., Pitopang R., Schaefer M., Schwarze S., Sporn G.S., Steingrebe A., Tjitrosoedirdjo S.S., Tjitrosoemito S., Twele A., Weber R., Woltmann L., Zeller M., Tscharntke T. (2007) Tradeoffs between income, biodiversity, and ecosystem functioning during tropical rainforest conversion and agroforestry intensification. PNAS 104: 4973 4978

Vandermeer J. (1995) The ecological basis of alternative agriculture. Ann. Rev. Ecol. System. 26, 201-224.

Wilson E.O. (1959) Some ecological characteristics of ants in New Guinean rain forests. Ecology. 40, 437-447.

Zapfack L., Engwald S., Sonke B., Achoundong G., and Birang M. (2002) The impact of land conversion on plant biodiversity in the forest zone of Cameroon. Biodivers. Conserv. 11: $2047-2061$. 


\section{List of Figures}

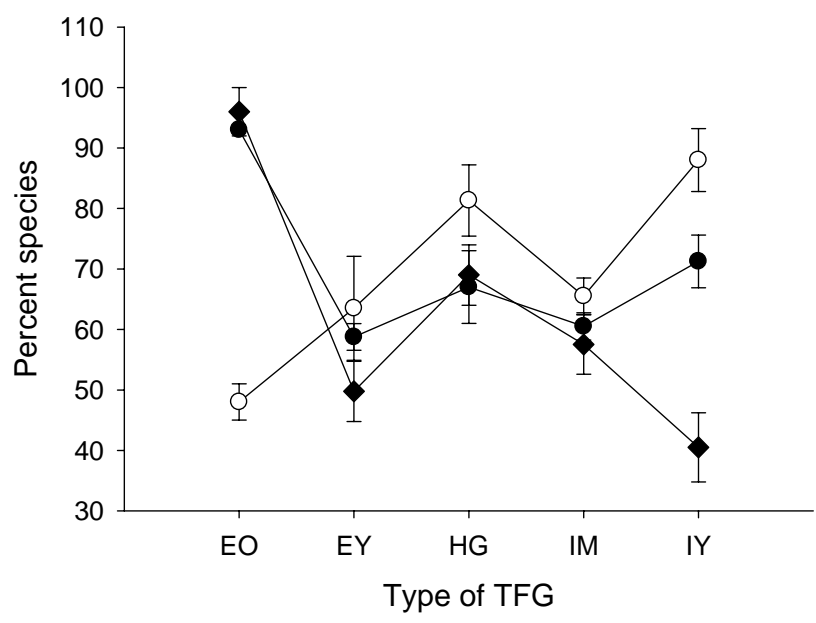

Figure 1. Effect of land-use intensity on percent ant species richness (close circle), ant abundance (open circle) and tree species richness (close diamond) in traditional cocoa forest gardens of southern Cameroon. EO - Extensive manage old cocoa forest gardens; EY - Extensive manage young cocoa forest gardens; HG - Home garden cocoa forests; IM - Intensive manage mature cocoa forest gardens; IY - Intensive manage young cocoa forest gardens
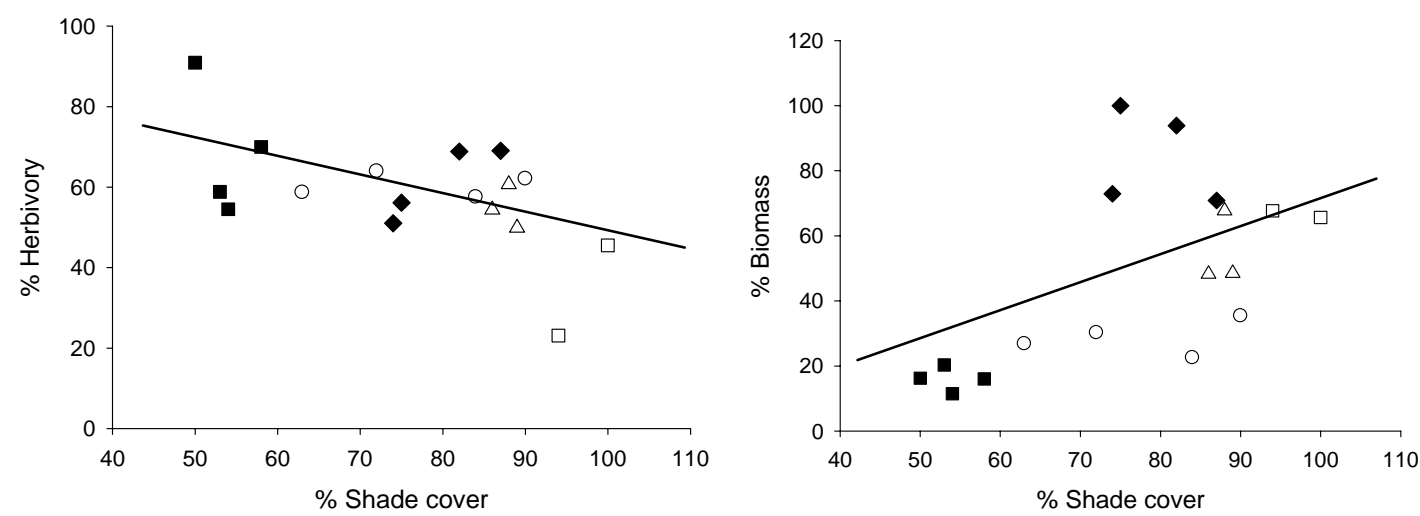

Figure 2. Ecosystem function expressed in term of insects herbivory (pod loss to Cocoa pod borers and mirids ( $S$. singularis) $\left(R^{2}=0.28, R=0.53, F=5.85, p=0.03, \mathrm{Y}=111.67-\right.$ $0.60 \mathrm{x})$ and above ground vegetation biomass $\left(R^{2}=0.36, R=0.60, F=8.52, p=0.011\right.$, $y=1.08 x-34.87$ ) along a gradient of canopy cover. Open square represents extensive old systems, open circle represents extensive young systems, triangle up represents home garden systems, close diamond represents intensive old systems and close square represents intensive young systems. 


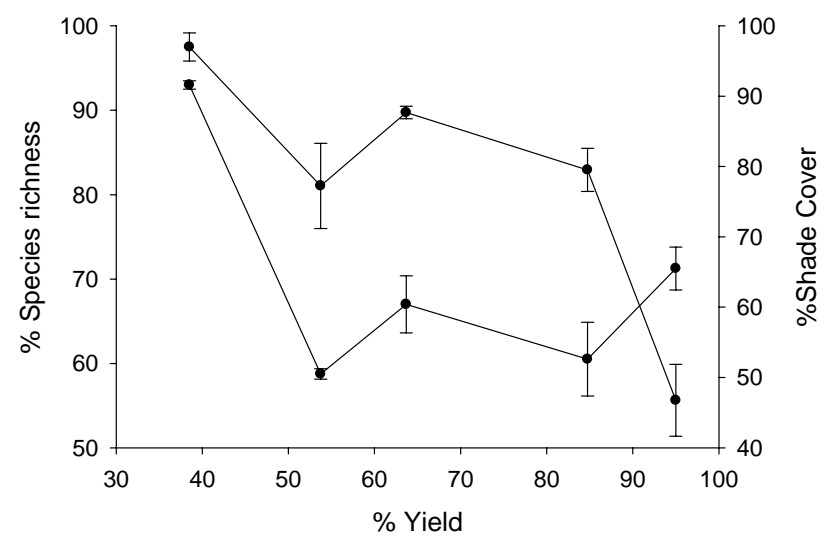

Figure 3. Relationship between percent species richness of ants and the percent of yield based on percent shade cover for 5 management systems in southern Cameroon. The percent of species richness is based on the number of species found in cocoa plantations. The percent yield is based on the maximum yield recorded within a range of shade cover.

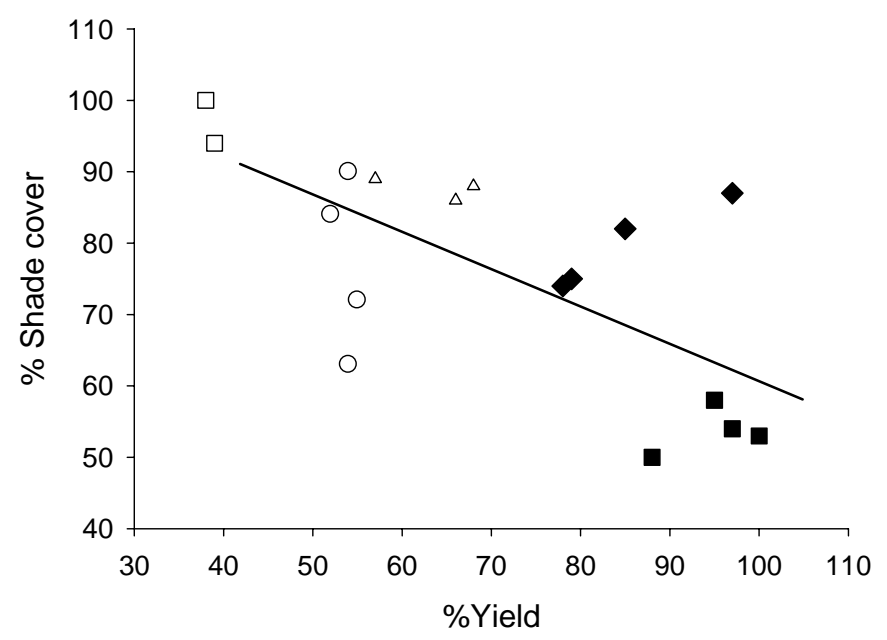

Figure 4. Relationship between percent shade cover and percent yield in cocoa plantations in southern Cameroon $(F=11.77, p=0.004, \mathrm{y}=118.19-0.61 \mathrm{x}, \mathrm{r}=0.66$, $R^{2}=0.44, \mathrm{n}=17$ ). Open square represents extensive old systems, open circle represents extensive young systems, triangle up represents home garden systems, close diamond represents intensive old systems and close square represents intensive young systems. 


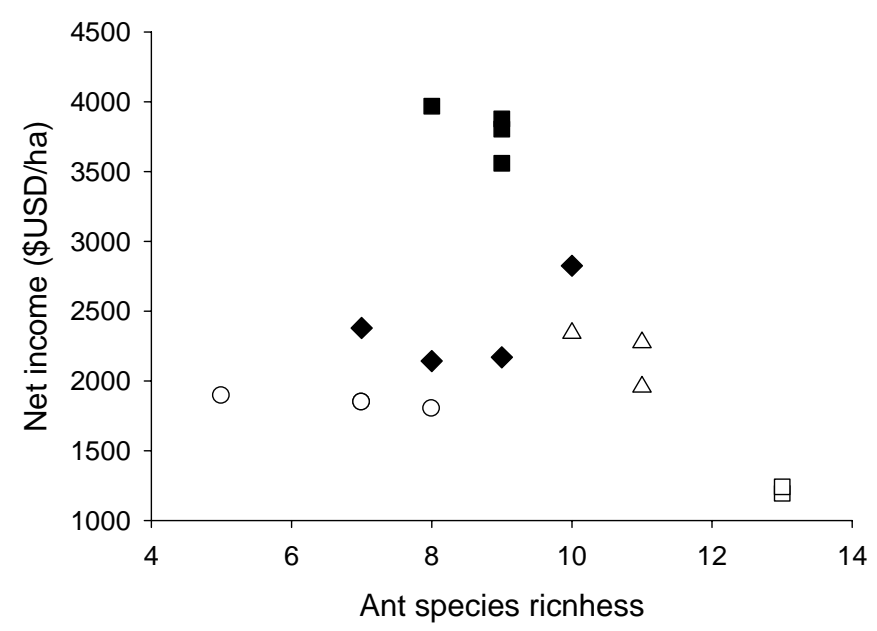

Figure 5. Relationship between cocoa plantation profitability and the ant species richness. Net income calculation assumes price of $\$ 1.5 \mathrm{p} / \mathrm{kg}$ of cocoa beans. Open square represents extensive old systems, open circle represents extensive young systems, triangle up represents home garden systems, close diamond represents intensive old systems and close square represents intensive young systems.

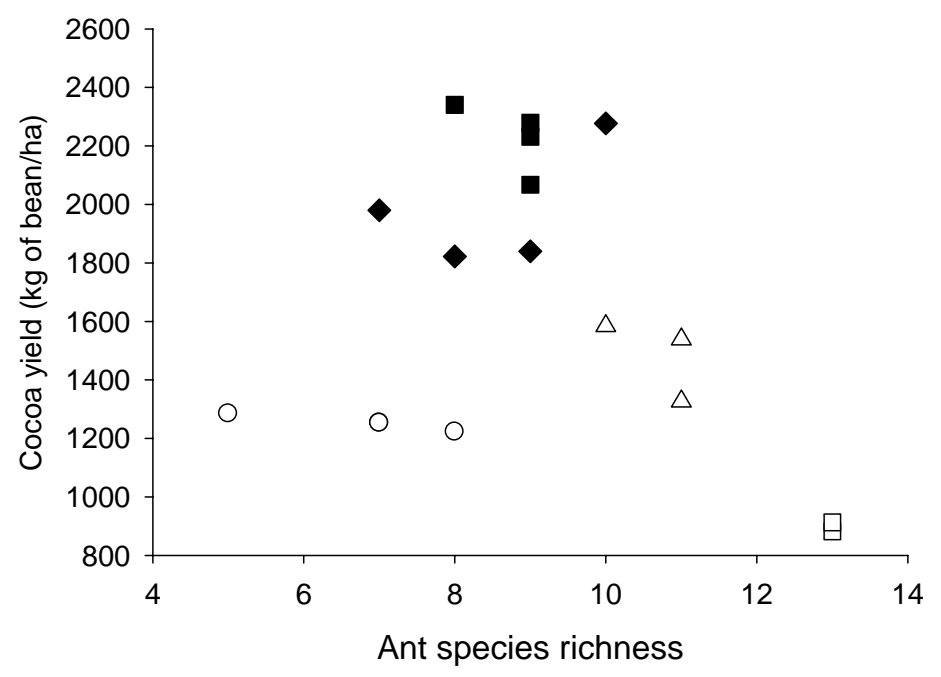

Figure 6. Relationship between cocoa yield and the ant species richness. Cocoa yield is expressed as kilogram of cocoa beans produced per hectare. Open square represents extensive old systems, open circle represents extensive young systems, triangle up represents home garden systems, close diamond represents intensive old systems and close square represents intensive young systems. 


\section{List of Tables}

Table 1. Correlation coefficients between and among ant and vegetation variables (see text for description of variables)

\begin{tabular}{cccccc}
\hline & $\begin{array}{c}\text { Tree } \\
\text { species }\end{array}$ & $\begin{array}{c}\text { Tree } \\
\text { density }\end{array}$ & $\begin{array}{c}\text { Canopy } \\
\text { height }\end{array}$ & $\begin{array}{c}\text { Percent } \\
\text { shade }\end{array}$ & $\begin{array}{c}\text { Ant } \\
\text { species }\end{array}$ \\
\hline Tree density & 0.67 & & & & \\
Canopy height & 0.51 & 0.38 & & & \\
Percent shade & 0.69 & 0.57 & 0.56 & & \\
Ant species & 0.46 & 0.74 & 0.39 & 0.34 & 0.74 \\
Ant abundance & 0.29 & 0.23 & 0.10 & 0.08 & 0 \\
\hline
\end{tabular}

Table 2. Multiple linear regression models of relationship between vegetation variables and the species richness and abundance of ants.

\begin{tabular}{|c|c|c|c|}
\hline & Coefficient & $\mathrm{t}$ & $p(t)$ \\
\hline \multicolumn{4}{|c|}{ Ant species richness model (adjusted $r^{2}=0.25, p(F)<0.001$} \\
\hline Tree richness & 0.60 & 3.60 & 0.003 \\
\hline Tree density & 0.03 & 4.35 & 0.0006 \\
\hline
\end{tabular}


Table 3. Net income per hectare (\$USD) based on cocoa price fluctuation in traditional cocoa forest gardens in southern Cameroon

\begin{tabular}{ccccc}
\hline & Price 1 & Price 2 & Price 3 & Price 4 \\
\hline EO & 858 & 1218 & 1935 & 3012 \\
EY & 1346 & 1847 & 2849 & 4354 \\
HG & 1598 & 2191 & 3378 & 5158 \\
IM & 1587 & 2379 & 3963 & 6338 \\
IY & 2910 & 3802 & 5585 & 8261 \\
\hline
\end{tabular}

EO - Extensive manage old cocoa forest gardens; EY - Extensive manage young cocoa forest gardens; HG - Home garden cocoa forests; IM - Intensive manage mature cocoa forest gardens; IY - Intensive manage young cocoa forest gardens. Data are presented in terms of net FCFA generated per hectare per year. Prices are calculated base on realistic market price situations expressed in FCFA per kilogram of unprocessed cocoa beans purchase to farmers as follows (and see text): price $1=\$ 1.1 \mathrm{p} / \mathrm{kg}$; price $2=\$ 1.5 \mathrm{p} / \mathrm{kg}$; price $3=\$ 2.3 \mathrm{p} / \mathrm{kg}$ and price $4=3.5 \mathrm{p} / \mathrm{kg} .(1 \$ \mathrm{USD}=500 \mathrm{FCFA})$ 


\section{Discussion}

Traditional cocoa forest gardens, as formerly observed in southern Cameroon, with high floristic and fauna diversity, are considered the most environmentally sound form of cocoa production. However, these rich diversity systems are currently threatened by intensification through partial or complete removal of shade trees, resulting in increasing pests and disease outbreaks.

Results from the survey of 400 cocoa farmers within the selected TFGs show that management practices in the five groups of traditional cocoa forest gardens are influenced by socio-economic, technical or biological and environmental parameters, with negative impacts on productivity. In response to that farmers have developed local cocoa varieties and apply indigenous/traditional methods of pests and diseases control. These include mainly the use of botanicals (crude plant extracts). We also observed that Cocoa as a cash crop is clearly integrated into the rural economies of women in southern Cameroon in different ways. However, their position to land is highly variable and contentious. Most of them gain rights to land through their relationships with men, as wives or kin, or have made use of anonymous land markets to create new access to land and in some cases, new rights. However, strengthening women property rights will reduce deforestation and contribute to the sustainable management of resources even under current social and ecological changes and can have a significant and positive effect on reducing hunger and poverty. Our survey revealed that land tenure and resource rights play an important role in how cocoa farms are managed, including the retention and planting of non-cocoa tree species, and the management and use of biodiversity.

We were able to document that management, as practiced in traditional cocoa forest gardens in southern Cameroon, follows a gradient of intensification from extensive cocoa forest gardens with high floristic diversity to intensive ones. This strongly impacts ants and plant diversity, plant biomass and, to some extend, carbon storage with possible negative consequences on biodiversity (Kottto-Same et al. 1997; Greenberg et al. 2000; Reitsma et al. 2001). However, farmers in intensive systems are concerned about the importance of tree as shade but lack appropriate technologies in tree domestication or are 
not able to identify appropriate trees for shade. We thus suggest food diversification of both crop and non-crop commodities such as non-timber forest products and fruit tree species in TFGs (Zapfack et al. 2002; Bobo et al. 2006; Schroth and Harvey 2007, Sonwa et al. 2007). In advance to our studies and with regard to the role of biodiversity in biological control of the main cocoa pests and diseases we reported that ecosystem functioning showed significant responses to shade cover reductions in TFGs for herbivory and above ground plant biomass. We suggest that the transition from extensive systems with heavy shade to intensive ones with reduced or open shade is likely to result in a significant decline in ecosystem functioning with more regular pest outbreaks as well as other ecosystem services as a consequence. Our results support the insurance hypothesis, which states that biodiversity insures ecosystems against loss in their functioning when environmental conditions change (Ives et al. 2000; Perfecto et al. 2004; Philpott and Armbrecht 2006) and suggest an important potential role for ants in controlling outbreaks in diverse cocoa plantations or in diverse tropical agroforests. We were able to demonstrate for the first time that increasing biodiversity, measured as ant and plant species richness will enhance biological control of the main cocoa pests (mirid bugs and cocoa pod borers). However, we found that current management regimes in TFGs manipulate ant species richness and evenness at tree level, thus negatively affecting arboreal ant richness, resulting in increasing black pod incidence and decreasing productivity. We provide for the first time evidence that ants, although generally regarded as beneficial in cocoa plantations (Way and Khoo 1992, Philpott and Armbrecht 2006) do increase the incidence of black pod disease, provided a low diversity of ant species is present on the cocoa trees. However, if ant communities became more diverse and the habitats occupied by the ants more restricted on these trees, the incidence of BPD decreased. Given the outstanding impact of the ants, we downgraded the importance of factors such as temperature and relative humidity, typically regarded of superior importance for disease outbreaks, which in this scenario did not directly affect black pod incidence. Consequently, by keeping a high diversity of ants on their trees, cocoa farmers will be able to maintain a lower incidence of black pod disease. We conclude that enhanced biodiversity can also help in reducing the incidence of black pod disease caused by $P$. megakarya. Therefore modifying the functional diversity and composition through 
modifications in the habitat and land-use change will have large impacts on agroecosystem processes.

In advance of our studies there was a popular notion that the mirid bug $S$. singularis (SS) is the vector of BPD. However, we showed for the first time that the interactions between mirid bugs (SS) and P. megakarya appeared to be mutually exclusive in time and space, independent of different management regimes. Thus, we hypothesise that the incidence of BPD stimulates not yet known cocoa plant defense mechanisms that in turn influence the host plant selection behaviour of SS. These findings release SS from the popular notion of being a vector of BPD. The study of the distribution of SS in cocoa plantations using four regression models (Taylor's power law, Iwao's patchiness regression, the Nachman model and the Non Binomial distribution model (NBD)) revealed that Taylor's power law better fitted the data than Iwao's and Nachman models. However, the non binomial distribution model was appropriate for studying SS distribution based on comparison of NBD basis and Nachman's models. The aggregation indices (slopes, b and $\beta$ ) of Taylor's power law and Iwao's patchiness regression were all significantly $>1(P<0.001)$, indicating an aggregated dispersion distribution of SS with a single individual as a basic distribution component (Iwao 1970). We develop and recommend a sequential sampling plan, based on counts of mirid bugs on cocoa, for accurate decisions based on mean numbers.

Our findings, unlike those found by Perfecto et al. (2005) on coffee, report a linear relationship between shade and yield and describe a concave set of relationship between yield and ant species richness in TFGs. The relationship between yield and species richness is concave for organisms that are sensitive to shade and convex for resistant organisms (Perfecto et al. 2005). This implies that there is a possibility to establish effective premiums for shade cocoa for the purpose of conserving biodiversity. We provide a direct measurable assessment of the biodiversity-net income relationship in cocoa. Our models indicate that there is not a simple trade-off between biodiversity and net income. Therefore, high biodiverse TFGs are not necessarily less profitable than lowbiodiverse ones. However, to improve income and livelihoods of smallholders cocoa farmers, economic incentives are required to prevent further intensification beyond ecologically acceptable shade cover. Incentives may be in the form of organic and fair 
trade certification where farmers receive directly high price premiums or have low certification costs (Philppot and Dietsch 2003, Perfecto et al. 2005 and Steffan-Dewenter et al. 2007). Moreover, because farmers in southern Cameroon have long a tradition of managing forest trees in their farm yards (Duguma et al. 2001), they showed a preference for low-shade TFGs as to open plantations, suggesting that even lower incentives could encourage the preservation of shaded TFGs. To promote certification programs in cocoa, shaded cocoa agroforestry systems need to be encouraged; farmers need to be educated on the ecosystem services provided by shaded systems; the market and consumers should appreciate more environmentally-friendly products and low intensity systems need to be subsidized. This approach could help guide management decision by both farmers and certifications agencies to promote the conservation value of TFGs of tropical biodiversity and sources of valuable ecosystem services.

For policy implications to achieve ecological, social and economic sustainability in cocoa productions in southern Cameroon, we suggest the following:

1. On farm diversification, specifically the diversification of crops, non-crops and income may simultaneously benefit biodiversity and the economic security of smallholder cocoa farmers.

2. Greater focus on determining effective economic incentives for maintaining shade in cocoa production. i.e. premium prices for "High quality" cocoa grown under shade or fair trade.

3. Special efforts to be implemented to protect extensive TFGs from intensification and simplification of the shade canopy and from conversion to other land uses.

4. Promotion of indigenous/traditional methods of pests and diseases control.

5. Research on gender inequality and income-based pro-poor growth measures in cocoa productions 


\section{References}

Bayard, V., Chamorro, F., Motta, J. and Hollenberg, N.K. (2007) Does Flavanol Intake Influence Mortality from Nitric Oxide-Dependent Processes? Ischemic Heart Disease, Stroke, Diabetes Mellitus, and Cancer in Panama. 4(1):53-58.

Bobo S.K., Waltert M., Sainge M.N., Njokagbor J., Fermon H., Mühlenberg M. (2006)

From forest to farmland: species richness patterns of trees and understorey plants along a gradient of forest conversion in Southwestern Cameroon. Biodiv. and Conserv. 15:40974117.

Clay J. (2004) World agriculture and the environment. Island Press, Washington.

Dahlquist, R.M. Whelan, M.P. Winowiecki, L., Polidoro, B., Candela, S., Harvey, C.A., Wulfhorst, J.D. McDaniel, P.A. and Bosque-Perez, N.A. (2007) Incorporating livelihoods in biodiversity conservation: a case study of cacao agroforestry systems in Talamanca, Costa Rica. Biodiv. Conserv. 16: 2311 - 2333.

Delabie J., Jahyny, B., do Nacimento, I.C., Cléa S.F.M., Lacau, S., Campiolo, S. Philpott, S. and Leponce, M. (2007) Contribution of cocoa plantations to the conservation of native ants (Insecta: Hymenoptera: Formicidae) with a special emphasis on the Atlantic Forest fauna of southern Bahia, Brazil. Biodiv. Conserv. 16: 2359 - 2384.

Dietsch T., Phipott S.M., Rice R., Greenberg R., Bichier P. (2004) Policy alternatives for conservation in coffee landscapes. Science 303, 625.

Donald P.F. (2004) Biodiversity impacts of some agricultural commodities production systems. Conserv. Biol. 18, $17-37$.

Duguma, B., Gockowski, J. and Bakala, J. (2001) Smallholder cacao (Theobroma cacao Linn.) cultivation in agroforestry systems of West and Central Africa: Challenges and opportunities. Agroforest. Syst. 51: $177-188$. 
Efombagn, M.I.B., Sounigo, O., Nyassé, S., Manzanares-Dauleux, M., Cilas, C. Eskes M.A.B. and Kolesnikova-Allen (2006) Genetic diversity in cocoa germplasm of southern Cameroon revealed by simple sequences repeat (SSRS) markers. Afric. J. of Biotec. 5 (16): 1441-1449.

Faria, D., Laps, R.R., Baumgarten, J. and Cetra M. (2206) Bat and bird assemblages from forests and shade cacao plantations in two contrasting landscapes in the Atlantic Forest of southern Bahia, Brazil. Biodiv. Conserv. 15: 587 - 612 .

Franzen, M. and Mulder, B.M. (2007) Ecological, economic and social perspectives on cocoa production worldwide. Biodiv. Conserv. DOI 10.1007/s10531-007-9183-5 (Review Paper).

Gockowski J. and Ndoumbe M. (2004) The adoption of intensive monocrop horticulture in southern Cameroon. Agric Econ 30:195-202.

Gockowski J. J. and Dury S. (1999) The economics of cocoa-fruit agroforests in Southern Cameroon. In: Jiménez $\mathrm{F}$ and Beer $\mathrm{J}$ (eds) Multi-strata agroforestry systems with perennial crops. Turrialba, CATIE, pp $239-241$.

Gordon C., Manson R., Sundberg J. and Cruz Angón A. (2007) Biodiversity, profitability, and vegetation structure in a Mexican coffe agroecosystem. Agr. Ecosyst. Environ. 118: 256 - 266.

Green, R.E., Cornell, J.S., Scharlemann, J.P.W., Balmford A. (2005) Farming and the fate of wild nature. Science 307, 550 - 555.

Greenberg R. Bichier P. and Cruz Angón A. (2000) The conservation value for birds of cacao plantations with diverse planted shade in Tabasca, Mexico. Anim. Conserv. 3: 105 -112 . 
Greenberg, R. (1998) Biodiversity in the cacao agroecosystem: Shade management and Landscape consideration. Proceeding of the Smithsonian Migratory Bird Centre cacao conference:http://nationalzoo.si.edu/ConservationAndScience/MigratoryBirds/Research/ Cacao/greenberg.cfm (accessed April 2007).

Gregory, P.H., Griffin, M.J.; Maddison, A.C., Ward, M.R. (1985) Cocoa Growers Bull. 35: $2-8$.

Guyer J.I. (1984) Family and farm in Southern Cameroon. African Research Studies No 15. Boston University African Studies Center, Boston.

ICCO (2006) International cocoa organization annual report 2005/2006. 43 pp. http://www.icco.org/pdf/An_report/anrep0506english.pdf (accessed September 2007).

Ives A.R., Klug J.L. and Gross K. (2000) Stability and species richness in complex communities. Ecol. Letters, 3: 399 - 411.

Iwao S. (1970) Problems in spatial distribution in animal population ecology. In: Patil, G.P. (eds.) Random counts in models and structures, 1. Pennsylvania State University Press, University Park. 268 pp.

Klein A.M., Steffan-Dewenter I., Tscharntke T. (2003a) Fruit set of highland coffee increases with the diversity of pollinating bees. Proc. R. Soc. Lond., Ser. B 270, 955-961.

Klein A.M., Steffan-Dewenter I., Tscharntke T. (2003b) Pollination of Coffea canephora in relation to local and regional agroforestry management. J. Appl. Ecol. 40, 837-845.

Kotto-Same J., Woomer P.L., Moukam A. and Zapfack L. (1997) Carbon dynamics in slash-and-burn agriculture and land use alternatives of the humid forest zone in Cameroon. Agr. Ecosys. Environ. 65: 245 - 256.

Laird, S. A., Leke Awung, G. and Lysinge, R. J. (2007) Cocoa farms in the Mount Cameroon region: biological and cultural diversity in local livelihoods. Biodiv. Conserv. 16: $2401-2427$. 
Lass T. (2004) Balancing cocoa production and consumption. In: Flood J, Murphy R (eds) Cocoa futures - a source book on some important issues facing the cocoa industry. CABI-FEDERACAFE, USDA, Chinchina, Colombia, pp 8-15.

Lee, K.W., Kim, J.Y., Lee, J.H. and Lee Y.C. (2007) Cocoa Has More Phenolic Phytochemicals and a Higher Antioxidant Capacity than Teas and Red Wine. J. Agric. Food Chem. 51: 7292-7295.

Merijn M. B., Steffan-Dewenter, I. and Tscharntke T. (2007) The contribution of cacao agroforests to the conservation of lower canopy ant and beetle diversity in Indonesia. Biodiv. Conserv. 16: $2429-2444$.

Mink, P.J., Scrafford, G.C., Barraj, M.L., Harnack, L., Hong, C.P., Nettleton, A.J. and Jacobs, R.D. (2007) Flavonoid intake and cardiovascular disease mortality: a prospective study in postmenopausal women. Am. J. Clin. Nutr. 85:895-909.

Moguel P., \& Toledo VM. (1999) Biodiversity conservations in traditional coffee systems of Mexico. Conserv. Biol. 13: 11-22.

Mpé, J. M. (2002) Integrated management of cocoa mirids in Cameroon. In: Vos, J. and Neuenschwander, P. (eds). West Africa regional cocoa IPM workshop proceeding, Cplpress, pp. 39.

Nya Ngatchou J. (1981) Etat d'avancement des travaux de génétique et d'amélioration du cacaoyer au Cameroun. VIIth Intern. Cocoa Rech. Conf., Douala, Cameroon. pp. 507511.

Nyasse, S. (1992) Structure d'une population de Phytophthora sp. Des cacaoyères camerounaises atteintes de pourriture brune. DRU Sciences agronomiques, Institut National Polytechnique de Toulouse.

O’Brien T.J., Kinnaird M.F. (2003) Caffeine and conservation. Science 300, 587. 
Perfecto I., Rice R.A., Greenberg R. and Voort M.E. (1996) Shade coffee: a disappearing refuge for biodiversity. Shade coffee plantations can contain as much biodiversity as forest habitats. BioScience. $\underline{46}$. 598-608.

Perfecto I., Vandermeer J., Mas A., and Soto Pinto L. (2005) Biodiversity, yield, and shade coffee certification. Ecol. Econ. 54: 435- 446.

Perfecto I., Vandermeer J.H., Bautista G.L., Ibarra Nuñez G., Greenberg R., Bichier P., and Langridge S. (2004) Greater predation in shaded coffee farms: The role of resident neotropical birds. Ecology 85: 2677 - 2681.

Philpott S. and Armbrecht I. (2006) Biodiversity in tropical agroforests and the ecological role of ants and ant diversity in predatory function. Ecol. Entomol. 31: $369-377$.

Philpott S. M., Perfecto I. amd Vandermeer J. (2006) Effects of management intensity and season on arboreal ant diversity and abundance in coffee agroecosystems. Biodivers. Conserv. 15: $139-155$.

Philpott S.M. and Dietsch T. (2003) Coffee and Conservation: a global context and the value of farmer involvement. Conserv. Biol. 17, $1844-1849$.

Pimentel, D. Wilson, C. McCullum, C.M. Huang, R. Dwen, P. Flack, J. Tran, Q. Saltman, T. Cliff, B. (1997) Economic and environmental benefits of biodiversity. Bioscience 47, $747-757$.

Rappole J.H., King D.I., Vega Rivera J.H. (2003b) Coffee and conservation: III. Reply to Philpott and Dietsch. Conserv. Biol. 17, 1847- 1849.

Rappole J.H., King, D.I., Vega Rivera J.H. (2003a) Coffee and conservation. Conserv. Biol. 17, 334- 336 .

Reitsma R., Parrish J.D. and McLarney W. (2001) The role of cocoa plantations in maintaining forest avian diversity in southeastern Costa Rica. Agroforest. Syst. 53: 185 193. 
Rice R, Greenberg R (2000) Cacao cultivation and the conservation of biological diversity. Ambio 29:167-173.

Romero-Alvarado Y., Soto-Pinto L., García-Barrios L., Barrera-Gaytán J.F. (2002)

Coffee yields and soil nutrients under the shades of Inga sp. vs. multiple species in Chiapas, Mexico. Agrofor. Syst. 54, 215-224.

Schroth G., Harvey C., Vincent G. (2004) Complex agroforests: their structure, diversity, and potential role in landscape conservation. In: Schroth G., da Fonseca G.A.B., Harvey C.A., Gascon C., Vasconcelos H.L., Izac, A.M.N. (eds) Agroforestry and biodiversity conservation in tropical landscapes. Island Press, Washington, D.C., pp 227-260.

Schroth, G. and Harvey, C.A. (2007) Biodiversity conservation in cocoa production landscapes: an overview. Biodiv. Conserv. 16:2237 - 2244.

Sonwa D. J. (2004) Biomass management and diversification within cocoa agroforest in the humid forest zone of Southern Cameroon. PhD thesis. Faculty of Agriculture. University of Bonn. Germany. Cuvillier Verlag, Goettingen. 112 pp.

Sonwa, D. J., Nkongmeneck, B. A., Weise, S. F., Tchatat, M., Adesina, A.A. and Jansens, M. J. J. (2007) Diversity of plants in cocoa agroforests in the humid forest zone of Southern Cameroon. Biodiv. Conserv. 16: 2485 - 2400.

Sonwa, D.J., O. Coulibaly, A. Adesina, S.F. Weise and M. Tchatat (2002) Integrated pest Management in cocoa agroforests in Southern Cameroon: constraints and overview. Integrated Pest Management Reviews 7(3), 191 - 199.

Sonwa, D.J., Weise, S. F., Tchatat, M., Nkongmeneck, B.A., Adesina, A.A., Ndoye, O. and Gockwoski, J. (2001) The role of cocoa agroforests in rural and community forestry in southern Cameroon. RDFN Paper. 25: 1 - 10 . 
Soto-Pinto L., Perfecto I., Caballero-Nieto J. (2002) Shade over coffee: its effects on berry borer, leaf rust and spontaneous herbs in Chiapas, Mexico. Agrofor. Syst. 55, 3745.

Steffan-Dewenter I., Kessler M., Barkmann J, Bos M., Buchori D., Erasmi S., Faust H., Gerold G., Glenk K., Gradstein R.S., Guhardja E., Harteveld M., Hertel D., Höhn P., Kappas M., Köhler S., Leuschner C., Maertens M., Marggraf R., Migge-Kleian S., Mogea J., Pitopang R., Schaefer M., Schwarze S., Sporn G.S., Steingrebe A., Tjitrosoedirdjo S.S., Tjitrosoemito S., Twele A., Weber R., Woltmann L., Zeller M., Tscharntke T. (2007) Tradeoffs between income, biodiversity, and ecosystem functioning during tropical rainforest conversion and agroforestry intensification. PNAS 104: 4973 4978.

Taubert, D., Roesen, R. and Schoemig, E. (2007) Effect of Cocoa and Tea Intake on Blood Pressure: A Meta-analysis. Arch. Intern. Med. 167:626-634.

Vandermeer J. (1995) The ecological basis of alternative agriculture. Ann. Rev. Ecol. System. 26, 201-224.

Way, M.J., \& Khoo, K.C. (1992) Role of ant in pest-management. Annual Review of Entomology, 37, 1335-1355.

Zapfack L., Engwald S., Sonke B., Achoundong G., and Birang M. (2002) The impact of land conversion on plant biodiversity in the forest zone of Cameroon. Biodivers. Conserv. 11: $2047-2061$. 


\section{Publications}

\section{Articles (Submitted)}

Bisseleua, DHB, Gbewonyo, WSK, and Obeng-Ofori, D 2007. Efficacy of crude extracts of Zanthoxylum xanthoxiloides Lam. (Rutaceae) against the cowpea beetle Callosobruchus maculatus (Waip). Submitted to Journal of Applied Entomology

Babin R., Bisseleua D.H.B., Dibog L. and Lumaret J.P. 2007. Rearing method and life tables for the cocoa mirid bug Sahlbergella singularis Haglund (Hemiptera: Miridae). Submitted to Journal of Applied Entomology

Bisseleua, DHB and Vidal, S. 2006. Perception of cocoa agroforest management by farmers after introducing IPM in Farmer's organizations in southern Cameroon. Submitted to Agriculture Ecosystem and Environment

Bisseleua, DHB and Vidal, S. 2007. Women Perception of traditional cocoa forest garden management in southern Cameroon. Submitted to World Development

Bisseleua, DHB and Vidal, S. 2007. Impact of Cocoa farmers' management practices on the incidence of pests and diseases in traditional cocoa forest garden in southern Cameroon. Submitted to Agriculture, Ecosystems and Environment

Bisseleua, DHB and Vidal, S. 2007. Sampling and temporal distribution of Salhbergella singularis (Haglung) (Hemiptera: Miridae) on cocoa. Submitted to Journal of Applied Entomology

Bisseleua, DHB and Vidal, S. 2007. Impact of ants on black pod disease incidence in cocoa plantations in the humid Rainforest area of Cameroon. To be submitted to Basic and Applied Ecology

Bisseleua, DHB and Vidal, S. 2007. Mutually exclusive interactions between a mirid bug and a plant pathogen on Cocoa trees. Submitted to Entomologia Experimentalis Applicata 
Bisseleua, DHB and Vidal, S. 2007. Predatory activity of ants in cocoa plantations under different land-use management: The insurance hypothesis. Submitted to Ecology

Bisseleua, DHB and Vidal, S. 2007. Biodiversity, yield, net income and vegetation structure in traditional cocoa forest gardens in southern Cameroon. Submitted to Ecological Economics.

\section{Articles (Accepted and Published)}

Bisseleua, DHB and Vidal, S. 2007. Plant biodiversity and vegetation structure in traditional cocoa forest gardens in southern Cameroon under different management. Biodiversity and Conservation (Accepted)

Bisseleua, DHB and Vidal, S. 2007. Impact of plant diversity on ants and incidence on pests and disease in cocoa plantations under different land-use management in the rainforest area of Cameroon. In: $15^{\text {th }}$ International Cocoa Research Conference. Proceedings: Cocoa Productivity, Quality, Profitability, Human Health and the Environment. San José, Costa Rica.

Bisseleua, DHB and Vidal, S. 2006. Perception of cocoa agroforest management by farmers after introducing IPM in Farmer's organizations in southern Cameroon. In: $15^{\text {th }}$ International Cocoa Research Conference. Proceedings: Cocoa Productivity, Quality, Profitability, Human Health and the Environment. San José, Costa Rica.

Wang, L.; Bisseleua, DHB; You, M.; Huang, J. and Liu, B. 2006. Population dynamics and functional response of Citrostichus phyllocnistoides (Narayanan) (Hym., Eulophidae) on citrus leaf-miner, Phyllocnistis citrella Stainton (Lep., Phyllocnistidae) in Fuzhou region of south-east China. Journal of Applied Entomology, 130 (2) 96 - 102.

Babin R., Dibog L., Bisseleua DHB. 2004. Mise au point d'une méthode d'élevage de Sahlbergella singularis Hagl. (Hemiptera: Miridae) au laboratoire. Résultats préliminaires des travaux menés au Cameroun. In: 14th International Cocoa Research Conference. 
Accra, Ghana. Proceedings: towards a sustainable cocoa economy - what strategies to this end? - Lagos: Cocoa Producers' Alliance, p. 1333-1341.

Babin R., Dibog L., Bisseleua DHB., Mpe J.M., Amang a Mbang J., Onana C. 2004. Cocoa productivity and quality improvement, a participatory approach: Results from studies on cocoa attractiveness, antixenosis, antibiosis and tolerance towards mirids in Cameroon. In: Cocoa germplasm improvement: global and participatory approaches. Rome: IPGRI.

\section{Posters at Conferences or workshops}

Bisseleua, DHB and Vidal, S. 2007. Mutually exclusive interactions between a mirid bug and a plant pathogen on Cocoa trees. Poster at the $37^{\text {th }}$ Annual Gfö Conference, $10-14$ Septembre, Marburg, Germany

Bisseleua, DHB and Vidal, S. 2007. Predatory activity of ants in cocoa plantations under different land-use management: The insurance hypothesis. Poster at the $37^{\text {th }}$ Annual Gfö Conference, 10 - 14 Septembre, Marburg, Germany

Bisseleua, DHB and Vidal, S. 2006. Impact of ants on black pod disease incidence in cocoa plantations in the humid Rainforest area of Cameroon. 55 Deutsche Pflanzenschutztagung, 25 - 28 September, Goettingen, Germany

Bisseleua, DHB and Vidal, S. 2006. Perception of cocoa agroforest management by farmers after introducing IPM in Farmer's organizations in southern Cameroon. Poster at the $15^{\text {th }}$ International Cocoa Research Conference. Proceedings: Cocoa Productivity, Quality, Profitability, Human Health and the Environment. San José, Costa Rica.

Bisseleua, DHB and Vidal, S. 2004. Participatory technology development to manage cocoa pests in smallholder cocoa plantations in southern Cameroon. Poster at the Entomologentagung, DGAAE, Dresden, Germany 


\section{Acknowledgements}

Many have contributed toward the completion of this study and therefore deserve my gratitude. I gratefully acknowledge my supervisor Prof Dr. Stefan Vidal who responded with keen interest to study cocoa cultivations and problems associated. I am deeply indebted to him for the pieces of advices, contructives criticisms, suggestions and corrections as well as the friendly working environment he has developped.

I am also grateful to the staff of the Laboratory of Entomology, at the "Institut de la Recherche Agricole pour le Développement” (IRAD), Nkolbission, Yaoundé, Cameroon for their tremendous help during field and laboratory works. I thank specifically late M. Djalla, AD. Missoup, M. Mbenoum, O. Victor, J. Nzomo, O. benoît, JC. Mongo, N. Essomo, C. Ngoum Esse, V. koumpia.

My heartfelt goes to Regis Babin and CIRAD, Cameroon for logistic support during field works in Cameroon. I am also grateful to the French Ministy of Cooperation who provided financial assistance through the "Sustainable and Competitive Cocoa Systems" project (FSP regional) during the pilot phase and for field survey.

My gratitude also goes to the cocoa farmer's organizations from Ngomedzap, Bakoa, Obala, Talba and Kedia, the enummarators and field workers.

My utmost gratitude goes to my Colleague Joachim Moeser for our very fruitful discussions and to my family for their deep patience during my stay in Germany and Cameroon.

My gratitude also goes to my friends who stood by me and their moral support during my stay in Germany

My coming to Germany will not have been possible without the support of my colleagues from IRAD, Nkolbisson, specifically Dr Salomon Nyasse, Dr Luc Dibob and Dr Bella Manga.

I also thank the Katholisher Akademischer Auländerdienst (KAAD) and the Katholisher hochschulgemeinde (Khg) for financial support

This work was supported by IPAG (Int. PhD program for Agric Sciences in Geottingen). 


\section{Curriculum Vitae}

Born on 09. September 1971 in Bafang, Cameroon

1997. BSc in Zoology

1998. MSc Animal Biology

- Dissetation title: "Study of the gastro-intestinal helminths of pangolin Manis tricuspis of southern cameroon."

2001. MPhil Entomology

- Dissertation title: "Insecticidal activity of Griffonia simplicifolia (Vahl ex DC.) Baill. (Caesalpiniaceaea) and Zanthoxylum xanthoxyloides Lam.(Rutaceae) against selected insect pests.

2001. Researcher IRAD, Cameroon: Cocoa and coffee program

Since 2003. Ph.D candidate at the Faculty of Agriculture, Department of Crop Sciences, Entomological Section, Georg-August University of Goettingen. 